\title{
Plasmodium spp. em aves silvestres da Fundação Parque Zoológico de São Paulo: identificação de espécie por microscopia e sequenciamento do gene mitocondrial citocromo b
}

Tese apresentada ao Instituto de Medicina Tropical da Universidade de São Paulo para obtenção do título de Doutor em Ciências

Área de concentração: Doenças Tropicais e Saúde Internacional

Orientadora: Prof. Dra. Karin Kirchgatter

São Paulo 
Ficha catalográfica

Preparada pela Biblioteca do Instituto de Medicina Tropical de São Paulo da Universidade de São Paulo (C) Reprodução autorizada pelo autor

Chagas, Carolina Romeiro Fernandes

Plasmodium spp. em aves silvestres da Fundação Parque Zoológico de São Paulo: identificação de espécies por microscopia e sequenciamento do gene mitocondrial citocromo b / Carolina Romeiro Fernandes Chagas. - São Paulo, 2016.

Tese (Doutorado) - Instituto de Medicina Tropical de São Paulo da Universidade de São Paulo para obtenção do título de Doutor em Ciências.

Área de concentração: Doenças Tropicais e Saúde Internacional

Orientadora: Karin Kirchgatter

Descritores: 1. MALÁRIA. 2. PLASMODIUM. 3. AVES. 4. PARASITOLOGIA VETERINÁRIA. 5. ZOOLÓGICOS. 6. DIAGNÓSTICO.

USP/IMTSP/BIB-08/2016. 
Dedico este trabalho aos meus pais, Pedro e Lúcia, que sempre me apoiaram incondicionalmente durante toda a minha trajetória; à minha irmã, que sempre esteve ao meu lado; ao Luiz, pelo apoio, paciência, compreensão e companheirismo nos momentos mais difíceis. 


\section{Agradecimentos}

À Profa. Dra. Karin Kirchgatter pela orientação, carinho, amizade, puxões de orelha e conhecimento dividido durante todo o processo e que apesar das minhas teimosias sempre teve a paciência necessária para me mostrar o melhor caminho.

À Msc Lilian Guimarães de Oliveira e à bióloga Eliana Monteiro, pelo constante apoio e auxílio em todas as atividades de bancada e por me ensinarem os mistérios da biologia molecular. Vocês foram essenciais para que este trabalho acontecesse.

À Dra. Regiane Menezes e bióloga Rose Simões, pelo apoio na identificação dos mosquitos coletados durante o projeto. Essa parte foi essencial para o enriquecimento e irá proporcionar dados muito importantes para a continuidade deste trabalho.

Às biólogas Fabiana de Sousa e Yelina Brito pelo auxílio no trabalho de campo para captura dos mosquitos.

À Fundação Parque Zoológico de São Paulo pela oportunidade, confiança em meu trabalho e oportunidade de trabalhar com esse extraordinário material.

Aos biólogos, "passarinhólogos" e amigos Fernanda Junqueira Vaz Guida, Daniel Perella e Michele Viana, por me socorrerem com as minhas dúvidas sobre cada espécie de ave que apareceu no meu caminho, e por terem me cedido algumas amostras que contribuíram para o enriquecimento dos resultados obtidos.

Ao Dr. Gediminas Valkiūnas, por todo auxílio e apoio durante todos esses anos, pela paciência em transmitir um pouco de seu vasto conhecimento com esse grupo tão encantador de parasitas.

Ao Dr. Dimitar Drimitrov, Dr. Vaidas Palinauskas e Msc. Mikas Ilgūnas, pela troca de ideias, por terem me recebido tão bem em uma terra tão distante de casa e por me fazerem enxergar com mais clareza a importância deste trabalho.

Ao Prof. Dr. Cláudio Marinho e à bióloga Érika Machado, por terem possibilitado a utilização do microscópio para documentação das imagens deste trabalho.

À Dra. Stéfanie Vanessa dos Santos, por ter cedido tão generosamente amostras ao projeto.

Às colegas e biólogas Paula Andrea Borges Salgado e Dra. Patrícia Locosque Ramos, pelo constante apoio técnico e incentivo durante esses anos.

Às secretárias Denise Martins Sanches e Cecília Gregório, pelo auxílio com tantas fichas de animais.

À Msc Priscila Thihara pelo auxílio com algumas análises filogenéticas, me fazendo entender um pouco mais a respeito desse mundo, desafiador e encantador. 
Ao Dr. Expedito Luna, pelo apoio estatístico dado a este trabalho.

À amiga querida Dra. Sandra Helena Ramiro Correa, por me dar apoio incondicional, acreditar em mim e me incentivar a melhor e a fazer melhor sempre.

Às grandes amigas Ana Paula Urbaneja do Valle e Thais Garcia Melo, pelas palavras de incentivo e apoio durante esse caminho.

Às amigas Amanda Moraes e Mariana Nery pelo constante apoio, dicas de descontração, relaxamento e reflexões de vida, graças a vocês essa jornada foi mais suave.

À Fundação de Amparo à Pesquisa do Estado de São Paulo (FAPESP) pelo auxílio à pesquisa (2012/51427-1) que materializou a realização desta ideia.

E a todos que contribuíram direta ou indiretamente para a realização deste projeto. 
Troquei sonhos por objetivos. Eles são mais compactos, ocupam menos espaço e dão mais certo.

Martha Medeiros 


\section{RESUMO}

CHAGAS, CRF. Plasmodium spp. em aves silvestres na Fundação Parque Zoológico de São Paulo: identificação de espécies por microscopia e amplificação do gene mitocondrial citocromo b (tese). São Paulo: Instituto de Medicina Tropical de São Paulo da Universidade de São Paulo; 2016.

O papel dos Zoológicos nos programas de conservação aumentou significantemente nas últimas décadas e a manutenção da saúde dos animais cativos é essencial para garantir o sucesso desses programas. Entretanto, aves mantidas em zoos sofrem de infecções por parasitas, principalmente hemosporídeos, e podem perecer em quase todo o mundo. Estudos para determinar a ocorrência e diversidade desses parasitas, com o objetivo de entender melhor sua influência na condição física das aves em cativeiro, são necessários. Em um estudo de quase quatro anos, nós investigamos a positividade de Plasmodium spp. e Haemoproteus spp. nas aves cativas do Parque Zoológico de São Paulo, o maior zoológico da América Latina e o quarto do mundo. Métodos moleculares e morfológicos foram usados para detectar e identificar esses parasitas. A positividade geral de hemosporídeos nos indivíduos examinados foi $12,6 \%$. Os parasitas foram detectados, sobretudo, através do diagnóstico molecular, indicando que muitas espécies podem abrigar infecções subclínicas. Em um estudo amplo, nós testamos animais de 17 Ordens, 29 Famílias, e 122 espécies, detectando indivíduos positivos em $64,7 \%, 48,3 \%$ e 27\%, respectivamente. Aves da Família Anatidae foram as mais frequentemente infectadas. As infecções com parasitas do gênero Plasmodium foram predominantes quando comparadas aquelas com parasitas do gênero Haemoproteus. No total, 14 linhagens de cytb de Plasmodium spp., incluindo $P$. nucleophilum e $P$. elongatum, e 2 linhagens de cytb de Haemoproteus spp., foram registradas. Dessas linhagens, 8 foram descritas pela primeira vez. Uma dessas linhagens foi notavelmente generalista quanto às espécies hospedeiras, enquanto outras se restringiram a parasitar espécies de uma mesma Família. Estes resultados mostram que entre os animais cativos dos zoos, além dos pinguins, existem várias espécies em risco de contrair malária. A presença de Haemosporida pode ser difícil de eliminar, mas é possível reduzir a taxa de infecção tratando os animais positivos, enquanto os mantêm em instalações livres de mosquitos. Protocolos de quarentena precisam ser utilizados se o animal for transferido entre instituições. O presente estudo é o primeiro inquérito de hemosporídeos realizado em 
aves cativas de diferentes Ordens, e enfatiza a necessidade de incluir, na gestão e criação desses animais no cativeiro, práticas para o controle desses parasitas.

Descritores: Malária. Plasmodium. Aves. Parasitologia Veterinária. Zoológicos. Diagnóstico. 


\begin{abstract}
CHAGAS, CRF. Plasmodium spp. in wild birds in São Paulo Zoo: identification with microscopy and amplification of mithocondrial cytochrome b gene (thesis). São Paulo: Instituto de Medicina Tropical de São Paulo da Universidade de São Paulo; 2016.
\end{abstract}

The role of Zoos in conservation programs has increased significantly in last decades and maintenance of the health of captive animals is essential to guarantee the success of these programs. However, birds kept in zoos suffer from infections by parasites, mainly haemosporidians, and can perish almost everywhere in the world. Studies to determine the occurrence and diversity of these parasites, aiming to better understand its influence in the fitness of the captive birds, are necessary. In a study over four years, we investigated the positivity of Plasmodium spp. and Haemoproteus spp. in the captive birds from the São Paulo Zoo, the largest zoo in Latin America and the fourth in the world. Molecular and morphological methods were used for detecting and identifying these parasites. The overall positivity of haemosporidians in the examined birds was $12.6 \%$. Parasites were mostly detected by the molecular diagnosis, indicating that many bird species may harbour subclinical infections. In a very wide study, we tested animals from 17 Orders, 29 Families, and 122 different species, detecting positive individuals in $64.7 \%, 48.3 \%$ and $27 \%$, respectively. Birds from the Anatidae Family were the most commonly infected animals. Infections with parasites of the genus Plasmodium were predominant when compared to those of the genus Haemoproteus. In total, 14 cytb lineages of Plasmodium spp., including $P$. nucleophilum and P. elongatum, and 2 cytb lineages of Haemoproteus spp., were recorded in this study. From these lineages, 8 were described for the first time. One of these lineages was markedly generalist regarding the host species while others infected just species within the same Family. These results show that among the captive animals in the zoos, besides the penguins, there are many species at risk of acquiring malaria. The presence of Haemosporida could be difficult to eliminate, but it is possible to reduce the infection rate by treating the positive animals, while keeping them in facilities free from mosquitoes. Protocols of quarantine must be implemented whenever an animal is transferred between institutions. The present study is the first survey of haemosporidians carried out with captive birds from 
different Orders, and emphasizes the necessity of applying, in management and husbandry of animals in captivity, practices to control these parasites.

Descriptors: Malaria. Plasmodium. Birds. Veterinary Parasitology. Zoos. Diagnosis. 


\section{LISTA DE ILUSTRAÇÕES}

Figura 1 - Ciclo de vida de Plasmodium spp................................................... 26

Figura 2 - $\quad$ Representação da dinâmica de parasitemia para Plasmodium spp.... 27

Figura 3 - $\quad$ Ciclo de vida de Haemoproteus spp............................................. 31

Figura 4 - $\quad$ Mapa de localização do PEFI e da FPZSP...................................... 36

Figura 5 - Exemplos de coleta de sangue em veia jugular e em veia braquial................................................................................... 38

Figura 6 - Representação esquemática dos fragmentos amplificados para o gene $c y t b$.

Figura 7 - Pontos de coleta de Culicidae.......................................................... 43

Figura 8 - $\quad$ Armadilha CDC Mini UV ......................................................... 43

Figura 9 - Fotomicrografia de Plasmodium sp. linhagem NYCNYC01 visualizado em esfregaço sanguíneo obtido de Cygnus atratus.........

Figura 10 - Fotomicrografia de $P$. nucleophilum visualizado em esfregaço sanguíneo obtido de Alopochen aegyptiacus................................... 58

Figura 11 - Fotomicrografia de Plasmodium sp. linhagem DENVID01 visualizado em esfregaços sanguíneos obtidos de Cygnus atratus e de Pavo muticus.

Figura 12 - Fotomicrografia de $P$. elongatum visualizado em esfregaço sanguíneo obtido de Cygnus atratus.

Figura 13 - Fotomicrografia de Plasmodium sp. linhagem RAMVIT01 visualizado em esfregaço sanguíneo obtido de Ramphastos toco.....

Figura 14 - Fotomicrografia de Plasmodium sp. linhagem ARACAJ01 visualizado em esfregaço sanguíneo obtido de Aramides cajanea.....

Figura 15 - Fotomicrografia de Plasmodium sp. linhagem SALAT01 visualizado em esfregaço sanguíneo obtido de Saltator atricolis.....

Figura 16- Fotomicrografia de Plasmodium sp. linhagem CERNOV01 visualizado em esfregaço sanguíneo obtido de Cereopsis novahollandiae. 
Figura 17 - Filogenia bayesiana das linhagens do gene citb das espécies de Plasmodium encontradas.

Figura 18 - Rede de haplótipos segundo a Ordem dos hospedeiros

Figura 19 - Rede de haplótipos segundo a localização geográfica, por continente, de ocorrência das linhagens

Figura 20 - Fotomicrografia de H. ortalidum linhagem EUDRUB01 visualizado em esfregaço sanguíneo obtido de Eudocimus ruber.

Figura 21 - Fotomicrografia de Haemoproteus sp. linhagem PENOBS01 visualizado em esfregaço sanguíneo obtido de Penelope obscura.....

Figura 22 - Filogenia bayesiana das linhagens do gene citocromo b das espécies de Haemoproteus encontradas.

Figura 23 - Demonstração dos pontos de LPI na área da FPZSP

Gráfico 1 - Distribuição dos Indivíduos amostrados segundo Ordem.

Gráfico 2 - Distribuição dos Indivíduos amostrados segundo Família

Gráfico 3 - Distribuição dos indivíduos positivos para Plasmodium/Haemoproteus segundo Ordem...

Gráfico 4 - Distribuição dos indivíduos positivos para Plasmodium/Haemoproteus segundo Família.

Gráfico 5 - Prevalência das linhagens encontradas nos animais cativos

Gráfico 6 - Diversidade de linhagens encontradas por Ordem

Gráfico 7 - Diversidade de linhagens encontradas por Família

Gráfico 8 - Distribuição sazonal de animais amostrados e positivos

Gráfico 9 - Ocorrência dos gêneros de mosquitos da família Culicidae coletados na FPZSP

Gráfico 10 - Distribuição dos mosquitos Culicidae coletados na FPZSP por ponto de coleta.

Gráfico 11 - Riqueza de gêneros de Culicidae encontrada na FPZSP segundo ponto de coleta.

Gráfico 12 - Diversidade de fontes de repasto sanguíneo por recinto amostrado. 


\section{LISTA DE TABELAS}

Tabela 1 - Pontos de colocação de armadilhas e suas coordenadas

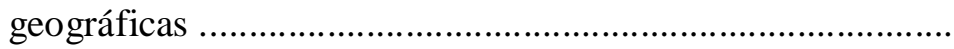

Tabela 2 - Aves com resultados positivos no PCR para Plasmodium/Haemoproteus e suas respectivas linhagens .............. 51

Tabela 3 - $\quad$ Animais adultos com quatro ou mais coletas no estudo e presença

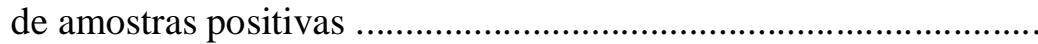

Tabela 4 - Composição das espécies de mosquitos Culicidae coletados com armadilha $\mathrm{CDC}(\mathrm{s})$ iscadas com $\mathrm{CO}_{2}$ e aspiração durante o período de estudo em recintos do Parque Zoológico de São Paulo. 76

Tabela 5 - Fonte de repasto sanguíneo identificadas nos mosquitos ingurgitados 


\section{LISTA DE ABREVIATURAS E SIGLAS}

$\begin{array}{ll}\text { BA } & \text { Bosque das Aves } \\ \text { CIENTEC } & \text { Instituto de Ciência e Tecnologia } \\ \text { Cytb } & \text { Citocromo b } \\ \text { DNA } & \text { Ácido desoxirribonucleico } \\ \text { DV } & \text { Divisão de Veterinária } \\ \text { FM } & \text { Recinto dos Flamingos } \\ \text { FPZSP } & \text { Fundação Parque Zoológico de São Paulo } \\ \text { IB } & \text { Instituto de Botânica } \\ \text { L70 } & \text { Lago 70 } \\ \text { MalAvi } & \text { Avian Malaria Initiative } \\ \text { PCR } & \text { Reação em cadeia da polimerase } \\ \text { PEFI } & \text { Parque Estadual das Fontes do Ipiranga } \\ \text { PO } & \text { Ponte } \\ \text { R113 } & \text { Recinto 113 } \\ \text { R61 } & \text { Recinto 61 } \\ \text { R69 } & \text { Recinto 69 } \\ \text { EX } & \text { Recinto Extra } \\ \text { ZS } & \text { Zôo Safari }\end{array}$




\section{SUMÁRIO}

Cativeiro ................................................................... 17

Estudos com Haemosporida .......................................... 18

Plasmodium spp. ..................................................... 21

Ciclo de vida de Plasmodium ....................................... 23

Haemoproteus spp. ................................................... 27

Ciclo de vida de Haemoproteus ................................... 28

Taxonomia e Diagnóstico ............................................. 31

OBJETIVOS _........................................................... 35

Objetivo Geral ..................................................... 35

Objetivos Específicos ................................................. 35

MATERIAL E MÉTODOS ........................................ 36

Local de Estudo .......................................................... 36

Coleta de amostras: sangue e esfregaços sanguíneos ...... 37

Análise microscópica dos esfregaços sanguíneos ............ 38

Extração de DNA genômico e amplificação do gene 39 mitocondrial $c y t b$ de Haemosporida Sequenciamento e análise das sequencias ..................... 40

Sazonalidade ............................................................... 41

Determinação do local provável da infecção e captura de mosquitos da Família Culicidae .................................... 42 Extração de gDNA do sangue de mosquitos ingurgitados e identificação do repasto sanguíneo .......... 44 Análise estatística .................................................... 45

Aspectos Éticos ........................................................ 45

RESULTADOS ...................................................... 46

Perfil dos animais amostrados .................................... 46

Perfil dos animais positivos .......................................... 48

Resultados morfológicos e moleculares ........................ 54

Linhagens de Plasmodium spp. .................................. 57

Linhagens de Haemoproteus spp. ............................... 67 
Sazonalidade ….................................................. 70

4.5 Acompanhamento longitudinal ................................... 70

4.6 Levantamento de Culicidae ........................................... 73

4.7 Fontes de Repasto Sanguíneo ......................................... 78

$5 \quad$ DISCUSS ÃO _............................................... 81

$6 \quad$ CONCLUSÕES _..................................................... 97

$7 \quad$ CONSIDERAÇÕES FINAIS _................................... 98

8 REFERÊNCIAS BIBLIOGRÁFICAS ......................... 199

APÊNDICE A Aves amostradas nesse estudo, amostras com resultado 114 positivo por PCR para Plasmodium/Haemoproteus, distribuição geográfica e status de ameaça.

APÊNDICE B Artigo publicado no Int J Parasitol Parasites Wildl. 125 "Plasmodium (Novyella) nucleophilum from an Egyptian Goose in São Paulo Zoo, Brazil: microscopic confirmation and molecular characterization". Chagas et al., 2013.

APÊNDICE C Artigo publicado no Parasitol Res. "Hemosporidian parasites of free-living birds in the São Paulo Zoo, Brazil". Chagas et al., 2016.

APÊNDICE D Artigo em preparação para submissão ao Malar J. 143 "DIVERSITY AND DISTRIBUTION OF AVIAN MALARIA AND RELATED HAEMOSPORIDIAN PARASITES IN CAPTIVE BIRDS FROM A BRAZILIAN MEGALOPOLIS".

ANEXO A Autorização para atividades com finalidade científica SISBIO Número: 34605-6

ANEXO B Parecer Comitê de Pesquisa do Instituto de Medicina 152 Tropical (CEP/193).

ANEXO C Parecer Comitê de Pesquisa do Instituto de Medicina 154 Tropical (CEP/294). 


\section{INTRODUÇÃO E REVISÃO DE LITERATURA}

\subsection{Cativeiro}

Desde o Egito Antigo (2500 a.C.) o ser humano tem mantido animais silvestres em coleções. No sec. XVIII, quando a posse desses animais representava status e poder, existiam coleções privadas, não abertas ao público, onde a recreação era a principal finalidade ${ }^{1}$. Essas coleções foram aos poucos se transformando em zoológicos, cujo papel principal foi se alterando ao longo dos anos, sendo que, a partir de 1960, a preocupação com conservação foi ganhando mais espaço. A contribuição dos zoológicos para a conservação da vida selvagem através de pesquisa científica, educação ambiental, melhorias em manejo e bem-estar animal ganhou o espaço que antes era reservado ao lazer e ao entretenimento da população ${ }^{1-3}$. Atualmente, muitos zoológicos ao redor do mundo estão participando ativamente de programas de conservação in situ e ex situ, patrocinando expedições para estudo de espécies em seu habitat natural e atuando como reserva genética de muitas espécies ameaçadas $^{1}$.

O ambiente cativo também oferece aos animais condições especiais, não encontradas na natureza, como comida disponível durante o ano todo, proteção contra predadores e cuidados veterinários, interferindo diretamente na sobrevivência a diferentes enfermidades ${ }^{4}$. Embora muitas doenças em animais silvestres, incluindo as zoonóticas, têm sido alvo de investigações científicas, estudos sobre a diversidade e a ecologia de parasitas na vida selvagem permanecem negligenciados, com muitas perguntas a serem respondidas ${ }^{5-6}$. Os parasitas também fazem parte da biodiversidade e desempenham um importante papel nas comunidades em que estão inseridos, atuando no controle populacional através da influência direta nos nascimentos e longevidade dos animais, além de afetar as interações competitivas entre os hospedeiros ${ }^{5-6}$.

Doenças parasitárias podem ser muito comuns em cativeiro e oferecer um grande risco, uma vez que muitas podem ser facilmente transmitidas, levando 
inclusive à morte ${ }^{3,7-8}$. A alta densidade populacional, cenário comumente encontrado em ambiente cativo, pode ser agravada pela convivência de espécies de diferentes regiões geográficas, e a consequente exposição a parasitas que não coevoluíram com aquele hospedeiro e que, portanto, não apresenta um sistema imune competente para combater a infecção ${ }^{9}$, resultando em doenças parasitárias graves e até mesmo letais ${ }^{2-}$ 3 .

Um grupo de parasitas de distribuição cosmopolita muito importante é a Ordem Haemosporida (Apicomplexa), composta pelas Famílias Plasmodiidae, Haemoproteidae, Leucocytozoidae e Garniidae, com os gêneros Plasmodium, Haemoproteus, Leucocytozoon e Fallisia, respectivamente ${ }^{10}$. Esses parasitas possuem ciclo heteroxênico obrigatório, sendo transmitidos por insetos hematófagos da Ordem Diptera de diversas Famílias ${ }^{10}$. Plasmodium é o único com merogonia eritrocitária, enquanto que em Haemoproteus e Leucocytozoon ocorre a formação de megalomerontes teciduais. Fallisia foi relatado até hoje somente na região tropical e é encontrado infectando trombócitos e raramente leucócitos (linfócitos e monócitos). A presença de hemozoína, ou pigmento malárico, é registrada somente em Plasmodium e Haemoproteus ${ }^{10}$.

\subsection{Estudos com Haemosporida}

Hipócrates, conhecido como o pai da medicina, já observava em seus pacientes episódios de febre intermitentes, e na época essa doença era conhecida como paludismo, impaludismo ou febre palustre ${ }^{11}$. Somente no século XIX é que a doença passou a ser chamada de malária, devido à associação que alguns cientistas italianos fizeram, uma vez que eles acreditavam que a doença era causada por vapores nocivos exalados dos pântanos, chamando-a de "mal-aria", ou "mau ar"11. Somente em 1880, o médico francês Charles Louis Alphonse Laveran observou organismos em movimento ao examinar o sangue fresco de um paciente com malária. Posteriormente, em 1884, Gerhardt confirmou se tratar de uma hemoparasitose, através da transfusão de sangue infectado para um paciente não 
infectado $^{11}$. O nome Plasmodium surgiu somente em 1884, dado por Alphonse Laveran $^{12}$.

Por volta de 1885 , o russo Vassily Danilewsky verificou a presença de estruturas semelhantes ao protozoário descoberto por Laveran em sangue de anfíbios, aves e répteis ${ }^{12}$. Após diversos estudos, percebeu que os parasitas de aves eram muito parecidos aos da malária humana, e passou a estudá-los na tentativa de melhor compreender a enfermidade humana, comprovando a ocorrência de sinais clínicos como anemia aguda, hepatomegalia, esplenomegalia e acúmulo de pigmento nesses órgãos em animais infectados ${ }^{12}$. Percebeu também que os parasitas eram encontrados no sangue sazonalmente, durante os meses de verão ${ }^{12}$.

Entre 1889 e 1892, os cientistas italianos Giovanni Battista Grassi e Raimondo Feletti estabeleceram o gênero Haemamoeba e descreveram $H$. relicta e H. subpraecox infectando aves e $H$. vivax e Laverania malariae infectando seres humanos $^{12}$. Nesse mesmo período, Walther Krause estabeleu o gênero Haemoproteus para descrever parasitas intracelulares, os mesmos descritos anteriormente por Danilewsky, sendo eles: H. danilewskii, H. columbae e H. passeris ${ }^{12}$.

Em 1898, Ronald Ross, através de infecções experimentais entre aves infectadas por Plasmodium e não infectadas e utilizando mosquitos do gênero Culex, conseguiu provar que a malária era transmitida através de um vetor invertebrado ${ }^{11-13}$. Após a descoberta de que Plasmodium infectava roedor, animal com fisiologia similar a dos seres humanos, com facilidade de manejo e manutenção em pequenos ambientes, esses substituíram as aves como modelos experimentais nos estudos da malária humana ${ }^{14}$.

Os estudos com Haemosporida em aves continuaram com os profissionais preocupados em compreender as relações ecológicas e evolutivas entre esses parasitas e hospedeiros. Apesar disso, muitos estudos acabaram voltados para os vetores da malária humana ${ }^{13}$. O termo malária é genérico e vem sendo utilizado erroneamente para descrever não apenas infecções por Plasmodium, mas também infecções por outros hemosporídeos (Haemoproteus, Leucocytozoon e Fallisia) devido à proximidade taxonômica e similaridades patológicas e epidemiológicas ${ }^{10,15}$.

Com relação aos hemosporídeos, a grande maioria dos trabalhos publicados foi realizada em regiões de clima temperado, com a avifauna nativa e migrante ${ }^{16-28}$. 
Apesar das dificuldades em se amostrar animais nas regiões tropical e subtropical, devido à grande diversidade de hospedeiros e a dificuldade de acesso às aves, recentemente vários estudos têm sido realizados nessas localidades ${ }^{29-34}$, inclusive no Brasil $^{35-44}$. No Estado de São Paulo, dois grandes levantamentos foram realizados na década de $80^{45-46}$. Recentemente, outros estudos têm mostrado a presença desses parasitas em aves cativas e de vida livre no Estado ${ }^{47-48}$.

A distribuição de hemosporídeos é um reflexo da distribuição de vetores competentes para a veiculação desses parasitas. Locais com maiores temperaturas e com maiores índices de pluviosidade albergam uma maior quantidade de espécies de Diptera. No entanto, para que o mosquito se infecte após a realização do repasto sanguíneo em uma ave infectada, é necessário que o ciclo de vida do parasita se complete, e para isso, há necessidade de condições ambientais adequadas, tal como temperatura. Para Plasmodium a temperatura ótima varia entre $20^{\circ} \mathrm{C}$ e $30^{\circ} \mathrm{C}$ e o mosquito raramente irá se infectar se ficar exposto a temperaturas abaixo dos $13^{\circ} \mathrm{C}$ logo após o repasto sanguíneo. Pode ainda ocorrer deterioração de oocistos se estes forem submetidos a temperaturas abaixo de $4^{\circ} \mathrm{C}$ por muito tempo. Além disso, em baixas temperaturas os vetores têm dificuldade de sobreviver, e, portanto, as altas temperaturas das regiões tropicais favorecem o desenvolvimento tanto dos vetores quanto dos parasitas, mantendo a transmissão constante durante praticamente todo o ano $26,50-51$.

Quase metade das espécies de Aves descritas já foi estudada quanto à presença de hemosporídeos, sendo que Plasmodium spp. foi detectado em torno de $30 \%$ delas e Haemoproteus spp. em $50 \%{ }^{10}$. Apesar do aumento do número de estudos, ainda há uma lacuna a ser preenchida, principalmente na região Tropical, em ambientes cativos e em espécies $\operatorname{raras}^{10}$. Além disso, a grande maioria dos animais positivos pertence à Ordem Passeriformes, correspondendo a $87 \%$ dos registros que constam no MalAvi, provavelmente devido à facilidade em se amostrar esse grupo ${ }^{29}$.

O MalAvi (Avian Malaria Initiative) é um banco de dados público para parasitas hemosporídeos de aves disponibilizado online (http://mbioserv2.mbioekol.lu.se/Malavi/index.html) e criado para centralizar e padronizar as informações destes parasitas, em relação às sequências gênicas utilizadas, nomenclatura das linhagens, informações de hospedeiros e localização geográfica ${ }^{52}$. 
Ele apresenta várias tabelas. A tabela principal contém todas as linhagens únicas nomeadas pelo acrônimo do nome do hospedeiro no qual a linhagem foi primeiramente identificada e o número da linhagem. Outras tabelas incluem sequências e informações de parasitas por hospedeiro, com localização geográfica e referência. O MalAvi possui ainda uma ferramenta de BLAST para encontrar correspondências entre as mais de 3000 linhagens atualmente disponíveis no banco de dados. Por fim, a tabela MorphoSpecies apresenta os nomes científicos para as linhagens que foram morfologicamente identificadas por microscopia. O banco de dados é atualizado constantemente pela submissão das informações geradas pelos grupos que trabalham na área. Vários estudos já utilizam o MalAvi como referência em suas análises ${ }^{29,}$ 39-41, 48-49, 53-56.

\subsection{Plasmodium spp.}

Há registros de Plasmodium infectando aves, répteis, anfíbios e mamíferos, com 67 espécies já descritas em aves ${ }^{57}$, número que aumenta a cada ano, principalmente nessa classe de animais ${ }^{58}$. Há cinco subgêneros de Plasmodium descritos para a Classe Aves, sendo: Haemamoeba, Giovannolaia, Novyella, Bennetinia e Huffia ${ }^{10}$. Esses subgêneros são separados devido a diferenças morfológicas presentes na fase eritrocítica do hospedeiro vertebrado, como formato do gametócito, quantidade de merozoítos formados e capacidade de alterar as células infectadas ${ }^{10}$. As espécies com maior distribuição geográfica são Plasmodium (Haemamoeba) relictum e Plasmodium (Giovannolaia) circumflexum e há maior diversidade de espécies em Galliformes, Columbiformes e Passeriformes ${ }^{10,59}$.

Plasmodium é encontrado em praticamente todo o globo, com exceção da Antártica, devido à ausência de seus vetores. Esses são insetos da Família Culicidae, principalmente os do gênero Culex, mas espécies de outros gêneros também podem estar envolvidas como Aedeomyia, Aedes, Anopheles, Armigeres, Culiseta, Coquillettidia, Lutzia, Mansonia, Verralina e Wyeomyia ${ }^{10,13,53,60-62,64}$. A maioria dos gêneros foi testada experimentalmente para a transmissão de Plasmodium, mas 
poucos provaram sua transmissão natural. $P$. relictum, uma das espécies mais bem conhecidas, consegue completar o seu ciclo em 16 espécies diferentes de Culicidae. Entretanto, acredita-se que o número de vetores capazes de transmitir Plasmodium seja muito maior, pois muitos vetores ainda são desconhecidos ${ }^{10,12}$.

Algumas espécies de Plasmodium são generalistas, enquanto que outras são espécie-específicas, tanto no que diz respeito às aves quanto aos vetores ${ }^{12,45}$. Essa característica viabiliza a realização de estudos com infecções experimentais e uma melhor compreensão do ciclo e da patologia desses parasitas ${ }^{10}$.

A patogenicidade de Plasmodium varia de moderada a severa, conforme a espécie hospedeira e entre os indivíduos, devido às diferenças no sistema imunológico, sendo particularmente virulento para os animais com sistema imune imaturo $^{50,66}$. Diversas espécies de pinguins (Sphenisciformes) são muito sensíveis às infecções por Plasmodium. A ocorrência de surtos com altas taxas de mortalidade é comum em animais cativos e em centros de reabilitação ${ }^{67,47,44}$. Outro exemplo de sensibilidade frente à infecção por este parasita ocorreu no Havaí, quando $P$. relictum foi introduzido no arquipélago, juntamente com seu vetor C. quinquefasciatus, muitos animais morreram, reduzindo drasticamente o número de indivíduos de algumas espécies, como o "honeycreeper" (Família Drepanidae) ${ }^{68-69}$.

Algumas espécies de Plasmodium podem ser muito patogênicas durante a fase aguda da infecção, como é o caso de $P$. relictum, $P$. gallinaceum, $P$. juxtanucleare e $P$. elongatum ${ }^{60}$. Os principais sintomas incluem anemia, letargia, anorexia, penas arrepiadas, diminuição do hematócrito em até 50\%, e em alguns casos fezes esverdeadas, diarreia, paralisia parcial ou total, edema das patas e sinais neurológicos ${ }^{60}$. Há também alterações de parâmetros bioquímicos, como a diminuição da albumina plasmática e o aumento de $\gamma$-globulinas, proteína plasmática, AST, GGT e GLDH. Além de alteração significativa do hematócrito, pode ocorrer também leucocitose por linfocitose ${ }^{10,70-71}$. Comprometimento hepático e esplênico acentuado é descrito em praticamente todas as infecções, com aumento e descoloração desses órgãos e acúmulo de hemozoína nos macrófagos, embora outros órgãos possam também ser afetados ${ }^{60}$.

Muitos levantamentos de hemosporídeos em aves possuíam um desenho experimental com animais silvestres que favorecia a captura e consequente 
amostragem de animais em fase crônica de infecção, levando muitos pesquisadores a acreditar que esses parasitas, principalmente Plasmodium, dificilmente causavam sinais clínicos ${ }^{50}$. Entretanto, hoje se sabe que os sintomas vão de moderados a graves, geralmente com comprometimento da saúde do animal, principalmente durante a fase aguda, podendo culminar com óbito ${ }^{60}$. O comprometimento da reprodução tem sido documentado tanto em criações comerciais ${ }^{10}$ quanto em animais silvestres $^{9,73}$, afetando a qualidade dos ovos postos e o desenvolvimento do filhote.

Há registros de Plasmodium em aves de alguns zoológicos pelo mundo. No Japão, P. juxtanucleare foi o responsável pela morte de faisões (Crossoptilon crossoptilon $)^{74}$. No Brasil, Plasmodium sp. foi encontrado em $36 \%$ dos psitacídeos cativos de três diferentes zoológicos ${ }^{75}$ e P. nucleophilum foi encontrado em um exemplar de ganso-do-Egito (Alopochen aegyptiacus) que veio a óbito no Zoológico de São Paulo ${ }^{48}$. Plasmodium sp. foi encontrado em flamingos-chilenos no zoológico de Chicago, EUA ${ }^{76}$, em outros 6 animais em um zoológico do Texas, também nos Estados Unidos ${ }^{77}$ e em rapinantes na Itália ${ }^{28}$. P. relictum, P. elongatum, P. tejerai, $P$. cathemerium, $P$. nucleophilum e $P$. unalis têm sido descritos em pinguins cativos e de centros de reabilitação no Brasil e pelo mundo ${ }^{47,78}$.

\subsubsection{Ciclo de vida de Plasmodium}

A maioria dos estudos envolvendo o ciclo de vida de Plasmodium foi realizada com o subgênero Haemamoeba, quando esses eram os modelos experimentais da malária humana, sendo extrapolados para os demais ${ }^{10}$. O desenvolvimento do parasita nas aves pode ser dividido basicamente em merogonia exoeritrocítica, merogonia eritrocítica e formação dos gametócitos (Figura 1). A merogonia exoeritrocítica é dividida em primária ou pré-eritrocítica (I e II) e secundária ou pós-eritrocítica (IV). A merogonia exoeritrocítica primária consiste em duas gerações de merontes teciduais, que são chamados de criptozoítos (2 e 3) e metacriptozoítos (5 e 6), respectivamente. A merogonia exoeritrocítica secundária incluem várias gerações de merontes que são chamados de fanerozoítos (13 e 14). 
Plasmodium é o único a realizar merogonia eritrocitária (III) dentre os hemosporídeos ${ }^{10}$.

Os esporozoítos (24), presentes na glândula salivar do vetor, são inoculados nas aves durante a picada e invadem as células endoteliais e mononucleares fagocíticas (1) dando origem à primeira geração de merontes exoeritrocíticos ou criptozoítos (2). Menos de 100 merozoítos (3) são formados e eles ainda não são capazes de infectar os eritrócitos circulantes. Essa fase é conhecida como merogonia exoeritrocítica primária (I). Ocorre então o desenvolvimento dos criptozoítos em metacriptozoítos (4). Esse desenvolvimento ocorre nos macrófagos de diferentes órgãos, principalmente pulmão, baço, fígado e medula óssea, através de reprodução assexuada do parasita (5), liberando grande quantidade de merozoítos (6) e formando a segunda geração de parasitas da merogonia exoeritrocítica primária (II). Nessas duas fases os parasitas possuem morfologia semelhante, mas o número de metacriptozoítos formados é muito maior do que de criptozoítos. Esses merozoítos já são capazes de infectar os eritrócitos circulantes e com a sua liberação se inicia a parasitemia, que ainda é baixa. Esse período é denominado pré-patente e varia de acordo com a espécie de Plasmodium envolvida na infecção. P. relictum leva cerca de 120 horas para que os parasitas possam ser encontrados no sangue. Uma parte dos merozoítos irá infectar outras células teciduais iniciando a merogonia exoeritrocítica secundária (IV). Uma parte dos parasitas que infectarem os eritrócitos circulantes (7) podem se desenvolver em gametócitos (8) ou em merontes (10) e formar novos merozoítos (11). Essa fase do ciclo é conhecida como merogonia eritrocítica (III). Os eritrócitos se rompem liberando os merozoítos que infectarão novos eritrócitos (15) e se desenvolverão em gametócitos (16). Os merozoítos resultantes da merogonia exoeritrocítica secundária (IV) também podem invadir células endoteliais e mononucleares fagocíticas em diversos tecidos (12) e se desenvolvem por reprodução assexuada em fanerozoítos (ou merontes teciduais) (13). Lá permanecem por longos períodos, quando se rompem liberando grande quantidade de merozoítos (14), realizando a manutenção da infecção em fase crônica e a liberação de parasitas na circulação durante as recaídas ${ }^{10}$.

Ao invadir os eritrócitos, os merozoítos passam a ser chamados de trofozoítos (Figura 1: 7, 9, 15), e somente após algum tempo é que a hemozoína, ou pigmento 
malárico, estará visível. Os trofozoítos podem originar merontes eritrocitários e gametócitos. A quantidade de merozoítos presente nos merontes eritrocitários (Figura 1: 10) é uma das características mais importantes na identificação morfológica das espécies ${ }^{10}$.

Uma parte dos merozoítos produzidos na circulação invade as células endoteliais dos capilares de diversos órgãos, incluindo o cérebro, e iniciam a merogonia exoeritrocítica secundária, com a formação dos fanerozoítos (IV). Em geral, a maturação desta fase coincide com o aumento significativo da parasitemia. Os fanerozoítos, juntamente com os merontes exoeritrocíticos (12), produzem os merozoítos que mantêm a parasitemia na fase crônica da infecção, sendo também os responsáveis pelas recaídas ${ }^{10}$.

Rapidamente após a ingestão dos gametócitos pelo vetor durante o repasto sanguíneo se inicia o processo de gametogênese, em que os gametócitos vão assumindo um formato redondo e escapam do interior dos eritrócitos no intestino do vetor (17 e 18). Um dos principais estímulos para que isso ocorra é a mudança nos níveis de oxigênio e dióxido de carbono. O macrogametócito produz macrogametas arredondados (17), enquanto que o microgametócito passa por um processo de exflagelação que dá origem a oito microgametas móveis (18). A fertilização ocorre em ambiente extracelular e o zigoto se transforma em um oocineto de formato arredondado móvel (20). O oocineto penetra através da membrana peritrófica e através da membrana epitelial do intestino. $\mathrm{O}$ oocineto assume forma arredondada e se transforma em oocisto que é circundado por uma espécie de cápsula (22). Durante o processo de desenvolvimento do oocisto, que é chamado de esporogonia, numerosos corpos unicelulares alongados, os esporozoítos, são formados (22). Após a maturação do oocisto (23), os esporozoítos se movem pela hemocele e penetram nas glândulas salivares do vetor (24). Os esporozoítos são as formas infectantes para as aves e são injetados no hospedeiro vertebrado durante o repasto sanguíneo. A temperatura ótima para o desenvolvimento do parasita no vetor pode variar consideravalmente, bem como o tempo para a completa esporogonia. No caso de $P$. relictum em Culex pipiens, a esporogonia é finalizada em sete dias após a ingestão dos gametócitos maduros ${ }^{10}$. 


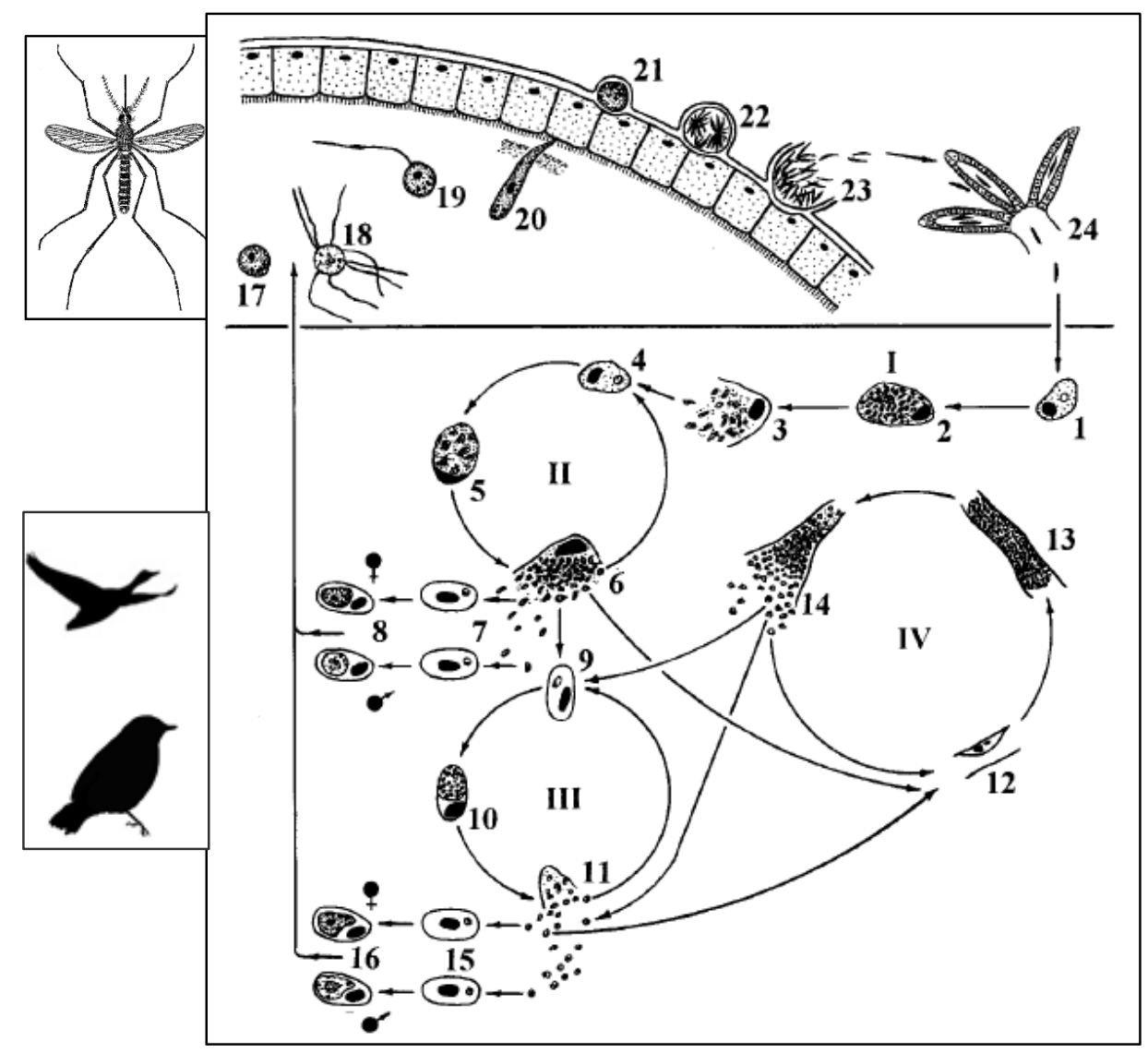

Figura 1 - Ciclo de vida de Plasmodium spp. Ave: 1-16. Vetor: 17-24. I, II merogonia exoeritrocítica primária; III - merogonia eritrocítica; IV merogonia exoeritrocítica secundária; 1 - esporozoítos em células reticuloendoteliais; 2,3 - criptozoítos; 4 - merozoítos em macrófago; 5,6 - metacriptozoítos; 7 - merozoítos nos eritrócitos; 8 - gametócitos; 9 merozoítos nos eritrócitos; 10, 11 - merontes eritrocitários; 12 merozoítos nas células endoteliais dos capilares; 13,14 - fanerozoítos; 15 - merozoítos nos eritrócitos; 16 - gametócitos; 17 - macrogameta; 18 exflagelação dos microgametas; 19 - fertilização dos magrogametas; 20 - oocineto penetrando na membrana peritrófica; 21 - oocistos jovens; 22 , 23 - esporogonia; 24 - esporozoítos na glândula salivar do vetor (adaptado de Valkiūnas, 2005).

Plasmodium possui uma dinâmica de parasitemia muito importante no que se refere a diagnósticos (Figura 2), podendo representar um desafio quando somente esfregaços sanguíneos são utilizados. Um aumento da parasitemia caracteriza a chamada fase aguda ou parasitemia inicial, cuja duração pode variar entre uma e várias semanas, dependendo da espécie, da linhagem do parasita e da espécie 
hospedeira. Se o animal sobreviver a essa fase, inicia-se a fase crônica com a diminuição da parasitemia, podendo atingir níveis indetectáveis. Entretanto, a ave continua infectada com presença do parasita em diferentes tecidos. Caso haja algum comprometimento do sistema imunológico (estresse crônico, outras doenças, período migratório e reprodutivo), a parasitemia pode aumentar, levando a uma recrudescência. Essas parasitemias são secundárias e, em geral, coincidem com o período de nascimento das aves, sendo importantes na transmissão para os animais mais jovens e manutenção do parasita na natureza ${ }^{10}$.

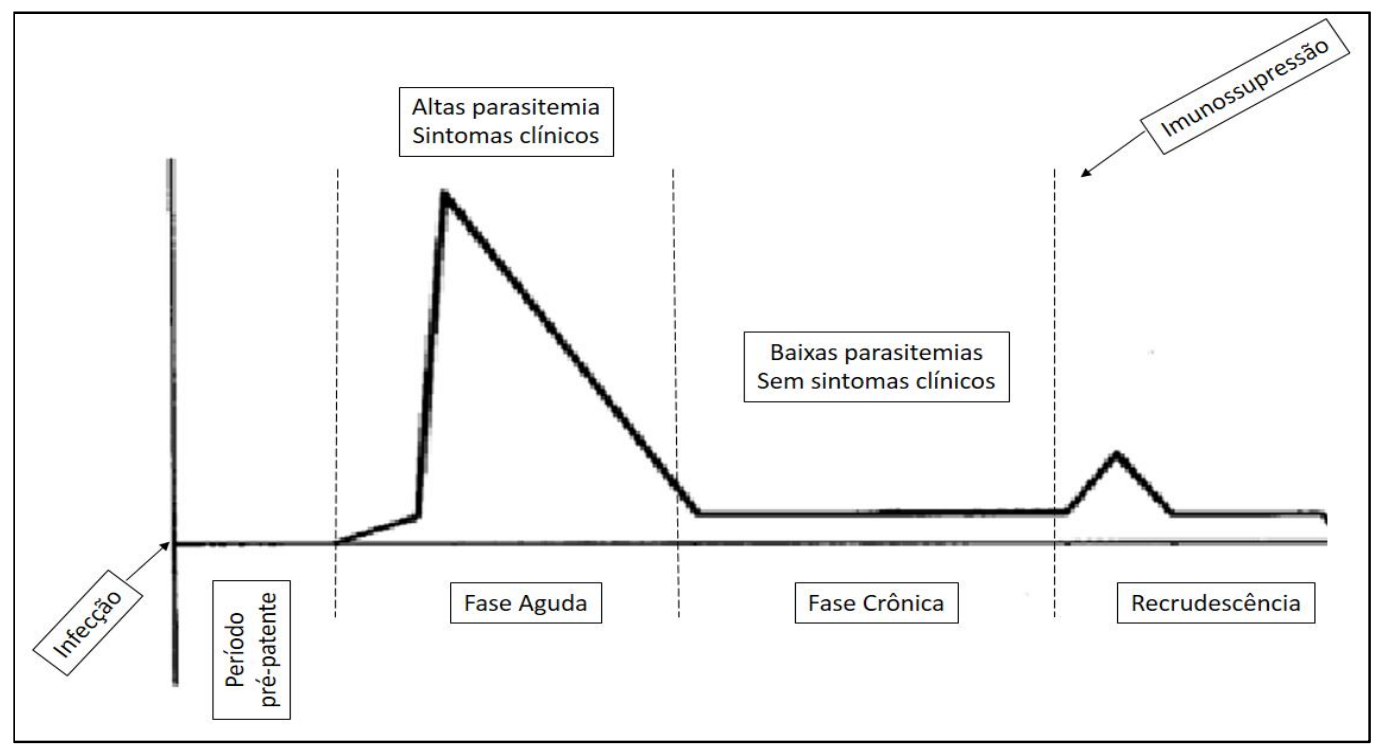

Figura 2 - Representação da dinâmica de parasitemia para Plasmodium spp. (adaptado de Valkiūnas, 2005).

\subsection{Haemoproteus spp.}

Haemoproteus é um gênero com grande diversidade de espécies descritas e ampla distribuição geográfica, com maior abundância em regiões de clima temperado $^{10,52}$. Possui dois subgêneros, Haemoproteus e Parahaemoproteus. O subgênero Haemoproteus é transmitido por moscas da Família Hippoboscidae 
(Diptera), tais como: Pseudolynchia, Ornithomyia, Stilbometopa, Lynchia e Mycolynchia. O subgênero Parahaemoproteus é veiculado por "mosquitos-pólvora" (Culicoides) pertencentes à Família Ceratopogonidae (Diptera) ${ }^{10}$.

Em geral, H. (Haemoproteus) sp. é encontrado infectando aves da Ordem Columbiformes e H. (Parahaemoproteus) sp. infecta as demais Ordens de Aves ${ }^{10}$, sendo este um dos critérios de identificação morfológica utilizados atualmente. Algumas infecções altamente patogênicas têm sido descritas, resultando em desenvolvimento abortivo e morte do hospedeiro ${ }^{79-80}$. Infecções abortivas são caracterizadas pela ausência de gametócitos na circulação, mas é possível encontrar o parasita em diferentes órgãos ${ }^{25}$.

Em Haemoproteus sp. não há merogonia eritrocítica. A merogonia ocorre apenas nas células endoteliais e nos macrófagos e, para certas espécies, também ocorre nos miofibroblastos. Os gametócitos se desenvolvem em eritrócitos maduros, sendo o único estágio de desenvolvimento encontrado na circulação sanguínea. Para este gênero as infecções experimentais são possíveis apenas com a infecção de vetores primeiramente ${ }^{10}$.

Haemoproteus possui baixa patogenicidade e raramente provoca anemia. Os danos causados às aves podem ser mais devido ao comprometimento dos órgãos infectados e pela incapacidade do organismo de produzir eritrócitos novos, do que devido à remoção de eritrócitos infectados. Dessa forma, danos graves à saúde da ave infectada podem ocorrer antes mesmo de haver manifestação de parasitemia ${ }^{10,81}$.

\subsubsection{Ciclo de vida de Haemoproteus}

O ciclo de vida de Haemoproteus (Figura 3) é semelhante ao de Plasmodium. Os esporozoítos (1), injetados nas aves pelos vetores, inicialmente se desenvolvem em merontes exoeritrocíticos de primeira geração (2 e 3). São frequentemente encontrados nos pulmões e menos frequentes no fígado, baço, rins, coração, musculatura esquelética e outros órgãos. Os merontes variam em forma no endotélio pulmonar, podendo formar estruturas semelhantes a galhos ou vermiformes. Durante 
o desenvolvimento do meronte, eles podem se dividir em citômeros com vários núcleos cada um e infectar novas células (4). Os merontes podem variar significativamente de tamanho, mas geralmente não excedem os $100 \mu \mathrm{m}$. Em algumas espécies há o desenvolvimento de megalomerontes (5 e 6) nas células endoteliais dos capilares e nos miofibroblastos da musculatura esquelética e cardíaca. Esses podem chegar a $400 \mu \mathrm{m}$, se estendendo ao longo das fibras musculares e cercados por uma fina parede hialina. Os merozoítos formados nesta etapa são capazes de infectar as células sanguíneas (7) e se desenvolverem em gametócitos $(8)^{10}$.

Os megalomerontes de primeira geração infectam as células esplênicas (9), onde ocorrerá nova merogonia e formação de megalomerontes (10 e 11) capazes de infectar as células sanguíneas (12) e se desenvolverem em gametócitos (13) ${ }^{10}$.

Em geral, há pelo menos duas gerações teciduais antes do surgimento dos gametócitos na circulação. A primeira geração se desenvolve no endotélio capilar e miofibroblastos e em seguida produz merozoítos alongados. Essa fase se completa em cerca de cinco dias após a infecção. Os merozoítos alongados induzem a merogonia secundária e dão origem aos merontes nas células reticulares hepáticas, que são as prováveis responsáveis pela manutenção das parasitemias crônicas e recaídas. Os merontes de segunda geração, ou megalomerontes, ficam maduros em 17 dias após a infecção. Possuem numerosos merozoítos arredondados, que são capazes de infectar os eritrócitos, originando posteriormente os gametócitos. A fase pré-patente pode variar de 11 a 21 dias. Mais de um merozoíto pode infectar a mesma célula e conforme a infecção aumenta a chance de mais de um parasita infectar a mesma célula também aumenta. Porém não mais do que dois deles atingem a maturidade ${ }^{10}$.

A hemozoína é formada nos gametócitos e o seu número, formato e disposição possuem função taxonômica importante. Junto com o verdadeiro pigmento malárico existem, nos gametócitos de certas espécies, grânulos de valutim. Esses podem desenvolver tons de violeta e às vezes azuis. A natureza dos grânulos de valutim ainda não é totalmente compreendida. Eles são claramente diferenciáveis da hemozoína por sua refração menor da luz. A morfologia dos gametócitos e as suas 
características, bem como o impacto que produzem no formato dos eritrócitos infectados, são utilizadas para identificação morfológica ${ }^{10}$.

Gametócitos capazes de gametogênese aparecem com 2 a 6 dias após os merozoítos infectarem os eritrócitos. Após esse período, a capacidade de produzir gametas diminui. Estima-se que somente um a cada 1000 gametócitos tenha a capacidade de se tornar gameta. Gametócitos viáveis foram encontrados durante 80 dias de observação de $H$. fringillae, o que indica um grande número de ciclos exoeritrocíticos para manter esses parasitas circulantes viáveis e capazes de seguir com o ciclo, fazendo com que o parasita persista na ave, e sendo responsável pelas recaídas, que ocorrem principalmente durante a primavera, o período reprodutivo das $\operatorname{aves}^{10}$.

Como para Plasmodium, logo após a ingestão dos gametócitos durante o repasto sanguíneo do vetor, se inicia o processo de gametogênese (14 e 15). Os gametócitos assumem formato redondo e escapam do interior dos eritrócitos no intestino do vetor. O macrogametócito produz macrogametas arredondados (14) e o microgametócito sofre exflagelação originando oito microgametas móveis (15). A fertilização ocorre em ambiente extracelular e o zigoto (16) se transforma em um oocineto de formato arredondado móvel. O oocineto penetra através da membrana peritrófica e através da membrana epitelial do intestino (17). O oocineto assume forma arredondada e se transforma em oocisto (18) que é circundado por uma espécie de cápsula. Durante o processo de desenvolvimento do oocisto (esporogonia) (19), numerosos esporozoítos (20) são formados. Após a maturação do oocisto, os esporozoítos se movem pela hemocele e penetram nas glândulas salivares do vetor (21). Os esporozoítos são as formas infectantes para as aves e são injetados no hospedeiro vertebrado durante o repasto sanguíneo, fechando o ciclo ${ }^{10}$.

As espécies de Haemoproteus já estudadas que se desenvolvem em Ceratopogonidae levam entre 7 e 10 dias para completar todo o ciclo no vetor, enquanto que em Hippoboscidae levam mais de 10 dias $^{10}$. 


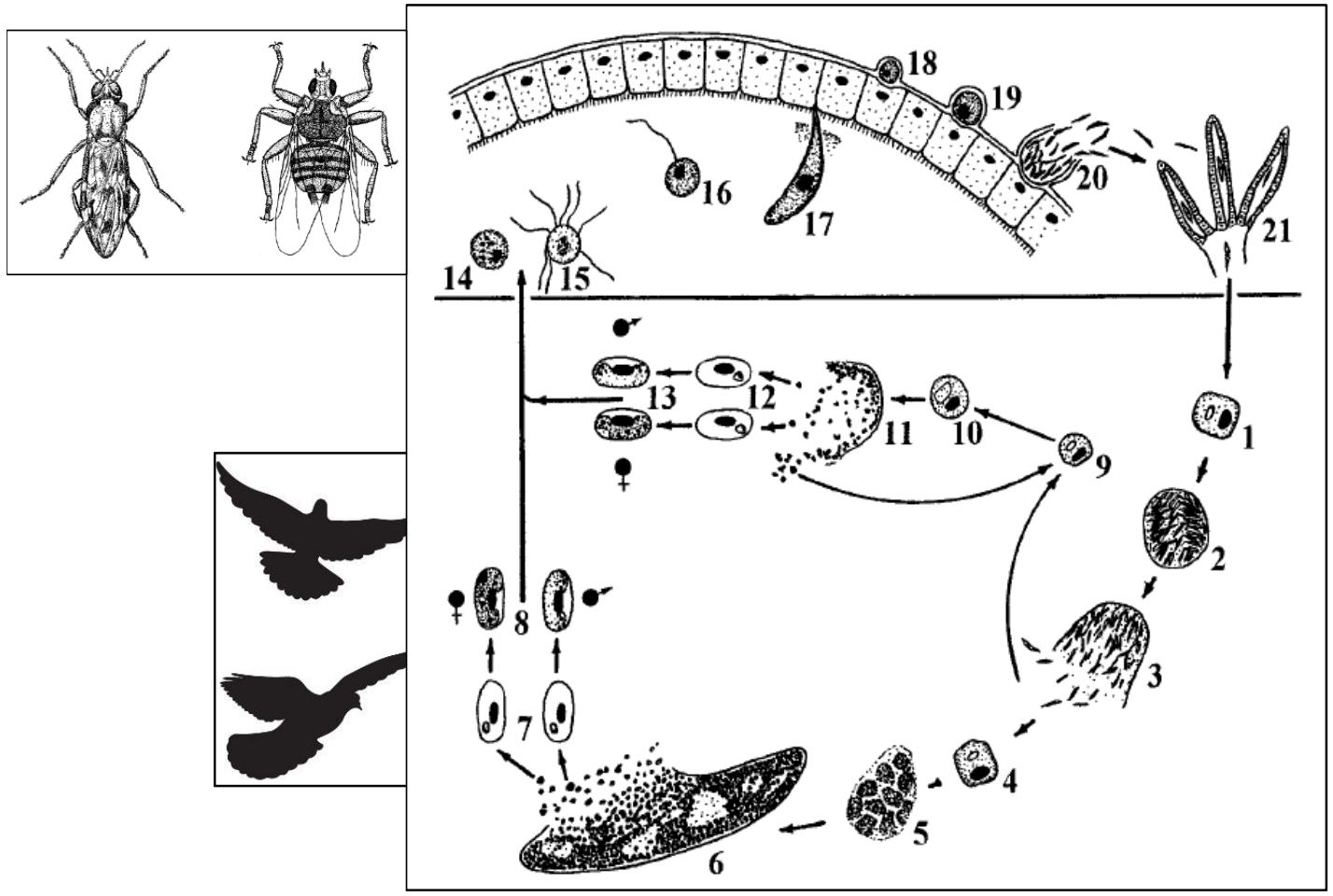

Figura 3 - Ciclo de vida de Haemoproteus spp. Ave: 1-13; Vetor: 14-21; 1 esporozoítos na célula endotelial; 2, 3 - merontes exoeritrocíticos de primeira geração com merozoítos alongados; 4 - merozoítos na célula endotelial; 5, 6 - megalomerontes "growing" e maduros nas células musculares esqueléticas, respectivamente; 12 - merozoítos em eritrócitos; 13 - gametócitos maduros; 14 - macrogametócitos; 15 exflagelação dos microgametócitos; 16 - fertilização do macrogametócito; 17 - oocineto penetrando na membrana peritrófica; 18 - oocisto jovem; 19, 20 - esporogonia; 21 - esporozoítos na glândula salivar do vetor (adaptado de Valkiūnas, 2005).

\subsection{Taxonomia e Diagnóstico}

A taxonomia de Haemosporida ainda é um desafio ${ }^{59}$. A descrição se dá através de análises morfométricas das formas parasitárias encontradas nos hospedeiros vertebrados, sendo utilizadas diversas características como: (i) a distribuição, a forma, o tamanho e a quantidade dos pigmentos de hemozoína; (ii) a influência do parasita nas células infectadas; (iii) e o tamanho do parasita em relação 
ao núcleo do eritrócito infectado ${ }^{10,60,66,81}$. Para tal identificação, os profissionais precisam ser treinados, mas, infelizmente, esse interesse vem se perdendo ao longo dos $\operatorname{anos}^{10,66}$.

Quando técnicas moleculares começaram a ser aplicadas para a pesquisa de Haemosporida em aves, o primeiro protocolo de reação em cadeia da polimerase (PCR) tinha como alvo sequências da subunidade menor do gene ribossomal (18S rRNA) $)^{82}$, mas funcionava apenas para um pequeno grupo de espécies de Plasmodium $^{53}$. Atualmente utilizam-se diferentes protocolos, com diferentes sequências alvo, mas os mais utilizados são aqueles que visam o gene mitocondrial citocromo b $(c y t b)^{83-86}$.

O MalAvi vem sendo amplamente utilizado por diferentes grupos de pesquisa em hemosporídeos ${ }^{29}, 39-41,48-49,53-56$, permitindo o desenvolvimento de marcadores moleculares e seu uso como código de barras de DNA (DNA barcoding). Esses contribuem para acelerar o diagnóstico das infecções naturais, principalmente as de baixas parasitemias, que apresentam dificuldade na identificação de espécies através da morfologia ${ }^{87}$.

As sequências gênicas encontradas nesses trabalhos estão depositadas nos bancos de dados de acesso público, GenBank e MalAvi, mas, em muitos casos, os parasitas foram identificados somente até o gênero ${ }^{66}$. Além disso, muitas sequências estão identificadas erroneamente, dificultando os estudos moleculares com este grupo $^{90}$. A correta identificação destes parasitas é essencial para o aumento do conhecimento das espécies, principalmente com relação aos animais silvestres ${ }^{66}$. A combinação da microscopia com o PCR é essencial para a correta identificação de Plasmodium, visto que em amostras com coinfecção, os protocolos de PCR tendem a favorecer a amplificação de sequências do parasita com maior parasitemia ${ }^{48}$ ou a amplificação da sequência com melhor correspondência com os primers ${ }^{89}$. A confirmação molecular de coinfecções representa um desafio para os pesquisadores da área. Recomenda-se a utilização de diferentes primers para diferentes marcadores na tentativa de amplificação de todas as sequências gênicas envolvidas na infecção ${ }^{86}$. Nesses casos a análise do esfregaço sanguíneo se mostra mais sensível do que o PCR, mas, sem o devido treinamento e conhecimento por parte do microscopista, podem ocorrer erros nas identificações ${ }^{88}$. 
Atualmente existem 361 linhagens diferentes de Haemosporida registradas na América do Sul ${ }^{91}$. Plasmodium possui 193 linhagens, com 15 delas identificadas até espécie, e 9 espécies descritas (P. elongatum, $P$. gallinaceum, $P$. homocircumflexum, P. homopolare, P. lutzi, P. nucleophilum, P. relictum, P. tejerai e P. unalis $)^{91}$. Haemoproteus tem 125 linhagens registradas na região, com 25 delas identificadas até espécie, e 9 espécies descritas (H. coatneyi, $H$. columbae, $H$. iwa, $H$. jenniae, $H$. macrovacuolatus, $H$. multipigmentatus, $H$. paramultipigmentatus, $H$. vireonis e $H$. witti) ${ }^{91}$, além de H. erythrogravidus, recentemente descrita ${ }^{34}$. Na América do Sul há também ocorrência de Leucocytozoon, com 43 linhagens e 6 delas identificadas até espécie (L. fringillinarum, L. pterotenuis e L. quynzae) ${ }^{91}$.

Com relação ao Brasil há um total de 341 ocorrências de hemosporídeos, sendo 57 em Haemoproteus e 284 em Plasmodium ${ }^{91}$. Não há registros de Leucocytozoon na região. Plasmodium tem registro de 110 linhagens e 5 espécies $(P$. nucleophilum, P. gallinaceum, $P$. relictum, $P$. elongatum e $P$. tejerai), enquanto que Haemoproteus registra 28 linhagens e ocorrência de 5 espécies (H. multipigmentatus, H. columbae, H. jenniae, H. macrovacuolatus e $H$. coatney) ${ }^{91}$.

A região Neotropical apresenta poucas espécies de Haemosporida descritas quando comparada a regiões temperadas, sendo Plasmodium o gênero mais frequente, com uma grande variedade de linhagens ${ }^{52}$. Na região neotropical há 18 espécies de Plasmodium já descritas, sendo 8 endêmicas ${ }^{10}$. Os subgêneros mais abundantes são Novyella e Giovannolaia. Para Haemoproteus esse número é um pouco maior, com 28 espécies descritas e 9 endêmicas, sendo Parahaemoproteus o subgênero mais abundante ${ }^{10}$.

Um dos maiores obstáculos para compreender a epidemiologia de Haemosporida é entender os mecanismos envolvidos nas interações entre o parasita e o vetor ${ }^{54,61-62}$. Devido à grande diversidade de espécies de parasitas e de vetores envolvidos, generalizações não são recomendadas. Alguns estudos apontam flutuações populacionais e taxa de picadas das fêmeas variando de acordo com o regime de chuvas ${ }^{92-93}$. Entretanto, é possível que criadouros estejam disponíveis durante todo o ano nas regiões tropicais ${ }^{94}$, principalmente em zoológicos ${ }^{95}$ aumentando as taxas de transmissão. Estudos com malária em áreas tropicais apontam que há correlação entre a abundância de mosquitos e as taxas de 
precipitação, com alterações sazonais na densidade do vetor, nas taxas de picadas e nas estruturas das comunidades, podendo variar entre diferentes áreas ${ }^{13}$.

Para um melhor conhecimento da epidemiologia de Haemosporida é necessário entender a importância de cada espécie de vetor na transmissão das diferentes linhagens de Haemosporida, o que é difícil de ser estudado em ambientes naturais, uma vez que os vetores e hospedeiros vertebrados podem circular livremente pelo seu habitat. Entretanto, quando esse estudo é feito em zoológicos, é possível determinar o raio de voo dos mosquitos, hábitos e preferências alimentares, uma vez que muitos animais possuem recinto fixo, facilitando essa análise ${ }^{96}$.

A compreensão dos fatores bióticos e abióticos envolvidos possibilita a criação de soluções para a melhor manutenção dos indivíduos em cativeiro e o desenvolvimento de projetos de conservação de espécies, diminuindo ou mesmo evitando infecções por parasitas e sua interferência na vida dos animais cativos. Além disso, pode auxiliar na compreensão dos aspectos evolutivos e das relações parasita-hospedeiro, principalmente em regiões pouco estudadas, como a região tropical. 


\section{OBJETIVOS}

\subsection{Objetivo Geral}

Este trabalho teve como objetivo verificar a ocorrência de Haemosporida em amostras oriundas de animais da Classe Aves e da Família Culicidae na Fundação Parque Zoológico de São Paulo (FPZSP).

\subsection{Objetivos Específicos}

a) Identificar morfologicamente as espécies de Plasmodium e Haemoproteus nos animais positivos;

b) Identificar geneticamente as espécies de Plasmodium e Haemoproteus nos animais positivos;

c) Estabelecer código de barras de DNA para as espécies de Plasmodium e Haemoproteus identificadas;

d) Comparar a eficiência das técnicas utilizadas na detecção de Plasmodium e Haemoproteus spp.;

e) Realizar levantamento da diversidade de Culicidae da FPZSP;

f) Identificar as fontes de repasto sanguíneo de Culicidae da FPZSP. 


\section{MATERIAL E MÉTODOS}

\subsection{Local de estudo}

A Fundação Parque Zoológico de São Paulo (FPZSP), está localizada no Parque Estadual das Fontes do Ipiranga (PEFI), Unidade de Conservação do Estado de São Paulo. A FPZSP foi fundada em 1958 e possui uma área de $824.529 \mathrm{~m}^{2}$ (Figura 4). No PEFI também estão localizados o Instituto de Botânica (IB) e o Instituto de Ciência e Tecnologia (CIENTEC), além do Zôo Safari (ZS), que faz parte da FPZSP.

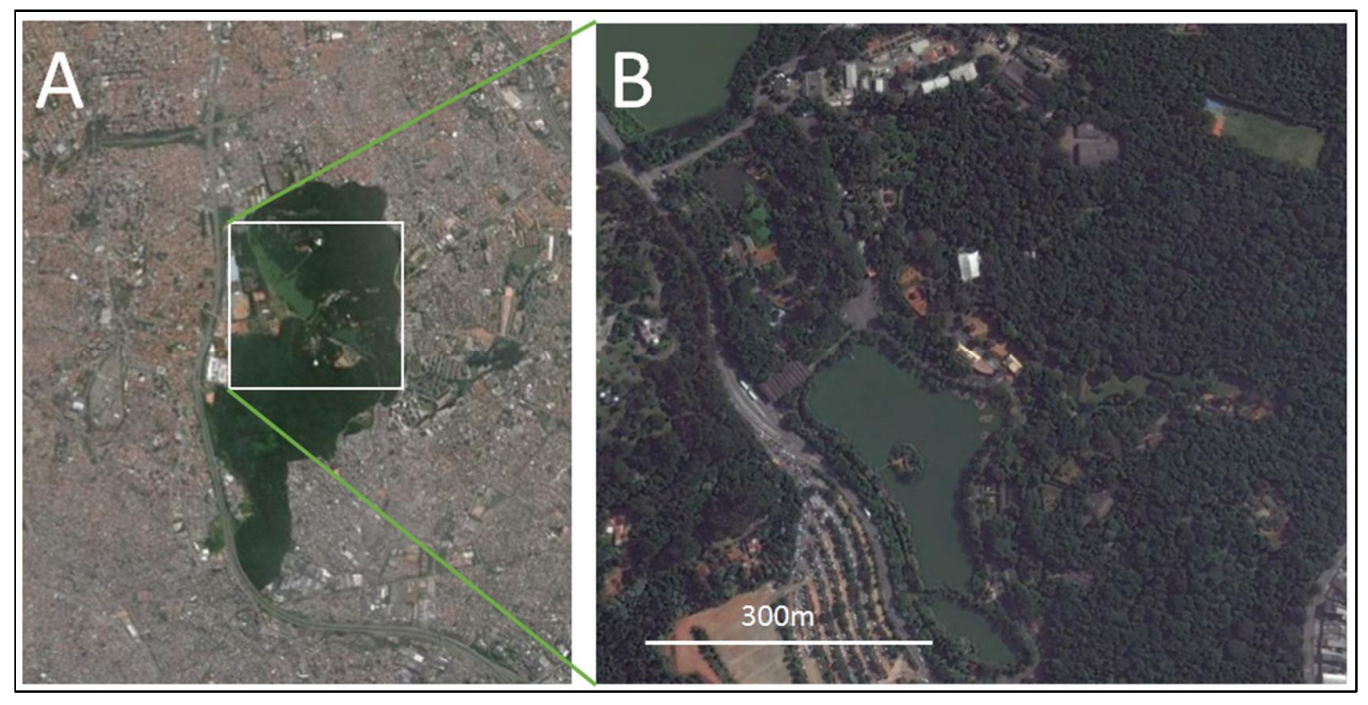

Figura 4 - Mapa de localização do PEFI (A) e, em aproximação, da FPZSP (B).

A FPZSP abriga em torno de 3.000 animais cativos, dentre aves, répteis, mamíferos, anfíbios e invertebrados. O parque está localizado em um pequeno fragmento de Mata Atlântica, que abriga uma grande diversidade de espécies nativas e migrantes, com destaque para Dendrocygna viduata (irerê), por ser uma das 
maiores populações a migrarem para a região. Por outro lado, há também animais que são considerados sinantrópicos como Columba livia (pombo-doméstico).

O clima da região é subtropical úmido, com duas estações do ano bem definidas, sendo uma seca, que ocorre nos meses de outono (abril a junho) e inverno (julho a setembro), e outra chuvosa, em geral durante a primavera (outubro a dezembro) e verão (janeiro a março). Os meses com menores índices de precipitação ocorrem entre maio e agosto, que também são normalmente os meses mais frios. A amplitude térmica diária é maior do que a anual ${ }^{97}$.

\subsection{Coleta das amostras: sangue e esfregaços sanguíneos}

O presente estudo utilizou amostras sanguíneas de aves silvestres cativas na FPZSP e de aves de vida livre do PEFI no período de dezembro de 2011 a julho de 2015. As amostras das aves foram colhidas durante procedimentos médicoveterinários por apresentarem algum tipo de sintomatologia clínica ou para a realização de exames preventivos. Os animais foram submetidos à contenção química ou física, de acordo com a avaliação médico-veterinária, não influenciando neste estudo. Somente amostras de animais vivos foram testadas.

O sangue foi colhido das veias metatarsal média, braquial ou jugular (Figura 5). Um volume entre 0,5 a $1 \mathrm{~mL}$ foi retirado do animal ${ }^{98}$, acondicionado em um tubo de coleta contendo heparina lítica ou EDTA e homogeneizado cuidadosamente a fim de se evitarem coágulos. Os esfregaços sanguíneos foram realizados imediatamente após a coleta, em lâminas de vidro limpas, sem adição de anticoagulantes, sendo secos à temperatura ambiente protegidos de poeira e insetos. Amostras de exemplares de vida livre de Dendrocygna viduata e de Penelope superciliaris foram cedidas de outros projetos (SISBIO 35166-2 e 41010-1) e utilizadas conforme descrito para os animais cativos. 

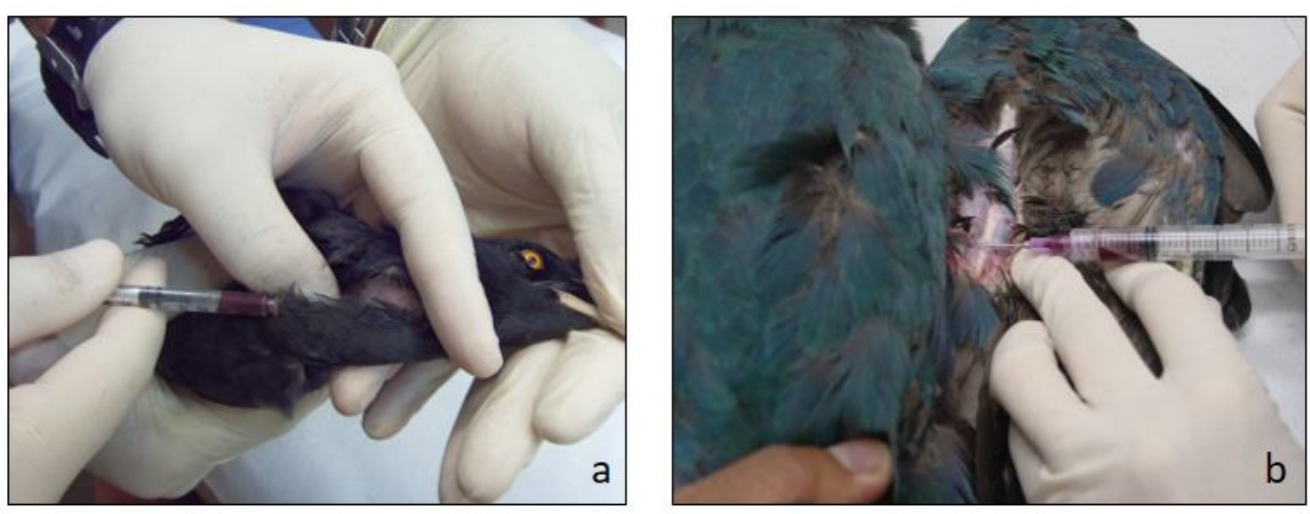

Figura 5 - Exemplos de coleta de sangue em Acridotheres cristatelus em veia jugular (a) e em veia braquial de exemplar de Anodorhynchus leari (b). Fotos: Carolina Chagas.

As amostras foram centrifugadas a $2.500 \mathrm{rpm}$ por 5 min para a separação dos eritrócitos e do plasma. Foram feitas alíquotas de $100 \mu \mathrm{L}$ de papa de eritrócitos que foram mantidas a $-20^{\circ} \mathrm{C}$ até a extração do DNA. As amostras foram identificadas com data de coleta, nome científico e numeração do espécime na FPZSP (cadastro).

O local de estudo encontra-se dentro de uma Unidade de Conservação que sofre grande pressão antrópica. Alguns animais de vida livre eventualmente necessitam de resgate por diversas razões. Esses animais recebem tratamento médico-veterinário e após avaliação clínica são soltos, incorporados ao plantel ou encaminhados a Centros de Resgate de Fauna Silvestre. Alguns desses animais tiveram suas amostras colhidas durante tratamento, e essas amostras foram utilizadas neste estudo e testadas da mesma forma que as demais.

\subsection{Análise microscópica dos esfregaços sanguíneos}

Os esfregaços sanguíneos foram fixados em metanol 100\% por imersão durante 1 minuto em até 24 horas após a coleta, secos à temperatura ambiente e corados com solução de Giemsa a $10 \%$, em até 30 dias após a fixação ${ }^{10}$. A análise dos esfregaços se deu através da observação de 100 campos no aumento de 400x 
seguido pela observação de, no mínimo, 100 campos em imersão $(1000 x)^{88}$. Quando a amostra foi positiva, determinou-se a parasitemia através da contagem de hemácias infectadas em 10.000 hemácias ${ }^{99}$.

\subsection{Extração de DNA genômico e amplificação do gene mitocondrial cytb de Haemosporida}

Após descongelamento, o sangue foi submetido ao processo de extração com o kit Wizard SV 96 Genomic DNA Purification System (PROMEGA®, Madison, Wisconsin, USA). As instruções do fabricante para a utilização do kit não incluíam o processamento de amostras sanguíneas de aves, uma vez que estas apresentam eritrócitos nucleados. Assim, algumas modificações foram realizadas no protocolo, de modo a impedir o entupimento da coluna e possibilitar a obtenção de DNA adequado para realização do PCR.

Primeiramente, $10 \mu 1$ do pellet de eritrócitos foram adicionados a $190 \mu 1$ de água ultrapura. Uma lise inicial foi realizada utilizando-se proteinase $\mathrm{K}$, numa concentração de $0,8 \mathrm{mg} / 200 \mu \mathrm{l}$ amostra, e incubação por 1 hora a $37^{\circ} \mathrm{C}$. Em seguida, $400 \mu 1$ de tampão de lise (Wizard® SV Lysis Buffer com Triton X-100 a 10\%) foram adicionados à amostra, incubando-se durante a noite à temperatura ambiente. $\mathrm{O}$ lisado foi transferido para a coluna e lavado de acordo com as instruções do fabricante. Ao término desse processo, o gDNA (DNA genômico) foi eluído em $100 \mu 1$ de água livre de nuclease e estocado a $-20^{\circ} \mathrm{C}$ até o processamento.

Todas as amostras foram quantificadas em NanoDrop ${ }^{\mathrm{TM}} 2000$ Spectrofotometer (Thermo Scientific $®)$ para verificar o rendimento da extração. Amostras com quantidade de DNA superior a 50ng/ $\mu 1$ foram diluídas, previamente à realização do protocolo de amplificação, para a concentração máxima de $25 \mathrm{ng} / \mu 1$.

O protocolo de amplificação utilizado tem por alvo um fragmento de $480 \mathrm{bp}$ do gene mitocondrial citocromo b (cytb) e se trata de um nested $\mathrm{PCR}^{84}$ (Figura 6). Na primeira reação foram utilizados os primers HaemNFI e HaemNR3 e uma concentração de 50ng do gDNA, 1,25 mM de dNTP, 1,5 mM $\mathrm{MgCl}_{2}, 0,6 \mathrm{mM}$ de 
cada primer e 0,5 U Taq DNA polimerase Platinum. A ciclagem da primeira reação de PCR consistiu em $94^{\circ} \mathrm{C}$ por $3 \mathrm{~min}, 30$ ciclos de $94^{\circ} \mathrm{C}$ por $30 \mathrm{seg}, 50^{\circ} \mathrm{C}$ por $30 \mathrm{seg}$ e $72^{\circ} \mathrm{C}$ por $45 \mathrm{seg}$, e $10 \mathrm{~min}$ a $72^{\circ} \mathrm{C}$ para a extensão final. Os primers da primeira reação são específicos para Plasmodium, Haemoproteus e Leucocytozoon. Em seguida, $1 \mu 1$ do produto da primeira reação de PCR foi utilizado para a reação nested, juntamente com os primers HaemF e HaemR2 específicos para amplificação de Plasmodium e Haemoproteus. As concentrações de reagentes e a ciclagem foram iguais às do primeiro PCR, com excessão da quantidade de ciclos que foram 35 .

Após as duas reações, os fragmentos foram resolvidos em gel de agarose a 1\%. As amostras positivas foram encaminhadas posteriormente para sequenciamento para diferenciação entre os gêneros e espécies de parasitas.

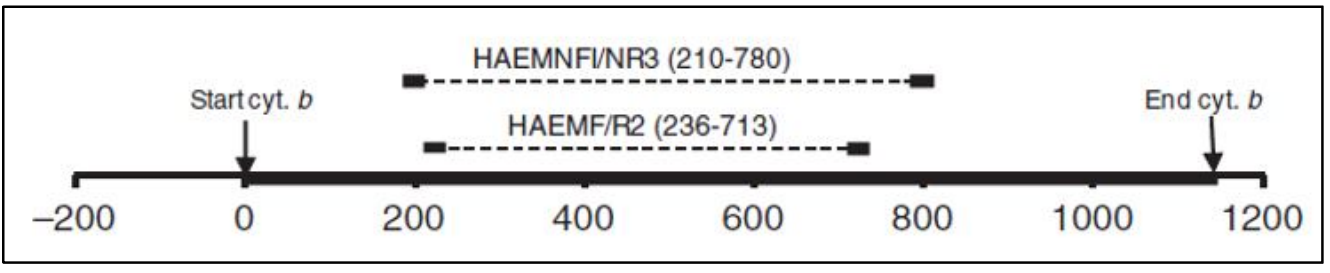

Figura 6 - Representação esquemática dos fragmentos amplificados para o gene $c y t b$ utilizando dois pares de oligonucleotídeos (caixas pretas). Números dentro dos parênteses representam o início e final do fragmento amplificado em relação ao início do gene (Adaptado de Bensch et al., 2009).

\subsection{Sequenciamento e análise das sequências}

Os produtos de PCR foram sequenciados em ABI Genetic Analyzer (ABI, USA) com o kit Big Dye Terminator v3.0 Cycle Sequencing Kit e os oligonucleotídeos HaemF e HaemR2. As sequências das duas fitas foram corrigidas e alinhadas em SeqMan (DNASTAR Lasergene versão 7.0.0) para criar sequência consenso.

Para identificar as linhagens encontradas, as sequências foram alinhadas com sequências do GenBank e MalAvi usando-se BLAST (Basic Local Alignment Search 
Tool), disponíveis em http://www.ncbi.nlm.nih.gov/blast/Blast.cgi e http://mbioserv2.mbioekol.lu.se/Malavi/blast.html. As sequências obtidas que diferiram em 1 nucleotídeo das sequências já depositas no MalAvi foram consideradas novas linhagens ${ }^{53,100}$ e depositadas nos bancos de dados (MalAvi e GenBank).

O relacionamento filogenético entre as linhagens identificadas foi inferido através do uso de sequências de cytb encontradas neste estudo e as depositadas no banco de dados MalAvi ${ }^{53}$. A reconstrução filogenética foi realizada separadamente para Plasmodium e Haemoproteus após alinhamento em ClustalX $1.8^{101}$. As árvores filogenéticas foram construídas pelo método de inferência Bayesiana implementado em MrBayes v3.2.0 ${ }^{102}$. Duas cadeias de Markov Monte Carlo foram corridas em 3 milhões de gerações cada uma com amostragem de 1 entre 300 árvores. As 25\% primeiras árvores foram descartadas como burn-in e as 15.002 árvores restantes foram utilizadas para calcular a árvore consenso. A filogenia foi visualizada através de FigTree versão 1.4.0 $0^{103}$.

Adicionalmente, para verificar as distâncias haplotípicas e a distribuição espacial dos haplótipos, bem como sua distribuição geofráfica e nas Ordens de hospedeiros, uma rede de haplótipos foi construída pelo método de median-joining utilizando-se o software Network (versão 4.6; www.fluxus-engineering.com) ${ }^{104}$. Foram selecionadas para essa análise, sequências do MalAvi com similaridade $\geq 96 \%$ com as linhagens deste estudo, totalizando 865 sequências de cytb de 41 linhagens de Plasmodium (Haemamoeba), com 467 bp cada sequência.

\subsection{Sazonalidade}

Para determinar se houve alguma sazonalidade no aparecimento das infecções, cada novo caso foi analisado de acordo com a data de detecção e classificado conforme a estação do ano (primavera, verão, outono e inverno). A análise de sazonalidade foi realizada considerando-se uma amostra por indivíduo (a primeira coleta). Os dados de todos os anos foram combinados. 


\subsection{Determinação do local provável de infecção e captura de mosquitos da Família Culicidae}

A manifestação de sinais clínicos após a infecção varia entre as espécies de Haemosporida. Além disso, alguns animais poderiam estar na fase crônica da doença. Portanto, para a determinação do local provável de infecção (LPI), foram levantadas informações da troca de recintos através das anotações nas fichas de controle de manejo animal da Divisão de Veterinária e do Setor de Aves da FPZSP. Foi considerado LPI o recinto em que o animal esteve nos 30 dias que antecederam a detecção da infecção.

A partir da identificação de LPIs, foram escolhidos 8 pontos para a colocação de armadilhas Mini CDC UV e 4 pontos para a realização da aspiração (Tabela 1, Figuras 7 e 8). A aspiração foi realizada com Aspirador de Nasci ${ }^{105}$ objetivando a coleta de fêmeas de mosquitos em repouso, concluindo as etapas da digestão sanguínea em seus abrigos pós-prandiais ${ }^{106}$. O aspirador foi acionado por 15 minutos em diferentes habitats que representam esses abrigos, totalizando duas horas, durante o período da manhã. A escolha dos pontos para aspiração foi realizada a partir das características da vegetação, visando àquelas que proporcionam abrigo para os mosquitos.

Tabela 1 - Coordenadas geográficas dos locais de instalação das armadilhas Mini CDC UV e de realização de aspiração (Aspirador de Nasci).

\begin{tabular}{|c|c|c|c|}
\hline & Tipo de armadilha & \multicolumn{2}{|c|}{ Coordenada geográfica } \\
\hline Ponte (PO) & $\mathrm{CDC}$ & $23^{\circ} 39^{\prime} 08^{\prime \prime} \mathrm{S}$ & $46^{\circ} 37^{\prime} 04^{\prime \prime} \mathrm{W}$ \\
\hline Recinto 69 (R69) & $\mathrm{CDC}$ & $23^{\circ} 39^{\prime} 11^{\prime \prime} \mathrm{S}$ & $46^{\circ} 37^{\prime} 07^{\prime \prime} \mathrm{W}$ \\
\hline Lago 70 (L70) & CDC / Nasci & $23^{\circ} 39^{\prime} 07^{\prime \prime} \mathrm{S}$ & $46^{\circ} 37^{\prime} 06^{\prime \prime} \mathrm{W}$ \\
\hline $\operatorname{Extra}(\mathbf{E X})$ & $\mathrm{CDC}$ & $23^{\circ} 38^{\prime} 49^{\prime \prime} \mathrm{S}$ & $46^{\circ} 37^{\prime} 14^{\prime \prime} \mathrm{W}$ \\
\hline Bosque das Aves (BA) & CDC / Nasci & $23^{\circ} 38^{\prime} 53^{\prime \prime} \mathrm{S}$ & $46^{\circ} 37^{\prime} 14^{\prime \prime} \mathrm{W}$ \\
\hline R. Flamingo (FM) & CDC / Nasci & $23^{\circ} 38^{\prime} 56^{\prime \prime} \mathrm{S}$ & $43^{\circ} 37^{\prime} 15^{\prime \prime} \mathrm{W}$ \\
\hline Recinto 113 (R113) & CDC / Nasci & $23^{\circ} 38^{\prime} 57^{\prime \prime} \mathrm{S}$ & $46^{\circ} 37^{\prime} 03^{\prime \prime} \mathrm{W}$ \\
\hline Recinto 61 (R61) & $\mathrm{CDC}$ & $23^{\circ} 39^{\prime} 01^{\prime \prime} \mathrm{S}$ & $46^{\circ} 37^{\prime} 03^{\prime \prime} \mathrm{W}$ \\
\hline
\end{tabular}


A captura dos mosquitos foi realizada com armadilhas luminosas CDC Miniatura $^{107}$ com luz ultravioleta. Pacotes de aproximadamente $1 / 2$ kilo de gelo seco, feitos com papel jornal e saco de lixo preto, foram acondicionados na lateral de cada armadilha, como fonte de dióxido de carbono $\left(\mathrm{CO}_{2}\right)$, com o objetivo de aumentar a atração das fêmeas dos mosquitos para as armadilhas (Figura 8). As armadilhas foram instaladas em troncos de árvores e acionadas durante o período crepuscular vespertino, sendo retiradas pela manhã do dia seguinte, ficando em funcionamento por cerca de 12 horas.

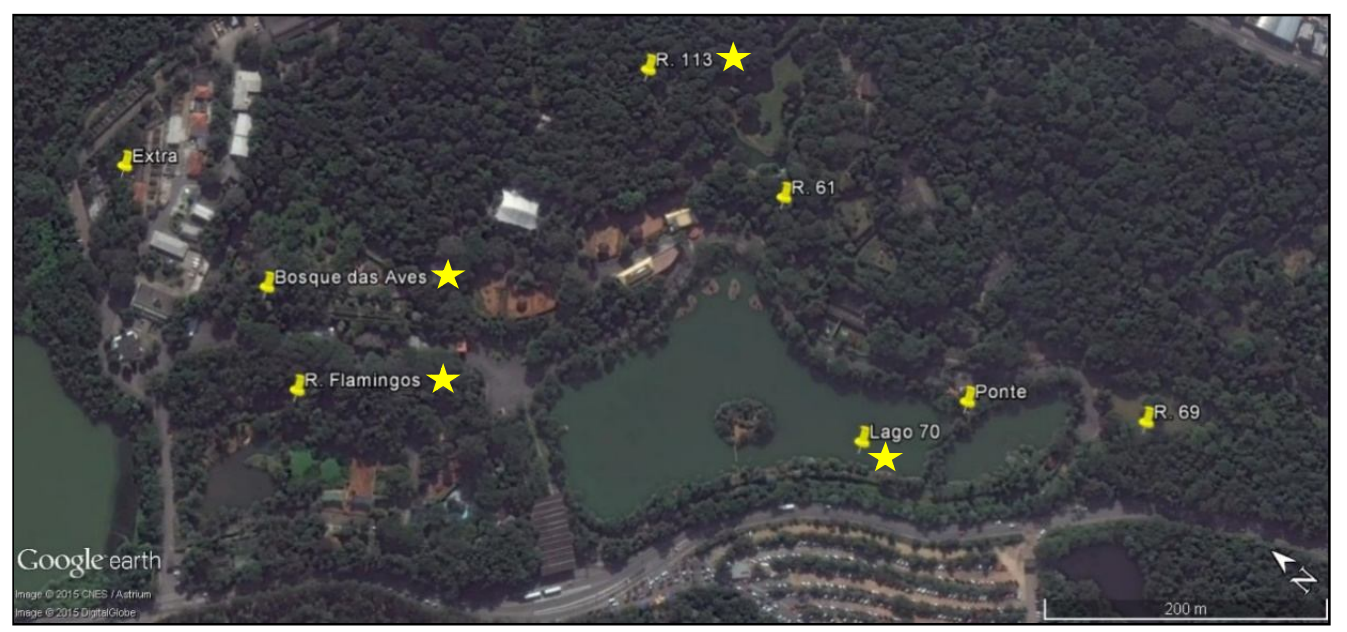

Figura 7 - Pontos de coleta de Culicidae. Em todos os pontos indicados foram instaladas armadilhas Mini CDC UV. Nos pontos indicados com estrela foram realizadas coletas através de Aspirador de Nasci.
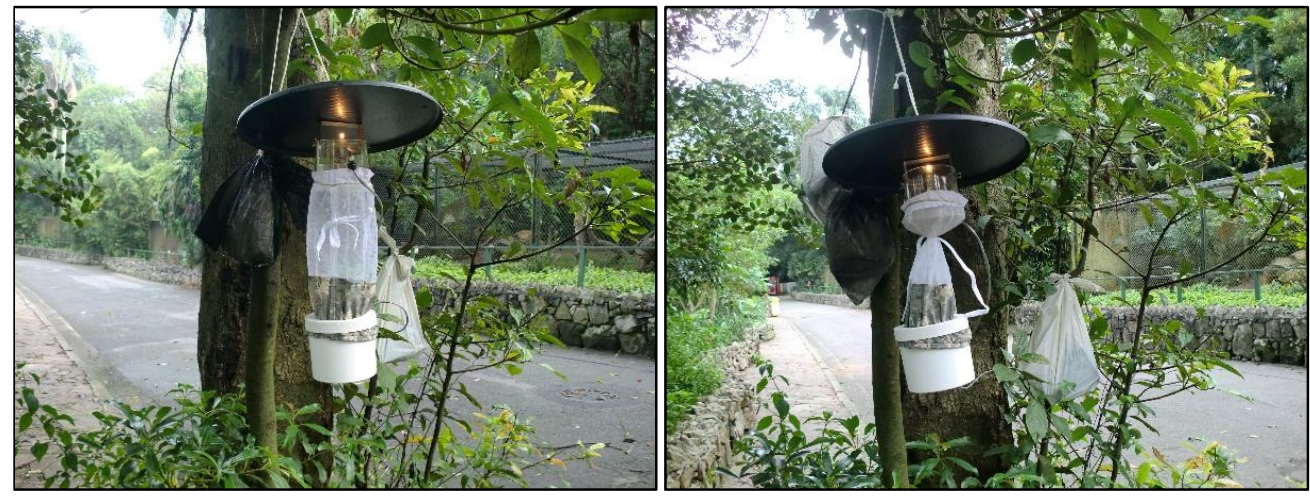

Figura 8 - Armadilha CDC Mini UV (Fotos: Carolina Chagas). 
Imediatamente após as coletas, os espécimes de insetos foram mortos, com vapor de clorofórmio, e triados. Os espécimes de Culicidae foram acondicionados em recipientes de plástico e transportados em gelo reciclável para o Laboratório de Entomologia Médica da Superintendência de Controle de Endemias (SUCEN), onde foram mantidos em freezer e identificados, até a categoria de espécie, em mesa fria por meio de microscópio estereoscópico.

Para todas as identificações foram utilizadas chaves e descrições taxonômicas conhecidas na literatura da família Culicidae ${ }^{108}$. Para análise de hábito alimentar foram consideradas desde as fêmeas com repleção abdominal até as que apresentavam apenas um traço de sangue somente visualizado pelo lado ventral do abdome, ou seja, dos esternitos abdominais.

Após identificação, separou-se cada exemplar em 2 porções: (i) cabeça e tórax, e (ii) abdômen. Cada porção foi acondicionada em tubos de 1,5 ml, marcados de acordo com espécie e local de captura e estocados a $-20 \circ \mathrm{C}$.

\subsection{Extração de gDNA de mosquitos ingurgitados e identificação da fonte de repasto sanguíneo}

O gDNA dos mosquitos ingurgitados foi extraído da porção do abdômen com kit Wizard SV 96 Genomic DNA Purification System (PROMEGA®, Madison, Wisconsin, USA), seguindo-se as instruções do fabricante para extração de DNA de tecidos.

Para a amplificação do DNA da fonte de repasto sanguíneo, foram utilizados diferentes pares de primers, capazes de amplificar fragmentos de diferentes tamanhos no gene mitocondrial $c y t b$, desde $\sim 300$ bp até $\sim 1 \mathrm{~kb}$ em vários grupos de vertebrados (aves, répteis, mamíferos e anfíbios) ${ }^{109-114}$.

Os fragmentos amplificados foram purificados e sequenciados diretamente com os primers flanqueadores correspondentes. As sequências foram identificadas por comparação com o banco de dados GenBank (www.ncbi.nlm.nih.gov/blast/Blast.cgi). Identificação positiva e atribuição da 
espécie fonte do repasto sanguíneo foram realizadas quando uma sequência exata ou com $>98 \%$ de identidade foi obtida ${ }^{115-116}$.

\subsection{Análise estatística}

A análise estatística foi realizada utilizando-se o programa SPSS (Statistical Package for the Social Sciences) para Windows, versão 15.0 (SPSS Inc., Chicago, IL, USA) e o Microsoft Excel. Para acessar os efeitos de cinco variáveis independentes (Família, estação, gênero, idade e tempo de cativeiro) na positividade de hemosporídeos, foram utilizados os testes de qui-quadrado, exato de Fisher ou testes de verossimilhança. Foi considerado como significativo $p<0,05$.

\subsection{Aspectos éticos}

O projeto recebeu autorização do SISBIO (Sistema de Autorização e Informação em Biodiversidade) do IBAMA (Instituto Brasileiro do Meio Ambiente e dos Recursos Naturais Renováveis, Ministério do Meio Ambiente), sob nº 34605 (ANEXO A), e do Comitê de Pesquisa do Instituto de Medicina Tropical sob $\mathrm{n}^{\circ}$

CEP/193 (ANEXO B) e CEP/294 (ANEXO C). Foram cedidas amostras referentes aos projetos registrados no SISBIO sob n 41010-1 e 35166-2. 


\section{RESULTADOS}

Além dos animais cativos, também foi possível amostrar indivíduos de vida livre que vivem na área de estudo. Os resultados apresentados a seguir se referem somente aos animais cativos, os resultados referentes aos animais de vida livre estão apresentados no Apêndice C.

\subsection{Perfil dos animais amostrados}

A classificação taxonômica das espécies amostradas neste estudo segue The Clements Checklist ${ }^{117}$. Atualmente, com mudanças taxonômicas contínuas, o Laboratório de Ornitologia da Universidade de Cornell, USA, tem a tarefa de manter

a lista em constante atualização e, portanto, The Clements Checklist apresenta o compêndio mais avançado e mais amplamente aceito, com mais de 9.930 espécies de aves reconhecidas pela comunidade científica. The Clements Checklist descreve atualmente 38 Ordens para a Classe Aves. Neste estudo foi possível amostrar animais de 17 delas $(44,7 \%)$.

Entre dezembro/2011 e julho/2015 foram colhidas 1254 amostras, de 677 indivíduos, de 122 espécies, 29 Famílias e 17 Ordens. Em dezembro/2015 a FPZSP possuía um plantel com 1609 espécimes de Aves de 118 espécies, dentre as quais foi possível amostrar 96 espécies $(81,4 \%)$, visto que 26 das 122 espécies amostradas não fazem mais parte do plantel $^{118}$.

As Ordens Anseriformes e Psittaciformes foram consideradas abundantemente amostradas, correspondendo, juntas, a $62,5 \%$ dos indivíduos analisados. Houve também um grupo de Ordens moderadamente amostradas (entre 4 e $8 \%$ ), que somam juntas 26,6\% dos indivíduos analisados (Galliformes, Phoenicopteriformes, Accipitriformes e Piciformes). Um terceiro grupo, com os animais de Ordens consideradas raramente amostradas $(0,3$ a $1,9 \%)$ e que somam 10,9\%, inclui 11 diferentes Ordens (Gráfico 1). 


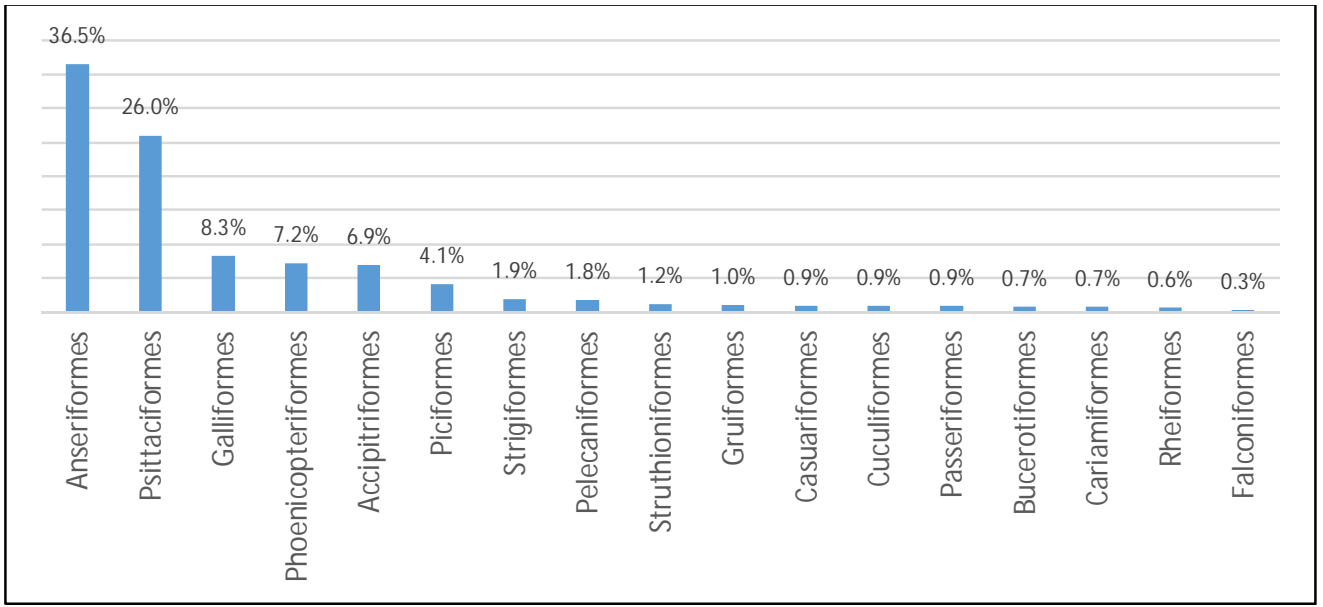

Gráfico 1 - Distribuição dos Indivíduos amostrados segundo Ordem.

Com relação às Famílias, Anatidae (36,3\%) e Psittacidae (25,7\%) apresentaram maior número de indivíduos amostrados e correspondem a $62 \%$ das amostras analisadas. As Famílias moderadamente amostradas, somando 30,1\%, foram Phoenicopteridae (7,2\%), Accipitridae (5,9\%), Phasianidae (5,2), Ramphastidae (4,1\%), Cracidae (2,7), Strigidae (1,5), Threskiornitidae (1,3\%) Sthruthionidae $(1,2 \%)$ e Cathartidae $(1 \%)$. Dezoito Famílias foram raramente amostras, com prevalência menor do que $1 \%$ cada (Casuaridae, Gruidae, Musophagidae, Bucorvidae, Cariamidae, Rheidae, Odontophoridae, Pelecanidae, Tytonidae, Cacatuidae, Cotingidae, Falconidae, Sturnidae, Anhimidae, Bucerotidae, Icteridae, Rallidae, Thraupidae) (Gráfico 2).

As espécies com maior número de amostras analisadas foram Cygnus atratus (18,2\%), Phoenicopterus chilensis (5\%), Cygnus melanocoryphus (4,6\%) e Pavo cristatus (4,6\%). Uma grande fração das espécies amostradas (82,8\%), 101 no total, possui menos de $1 \%$ dos indivíduos amostrados cada. A Família com maior diversidade de espécies estudadas foi Psittacidae, com 38 espécies distintas (Apêndice A). 


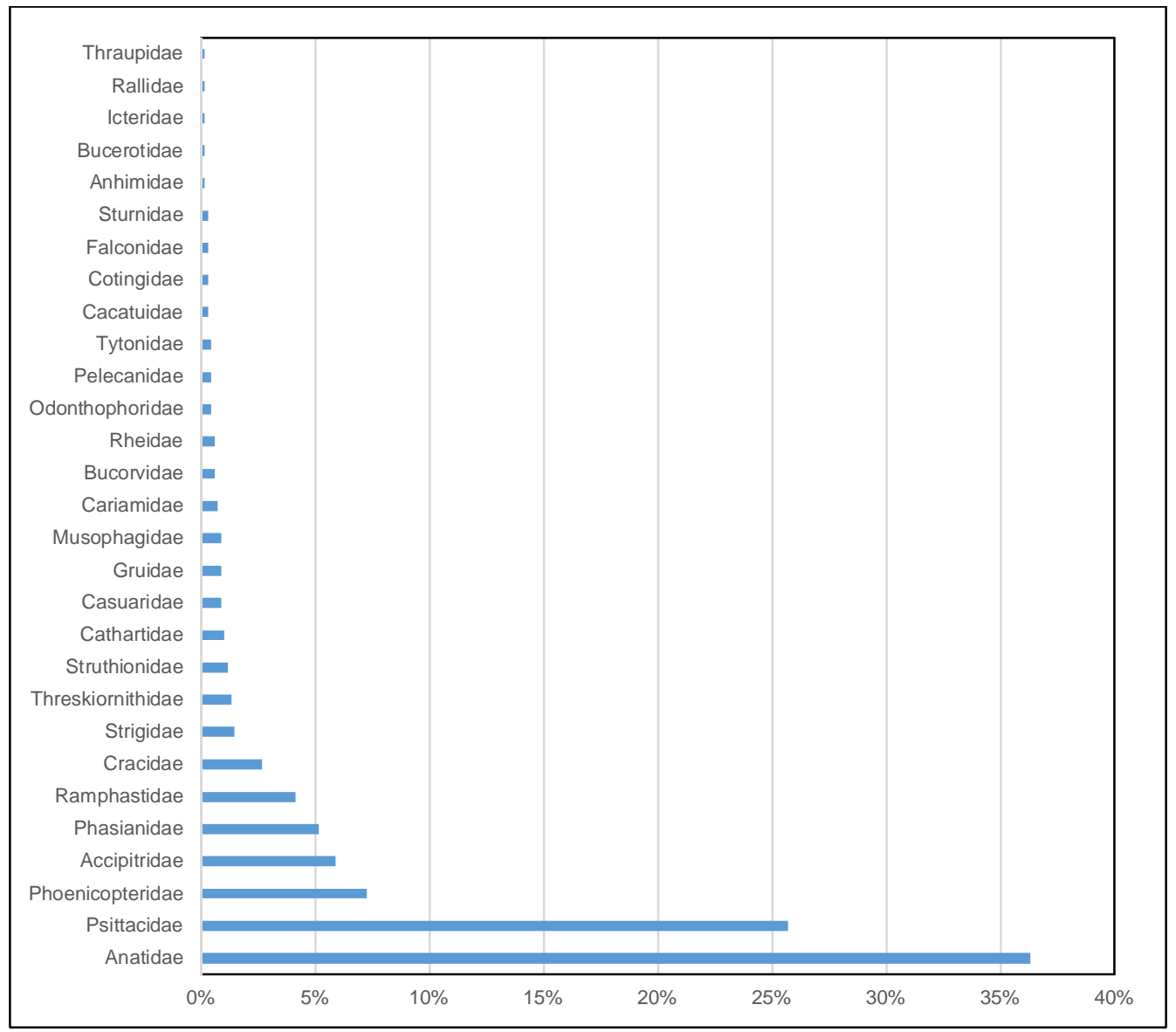

Gráfico 2 - Distribuição dos indivíduos amostrados segundo Família.

Em relação ao sexo dos animais analisados, 41,5\% eram machos, 40,5\% fêmeas e em $18 \%$ dos indivíduos não foi possível determinar o sexo, uma vez que nem todas as espécies de Aves possuem dimorfismo sexual e a sexagem somente é possível através de testes genéticos. Com relação à idade dos animais, a grande maioria dos indivíduos $(87,4 \%)$ estava em idade adulta.

\subsection{Perfil dos animais positivos}

Após a realização das análises, foi verificado que 85 (12,6\%) indivíduos eram positivos para Plasmodium/Haemoproteus representando 11 Ordens (64,7\%), 14 
Famílias (48,3\%) e 33 espécies (27\%). A Ordem com maior positividade foi Anseriformes (64,7\%), seguida por Galliformes (11,8\%), Psittaciformes (5,9\%) Accipitriformes, Phoenicopteriformes e Piciformes (3,5\% cada), Passeriformes $(2,4 \%)$ e Cuculiformes, Gruiformes, Pelecaniformes e Struthioniformes (com 1,2\% cada) (Gráfico 3). Anatidae foi a Família que apresentou maior prevalência (64,7\%), seguida por Cracidae, Phasianidae e Psittacidae (5,9\% cada), Phoenicopteridae e Ramphastidae (3,5\% cada), Cathartidae $(2,4 \%)$ e Acciptridae, Icteridae, Musophagidae, Rallidae, Sthruthionidae, Thraupidae e Threskiornitidae (1,2\% cada) (Gráfico 4). Pertencer à Família Anatidae foi significantemente associado à positividade $(p<0.05)$.

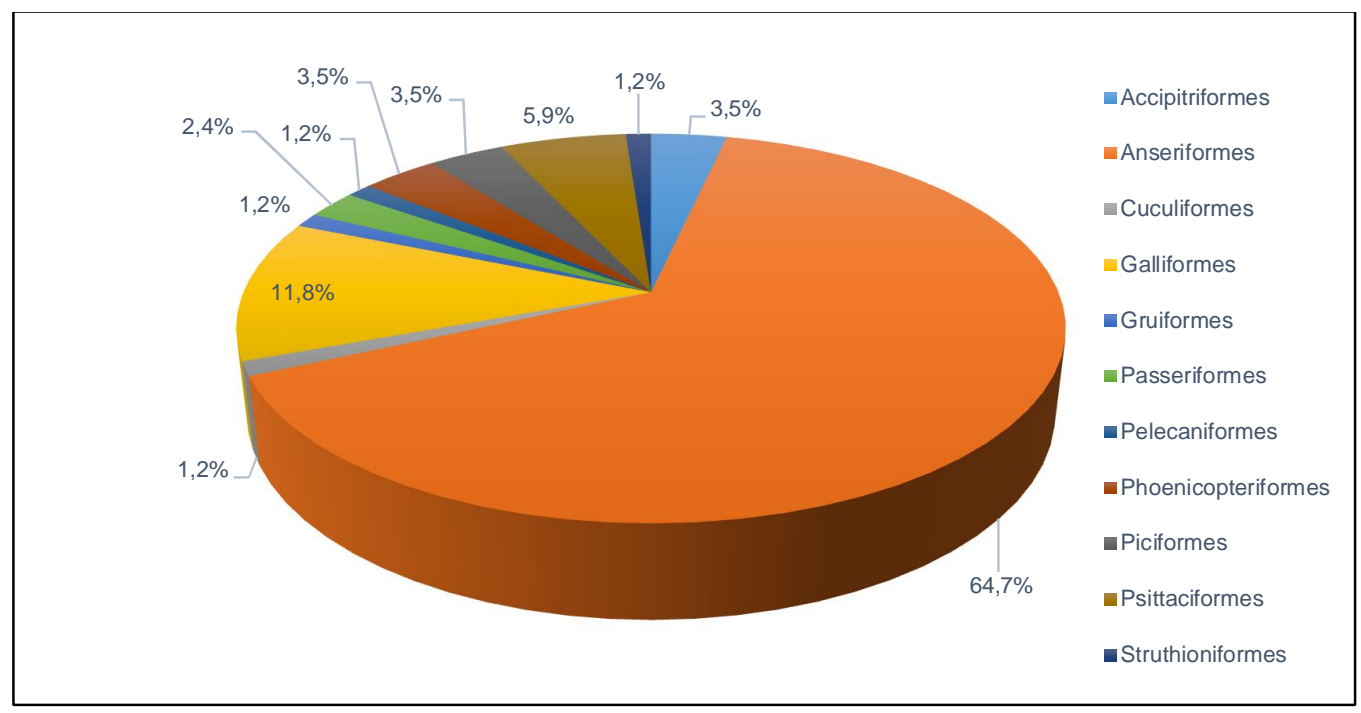

Gráfico 3 - Distribuição dos indivíduos positivos para Plasmodium/Haemoproteus segundo Ordem. 


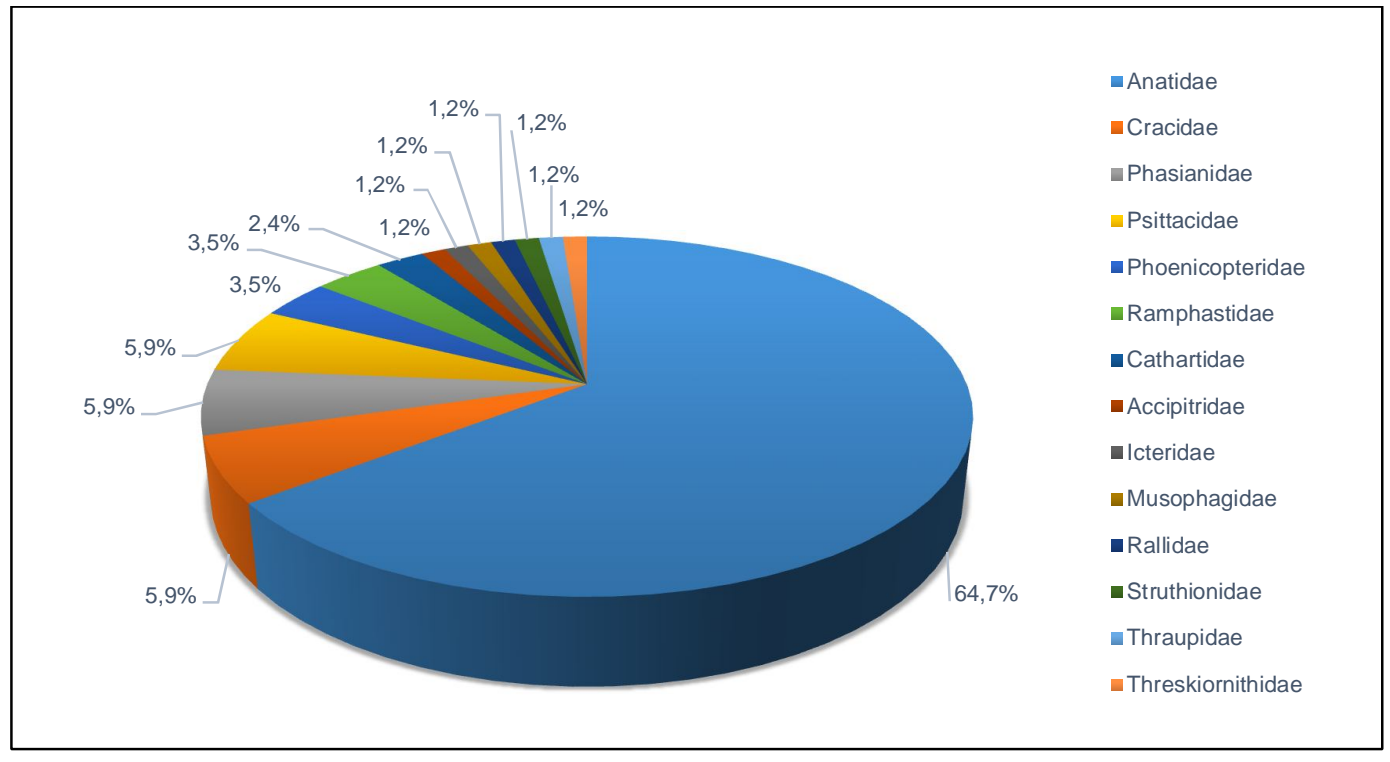

Gráfico 4 - Distribuição dos indivíduos positivos para Plasmodium/Haemoproteus segundo Família.

Pouco mais da metade das Famílias estudadas (51,7\%) não apresentaram nenhum indivíduo positivo para Plasmodium ou Haemoproteus, são elas: Anhimidae (Anseriformes), Bucerotidae e Bucorvidae (Bucerotiformes), Falconidae (Falconiformes), Odonthophoridae (Galliformes), Cariamidae e Gruidae (Gruiformes), Cotingidae e Sturnidae (Passeriformes), Pelecanidae (Pelecaniformes), Cacatuidae (Psittaciformes), Rheidae (Rheiformes), Strigidae e Tytonidae (Strigiformes), Casuaridae (Casuariformes).

No total, 33 espécies foram positivas para Plasmodium ou Haemoproteus, sendo que destas, 21 ocorrem no Brasil: Amazona aestiva, Amazonetta brasiliensis, Anodorhynchus hyacinthinus, Aramides cajanus, Buteogallus urubitinga, Coscoroba coscoroba, Cyanopsitta spixii, Cygnus melanocoryphus, Dendrocygna viduata, Eudocimus ruber, Guarouba guarouba, Mitu tomentosum, Netta erythrophthalma, Nothocrax urumutum, Penelope obscura, Pipile jacutinga, Psarocolius decumanus, Ramphastos toco, Ramphastos vitellinus, Saltator atricolis, Sarcoramphus papa (Tabela 2). Algumas dessas espécies possuem algum grau de ameaça, de acordo com a lista vermelha de espécies ameaçadas da $\operatorname{IUCN}^{119}$ (Tabela 2). 
Tabela 2 - Aves com resultados positivos no PCR para Plasmodium/Haemoproteus e suas respectivas linhagens.

\begin{tabular}{|c|c|c|c|c|c|}
\hline $\begin{array}{l}\text { ORDEM } \\
\text { Família }\end{array}$ & $\begin{array}{l}\text { Espécie hospedeiro } \\
\text { (Nome comum) }\end{array}$ & $\begin{array}{c}\text { AVES } \\
\text { (POSITIVAS) }\end{array}$ & $\begin{array}{l}\text { AMOSTRAS } \\
\text { (POSITIVAS) }\end{array}$ & Parasitas E LINHAGENS & GENBANK \\
\hline \multicolumn{6}{|c|}{ ACCIPITRIFORMES } \\
\hline Accipitridae & $\begin{array}{l}\text { Buteogallus urubitinga } \\
\text { (gavião-preto) }\end{array}$ & $1(1)$ & $6(1)$ & Plasmodium sp. PESA01 & EU684543 \\
\hline Cathartidae & $\begin{array}{l}\text { Sarcoramphus papa } \\
\text { (urubu-rei) }\end{array}$ & $6(2)$ & $10(3)$ & Plasmodium sp. NYCNYC01 & KU057967 \\
\hline \multicolumn{6}{|c|}{ ANSERIFORMES } \\
\hline \multirow[t]{8}{*}{ Anatidae } & $\begin{array}{l}\text { Alopochen aegyptiaca } \\
\text { (ganso-do-Egito) }\end{array}$ & $10(5)$ & $18(7)$ & $\begin{array}{l}\text { Plasmodium nucleophilum DENPET03 } \\
\text { Plasmodium sp. DENVID01 } \\
\text { Plasmodium sp. NYCNYC01 }\end{array}$ & $\begin{array}{l}\text { AY640137 } \\
\text { KU057966 } \\
\text { KU057967 }\end{array}$ \\
\hline & $\begin{array}{l}\text { Amazonetta brasiliensis } \\
\text { (pé-vermelho) }\end{array}$ & $4(1)$ & $8(1)$ & Plasmodium sp. NYCNYC01 & KU057967 \\
\hline & $\begin{array}{l}\text { Anser cygnoides } \\
\text { (ganso-siberiano) } * *\end{array}$ & $1(1)$ & $4(4)$ & $\begin{array}{l}\text { Plasmodium sp. NYCNYC01 } \\
\text { Plasmodium sp. PADOM09 }\end{array}$ & $\begin{array}{l}\text { KU057967 } \\
\text { AF069611 }\end{array}$ \\
\hline & $\begin{array}{l}\text { Cereopsis novahollandiae } \\
\text { (ganso-australiano) }\end{array}$ & $12(1)$ & $19(1)$ & Plasmodium sp. CERNOV01 & KX171623 \\
\hline & $\begin{array}{l}\text { Coscoroba coscoroba } \\
\text { (capororoca) }\end{array}$ & $24(1)$ & $39(1)$ & Plasmodium elongatum GRW06 & DQ368381 \\
\hline & $\begin{array}{l}\text { Cygnus atratus } \\
\text { (cisne-preto) }\end{array}$ & $123(32)$ & $175(53)$ & $\begin{array}{l}\text { Plasmodium nucleophilum DENPET03 } \\
\text { Plasmodium sp. DENVID01 } \\
\text { Plasmodium elongatum GRW06 } \\
\text { Plasmodium sp. MYCAME02 } \\
\text { Plasmodium sp. NYCNYC01 } \\
\text { Plasmodium sp. PESA01 }\end{array}$ & $\begin{array}{c}\text { AY640137 } \\
\text { KU057966 } \\
\text { DQ368381 } \\
\text { JX546135 } \\
\text { KU057967 } \\
\text { EU684543 }\end{array}$ \\
\hline & $\begin{array}{l}\text { Cygnus melanocoryphus } \\
\text { (cisne-pescoço-preto) }\end{array}$ & $31(3)$ & $75(5)$ & $\begin{array}{l}\text { Plasmodium sp. NYCNYC01 } \\
\text { Plasmodium sp. PESA01 }\end{array}$ & $\begin{array}{l}\text { KU057967 } \\
\text { EU684543 }\end{array}$ \\
\hline & $\begin{array}{l}\text { Dendrocygna viduata } \\
\text { (irerê) }\end{array}$ & $4(1)$ & $5(1)$ & Plasmodium sp. NYCNYC01 & KU057967 \\
\hline
\end{tabular}




\begin{tabular}{|c|c|c|c|c|c|}
\hline Continuação & $\begin{array}{l}\text { Netta erythrophthalma } \\
\text { (paturi) }\end{array}$ & $2(1)$ & $2(1)$ & Plasmodium nucleophilum DENPET03 & AY640137 \\
\hline & $\begin{array}{l}\text { Plectropterus gambensis } \\
\text { (ganso-da-Gâmbia) }\end{array}$ & $7(1)$ & $16(1)$ & Plasmodium sp. NYCNYC01 & KU057967 \\
\hline & $\begin{array}{l}\text { Tadorna ferruginea } \\
\text { (tadorna-ferrugem) }\end{array}$ & $10(7)$ & $28(10)$ & $\begin{array}{l}\text { Plasmodium sp. NYCNYC01 } \\
\text { Plasmodium sp. DENVID01 }\end{array}$ & $\begin{array}{l}\text { KU057967 } \\
\text { KU057966 }\end{array}$ \\
\hline & $\begin{array}{l}\text { Tadorna variegata } \\
\text { (tadorna-paraíso) }\end{array}$ & $1(1)$ & $5(4)$ & Plasmodium sp. NYCNYC01 & KU057967 \\
\hline \multicolumn{6}{|c|}{ CUCULIFORMES } \\
\hline Musophagidae & $\begin{array}{l}\text { Musophaga violacea } \\
\text { (uraco-violeta) }\end{array}$ & $2(1)$ & $3(1)$ & Plasmodium sp. SPMAG06 & HM031936 \\
\hline \multicolumn{6}{|c|}{ GALLIFORMES } \\
\hline \multirow[t]{4}{*}{ Cracidae } & $\begin{array}{l}\text { Mitu tomentosum } \\
\text { (mutum-do-nordeste) } *\end{array}$ & $5(1)$ & $10(1)$ & Plasmodium sp. MITOM01 & KX171625 \\
\hline & $\begin{array}{l}\text { Nothocrax urumutum } \\
\text { (urumutum) }\end{array}$ & $5(1)$ & $9(1)$ & Plasmodium sp. NOTURU01 & KX171626 \\
\hline & $\begin{array}{l}\text { Penelope obscura } \\
\text { (jacu-guaçu) }\end{array}$ & $2(1)$ & $2(1)$ & Haemoproteus ortalidum PENOBS01 & KX171627 \\
\hline & $\begin{array}{l}\text { Pipile jacutinga } \\
\text { (jacutinga) } * * *\end{array}$ & $3(2)$ & $9(3)$ & $\begin{array}{l}\text { Plasmodium sp. NYCNYC01 } \\
\text { Plasmodium nucleophilum DENPET03 }\end{array}$ & $\begin{array}{l}\text { KU057967 } \\
\text { AY640137 }\end{array}$ \\
\hline \multirow[t]{2}{*}{ Phasianidae } & $\begin{array}{l}\text { Pavo cristatus } \\
\text { (pavão-azul) }\end{array}$ & $31(4)$ & $53(5)$ & $\begin{array}{l}\text { Plasmodium elongatum GRW06 } \\
\text { Plasmodium sp. DENVID01 }\end{array}$ & $\begin{array}{l}\text { DQ368381 } \\
\text { KU057966 }\end{array}$ \\
\hline & $\begin{array}{l}\text { Pavo muticus } \\
\text { (pavão-verde) } * * *\end{array}$ & $4(1)$ & $7(3)$ & Plasmodium sp. DENVID01 & KU057966 \\
\hline \multicolumn{6}{|l|}{ GRUIFORMES } \\
\hline Rallidae & $\begin{array}{l}\text { Aramides cajaneus } \\
\text { (saracura-três-potes) }\end{array}$ & $1(1)$ & $2(1)$ & Plasmodium sp. ARACAJ01 & KX171622 \\
\hline \multicolumn{6}{|c|}{ PASSERIFORMES } \\
\hline Icteridae & $\begin{array}{l}\text { Psarocolius decumanus } \\
\text { (japu) }\end{array}$ & $1(1)$ & $1(1)$ & Plasmodium nucleophilum DENPET03 & AY640137 \\
\hline
\end{tabular}




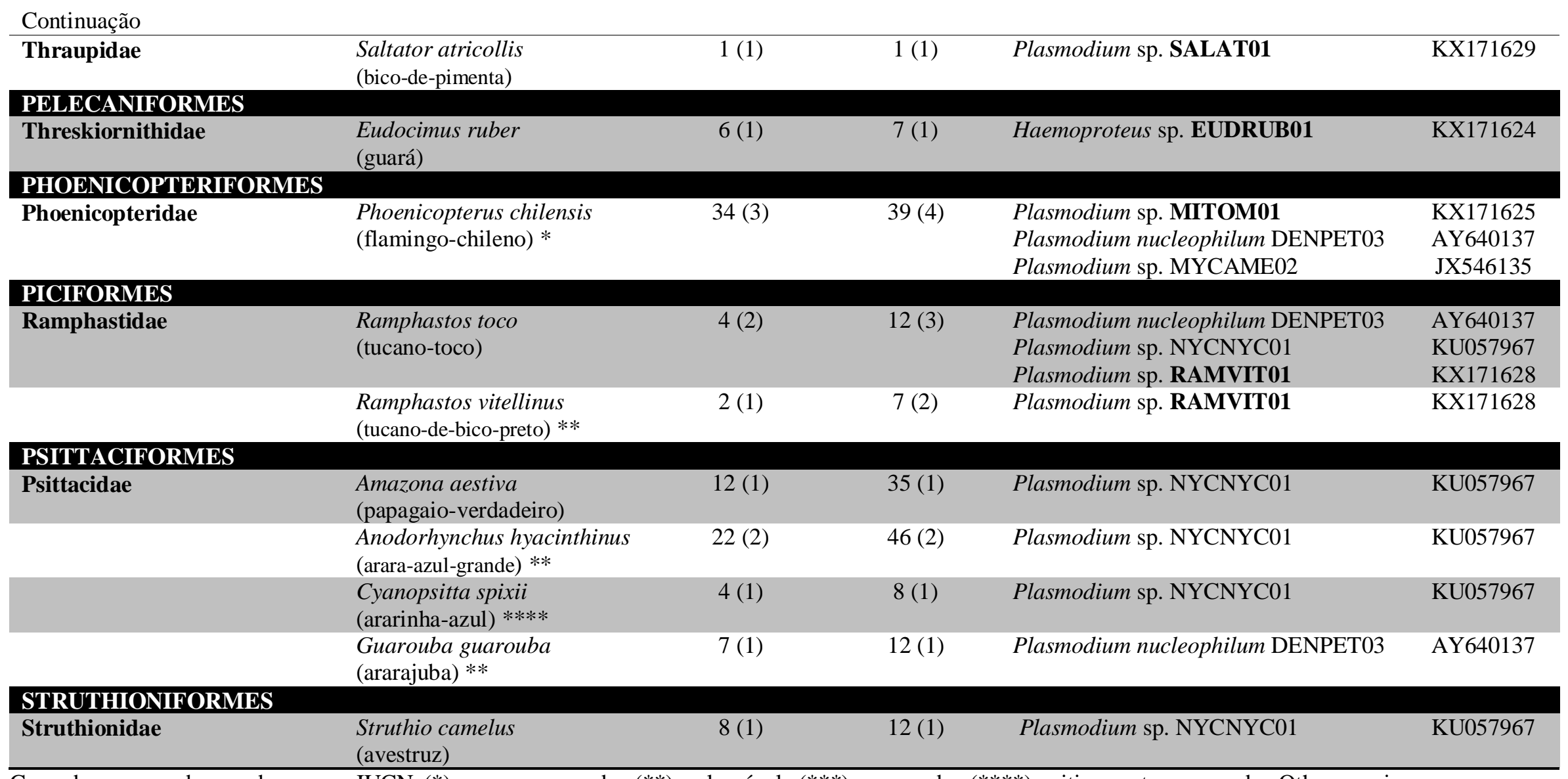

Grau de ameaça de acordo com a IUCN (*) quase ameaçado, (**) vulnerável, (***) ameaçado, (****) criticamente ameaçado. Other species are classified as Least Concern. 
No total, foram positivos $79(13,3 \%)$ animais adultos amostrados e $6(7,1 \%)$ animais jovens, sem diferenças estatisticamente significantes $\left(x^{2}=0,102, p=0,81\right)$. Com relação ao sexo dos animais, $32(11,7 \%)$ animais positivos eram fêmeas, 27 $(9,6 \%)$ eram machos e em $26(21,3 \%)$ o sexo não foi determinado. Não houve diferenças significativas na positividade em relação ao sexo ou idade.

Dentre os animais positivos foi verificado o tempo de vida em cativeiro. A grande maioria (72,9\%) vivia na FPZSP há mais de 10 anos; 18,8\% vivia entre 5 e 10 anos; $5,9 \%$ vivia entre 1 e 5 anos e 2,4\% vivia há menos de um ano quando foram amostrados. O tempo de permanência em cativeiro por mais de 10 anos mostrou associação estatisticamente significativa com a positividade $(p<0,005)$. Verificou-se também que $39(45,9 \%)$ animais vieram a óbito durante o estudo, $1(1,2 \%)$ estava desaparecido, 3 (3,5\%) foram transferidos para outras instituições e $42(49,4 \%)$ ainda estavam vivos ao término do estudo.

Também foi verificada a origem dos animais positivos: $57(67,1 \%)$ nasceram na FPZSP, 9 (10,6\%) vieram de outras instituições dentro do Estado de São Paulo, 7 $(8,2 \%)$ foram doados para o Zoológico, 7 (8,2\%) vieram de instituições localizadas em outros estados (Maranhão, Pernambuco, Paraná, Rondônia e Rio Grande do Sul), $3(3,5 \%)$ foram apreendidos por órgãos federais e estaduais e $2(2,3 \%)$ vieram de fora do país (Filipinas e Alemanha).

\subsection{Resultados morfológicos e moleculares}

Ao todo, 1230 amostras sanguíneas $(98,1 \%)$ foram testadas por microscopia e técnicas moleculares. As outras 24 amostras $(1,9 \%)$ possuíam somente esfregaço sanguíneo e foram todas negativas. Das 127 amostras positivas por PCR (10,1\%), 61 (48\%) possuíam esfregaços sanguíneos com parasitemia para Plasmodium/Haemoproteus e outras 7 amostras (5,5\%) não possuíam esfregaços sanguíneos. As parasitemias variaram entre $<0,01 \%$ e $6,39 \%$.

Após a análise dos resultados de sequenciamento foi possível identificar 16 linhagens de parasitas, sendo 14 de Plasmodium spp. e 2 de Haemoproteus spp. 
(Gráfico 5). Esses resultados moleculares revelam a presença de 83 indivíduos positivos para Plasmodium e dois indivíduos positivos para Haemoproteus.

A análise dos 61 esfregaços positivos mostrou a ocorrência de infecções mistas por Plasmodium e Haemoproteus em 11 amostras (18,0\%), provenientes de seis cisnes-negros (Cygnus atratus), com a presença da mesma linhagem de Plasmodium (NYCNYC01). Diagnóstico molecular foi incapaz de detectar essas coinfecções, uma vez que apenas uma sequência foi obtida por amostra utilizando esta metodologia. Também foi verificada a presença de uma amostra de um indivíduo de Saltator atricolis com infecção mista por duas espécies de Plasmodium, embora apenas uma linhagem (SALAT01) tenha sido detectada por PCR.

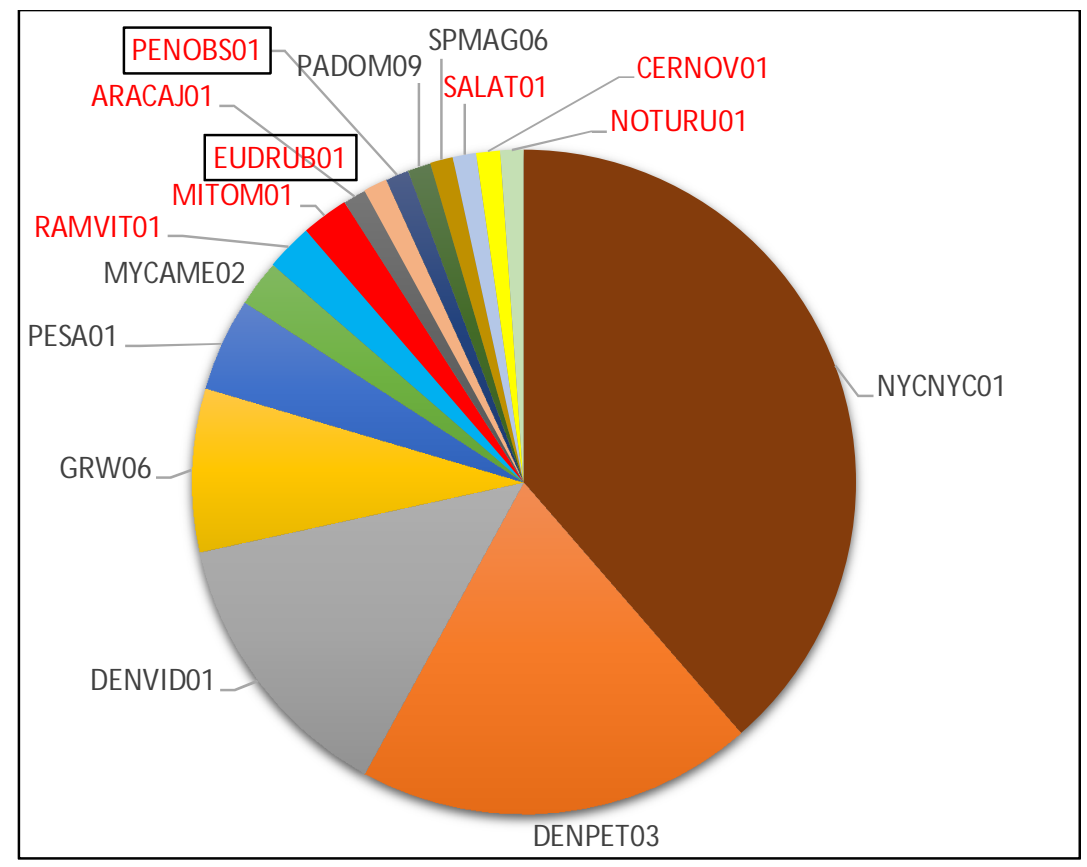

Gráfico 5 - Prevalência das linhagens encontradas nos animais cativos. Novas linhagens são destacadas em vermelho. Linhagens de Haemoproteus sp. são mostradas em caixas, as demais pertencem a Plasmodium sp.

As diferentes linhagens encontradas apresentaram distribuição desigual nas Ordens amostradas. Anseriformes apresentou 8 diferentes linhagens, seguido por Galliformes com 7 linhagens, Phoenicopteriformes e Piciformes com 3 linhagens cada, Passeriformes e Psittaciformes com 2 linhagens cada. Em outras Ordens foram 
registradas somente uma linhagem: Accipitriformes, Cathartiformes, Gruiformes, Cuculiformes, Pelecaniformes e Struthioniformes. Anatidae e Cracidae foram as Famílias com maior diversidade de linhagens (Gráficos 6 e 7).

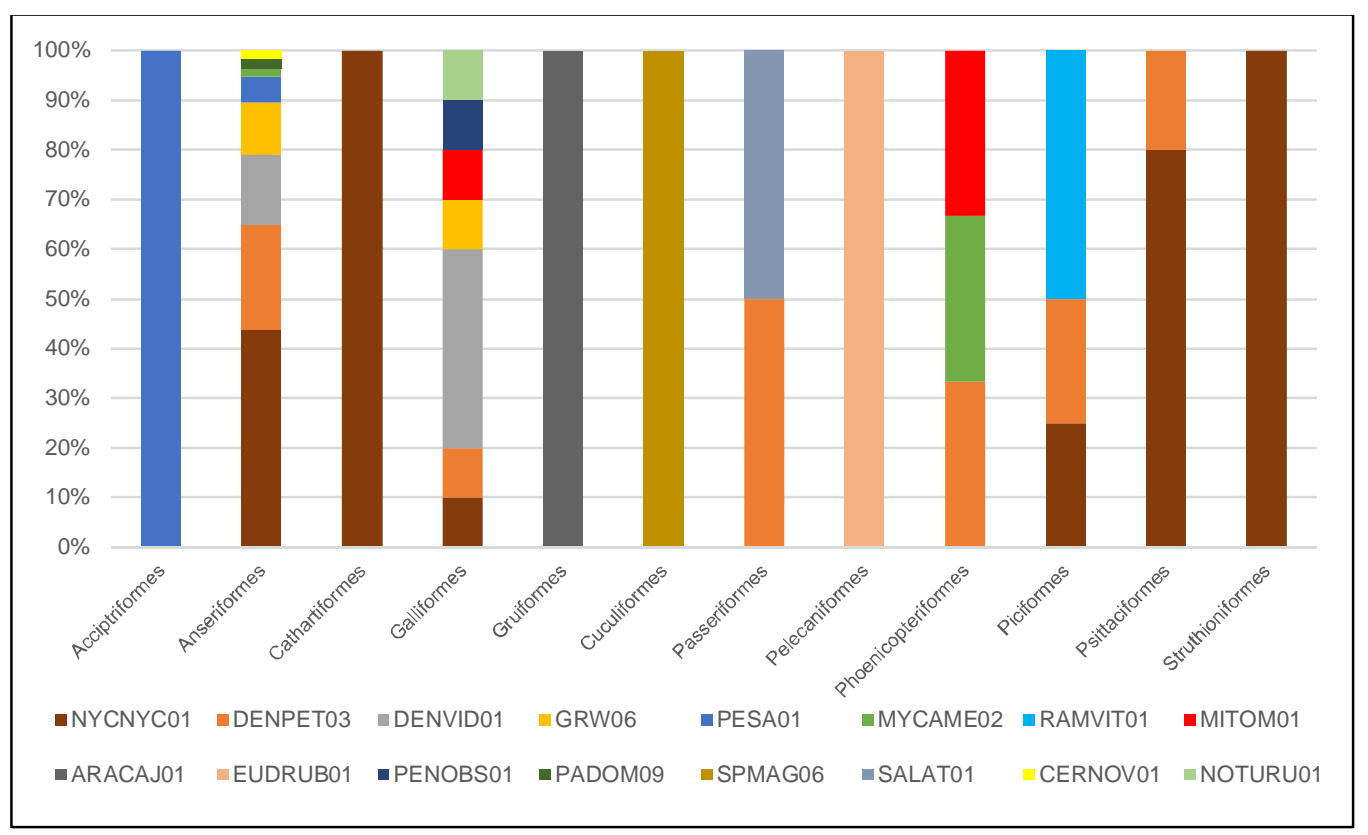

Gráfico 6 - Diversidade de linhagens encontradas por Ordem.

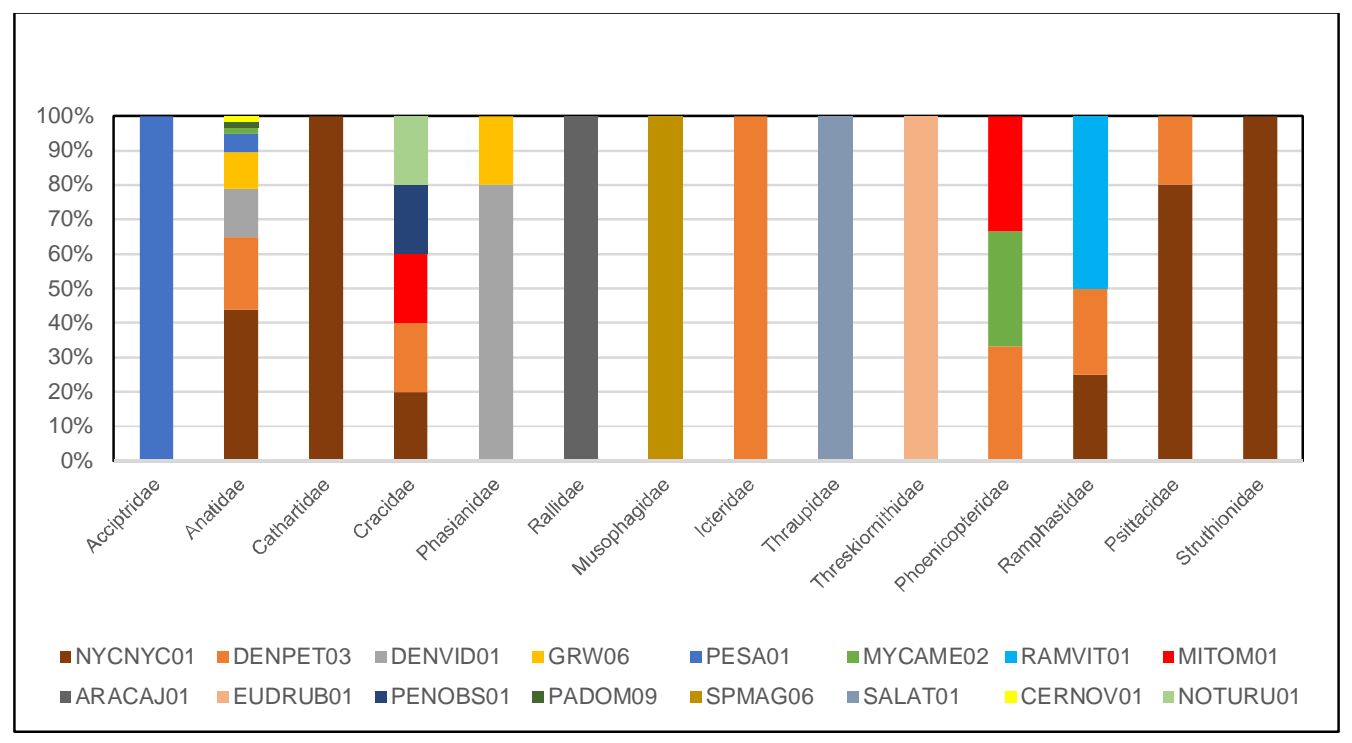

Gráfico 7 - Diversidade de linhagens encontradas por Família. 


\subsubsection{Linhagens de Plasmodium spp.}

NYCNYC01 foi a linhagem com maior prevalência, sendo encontrada em uma maior diversidade de espécies (54 amostras de 34 indivíduos de 16 espécies). No total, $23(42,6 \%)$ amostras apresentaram parasitemia com 11 (47,8\%) infecções mistas por Plasmodium sp. e Haemoproteus sp. Na análise filogenética, NYCNYC01 ficou agrupada com PESA01, com a qual possui similaridade de 99\% e ambas ficaram agrupadas com outras sequências do subgênero Haemamoeba. Essa linhagem possui merontes com citoplasma abundante (Figura 9, a-c) e gametócitos predominantemente arredondados (Figura 9, d), mas gametócitos alongados podem também estar presentes. Além disso, os gametócitos podem ou não deslocar o núcleo do eritrócito infectado (Figura 9, a-d). PESA01 também foi encontrada no local de estudo, em três espécimes de Anatidae e um espécime de Accipitridae. Somente um dos indivíduos de Anatidae apresentou parasitemia (0,3\%), com presença de merontes, mas não foi possível identificar morfologicamente a espécie.

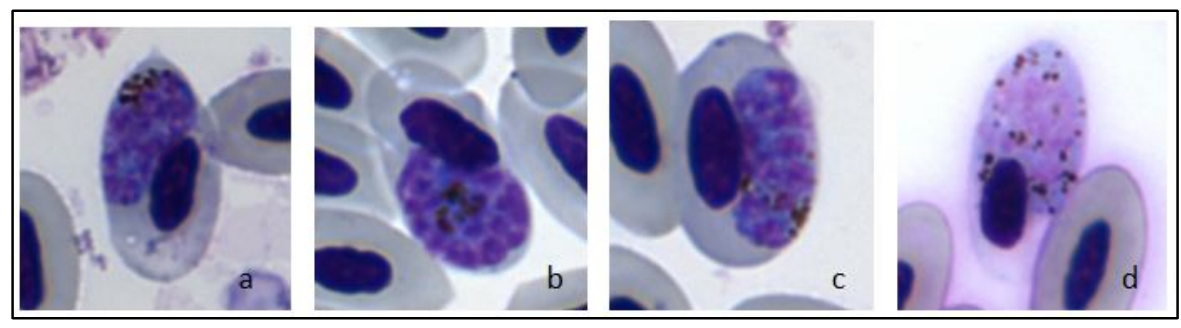

Figura 9 - Fotomicrografia de Plasmodium sp. linhagem NYCNYC01 visualizado em esfregaço sanguíneo obtido de Cygnus atratus. Merontes (a-c) contendo abundante citoplasma e grande quantidade de merozoítos, capazes de deslocar o núcleo do eritrócito infectado. Microgametócito (d) (Fotos: Carolina Chagas).

A segunda linhagem de maior frequência foi DENPET03, pertencente a $P$. nucleophilum (Figura 10), encontrada em 28 amostras de 17 indivíduos e 6 espécies diferentes. As Famílias positivas foram Anatidade (Anseriformes), Cracidae (Galliformes), Icteridae (Passeriformes), Phoenicopteridae (Phoenicopteriformes), Psittacidae (Psittaciformes) e Ramphastidae (Piciformes). Este parasita apresenta 
caráter nucleofílico, sendo encontrado próximo ao núcleo do eritrócito infectado desde os estágios mais jovens (Figura 10, a-f). Também possui merontes com pouco citoplasma, contendo 6 a 8 merozoítos cada (Figura 10, b-c). Os gametócitos são alongados com menos de 10 grânulos pigmentares (Figura 10, d-f). Vacúolos e glóbulos refráteis são vistos em alguns trofozoítos e merontes ${ }^{10}$.

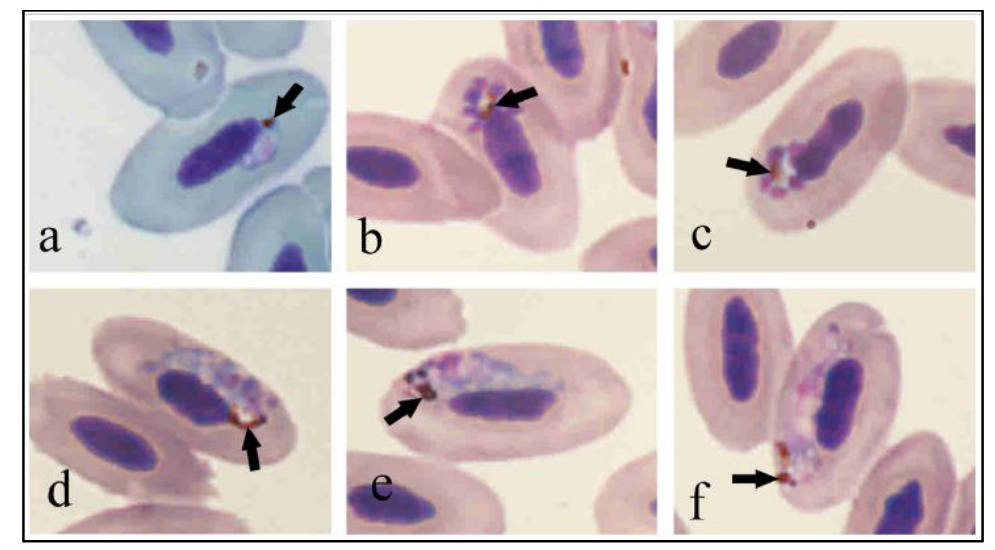

Figura 10 - Fotomicrografia de $P$. nucleophilum visualizado em esfregaço sanguíneo obtido de Alopochen aegyptiacus. Trofozoíto (a), merontes (b-c), macrogametócitos (d-e), microgametócito (f). Setas indicam a hemozoína. Adaptado de Chagas et al. (2013)(APÊNDICE B).

DENVID01 foi a linhagem com a terceira maior prevalência, presente em Anatidae e Phasianidae. Apresenta glóbulos refráteis em alguns merontes, que possuem entre 5 a 7 merozoítos (Figura 11, c). Os gametócitos maduros possuem formato ameboide (Figura 11, e-f, j-l). Nos microgametócitos os pigmentos maláricos se unem formando um grande pigmento (Figura 11, j-1), enquanto que nos macrogametócitos possuem um padrão aleatório de distribuição pelo citoplasma do parasita (Figura 11, e-f). Além disso, os gematócitos jovens possuem prolongamentos (Figura 11, g-i). Na análise filogenética esta linhagem se agrupa juntamente com outras do subgênero Novyella. 


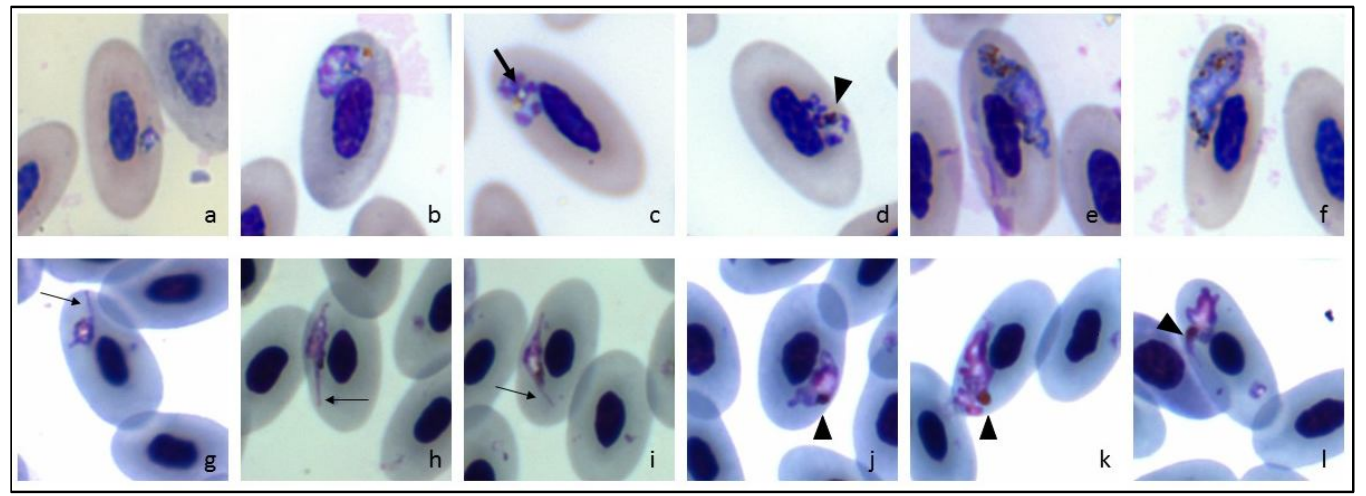

Figura 11 - Fotomicrografia de Plasmodium sp. linhagem DENVID01 visualizado em esfregaços sanguíneos obtidos de Cygnus atratus e de Pavo muticus. Cygnus atratus (a-f) e Pavo muticus (g-l). Trofozoíto (a), meronte jovem (b), merontes maduros (c-d), macrogametócitos (e-f), gametócitos imaturos (g-i), microgametócitos (j-l). Glóbulo refrátil (seta grossa), prolongamentos em gametócitos (seta fina), pigmento malárico (cabeça de seta) (Fotos: Carolina Chagas).

A linhagem GRW06, pertencente a $P$. (Huffia) elongatum, foi encontrada em Anatidae (Anseriformes) e Phasianidae (Galliformes). Apesar da ausência de parasitas maduros, foi possível confirmar a espécie morfologicamente, devido a presença de trofozoítos e merontes em eritroblastos (Figura 12, a-e) e de gametócitos em eritrócitos maduros (Figura 12, f). Todas as amostras de animais cativos com $P$. elongatum apresentaram sequências com $100 \%$ de similaridade com esta linhagem. $\mathrm{Na}$ análise filogenética, este parasita formou um clado separado dos demais subgêneros de Plasmodium.

Dois indivíduos, um de Cygnus atratus e um de Phoenicopterus chilensis apresentaram linhagens com 100\% de similaridade para MYCAME02. As duas amostras possuíam esfregaços sanguíneos negativos.

A nova linhagem RAMVIT01 foi encontrada somente em Ramphastidae (Piciformes) (um indivíduo de Ramphastos vitellinus e um indivíduo de Ramphastos toco) e apresentou 96\% de similaridade com TFUS06, Plasmodium unalis. Apresenta merontes característicos do subgênero Novyella (Figura 13, a-e) e gametócitos localizados na região polar do eritrócito infectado e com núcleo proeminente (Figura $13, \mathrm{f}-\mathrm{g})$. 
Outra nova linhagem de Plasmodium sp., MITOM01, foi encontrada em Mitu tomentosa (Cracidae) e Phoenicopterus chilensis (Phoenicopteridae), sendo um indivíduo de cada espécie. Devido à baixa parasitemia e ausência de formas parasitária maduras não foi possível descrever a espécie morfologicamente.

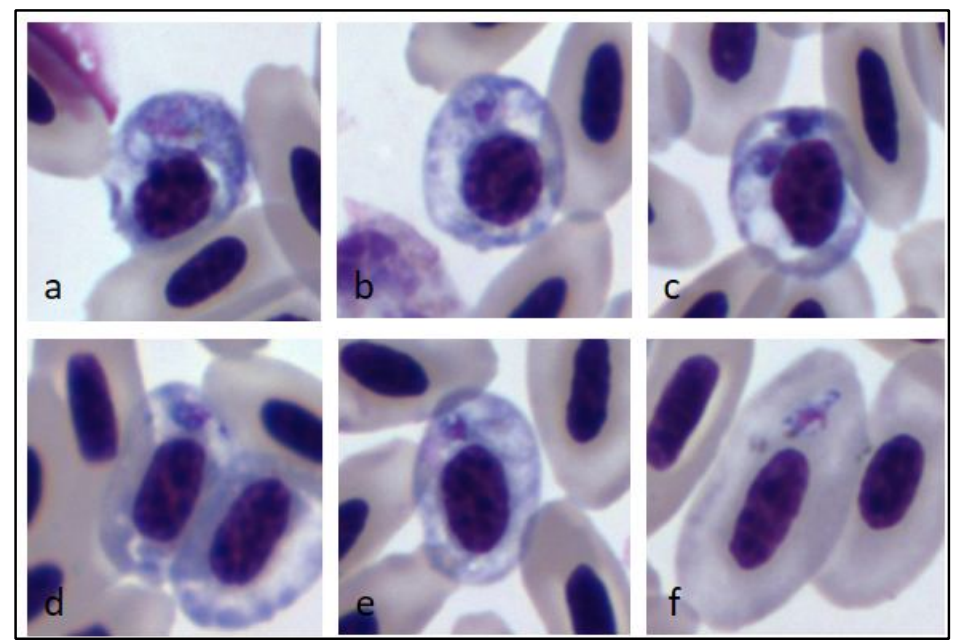

Figura 12 - Fotomicrografia de $P$. elongatum visualizado em esfregaço sanguíneo obtido de Cygnus atratus. É possível verificar a presença de merontes (a) e trofozoítos jovens em eritroblastos (b-e), e de gametócito jovem em eritrócito maduro (f) (Fotos: Carolina Chagas).

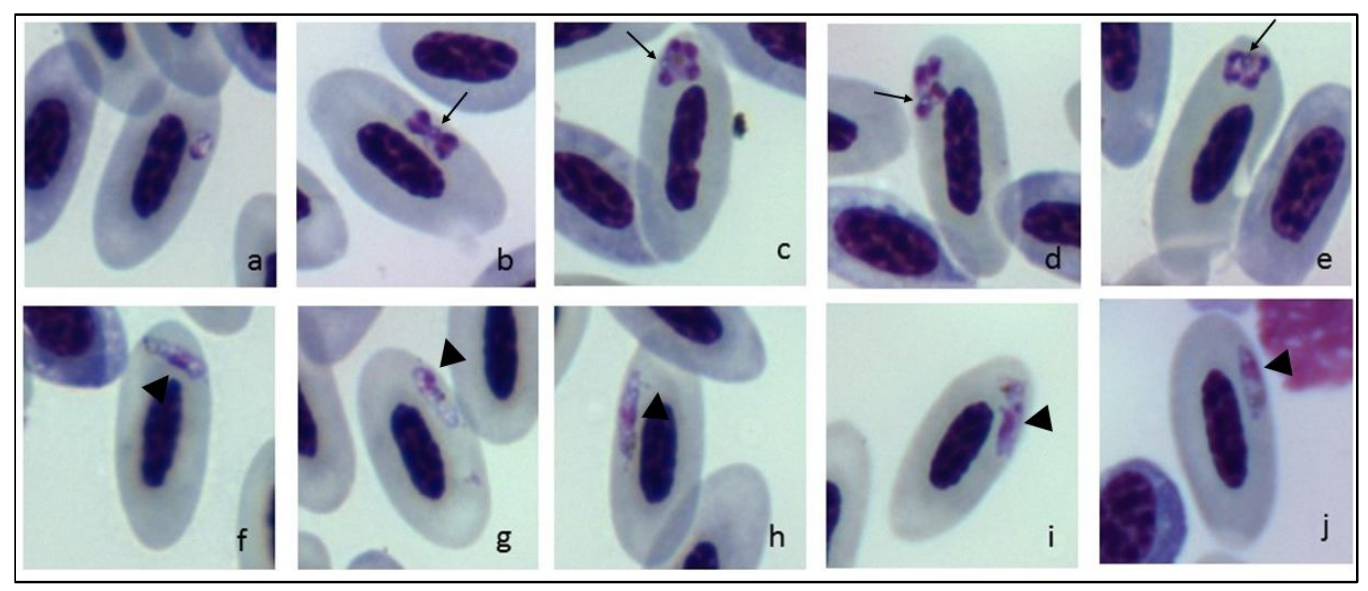

Figura 13 - Fotomicrografia de Plasmodium sp. linhagem RAMVIT01 visualizado em esfregaço sanguíneo obtido de Ramphastos toco. Trofozoítos (a), merontes (b-e), gametócitos imaturos (f-j). Glóbulos refráteis (seta fina), núcleo proeminente em gametócitos (cabeça de seta) (Fotos: Carolina Chagas). 
A linhagem ARACAJ01, também descrita por este estudo, foi encontrada em um único indivíduo de Aramides cajanea. A amostra apresentou alta parasitemia (2,36\%). Apesar disso, somente formas jovens do parasita foram encontradas, impossibilitando a descrição morfológica. Esta linhagem possui características morfológicas compatíveis com o subgênero Novyella, tais como: merontes com poucos merozoítos e pouco citoplasma (Figura 14, a-d). Na árvore filogenética ARACAJ01 ficou agrupada com outras do subgênero Novyella.

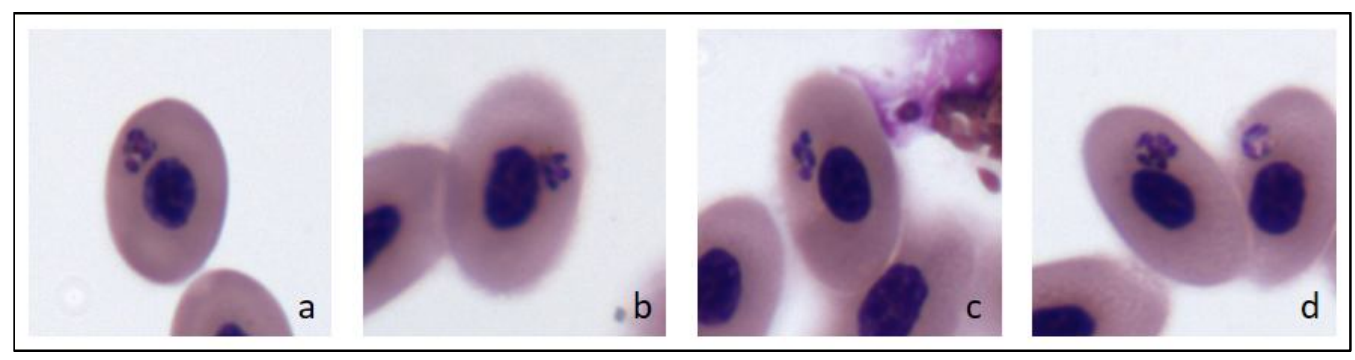

Figura 14 - Fotomicrografia de Plasmodium sp. linhagem ARACAJ01 visualizado em esfregaço sanguíneo obtido de Aramides cajanea. Meronte jovem (a) e maduros (b-d) (Fotos: Carolina Chagas).

PADOM09 foi encontrada em um único indivíduo de Anser cygnoides. O esfregaço sanguíneo deste animal possuía baixa parasitemia $(<0,01 \%)$ e somente estágios de desenvolvimento muito jovens, não sendo possível a identificação morfológica do parasita.

A linhagem SPMAG06 de Plasmodium sp. foi encontrada em um indivíduo da espécie Musophaga violacea (Musophagiformes: Musophagidae). Não foram encontrados parasitas no esfregaço sanguíneo.

SALAT01, uma nova linhagem, foi encontrada em um exemplar de Saltator atricolis e na inferência filogenética ficou localizada juntamente com outras linhagens de $P$. (Novyella) sp. Foi possível confirmar morfologicamente que este animal possuía infecção mista por dois subgêneros de Plasmodium. A presença de $P$. (Novyella) sp. é confirmada pelos merontes com citoplasma escasso e com poucos merozoítos (Figura 15, a-e). P. (Haemamoeba) sp. foi detectado pela presença de gametócitos maduros grandes, arredondados, deslocando o núcleo da célula infectada 
(Figura 15, h-j), bem como merontes imaturos com muito citoplasma, também capazes de deslocar o núcleo do eritrócito infectado (Figura 15, f-g). Entretanto, no cromatograma do sequenciamento do produto de PCR obtido nessa amostra, picos duplos não foram visualizados.

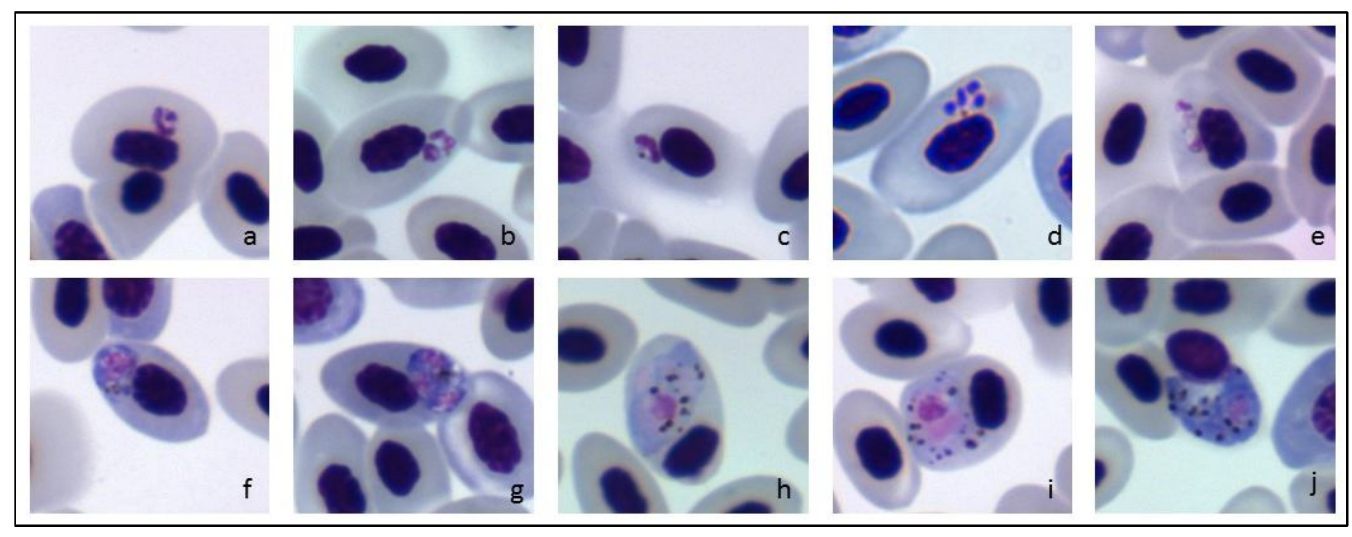

Figura 15 - Fotomicrografia de Plasmodium sp. linhagem SALAT01 visualizado em esfregaço sanguíneo obtido de Saltator atricolis. P. (Novyella) sp. (a-e), merontes maduros (a-d) e gametócito jovens (e). $P$. (Haemamoeba) sp. (f-j), merontes imaturos (f-g), microgametócitos maduros (h-i), macrogametócito maduro (j) (Fotos: Carolina Chagas).

Encontramos uma sequência com 98\% de similaridade com DENVID01, em Cereopsis novahollandiae, que foi então denominada CERNOV01. A parasitemia encontrada na amostra era baixa $(<0,01 \%)$ e com ausência de algumas fases do ciclo ou com parasitas em estágios ainda muito jovens (Figura 16, a-d), impedindo a identificação morfológica da linhagem.

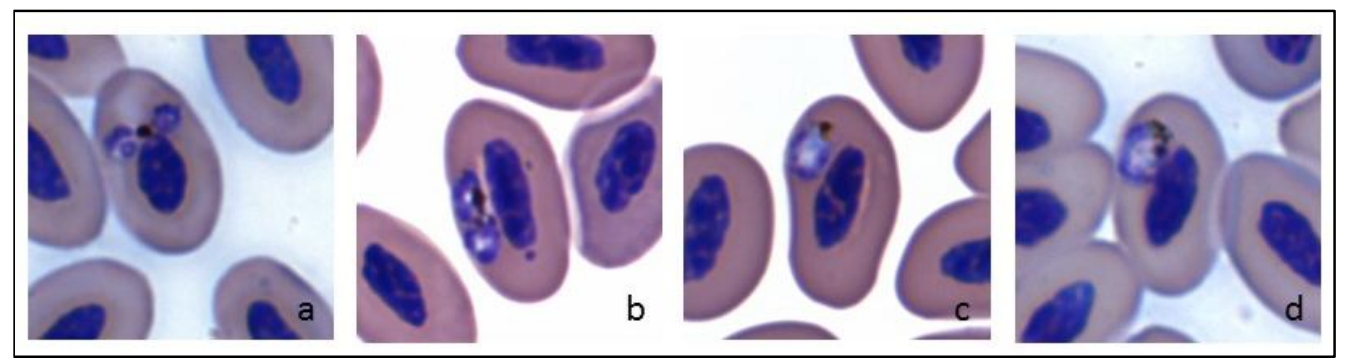

Figura 16 - Fotomicrografia de Plasmodium sp. linhagem CERNOV01 visualizado em esfregaço sanguíneo obtido de Cereopsis novahollandiae. Merontes (a-b) gametócitos jovens (c-d) (Fotos: Carolina Chagas). 
A linhagem NOTURU01 foi encontrada em um único exemplar de Nothocrax urumutum, apresentou 99\% de similaridade com a linhagem CINCHA01. Esse indivíduo não possuía esfregaço sanguíneo e, portanto, não foi possível descrever morfologicamente essa linhagem.

Para melhor compreender a distribuição de haplótipos encontrados para as linhagens de Plasmodium (Haemamoeba) sp., duas redes de haplótipos foram construídas com as sequências obtidas neste estudo e as sequências disponíveis no banco de dados do MalAvi.

Primeiramente, as linhagens foram classificadas de acordo com a Ordem do hospedeiro no qual foram encontradas (Figura 18). Os resultados mostraram grande dominância de sequências descritas em Passeriformes, com algumas linhagens descritas somente nesta Ordem. Poucas linhagens (com notável participação da linhagem mais generalista encontrada neste estudo e sua variante) foram observadas em mais de uma Ordem. Em seguida, as linhagens foram classificadas de acordo com o continente em que foram encontradas (Figura 19). Duas linhagens encontradas neste estudo, NYCNYC01 e PESA01 mostraram limitada distribuição geográfica, sendo descritas somente na América do Sul e do Norte. Pôde-se observar que linhagens encontradas na América do Sul são normalmente também detectadas na América do Norte, mas raramente em outras regiões geográficas, com exceção de SGS1 e GRW04, linhagens de P. relictum conhecidas por possuir ampla distribuição geográfica. Em termos de passos mutacionais, NYCNYC01 e PESA01 estão mais proximamente relacionadas a linhagens descritas na Ásia do que nas demais regiões geográficas.

Figura 17 (próxima página) - Filogenia bayesiana das linhagens do gene citocromo b das espécies de Plasmodium de parasitas hemosporídeos de aves. As linhagens registradas nesse trabalho são apresentadas em vermelho. Os nomes das linhagens são apresentados após os nomes das espécies de parasitas. Números de acesso do GenBank das linhagens são fornecidos antes dos nomes das espécies de parasitas. Valores de suporte dos nodos (em porcentagem) indicam probabilidades posteriores dos clados 


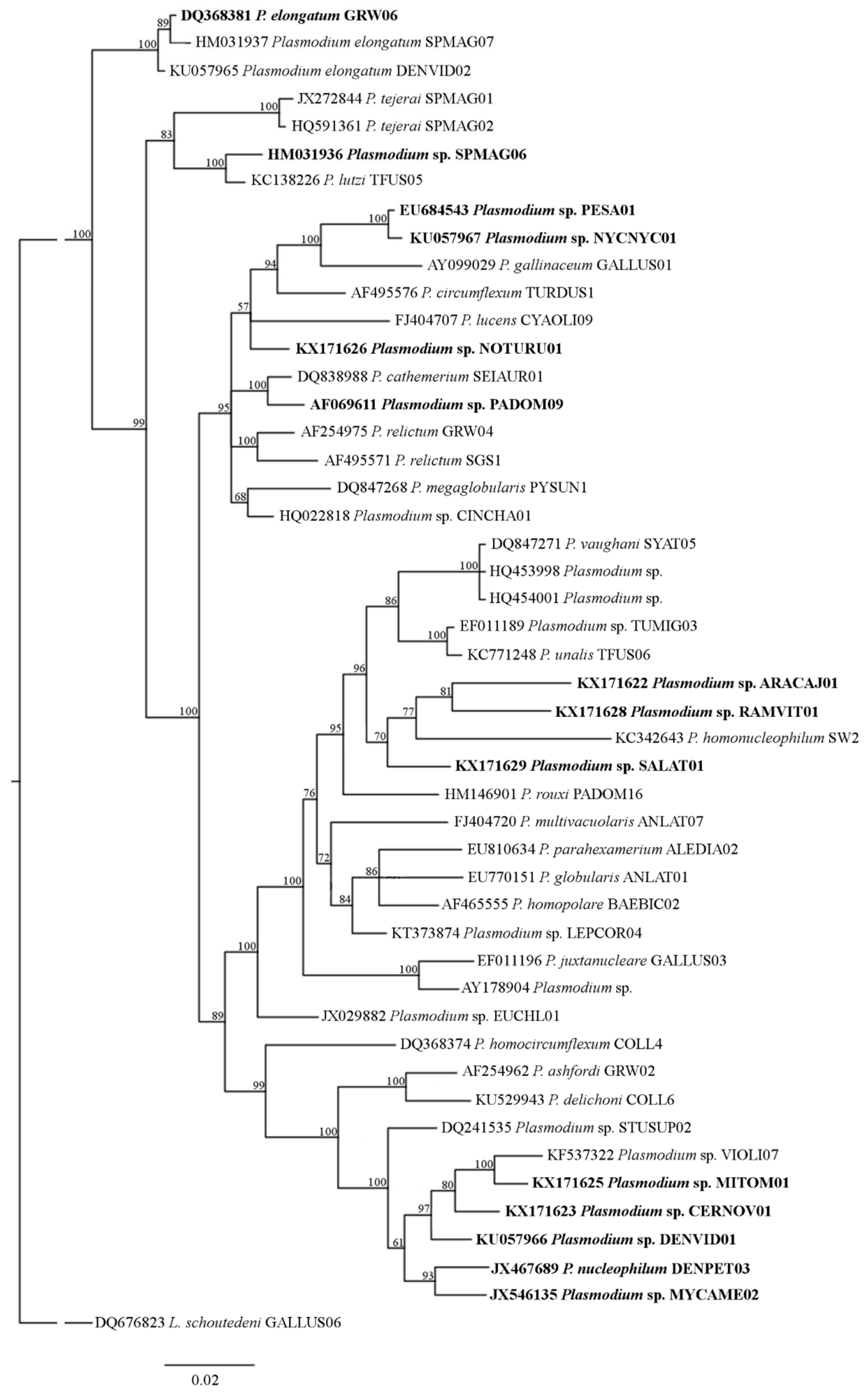


Phenotype

$\square$ CHARADRIIFORMES

$\square$ COLUMBIFORMES

$\square$ ACCIPTRIFORMES

$\square$ ANSERIFORMES

$\square$ PASSERIFORMES

$\square$ CICONIFORMES

$\square$ CATHARTIFORMES

$\square$ PICIFORMES

$\square$ PSITACIFORMES

STRUTHIONIFORME

$\square$ STRIGIFORMES

SPHENISCIFORMES

$\square$ DIPTERA

$\square$ GALLIFORMES

$\square$ BUCEROTIFORMES

$\square$ PELECANIFORMES

$\square$ GRUIFORMES

$\square$ PROCELLARIFORME

$\square$ TROCHILIFORMES

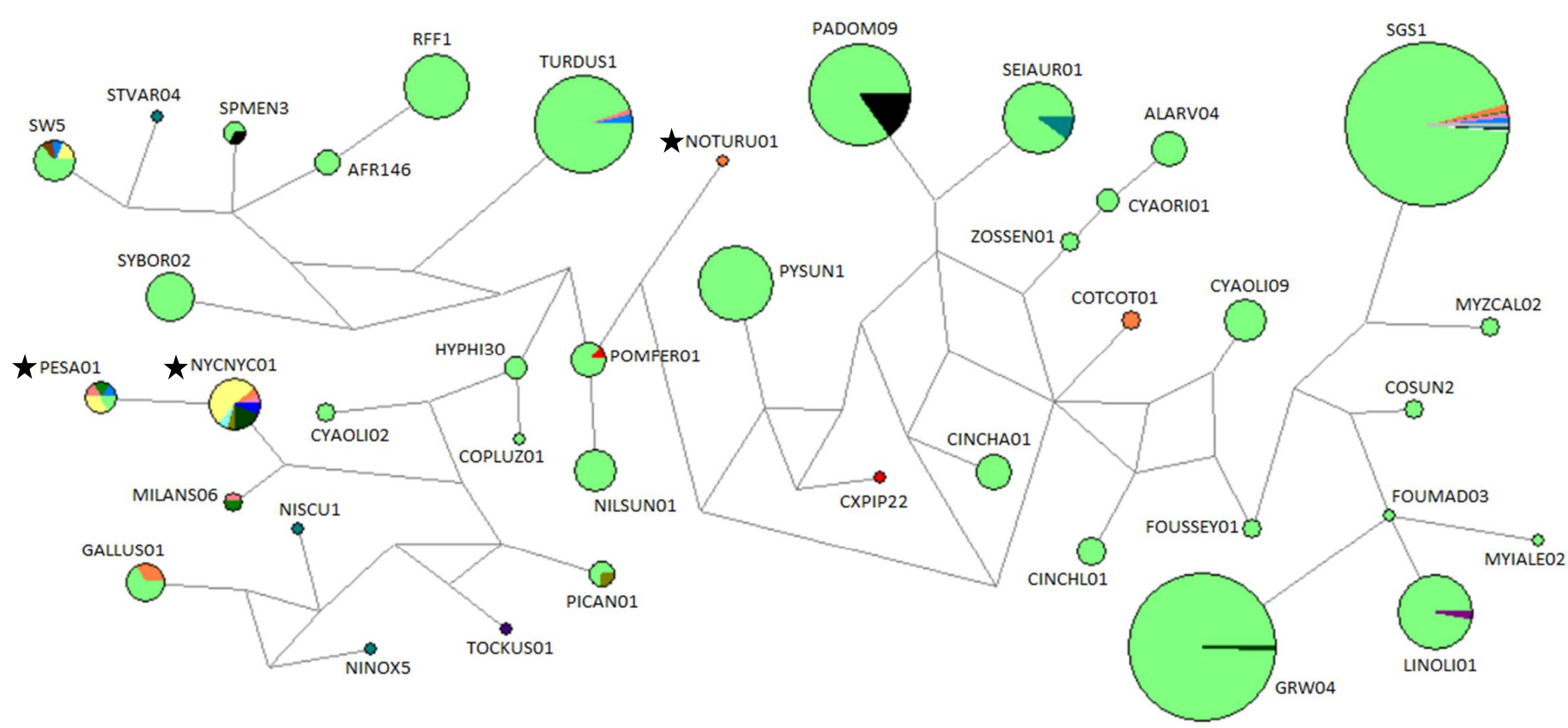

Figura 18 - Rede de haplótipos segundo a Ordem dos hospedeiros. As linhagens indicadas com estrelas foram encontradas neste estudo. Espécies de Plasmodium presentes neste estudo: P. relictum (GRW04 e SGS1), P. gallinaceum (GALLUS01), $P$. cathemerium (SEIAUR01), P. circumflexum (TURDUS01 e SW5), P. lucens (CYAOLI09), P. megaglobularis (PYSUN1). 
Geography

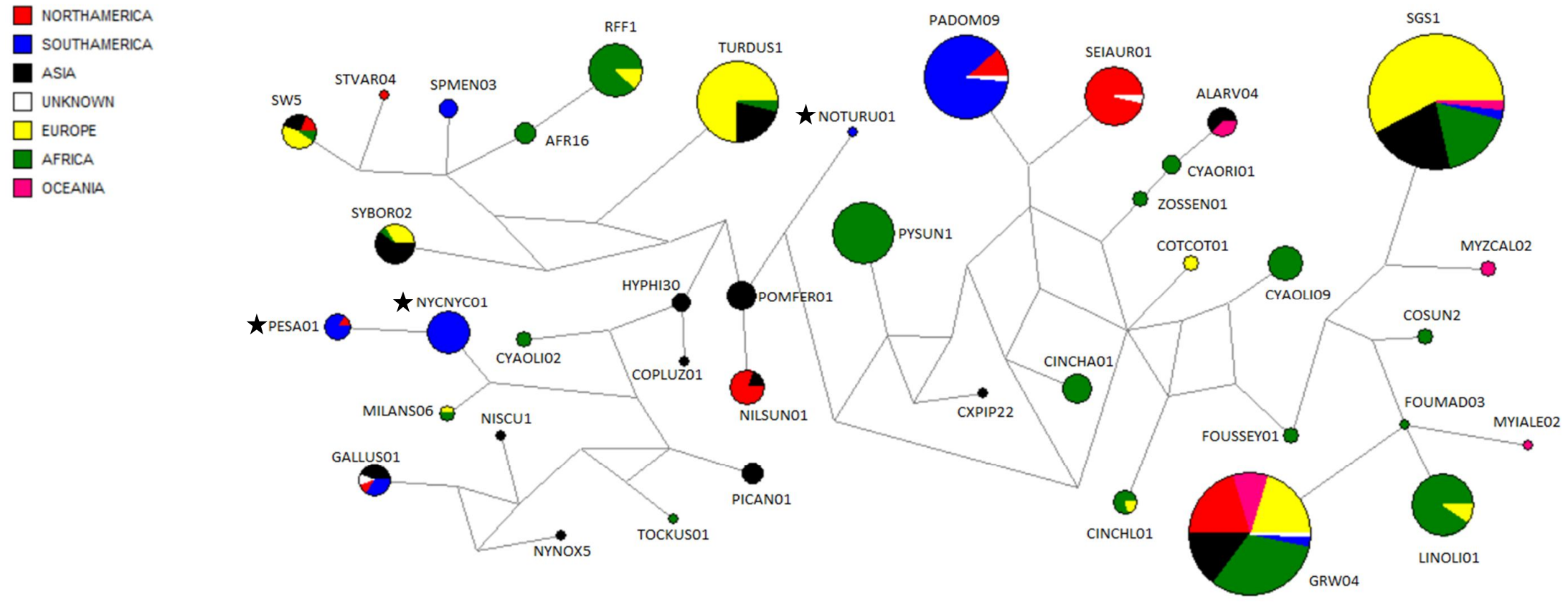

Figura 19 - Rede de haplótipos segundo a localização geográfica, por continente, de ocorrência das linhagens. As linhagens indicadas com estrelas foram encontradas neste estudo. Espécies de Plasmodium presentes neste estudo: P. relictum (GRW04 e SGS1), $P$. gallinaceum (GALLUS01), $P$. cathemerium (SEIAUR01), $P$. circumflexum (TURDUS01 e SW5), $P$. lucens (CYAOLI09), P. megaglobularis (PYSUN1). 


\subsubsection{Linhagens de Haemoproteus spp.}

EUDRUB01 foi encontrada em um indivíduo de Eudocimus ruber, em baixa parasitemia $(0,01 \%)$, e apresentou 99\% de similaridade com HALMAL01. Não foi possível identificar morfologicamente a espécie de Haemoproteus presente na amostra, devido à pequena quantidade de parasitas. Apesar disso, é possível notar a presença de algumas características morfológicas marcantes, como o posicionamento do núcleo nos macrogametócitos, sempre no lado oposto ao do núcleo do eritrócito infectado (Figura 20, a-d) e a presença de agregados de hemozoína em região polar dos microgametócitos (Figura 20, e-f).

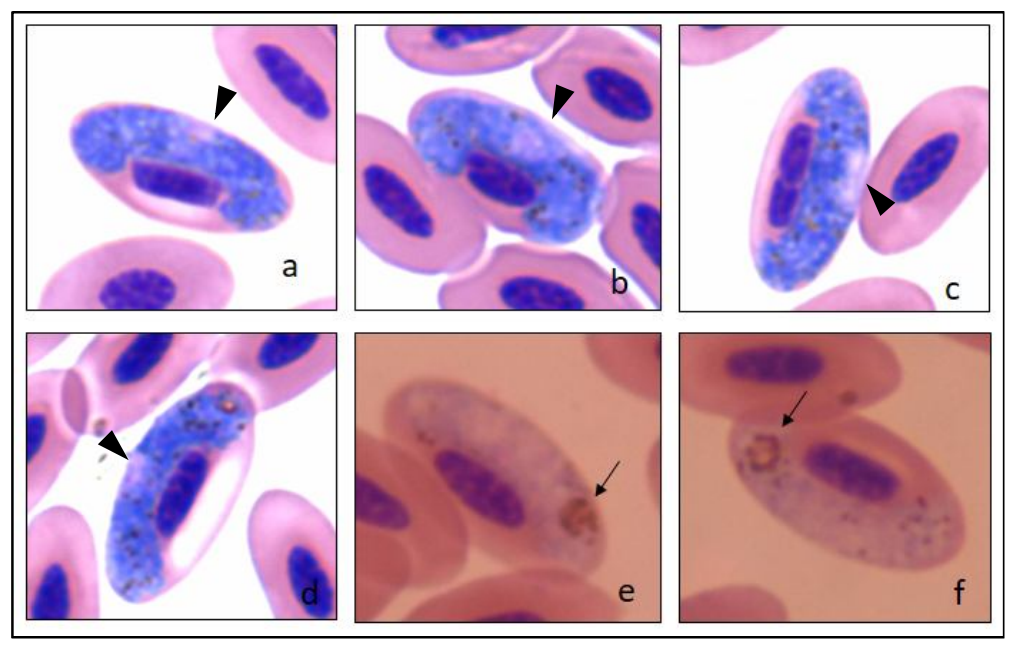

Figura 20 - Fotomicrografia de Haemoproteus sp. linhagem EUDRUB01 visualizado em esfregaço sanguíneo obtido de Eudocimus ruber. Gametócito jovem (a), macrogametócitos (b-d) e microgametócitos (ef). Posicionamento do núcleo nos macrogametócitos (cabeça de seta) e acúmulo de pigmento em um arranjo arredondado (seta) (Fotos: Carolina Chagas).

A linhagem PENOBS01 foi encontrada em Penelope obscura, e apresentou 96\% de similaridade com a linhagen MILANS03. A parasitemia era baixa $(<0,01 \%)$ e o animal teve amostra colhida uma única vez durante o projeto. Morfologicamente 
foi possível verificar a presença de gametócitos jovens arredondados (Figura 21, b), além de gametócitos alongados (Figura 21, a, c-d). Os macrogametócitos apresentam um grande vacúolo em seu citoplasma (Figura 21, a). Os grânulos de hemozoína são pequenos nos dois gametócitos e encontram-se distribuídos pelo citoplasma do parasita (Figura 21, a, c-d). Essas características permitem a confirmação morfológica da linhagem como pertencente a Haemoproteus ortalidum.

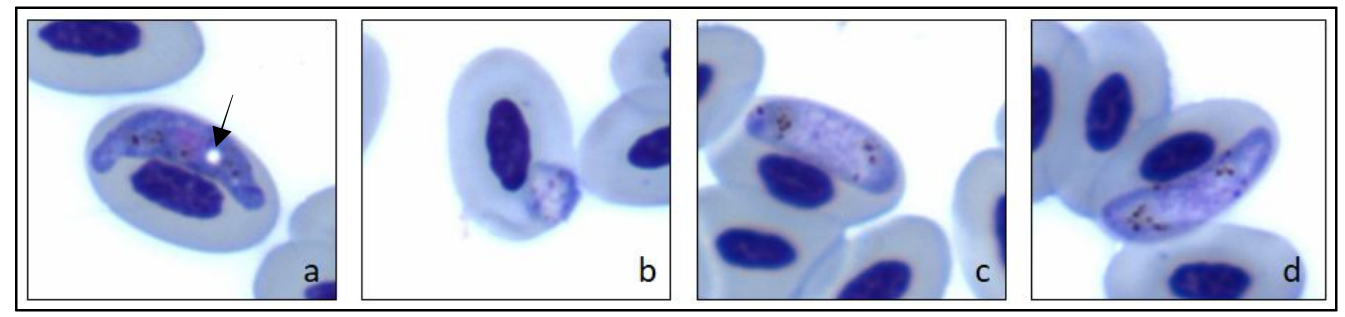

Figura 21 - Fotomicrografia de Haemoproteus ortalidum linhagem PENOBS01 visualizado em esfregaço sanguíneo obtido de Penelope obscura. Macrogametócito (a), microgametócito jovem (b) e microgametócitos maduros (c-d). Presença de vacúolo no macrogametócito (seta) (Fotos: Carolina Chagas)

Figura 22 (próxima página) - Filogenia bayesiana das linhagens do gene citocromo b das espécies de Haemoproteus de parasitas hemosporídeos de aves. As linhagens obtidas nesse trabalho são apresentadas em vermelho. Os nomes das linhagens são apresentados após os nomes das espécies de parasitas. Números de acesso do GenBank das linhagens são fornecidos antes dos nomes das espécies de parasitas. Valores de suporte dos nodos (em porcentagem) indicam probabilidades posteriores dos clados. 


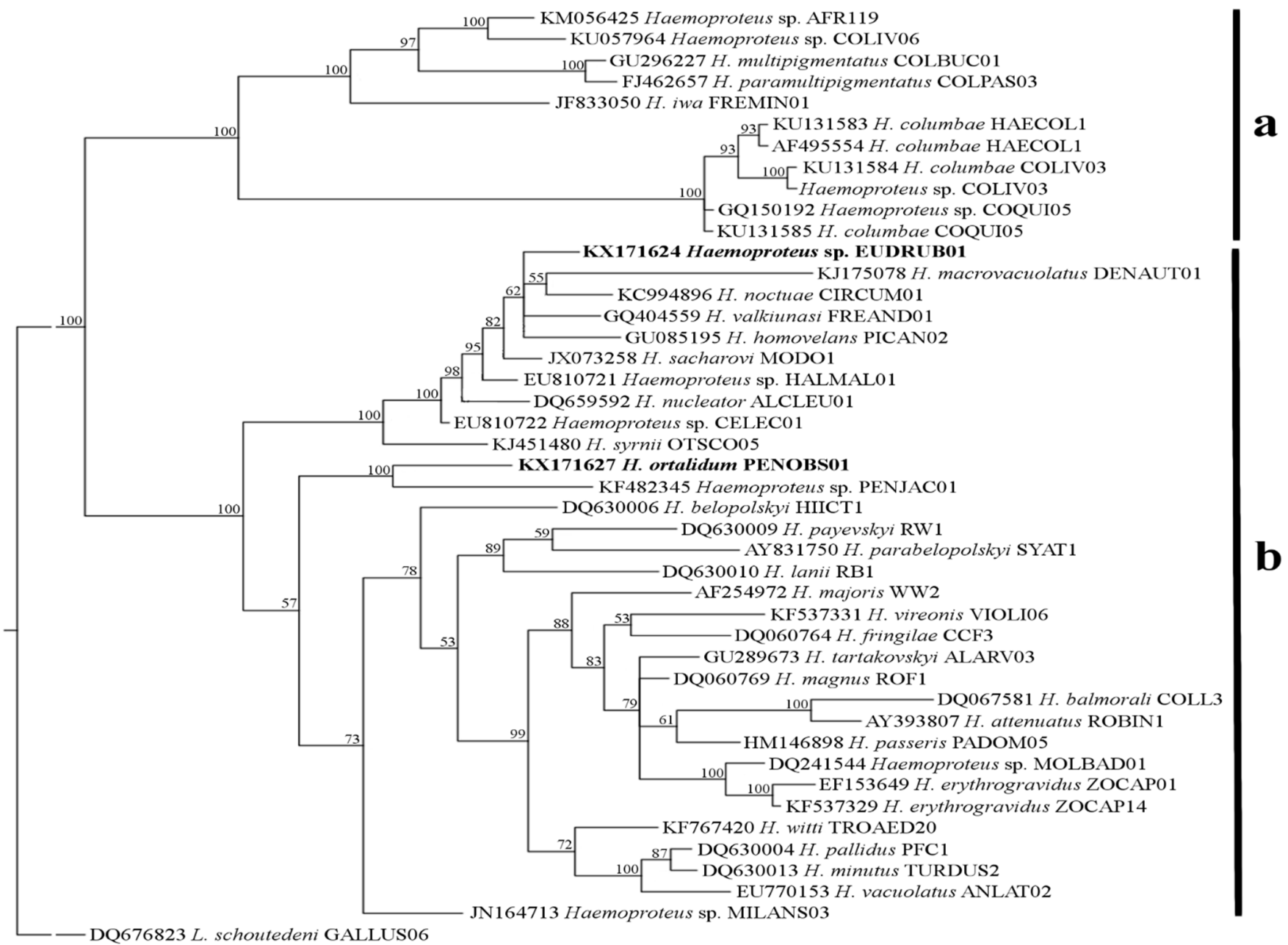

0.02 


\subsection{Sazonalidade}

Para verificar a presença de sazonalidade de infecção, cada novo caso reportado foi analisado de acordo com a data de detecção e classificado de acordo com a estação do ano. O número total de animais positivos foi avaliado dentro do total de animais amostrados em cada estação. Apesar da maior porcentagem de indivíduos positivos detectada durante o verão, não foi encontrada associação estatisticamente significante da positividade com as estações do ano $\left(x^{2}=2,17\right.$; $\mathrm{p}=0,14)($ Gráfico 8).

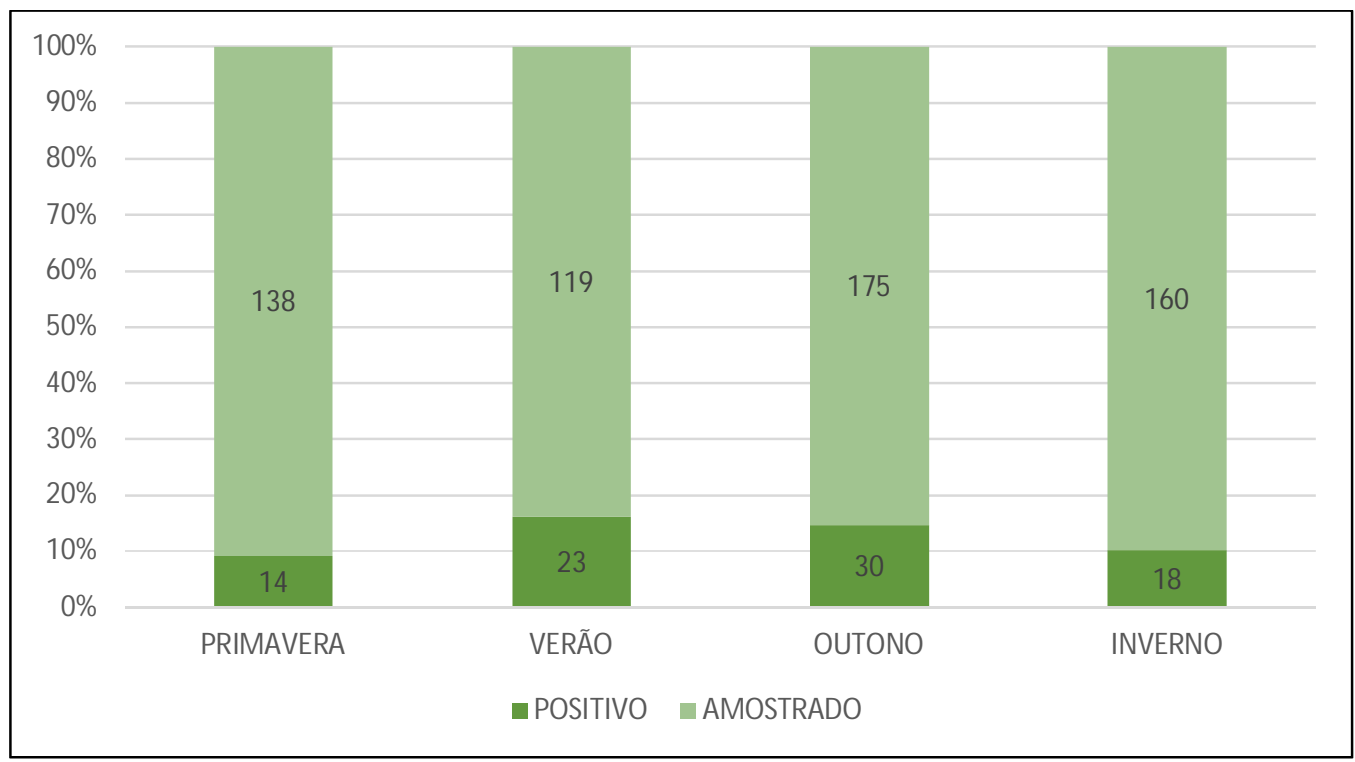

Gráfico 8 - Distribuição sazonal de animais amostrados e positivos. O número de indivíduos amostrados e positivos em cada estação é indicado em cada coluna $(n=677)$. Os dados foram combinados para todos os anos do estudo.

\subsection{Acompanhamento longitudinal}

Dos 677 indivíduos analisados, 262 (38,7\%) foram testados em mais de uma coleta no período do estudo, sendo 141 com duas coletas e 121 com três ou mais 
coletas. Desses, quatro animais tiveram entre 10 e 15 amostras colhidas. Quarenta e seis animais foram acompanhados em até oito coletas, sendo 35 negativos em todas. Doze animais apresentaram de 4 a 8 coletas (Tabela 3). É possível verificar a presença de animais que se mantiveram positivos em todas as coletas como também alguns que negativaram ao longo do estudo.

Interessantemente, duas aves foram positivas para diferentes linhagens durante o estudo: um indivíduo de $A$. cygnoides teve 4 amostras testadas, todas foram positivas, sendo que NYCNYC01 esteve presente em 3 delas e PADOM09 em uma; outro indivíduo de $R$. toco teve 5 amostras testadas, sendo duas positivas, cada uma para uma linhagem diferente (NYCNYC01 e DENPET03). 
Tabela 3 - Animais adultos com quatro a oito coletas no estudo e presença de amostras positivas.

\begin{tabular}{|c|c|c|c|c|c|c|c|c|c|c|c|c|c|c|c|c|}
\hline & \multicolumn{2}{|c|}{ COLETA1 } & \multicolumn{2}{|c|}{ COLETA2 } & \multicolumn{2}{|c|}{ COLETA3 } & \multicolumn{2}{|c|}{ COLETA4 } & \multicolumn{2}{|c|}{ COLETA5 } & \multicolumn{2}{|c|}{ COLETA6 } & \multicolumn{2}{|c|}{ COLETA7 } & \multicolumn{2}{|c|}{ COLETA8 } \\
\hline $\begin{array}{c}\text { T. variegata, M, } \\
\text { SETOR, FPZSP, } \\
>10 \text { ANOS, MORTO }\end{array}$ & $08 / 12 / 11$ & $\mathrm{~N}$ & $18 / 12 / 13$ & NYCNYC01 & $31 / 12 / 13$ & NYCNYC01 & $03 / 01 / 14$ & NYCNYC01 & $16 / 04 / 14$ & NYCNYC01 & NR & NR & NR & NR & NR & NR \\
\hline $\begin{array}{c}\text { B. urubitinga, } \mathrm{F}, \\
\text { EXP } 113, \text { RO, } \\
>10 \text { ANOS, VIVO }\end{array}$ & $02 / 04 / 12$ & $\mathrm{~N}$ & $22 / 05 / 12$ & PESA01 & $13 / 03 / 14$ & $\mathrm{~N}$ & $26 / 03 / 14$ & $\mathrm{~N}$ & $09 / 04 / 14$ & $\mathrm{~N}$ & $15 / 12 / 14$ & $\mathrm{~N}$ & NR & NR & NR & NR \\
\hline $\begin{array}{c}\text { C. atratus, } \\
\text { LAGO 70, FPZSP, } \\
\text { >10 ANOS, VIVO }\end{array}$ & $05 / 04 / 12$ & $\mathrm{~N}$ & $13 / 04 / 12$ & $\mathrm{~N}$ & $15 / 05 / 12$ & $\mathrm{~N}$ & $06 / 06 / 14$ & GRW06 & NR & NR & NR & NR & NR & NR & NR & NR \\
\hline $\begin{array}{c}\text { C. atratus, } \\
\text { LAGO 70, FPZSP, } \\
\text { 5-10 ANOS, MORTO }\end{array}$ & $12 / 04 / 12$ & DENPET03 & $14 / 05 / 12$ & DENPET03 & $23 / 05 / 12$ & DENPET03 & $11 / 07 / 12$ & DENPET03 & $31 / 07 / 12$ & DENPET03 & NR & NR & NR & NR & NR & NR \\
\hline $\begin{array}{c}\text { R. toco, } \mathrm{F}, \\
\text { EXTRA, } \\
>10 \text { ANOS, MORTO }\end{array}$ & $15 / 05 / 12$ & DENPET03 & $19 / 07 / 12$ & $\mathrm{~N}$ & $31 / 08 / 12$ & $\mathrm{~N}$ & $29 / 11 / 12$ & NYCNYC01 & $10 / 03 / 13$ & $\mathrm{~N}$ & NR & NR & NR & NR & NR & NR \\
\hline $\begin{array}{l}\text { A. aestiva, M, EXTRA, } \\
>10 \text { ANOS, VIVO }\end{array}$ & $19 / 05 / 12$ & $\mathrm{~N}$ & $28 / 05 / 12$ & $\mathrm{~N}$ & $11 / 06 / 12$ & $\mathrm{~N}$ & $09 / 08 / 12$ & $\mathrm{~N}$ & $03 / 12 / 12$ & NYCNYC01 & $31 / 07 / 13$ & $\mathrm{~N}$ & $11 / 11 / 14$ & $\mathrm{~N}$ & $26 / 03 / 15$ & $\mathrm{~N}$ \\
\hline $\begin{array}{c}\text { R. vitellinus, M, } \\
\text { EXTRA, PE, } \\
>10 \text { ANOS, VIVO }\end{array}$ & $31 / 05 / 12$ & RAMVIT01 & $01 / 05 / 14$ & $\mathrm{~N}$ & $10 / 07 / 14$ & RAMVIT01 & $30 / 10 / 14$ & $\mathrm{~N}$ & $05 / 03 / 15$ & $\mathrm{~N}$ & NR & NR & NR & NR & NR & NR \\
\hline $\begin{array}{c}\text { A. cygnoides, } \\
\text { LAGO 70, FPZSP, } \\
>10 \text { ANOS, MORTO }\end{array}$ & $16 / 12 / 12$ & NYCNYC01 & $16 / 09 / 13$ & PADOM09 & $01 / 11 / 14$ & NYCNYC01 & $17 / 12 / 14$ & NYCNYC01 & NR & NR & NR & NR & NR & NR & NR & NR \\
\hline $\begin{array}{l}\text { M. tomentosum, F, } \\
\text { EXTRA, SP, } \\
>10 \text { ANOS, VIVO }\end{array}$ & $17 / 05 / 13$ & $\mathrm{~N}$ & $07 / 06 / 13$ & $\mathrm{~N}$ & $13 / 06 / 13$ & $\mathrm{~N}$ & $12 / 07 / 13$ & $\mathrm{~N}$ & $22 / 08 / 13$ & MITOM01 & $27 / 05 / 15$ & $\mathrm{~N}$ & NR & NR & NR & NR \\
\hline $\begin{array}{l}\text { T. ferruginea, F, } \\
\text { EXP 77, FPZSP, } \\
>10 \text { ANOS, DESAP }\end{array}$ & $06 / 09 / 13$ & NYCNYC01 & 07/09/13 & NYCNYC01 & $10 / 09 / 13$ & NYCNYC01 & $24 / 09 / 13$ & $\mathrm{~N}$ & $26 / 09 / 13$ & $\mathrm{~N}$ & $21 / 10 / 13$ & $\mathrm{~N}$ & $31 / 10 / 13$ & $\mathrm{~N}$ & NR & NR \\
\hline $\begin{array}{c}\text { C. atratus, } \\
\text { LAGO 70, FPZSP } \\
\text { 5-10 ANOS, MORTO }\end{array}$ & $11 / 02 / 14$ & NYCNYC01 & $12 / 02 / 14$ & NYCNYC01 & $17 / 02 / 14$ & NYCNYC01 & $26 / 02 / 14$ & NYCNYC01 & $10 / 03 / 14$ & NYCNYC01 & NR & NR & NR & NR & NR & NR \\
\hline $\begin{array}{c}\text { A. aegyptiaca, SETOR, } \\
\text { FPZSP, } \\
>10 \text { ANOS, MORTO }\end{array}$ & $29 / 07 / 14$ & $\mathrm{~N}$ & $31 / 07 / 14$ & NYCNYC01 & $12 / 08 / 14$ & $\mathrm{~N}$ & $12 / 09 / 14$ & $\mathrm{~N}$ & $30 / 09 / 14$ & $\mathrm{~N}$ & NR & NR & NR & NR & NR & NR \\
\hline
\end{tabular}

F, fêmea; M, macho; Origem: FPZSP, Fundação Parque Zoológico de São Paulo; SP, São Paulo; RO, Rondônia; PE, Pernambuco; NR, não realizado. Recintos: Extra, Setor, Lago 70, Exposição 77 e Exposição 113. 


\subsection{Levantamento de Culicidae}

Devido a grande área compreendida pela FPZSP $\left(824.529 \mathrm{~m}^{2}\right)$, a escolha dos locais para realização das capturas entomológicas foi feita considerando-se os prováveis locais de transmissão dos hemosporídeos. Para determinação dos LPI dos animais, foi realizado um levantamento das suas mudanças de recinto ao longo de sua vida na FPZSP. A média de vezes em que os animais foram transferidos foi 5,4 vezes, e esse número variou entre 1 e 32 vezes, sendo que a maioria dos animais ficaram alojados em 2 recintos diferentes. Foi considerado como LPI o recinto em que o animal esteve nos 30 dias que antecederam a detecção da infecção. Doze pontos de LPI foram demarcados na área da FPZSP, sendo registrada a quantidade de indivíduos que possivelmente se infectou em cada ponto (Figura 23).

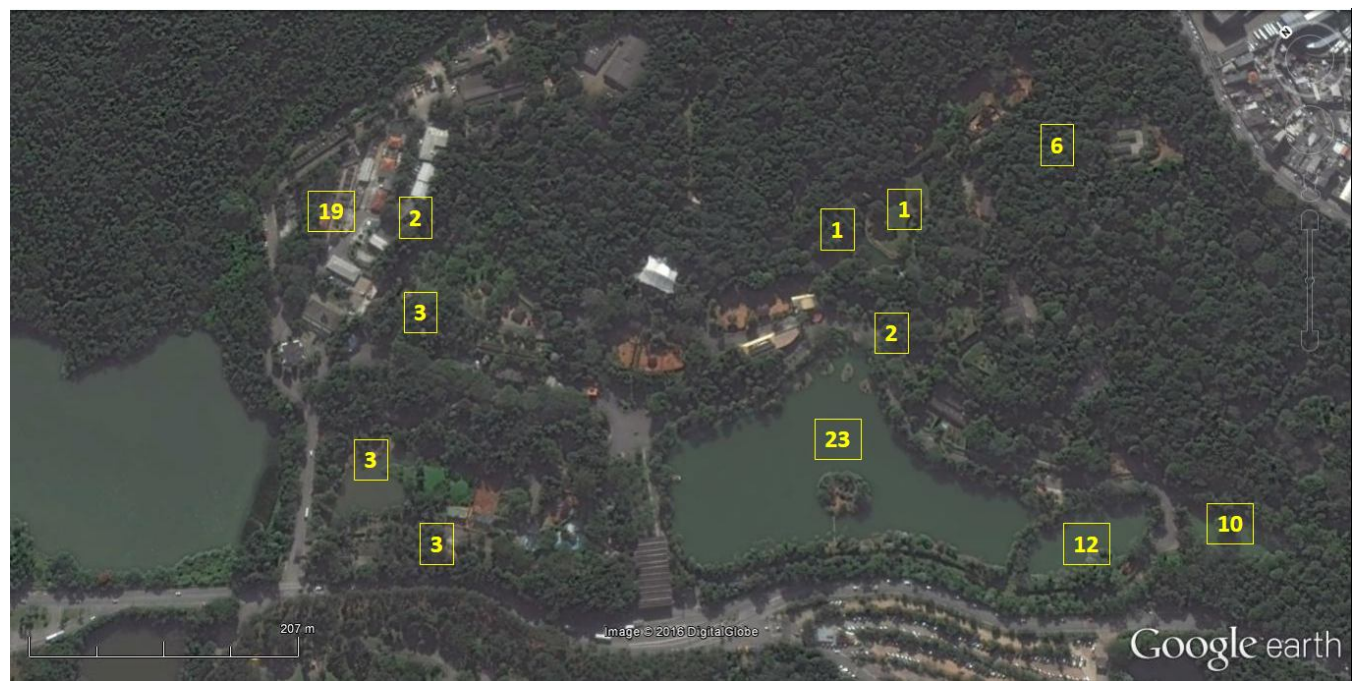

Figura 23 - Demonstração dos pontos de LPI na área da FPZSP. Os números representam a quantidade de indivíduos que possivelmente se infectou em cada ponto.

Assim, a partir da identificação dos LPIs, foram escolhidos 8 pontos para a colocação de armadilhas Mini CDC UV e 4 pontos para a realização da aspiração. Um total de 2042 indivíduos da Família Culicidae foram coletados, dentre os quais 
59 por meio da técnica de aspiração e 1983 atraídos pelas armadilhas CDC(s) iscadas com gelo seco. Com relação às fêmeas ingurgitadas, foram coletadas 31 no total: 16 em armadilhas $\mathrm{CDC}(\mathrm{s})$ e 15 com a técnica de aspiração. Apesar de terem sido encontradas em todos os pontos de coleta, a maioria dos indivíduos ingurgitados foi coletada no Bosque das Aves (10 indivíduos). Somente uma fêmea grávida foi registrada.

Dentre os sete gêneros registrados para a família Culicidae observa-se que o maior percentual de exemplares foi registrado para Culex $(75,8 \%)$ seguido pelo gênero Aedes (15\%). Os demais gêneros apresentaram um percentual menor de exemplares: Mansonia (5,6\%), Anopheles (3,1\%), Coquillettidia (0,2\%), Uranotaenia $(0,2 \%)$ e Limatus $(<0,1 \%)$ (Gráfico 9).

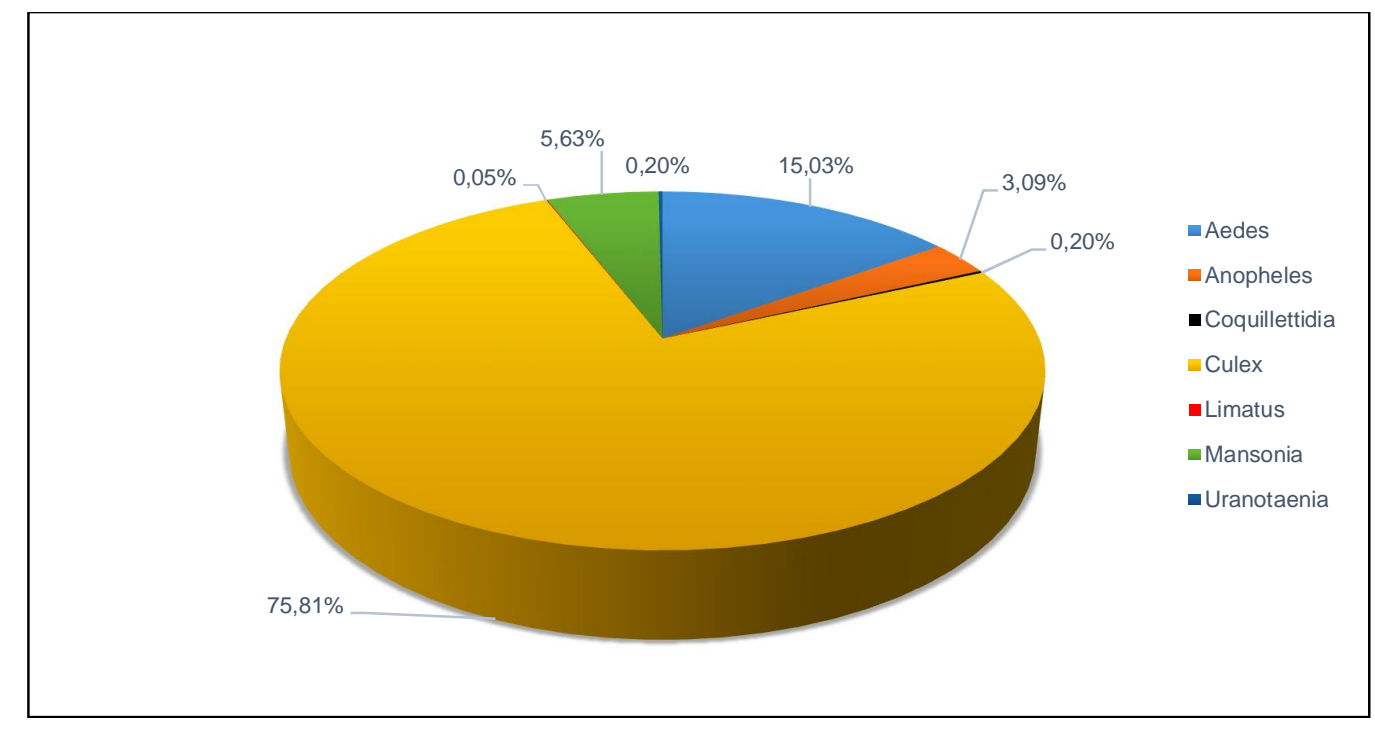

Gráfico 9 - Ocorrência dos gêneros de mosquitos da família Culicidae coletados na FPZSP.

O gênero com maior riqueza de espécies foi Culex. Dentre as espécies ou grupo de espécies identificadas para o subgênero Culex $=(C u x$. $)$ destaca-se 536 exemplares fêmeas de Culex (Cux.) spp., ou seja, identificados até a categoria de subgênero, seguido por 228 Culex (Cux.) Complexo Coronator, 209 Culex (Cux.) bidens, 139 Culex (Cux.) declarator, 67 Culex (Cux.) habilitator, 65 Culex ameliae 
aff, 37 Culex (Cux.) chidesteri, 28 Culex (Cux.) scimitar, 10 Culex (Cux.) nigripalpus aff, 5 Culex (Cux.) dolosus, 2 Culex (Cux.) saltanensis e 1 Culex (Cux.) quinquefasciatus. No subgênero Microculex = (Mcx.), foram registrados 5 exemplares de Culex (Mcx.) imitator imitator. No subgênero Melanoconion $=(M e l$.$) ,$ foram registrados 218 exemplares (Tabela 4).

Para o gênero Aedes do subgênero Ochlerotatus $=($ Och. $)$ foram registrados 292 exemplares de Aedes (Och.) scapularis, frequentemente encontrados em todos os pontos de coleta. Para o subgênero Stegomyia $=($ Stg. $)$ registrou-se 15 exemplares de Aedes (Stg.) albopictus, que apenas não ocorreu no Recinto dos Flamingos e na Ponte (Tabela 4).

$\mathrm{O}$ gênero Mansonia $=($ Man. $)$ de subgênero de mesmo nome apresentou 65 exemplares de Mansonia (Man.) indubitans, sem ocorrência apenas no Recinto 69, 25 Mansonia (Man.) titillans, com registro de ocorrência em todos os recintos, 18 Mansonia (Man.) pseudotitillans, sem ocorrência apenas no Recinto 113 e 7 Mansonia (Man.) sp., registradas apenas no Bosque das Aves, Lago 70 e Recinto dos Flamingos (Tabela 4).

No caso do gênero Anopheles, foram registradas somente espécies ou grupo de espécies pertencentes ao subgênero Nyssorhynchus $=($ Nys. $)$ da Seção Albimanus: 33 exemplares de Anopheles (Nys.) evansae, não sendo registrado no Recinto 61, 21 Anopheles (Nys.) strodei, ausentes no Extra, 5 Anopheles (Nys.) sp., registrados em metade dos pontos de coleta (Bosque das Aves, Recinto 113, Recinto 69 e Ponte), 3 Anopheles (Nys.) galvaoi, coletados no Lago 70, Recinto dos Flamingos e Recinto 61 e 1 Anopheles (Nys.) strodei, coletado no Recinto dos Flamingos (Tabela 4).

Em menor quantidade, as armadilhas $\mathrm{CDC}(\mathrm{s})$ iscadas com $\mathrm{CO}_{2}$ coletaram para a tribo Mansoniini: 2 Coquillettidia (Rhy.) hermanoi, 1 Coquillettidia (Rhy.) nigricans e 1 Coquillettidia (Rhy.) sp., todas do subgênero Rynchotaenia $=($ Rhy. $)$, e registradas apenas no Recinto 38. Quatro exemplares da tribo Uranoteniini Uranotaenia (Ura.) pulcherrima foram registrados para o Recinto dos Flamingos. Para a tribo Sabethini registrou-se apenas um exemplar de Limatus durhamii no Recinto 61 (Tabela 4). 
Tabela 4 - Composição das espécies de mosquitos Culicidae coletados com armadilhas $\mathrm{CDC}(\mathrm{s})$ iscadas com $\mathrm{CO}_{2}$ e aspiração durante o período de estudo em recintos do Parque Zoológico de São Paulo.

\begin{tabular}{|c|c|c|c|c|c|c|c|c|c|}
\hline & BA & L70 & R113 & FM & R61 & R69 & EX & PO & Total \\
\hline Culex (Cux.) sp. & 33 & 46 & 14 & 53 & 84 & 126 & 6 & 172 & 534 \\
\hline Aedes (Och.) scapularis & 50 & 57 & 48 & 19 & 14 & 38 & 38 & 28 & 292 \\
\hline Culex (Cux.) Complexo Coronator & 44 & 22 & 1 & 9 & 44 & 85 & - & 23 & 228 \\
\hline Culex (Mel.) Seção Melanoconion & - & 66 & - & 2 & 25 & 31 & 2 & 92 & 218 \\
\hline Culex (Cux.) bidens & 7 & 2 & 15 & 44 & 20 & 23 & - & 98 & 209 \\
\hline Culex (Cux.) declarator & 19 & 13 & 23 & 5 & 22 & 29 & 7 & 21 & 139 \\
\hline Culex (Cux.) habilitator & 10 & 13 & 18 & 10 & 16 & - & - & - & 67 \\
\hline Culex (Cux.) ameliae aff & 6 & 13 & 2 & 13 & 12 & 5 & 1 & 13 & 65 \\
\hline Mansonia (Man.) indubitans & 9 & 9 & 6 & 31 & 4 & - & 2 & 4 & 65 \\
\hline Culex (Cux.) chidesteri & 4 & 8 & 7 & 5 & - & - & - & 13 & 37 \\
\hline Anopheles (Nys.) evansae & 3 & 3 & 1 & 6 & - & 13 & 2 & 5 & 33 \\
\hline Culex (Cux.) scimitar & - & 1 & 4 & 3 & 4 & 16 & - & - & 28 \\
\hline Mansonia (Man.) titillans & 4 & 11 & 3 & 3 & 1 & 1 & 1 & 1 & 25 \\
\hline Anopheles (Nys.) strodei & 1 & 2 & 1 & 11 & 1 & 2 & - & 4 & 22 \\
\hline Mansonia (Man.) pseudotitillans & 1 & 4 & - & 7 & 2 & 1 & 1 & 2 & 18 \\
\hline Aedes (Stg.) albopictus & 1 & 3 & 2 & - & 1 & 4 & 4 & - & 15 \\
\hline Culex (Cux.) nigripalpus aff & - & 3 & - & - & - & 2 & - & 5 & 10 \\
\hline Mansonia (Man.) sp. & 1 & 2 & - & 4 & - & - & - & - & 7 \\
\hline Anopheles (Nys.) sp. & 1 & - & 1 & - & - & 1 & - & 2 & 5 \\
\hline Culex (Cux.) dolosus & - & - & - & - & 2 & 1 & 2 & - & 5 \\
\hline Culex (Mcx.) imitator imitator & 2 & - & - & 3 & - & - & - & - & 5 \\
\hline Uranotaenia (Ura). pulcherrima & - & - & - & 4 & - & - & - & - & 4 \\
\hline Anopheles (Nys.) galvaoi & - & 1 & - & 1 & 1 & - & - & - & 3 \\
\hline Coquillettidia (Rhy.) hermanoi & - & - & - & 2 & - & - & - & - & 2 \\
\hline Culex (Cux.) saltanensis & - & 1 & - & 1 & - & - & - & - & 2 \\
\hline Coquillettidia (Rhy.) nigricans & - & - & - & 1 & - & - & - & - & 1 \\
\hline Coquillettidia (Rhy.) sp. & - & - & - & 1 & - & - & - & - & 1 \\
\hline Culex (Cux.) quinquefasciatus & - & 1 & - & - & - & - & - & - & 1 \\
\hline Limatus durhamii & - & - & - & - & 1 & - & - & - & 1 \\
\hline
\end{tabular}

BA, Bosque das Aves; L70, Lago 70; R113, Recinto 113; R38, Recinto 38; R61, Recinto 61; R69, Recinto 69; EX, Extra; PO, Ponte. Para localização na área da FPZSP vide Figura 7.

A maioria dos indivíduos foi coletada na Ponte (23,7\%), seguida pelo Recinto $69(18,5 \%)$ e Lago $70(13,8 \%)$. O recinto com menor quantidade de mosquitos registrados foi o Extra, com 3,2\% do total (Gráfico 10). O local de coleta com o maior número de gêneros de Culicidae foi o Recinto dos Flamingos, com 6 diferentes gêneros, seguido pelo Recinto 61 com 5 gêneros. Os demais locais de coleta 
apresentaram todos os 4 gêneros mais abudantes, Culex, Aedes, Mansonia e Anopheles (Gráfico 11). Anopheles sp. esteve presente em maior proporção no Recinto dos Flamingos, enquanto que Culex sp. esteve mais presente no Recinto $61 \mathrm{e}$ na Ponte e Mansonia no Recinto dos Flamingos.

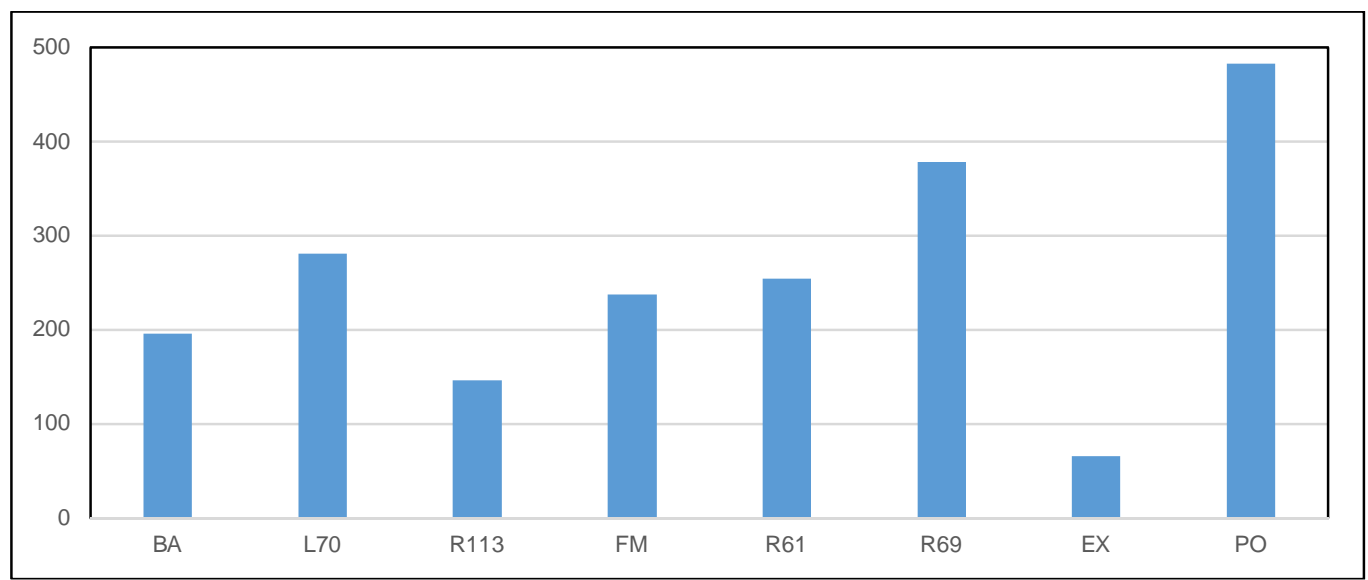

Gráfico 10 - Distribuição dos mosquitos Culicidae coletados na FPZSP por ponto de coleta.

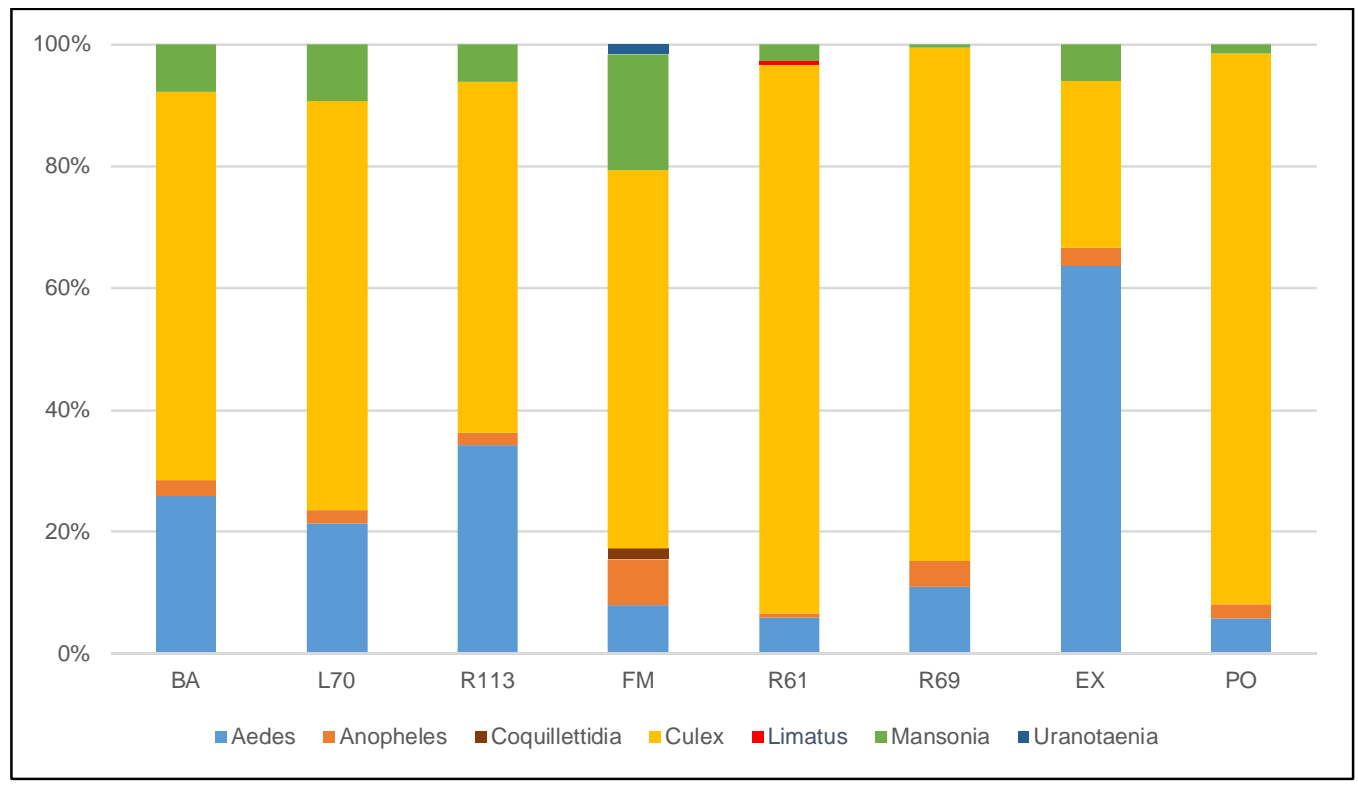

Gráfico 11 - Riqueza de gêneros de Culicidae encontrada na FPZSP segundo ponto de coleta. 


\subsection{Fontes de repasto sanguíneo}

Para a avaliação da fonte de repasto sanguíneo de Culicidae, foram analisados 31 mosquitos que se apresentavam ingurgitados ou com traços de sangue no abdome. A grande maioria dos indivíduos ingurgitados pertence ao gênero Culex $(87,1 \%)$. Os demais estão distribuídos igualmente entre os gêneros Aedes, Anopheles, Mansonia e Uranotaenia (3,2\% cada). Dentre os 31 indivíduos ingurgitados, não foi possível a amplificação de nenhum DNA de vertebrado em 6 indivíduos (19,4\%). A espécie com maior quantidade de indivíduos ingurgitados foi Culex (Cux.) declarator, representando $31,3 \%$ dos indivíduos.

A fonte de repasto sanguíneo mais frequentemente encontrada foi Homo sapiens, estando presente em 10 mosquitos, seguida por Nycticorax nycticorax, presente em 3 mosquitos. Também foram identificadas como fonte de repasto sanguíneo: Pipile jacutinga (jacutinga), Spizaetus ornatos (gavião-de-penacho), Cygnus atratus (cisne-preto), Pavo muticus (pavão-verde), Didelphis aurita (gambáde-orelha-branca), Ardea herodias (garça-grande-branca), Anser anser (marreco-debico-laranja), Turdus rifiventris (sabiá-laranjeira), Canis lupus familiaris (cão doméstico), Cathartes melambrotus (urubu-da-mata) (Tabela 5). 
Tabela 5 - Fontes de repasto sanguíneo identificadas nos mosquitos ingurgitados.

\begin{tabular}{|c|c|c|c|c|}
\hline $\begin{array}{l}\text { Mosquito } \\
\text { no. }\end{array}$ & Espécie & Armadilha & Recinto & $\begin{array}{l}\text { Fonte de Repasto } \\
\text { Identificada }\end{array}$ \\
\hline 1 & Culex (Cux.) declarator & ASP & BA & $\begin{array}{l}\text { 99\% Pipile jacutinga } \\
\text { 99\% Homo sapiens }\end{array}$ \\
\hline 2 & Culex (Cux.) declarator & ASP & $\mathrm{BA}$ & Não identificada \\
\hline 3 & Culex (Cux.) declarator & ASP & BA & $100 \%$ Homo sapiens \\
\hline 4 & Culex (Cux.) declarator & ASP & BA & 99\% Spizaetus ornatos \\
\hline 5 & Culex (Cux.) declarator & ASP & BA & $\begin{array}{c}98 \% \text { Nycticorax } \\
\text { nycticorax }\end{array}$ \\
\hline 6 & Culex (Cux.) chidesteri & ASP & BA & $100 \%$ Homo sapiens \\
\hline 61 & Aedes (Och.) scapularis & $\mathrm{CDC}$ & BA & $100 \%$ Homo sapiens \\
\hline 120 & Mansonia (Man.) titillans & $\mathrm{CDC}$ & EX & 99\% Homo sapiens \\
\hline 333 & Culex (Cux.) declarator & ASP & $\mathrm{PO}$ & Não identificada \\
\hline 337 & Culex (Cux.) declarator & ASP & FM & $\begin{array}{c}\text { 99\% Homo sapiens } \\
\text { 99\% Cathartes } \\
\text { melambrotus }\end{array}$ \\
\hline 338 & Culex (Cux.) declarator & ASP & FM & $\begin{array}{l}\text { 99\% Canis lupus } \\
\text { familiaris }\end{array}$ \\
\hline 339 & Culex (Cux.) chidesteri & ASP & FM & Não identificada \\
\hline 342 & Culex (Cux.) declarator & ASP & FM & Não identificada \\
\hline 345 & Culex (Cux.) sp. & ASP & L70 & 99\% Homo sapiens \\
\hline 431 & Culex (Cux.) ameliae & $\mathrm{CDC}$ & R69 & 99\% Cygnus atratus \\
\hline 533 & Culex (Cux.) Complexo Coronator & $\mathrm{CDC}$ & $\mathrm{BA}$ & $\begin{array}{l}\text { 97\% Cygnus atratus } \\
99 \% \text { Homo sapiens }\end{array}$ \\
\hline 635 & Anopheles (Nys.) evansae & $\mathrm{CDC}$ & R69 & 99\% Homo sapiens \\
\hline 770 & Cx. (Mel.) Seção Melanoconion & $\mathrm{CDC}$ & L70 & Não identificada \\
\hline 877 & Uranotaenia (Ura). pulcherrima & ASP & FM & $100 \%$ Homo sapiens \\
\hline 882 & Culex (Cux.) Complexo Coronator & ASP & BA & 99\% Pavo muticus \\
\hline 885 & Culex (Cux.) declarator & ASP & $\mathrm{BA}$ & 100\% Didelphis aurita \\
\hline 965 & Culex (Cux.) sp. & $\mathrm{CDC}$ & R69 & 100\% Homo sapiens \\
\hline 1008 & Culex (Cux.) scimitar & $\mathrm{CDC}$ & R113 & 99\% Homo sapiens \\
\hline 1110 & Culex (Cux.) habilitator & $\mathrm{CDC}$ & L70 & 99\% Anser anser \\
\hline 1226 & Culex (Cux.) Complexo Coronator & $\mathrm{CDC}$ & R69 & $\begin{array}{c}99 \% \text { Turdus } \\
\text { rufiventris }\end{array}$ \\
\hline 1256 & Culex (Cux.) sp. & $\mathrm{CDC}$ & $\mathrm{PO}$ & $99 \%$ Cygnus atratus \\
\hline 1371 & Culex (Cux.) sp. & $\mathrm{CDC}$ & $\mathrm{PO}$ & $\begin{array}{c}98 \% \text { Nycticorax } \\
\text { nycticorax }\end{array}$ \\
\hline 1394 & Culex (Cux.) sp. & $\mathrm{CDC}$ & R69 & Não identificada \\
\hline 1823 & Culex (Cux.) Complexo Coronator & $\mathrm{CDC}$ & R61 & 99\% Homo sapiens \\
\hline 2073 & Cx. (Mel.) Seção Melanoconion & $\mathrm{CDC}$ & L70 & 99\% Ardea herodias \\
\hline 2078 & Cx. (Mel.) Seção Melanoconion & $\mathrm{CDC}$ & L70 & $\begin{array}{c}99 \% \text { Nycticorax } \\
\text { nycticorax }\end{array}$ \\
\hline
\end{tabular}


Em três mosquitos foram encontradas sequências para pelo menos duas fontes de repasto: humana e ave (Pipile jacutinga, Cathartes melambrotus e Cygnus atratus).

O ser humano foi identificado como fonte de repasto sanguíneo em praticamente todos os recintos, com exceção da ponte. Mosquitos ingurgitados com sangue de aves foram encontrados em 5 recintos diferentes, com exceção dos Recinto 113, Recinto 61 e Extra. Sangue de mamíferos, que não seres humanos, foram encontrados somente no Bosque das Aves e no Recinto dos Flamingos (Gráfico 12).

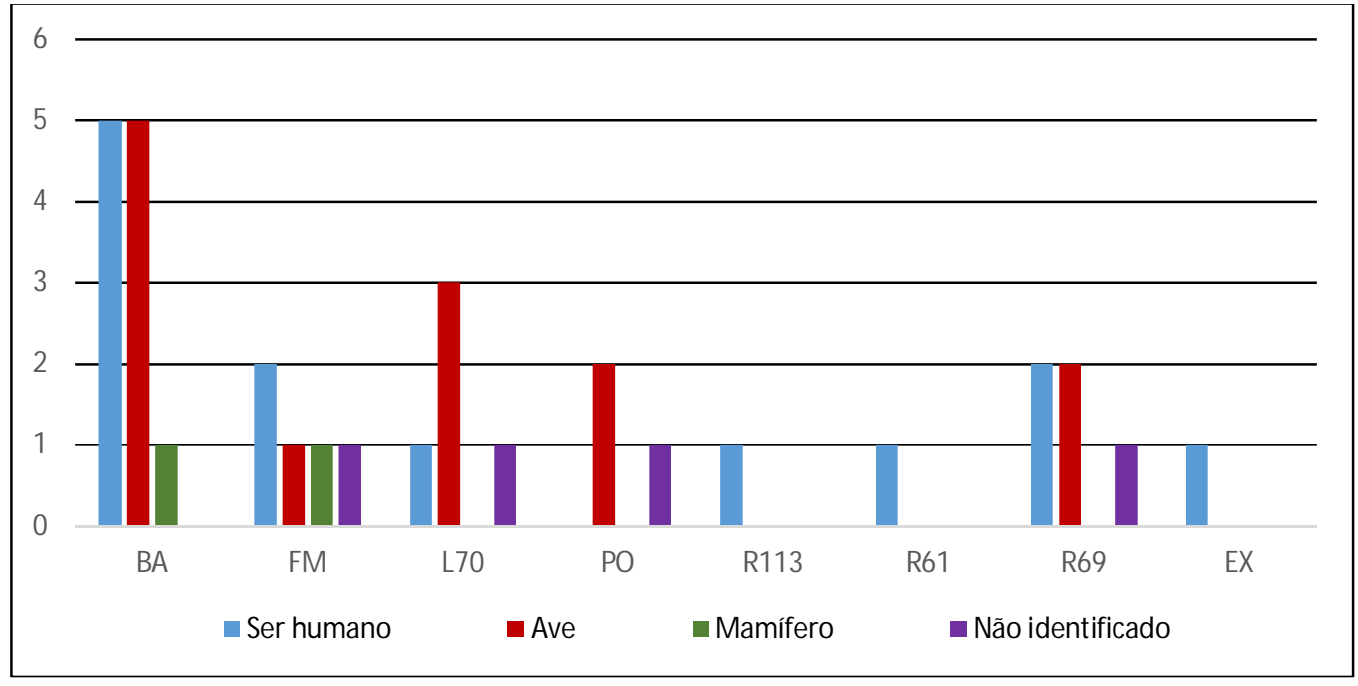

Gráfico 12 - Diversidade de fontes de repasto sanguíneo por recinto amostrado. 


\section{DISCUSSÃO}

A malária aviária é uma ameaça crescente a muitas espécies de aves ao redor do mundo. As aves cativas podem ser particularmente suscetíveis a infecções e os zoológicos, que atualmente possuem um importante papel na conservação das espécies, têm relatado mortes em diferentes espécies e em diversas partes do planeta. Apesar do conhecimento que se tem de que a suscetibilidade das aves frente a esses parasitas pode variar entre espécies, Famílias e até mesmo Ordens, não há estudos tão amplos como esse sendo realizados em zoológicos ao redor do mundo.

Este foi o primeiro estudo realizado em um zoológico brasileiro que pesquisou hemosporídeos em diferentes Ordens, sendo capaz de amostrar uma grande diversidade de aves e quase a totalidade de espécies mantidas pela FPZSP. A dinâmica de envio/recebimento de animais bem como de nascimentos/óbitos é grande e o acompanhamento de todos os indivíduos representa um desafio. Apesar disso, esse estudo conseguiu abranger uma grande variedade de indivíduos. Somado a este fato, também foi possível amostrar uma grande variedade de espécies de animais que ocorrem no Brasil. Poucos estudos conseguem abranger tantas espécies, pois em geral os trabalhos se concentram em espécies de Passeriformes e em locais de clima temperado ${ }^{52}$.

A maioria das espécies de aves é de difícil captura, devido à altura de vôo, locais de nidificação, hábitos alimentares e migratórios. Entretanto, alguns grupos como é o caso dos Passeriformes, podem ser facilmente amostrados através de métodos relativamente simples, como captura por rede de neblina. Por esta metodologia, o animal é capturado em pleno vôo e, portanto, tem maior possibilidade de estar livre de enfermidades, já que animais doentes tendem a ficar prostrados e apáticos. Esse fato influencia os dados obtidos, evidenciando uma maior positividade de animais com doença em fase crônica, e levou pesquisadores a acreditarem por algum tempo que esses parasitas eram pouco patogênicos para os seus hospedeiros ${ }^{52}$.

Estudos realizados no Brasil já mostraram uma positividade semelhante à encontrada neste trabalho (12,6\% entre os animais cativos da FPZSP). Em um estudo envolvendo pinguins de centros de reabilitação, a prevalência encontrada variou 
entre $6,6 \%$ e $13,5 \%{ }^{44}$. Entretanto, quando comparamos com a positividade obtida em psitacídeos cativos em três zoológicos brasileiros (36\%), a positividade do nosso estudo foi bem menor ${ }^{75}$. Um dado interessante é que a positividade encontrada entre os animais cativos foi semelhante aos $18 \%$ encontrados entre aves de vida livre, amostradas no mesmo local (APÊNDICE C) ${ }^{49}$. Também é semelhante àquela encontrada em outros trabalhos realizados na América do Sul $1^{30,46,120}$ e Central ${ }^{121}$.

Não foi encontrada associação significativa da positividade com a idade ou sexo dos animais. Outros estudos mostram que os parasitas da malária aviária podem ser igualmente prevalentes entre adultos e jovens, apesar de afirmar que machos são mais propensos a se infectarem, independentemente da idade ${ }^{122}$.

Houve um predomínio de infecções por Plasmodium entre os animais positivos quando comparado com Haemoproteus (83 animais positivos para Plasmodium e apenas dois para Haemoproteus), indicando um envolvimento ativo de mosquitos na transmissão de hemosporídeos no local do estudo. As espécies de Haemoproteus não são transmitidas por mosquitos e sim por insetos Culicoides da Família Ceratopogoniade e moscas da Família Hippoboscidae ${ }^{10}$. A distribuição desses vetores na área do zoo ainda não foi investigada. Além disso, Haemoproteus parecem ser mais específicos para algumas espécies de hospedeiros ${ }^{10}$, o que pode restringir sua transmissão entre as aves do zoo, que pertencem a espécies tão distantes taxonomicamente.

Após consulta no banco de dados do MalAvi, foi possível verificar que duas espécies de aves já possuíam linhagens de Haemosporida ligadas a elas: Psarocolius decumanus e Tadorna ferruginea; e no GenBank foram encontradas sequências de Plasmodium e Haemoproteus ligadas a Phoenicopterus chilensis, Pipile jacutinga e Saltator atricolis. Todas as demais espécies de aves encontradas positivas neste estudo representam a primeira descrição de infecção por esses parasitas.

Com relação às duas linhagens de Haemoproteus encontradas, foi possível determinar a espécie de PENOBS01, linhagem encontrada infectando Penelope obscura (Galliformes: Cracidae). Existem nove espécies de Haemoproteus encontradas em Galliformes, com somente duas delas descritas em Cracidae $(H$. cracidarum e $H$. ortalidum $)^{10}$. H. cracidarum possui como característica principal a presença de aproximadamente 20 pigmentos de hemozoína e gametócitos maduros 
com acentuada forma ameboide, deslocando o núcleo do eritrócitos infectado, podendo ainda envolver completamente o núcleo, e nos parasitas encontrados no esfregaço sanguíneo essas características não estão presentes. Entretanto, em $H$. ortalidum os gametócitos maduros podem ser tanto alongados quanto circulares e há presença de vacúolos nos macrogametócitos alongados que são bem característicos desta espécie. Na nossa amostra somente gametócitos alongados foram encontrados, talvez devido à baixa parasitemia, mas os vacúlos puderam ser visualizados, confirmando se tratar de $H$. ortalidum. Até o momento não havia nenhuma sequência correspondente à $H$. ortalidum depositada nos bancos de dados, e, portanto, este estudo possibilitou o estabelecimento do código de barras de DNA para esse parasita.

A outra linhagem de Haemoproteus descoberta foi EUDRUB01, encontrada em Eudocimus ruber (Pelecaniformes: Threskiornithidae), onde poucas espécies de hemosporídeos foram descritas. Através da análise morfológica do parasita, é possível afirmar que não se trata de $H$. pelouroi, uma vez que este possui gametócitos com acentuada forma ameboide ${ }^{10}$. Também não é possível afirmar que se trata de $H$. crumerium, já que este possui um núcleo que fica mais próximo ao núcleo do eritrócito $^{10}$, e encontramos macrogametócitos com núcleo na periferia celular. EUDRUB01 apresentou 99\% de similaridade com duas sequências: HALMAL01 encontrada em Halcyon malimbica (Coraciiformes: Alcedinidae), mas sem espécie identificada ${ }^{123}$, e FREAND01 de H. valkiunasi. Outras espécies descritas apresentam identidade de 98\% com EUDRUB01: CIRCUM01 (H. noctuae), PICAN02 (H. homovelans) e ALCLEU01 (H. enucleator). Todas essas linhagens apresentam diferenças morfológicas marcantes, capazes de excluir a possibilidade de correspondência de EUDRUB01 com qualquer uma delas e foram descritas em hospedeiros de Ordens diferentes. H. valkiunasi possui macrogametócitos com pequenos vacúolos, hemozoína ocasionalmente agregada nos polos, mas em geral distribuída pelo citoplasma do parasita ${ }^{124}$. H. noctuae, descrito em Strigiformes, possui gametócitos que crescem ao redor do núcleo do eritrócito infectado, podendo deslocar o núcleo lateralmente ${ }^{10}$. H. enucleator, descrito em Coraciiformes, na Etiópia, tem gametócitos maduros que provocam a completa enucleação dos eritrócitos infectados, além de formato mais alongado e bem robusto ${ }^{10}$. $H$. homovelans foi descrito em Piciformes e apresenta macrogametócitos que não 
encostam no núcleo, e vão assumindo uma forma discretamente amebóide conforme vão ficando maduros ${ }^{24}$. $\mathrm{Na}$ análise filogenética todas essas linhagens ficaram agrupadas no mesmo clado, com uma boa probabilidade posterior. Apesar de a amostra apresentar baixa parasitemia, insuficiente para identificação morfológica da espécie do parasita, há a uma boa possibilidade de estarmos lidando com uma espécie totalmente nova.

NYCNYC01 foi a linhagem com maior prevalência, encontrada em $40 \%$ dos indivíduos positivos, em um total de 16 espécies diferentes, provando ser uma linhagem generalista. Esta linhagem foi previamente descrita na área do FPZSP infectando aves de vida livre como Nycticorax nycticorax (Pelecaniformes: Ardeidae) e Penelope superciliaris (Galliformes: Cracidae) ${ }^{49}$. Devido à alta similaridade (99\%), esta é provavelmente uma variante de PESA01 que encontramos infectando quatro animais e que já foi descrita no Alasca ${ }^{21}$, Uruguai ${ }^{29} \mathrm{e}$ no Brasil ${ }^{41}$ em Charadriiformes, Columbiformes e Passeriformes, respectivamente. Apesar de frequente, esta linhagem apareceu somente em baixas parasitemias e/ou associada com Haemoproteus sp., tornando impossível a identificação morfológica da espécie de Plasmodium sp.

Importante destacar que este estudo encontrou também uma amostra positiva com a linhagem NYCNYC01 em avestruz (Struthio camelus). Há um relato de Plasmodium struthionis em avestruzes do Sudão ${ }^{125}$, mas trata-se de um caso de incertae sedis (posição incerta), indicando a incapacidade de estabelecer a posição exata deste táxon dentro da classificação ${ }^{10}$. No entanto, este resultado pode ser devido ao possível desenvolvimento abortivo de algumas infecções quando elas aparecem em hospedeiros não adaptados, visto que a presença de estágios sanguíneos e gametócitos na circulação do avestruz não foram confirmadas pela microscopia ${ }^{79}$.

A alta proporção de infecção por NYCNYC01 entre os animais positivos e com baixas parasitemias pode indicar que esta linhagem está bem adaptada a estas espécies e circula pela região do zoológico há algum tempo. Parasitas que são generalistas com relação aos seus hospedeiros possuem uma maior habilidade de dispersão ${ }^{126-127}$. Neste caso também pode estar ocorrendo o "efeito de amplificação" que é quando a alta diversidade de hospedeiros aumenta a quantidade de hospedeiros suscetíveis, aumentando as chances de encontros entre os hospedeiros e os vetores 
infectados, resultando em altas prevalências do parasita ${ }^{128}$. Também é esperado que parasitas generalistas ocupem uma maior área de distribuição geográfica devido a sua capacidade de explorar uma maior variedade de hospedeiros e ambientes, conforme demonstrado na hipótese a amplitude de nicho ${ }^{129}$. Parasitas aviários podem se beneficiar do fato de que as aves voam longas distâncias, colonizando locais distantes e até mesmo áreas remotas ${ }^{130-131}$ e, apesar de NYCNYC01 ter sido encontrado somente no continente Americano, PESA01 foi encontrado inclusive no Alasca.

A megadiversidade de hospedeiros encontradas no Zoológico de São Paulo, composta por espécies nativas da Mata Atlântica, espécies cativas deste e de outros biomas brasileiros, bem como a presença de animais exóticos, provavelmente beneficiou espécies de parasitas generalistas, como é o caso de NYCNYC01. Esta linhagem está entre as três mais generalistas já descritas. Foi encontrada em 7 Ordens, enquanto que a linhagem SGS1 de P. relictum foi encontrada em 11 Ordens e de Plasmodium sp. BUL07, também foi descrita em 7 Ordens. NYCNYC01 é até mesmo mais generalista que a linhagem GRW04 de $P$. relictum, encontrada em três Ordens. A maioria das outras linhagens que foram reportadas infectando diversas Ordens possui espécie de Plasmodium já descrita, como é o caso de TURDUS01, SEIAUR01 e SW5 ( $P$. circumflexum, $P$. cathemerium e $P$. circumflexum, respectivamente) reforçando a necessidade de dar continuidade a este trabalho e somar esforços para a identificação morfológica e descrição da espécie de NYCNYC01 e de PESA01.

Vale ressaltar que $P$. relictum é uma espécie com ampla distribuição, com diferentes linhagens descritas (GRW04, SGS1, LZFUS01 e GRW11), mas não foi detectada durante este estudo, embora já tenha sido encontrada no Brasil ${ }^{9}$. A linhagem GRW04 foi encontrada em Passer domesticus de Uberlândia/MG e Campo Grande/MS ${ }^{9}$. Há vários fatores que possam ter contribuído para a ausência de $P$. relictum no nosso estudo: (i) Passer domesticus (pardal) não foi investigado nesse estudo; (ii) Culex quinquefasciatus, seu principal vetor, embora comumente encontrado na cidade de São Paulo ${ }^{132}$ não foi abundantemente coletado; (iii) um possível isolamento geográfico deste parasita ou do local de estudo. 
DENPET03, P. nucleophilum, a segunda linhagem mais frequente deste estudo, foi encontrada infectando principalmente Anatidae $(69,2 \%$ das amostras), o que poderia sugerir uma certa predisposição dessa linhagem com esse grupo de hospedeiros. O barcoding descrito previamente para esta espécie ${ }^{48}$ foi essencial para a identificação deste parasita em 12 indivíduos, uma vez que estes não apresentavam nenhuma parasitemia. Esta sequência foi descrita anteriormente na América do Sul e do Norte em Anseriformes ${ }^{48}$, Charadriiformes ${ }^{133}$, Passeriformes ${ }^{9}$, 29, 41, 134-138 Psittaciformes $^{29}$ e Sphenisciformes ${ }^{44}$.

MYCAME02 foi encontrado neste estudo infectando hospedeiros de duas Ordens diferentes (Anseriformes e Phoenicopteriformes). Esta linhagem já foi descrita no Cerrado brasileiro infectando Mycteria americana (Ciconiiformes: Ciconiidae ${ }^{120}$ e no Alasca em Dendroica steophaga (Passeriformes: Parulidae) ${ }^{138}$. Neste estudo, esta linhagem apareceu primeiramente em setembro de 2014, após mais de três anos e meio do início do projeto, em exemplares de Phoenicopterus chilensis. O grupo de flamingos ao qual esse animal faz parte veio de outra instituição localizada no interior do Estado de São Paulo. Após 8 meses desse primeiro exame positivo, um exemplar de Cygnus atratus foi encontrado positivo para a mesma linhagem. MYCAME02 pode ser uma linhagem rara, mas está circulante e há a possibilidade de sua introdução no plantel da FPZSP através dos exemplares de $P$. chilensis. Todas as amostras que apresentaram essa linhagem foram negativas no esfregaço sanguíneo.

ARACAJ01 pertence a Plasmodium sp. e é uma das novas linhagens encontradas neste estudo. Foi descrita em Aramides cajaneus (Gruiformes: Rallidae) e possui $96 \%$ de identidade com LEPCOR04, descrito em Passeriformes da América do $\mathrm{Sul}^{139}$. A sequência mais próxima com espécie descrita é da linhagem TFUS06 de P. unalis (95\%), indicando a possibilidade, mais uma vez, de estarmos lidando com uma nova espécie de Plasmodium sp.

NOTURU01 foi encontrado em Nothocrax urumutum (Galliformes:Cracidae). Apesar de não termos esfregaços sanguíneos desta amostra, provavelmente este parasita pertence ao subgênero Haemamoeba, uma vez que ficou agrupado juntamente com outras espécies deste subgênero. Possui alta similaridade (98\%) com 
CINCHA01 que já foi encontrado em diferentes espécies de Passeriformes africanos ${ }^{140-141}$.

PADOM09, linhagem identificada como sendo $P$. elongatum $^{142}$ ficou agrupada com $P$. cathemerium e não com $P$. elongatum na análise filogenética. Há relatos de que essa linhagem possa estar identificada erroneamente nos bancos de $\operatorname{dados}^{9,} 41,123$, e a nossa análise filogenética corrobora com isso, uma vez que PADOM09 forma um clado com boa probabilidade posterior com P. cathemerium. Entretanto, a nossa amostra positiva para esta linhagem não possuía parasitemia suficiente para a identificação/confirmação morfológica da espécie. Outro fato interessante é que esta linhagem foi encontrada em um único indivíduo de Anser cygnoides durante todo o estudo, e a FPZSP possuía somente este indivíduo da espécie, que ficava alocado em um dos lagos, juntamente com uma grande quantidade de indivíduos da Família Anatidae. É importante, portanto, aprofundar os estudos e entender porque essa linhagem não foi encontrada em nenhum outro indivíduo de Anatidae, identificando o fator limitante da disseminação do parasita no vetor ou no hospedeiro vertebrado.

SPMAG06 é uma linhagem de Plasmodium encontrada em Musophaga violacea e apresenta 99\% de identidade com TFUS05, uma linhagem de P. lutzi descrita em Turdus fucaster da Colômbia ${ }^{32}$. Provavelmente SPMAG06 é uma variante de TFUS05, apesar de não ter sido possível a confirmação morfológica da espécie, devido à ausência de parasitemia detectável em esfregaço sanguíneo. Durante este estudo, SPMAG06 apareceu uma única vez, mas esta linhagem já foi anteriormente descrita no Zoológico de São Paulo ${ }^{47}$, com diferença de 7 anos entre as detecções. Sua baixa prevalência pode ser devido à ausência de hospedeiros específicos na região, apesar disso, ela pode ser prejudicial a algum animal que venha a ser incorporado ao plantel no futuro, especialmente pinguins.

SALAT01 é uma linhagem de Plasmodium encontrada em Saltator atricolis (Passeriformes: Thraupidae). O esfregaço sanguíneo mostra a presença de parasitas pertencentes a dois subgêneros de Plasmodium, mas apenas uma sequência, que na árvore filogenética agrupa com outras do subgênero Novyella, foi amplificada por PCR. Esta linhagem tem $97 \%$ de similaridade com TUMIG03, encontrada anteriormente em outros Passeriformes ${ }^{29,41,58,134,138,143-145}$ e em Sphenisciformes ${ }^{44}$. 
MITOM01 foi encontrada em Mitu tomentosum (Galliformes: Cracidae) e em Phoenicopterus chilensis (Phoenicopteriformes: Phoenicopteridae) e apresenta $98 \%$ de similaridade com VIOLI07, que foi descrito em Vireo olivaceus, uma espécie de Passeriformes migrante da Colômbia ${ }^{146}$. Mais uma vez foram obtidos somente esfregaços sanguíneos negativos, no caso de $P$. chilensis ou mesmo não ter esfregaço para análise, como ocorreu com $M$. tomentosum, impossibilitando a identificação da espécie.

Uma das novas linhagens descritas por este estudo foi RAMVIT01, que possui uma similaridade de $96 \%$ com TFUS06, descrita como Plasmodium (Novyella) unalis e encontrada somente em Turdus fuscater (Passeriformes: Turdidade) na Colômbia ${ }^{31,146}$. Pela baixa similaridade encontrada entre as linhagens, possivelmente RAMVIT01 se trata de outra espécie de Plasmodium sp. Morfologicamente o parasita encontrado apresenta características próximas de $P$. rouxi por apresentar merontes com 4 merozoítos e em formato de "gravataborboleta". Apesar disso, os gametócitos são diferentes, pela presença de núcleo proeminente, por assumirem uma posição polar na célula infectada e presença de glóbulos refráteis poucos evidentes nos gametócitos maduros. A semelhança genética entre a sequência de $P$. rouxi (PADOM16) e RAMVIT01 é de $94 \%$, indicando que RAMVIT01 pode ser uma nova espécie.

Apesar de algumas linhagens terem sido encontradas em poucas espécies e, aparentemente, serem mais especialistas, esse pode ser um efeito de amostragem, uma vez que algumas espécies foram raramente amostradas. Esses parasitas especialistas podem ser considerados generalistas se mais amostras forem colhidas de diferentes hospedeiros.

Estudos apontam não haver diferença entre a sensibilidade da microscopia e do PCR quando a primeira é bem executada, com lâminas de boa qualidade ${ }^{88}$. Apesar de termos utilizado os mesmos protocolos, nossos resultados não corroboram com esses achados.

O protocolo de análise molecular não foi capaz de detectar as infecções mistas, o que representa um grande desafio a ser superado por todos os profissionais da área. Até o momento, a identificação dessas infecções é realizada com sucesso através de microscopia e as infecções por Plasmodium e Haemoproteus são as mais 
difíceis de serem detectadas a nível molecular ${ }^{86}$. Alguns autores apontam que essa dificuldade é consequência de que a maioria dos protocolos existentes foi desenvolvida com fragmentos genéticos conservados de Plasmodium e, portanto, amplificariam preferencialmente o DNA desse parasita, mesmo que a quantidade de material genético de Haemoproteus seja significativamente maior na amostra estudada $^{151}$. A combinação entre microscopia e PCR é essencial para a identificação e solução desses casos, até mesmo contribuindo para a diferenciação entre os gêneros, subgêneros e espécies, quando for o caso.

PCR é capaz de detectar a presença do DNA do parasita na circulação, o que não significa que o parasita está em processo de infecção ativa. Em mosquitos, o parasita pode sobreviver por diversas semanas ${ }^{152}$. Nas aves ainda não se sabe ao certo quais os mecanismos de interação entre parasita e hospedeiro, nem mesmo até que ponto as infecções abortivas podem ir. Novos estudos com infecções experimentais são necessários para a melhor compreensão de como esse mecanismo funciona para as diferentes espécies de parasitas e hospedeiros.

Devido a grande diferença entre a quantidade de animais da Família Anatidae e os demais, nas análises estatísticas verificou-se que as infecções estão significativamente relacionadas à Família Anatidade. Esta relação se explica pelo fato de que esses animais vivem muito próximos aos corpos de água, local utilizado como criadouro dos mosquitos vetores de Haemosporida, criando ambiente propício para a reprodução e manutenção das populações desses vetores, que se reproduzem, copulam e se alimentam dos animais que vivem próximo aos criadouros. Além disso, os lagos são cercados por diferentes tipos de vegetação, o que também proporciona abrigo às fêmeas ingurgitadas.

A determinação do LPI foi difícil, uma vez que, principalmente para os animais mais velhos, nem sempre a sua transferência de recinto era acompanhada de registros confiáveis. Outro fato relevante é a impossibilidade, em praticamente todos os casos, de determinar em qual fase da infecção o animal estava. Com a análise desses dados foi possível verificar que muitos animais positivos circularam entre um grande número de recintos. Um exemplo é um indivíduo de Tadorna ferruginea, que durante os 14 anos em que viveu na FPZSP, trocou de recinto pelo menos 32 vezes. Esse animal é considerado uma exceção frente aos demais. A média de troca de 
recintos foi de 5 vezes, e isso mostra o papel que os animais positivos e em fase crônica da infecção podem desempenhar como reservatórios, podendo levar a infecção a outros locais do parque.

Para a confirmação de espécie do mosquito, muitas vezes é necessário análisar machos e fêmeas. Como quase a totalidade de mosquitos coletados durante este projeto foi de fêmeas, não foi possível confirmar muitas espécies, e a maioria delas foi identificada apenas até gênero. A maioria dos indivíduos de Culex encontrase nessa situação. Para solucionarmos essa questão seria necessária a realização de novas coletas na região de estudo ou a realização de testes moleculares.

Apesar das limitações existentes, foi possível identificar uma grande variedade de espécies de Culicidae (21 no total), quando comparamos com outros trabalhos realizados em zoológicos ao redor do mundo: 12 espécies ${ }^{153}$ e 16 espécies ${ }^{149}$ em duas instituições nos Estados Unidos; 3 espécies na Nova Zelândia ${ }^{95} \mathrm{e}$ 7 espécies no Japão ${ }^{96}$.

O gênero mais abundante de mosquitos encontrado foi Culex, considerado por diversos autores o principal gênero de vetor de Plasmodium ${ }^{10,}{ }^{153}$. Culex foi abundantemente encontrado em todos os recintos em que foram realizadas coletas, com exceção do Recinto Extra, onde Aedes foi mais abundante. Os lagos que existem no zoológico são considerados eutrofizados devido à grande quantidade de matéria orgânica presente em seu corpo d'água, o ambiente ideal para Culex ovipor e para as larvas crescerem. A maioria dos pontos de coleta escolhidos fica próxima a esses lagos, o que pode ter favorecido a coleta de indivíduos deste gênero. Por outro lado, o local denominado Extra situa-se em um ambiente diferenciado. Há um maior número de recintos, é cercado por edificações, apresenta grande circulação de pessoas e poucos locais de mata, se assemelhando a uma área de borda de mata degradada, diferentemente do que encontramos nos demais pontos de coleta.

É importante mencionar que na análise de LPI dos animais positivos, 22,4\% deles possivelmente se infectaram no Extra (estiveram nesse local nos 30 dias anteriores à sua detecção). Como esse local foi o de menor quantidade de mosquitos registrados, possivelmente esse não foi, de fato, o local de infecção desses animais, que deviam estar em infecção crônica há muito tempo. O Extra também foi caracterizado pela alta porcentagem de coleta de Aedes scapularis, espécie que tem 
se mostrado favorecida pela instalação de ambiente antrópico, desenvolvendo elevado grau de sinantropia ${ }^{108}$, com preferência por sangue de mamíferos, incluindo o homem, o que se confirma pela detecção neste trabalho de sangue humano no exemplar de A. scapularis encontrado ingurgitado no Bosque das Aves.

Portanto, dentro da FPZSP há uma grande diversidade de ambientes, desde áreas de mata fechada, até áreas em que há um grande número de edificações. Essa variedade de ambientes contribui para a riqueza e distribuição de mosquitos nos pontos de coleta amostrados, uma vez que cada espécie possui suas preferências de criadouros e fontes de repasto sanguíneo ${ }^{149,153}$.

Culex quinquefasciatus, considerado o principal vetor de Plasmodium, teve somente um indivíduo com espécie confirmada durante as coletas realizadas. Essa baixa prevalência também foi encontrada em zoológico na Nova Zelândia ${ }^{95}$, mas não em um zoológico americano, onde foi a espécie mais abundantemente encontrada ${ }^{153}$ sendo moderadamente presente em outro zoo nos EUA e no Japão ${ }^{149,96}$.

Apenas um indivíduo do gênero Limatus foi observado durante este estudo, capturado no recinto 61, o que poderia nos levar a considerar esta como sendo uma espécie rara. Entretanto, o esforço amostral esteve limitado a um único mês do ano, não sendo possível afirmar que essa população de Culicidae é a característica da FPZSP. Mais estudos se fazem necessários para compreender se há flutuações na população entre as estações do ano e entre os locais amostrados. A disponibilidade de locais adequados de postura de ovos e desenvolvimento de larvas é essencial para que algumas espécies de Culicidae se desenvolvam.

O Recinto 38 foi o local com a maior diversidade de gêneros, apresentando inclusive indivíduos do gênero Uranotaenia e Coquillettidia, encontrados apenas neste local. Esses gêneros, além de Mansonia, possuem uma característica importante que é o fato de se reproduzirem em locais com grande quantidade de macrófitas flutuantes, uma vez que retiram do tecido vegetal o oxigênio necessário para as trocas gasosas. Próximo ao ponto de coleta há dois recintos em que a presença dessa vegetação é abundante, criando local adequado para a presença desses gêneros. Nesse local, também é possível encontrar uma maior variedade de fontes de repasto sanguíneo, uma vez que há aves, répteis e mamíferos vivendo próximos, atraindo não apenas espécie antropofílicas, mas uma maior variedade de Culicidae. 
O estudo de fontes de repasto sanguíneo em mosquitos é bem difícil de ser realizado em ambientes naturais, principalmente devido a impossibilidade de se determinar a capacidade de voo dos mosquitos com relação as suas fontes de repasto. Entretanto, quando esse estudo é realizado em zoológicos, onde os animais possuem locais fixos de moradia e pela presença de animais exóticos, é possível estimar sua distância de voo e a capacidade de dispersão dos parasitas que eles podem carregar, além da disponibilidade de locais para oviposição ${ }^{96,153}$.

No total, foi possível coletar $1,5 \%$ de fêmeas ingurgitadas dentre os mosquitos amostrados. Esse número é o triplo de outros estudos envolvendo vetores de Plasmodium realizado em região de clima temperado ${ }^{152}$, mas semelhante a estudo realizado em um zoológico dos Estados Unidos, com 2,2\% de ingurgitados ${ }^{153}$. Por outro lado, há estudos com uma porcentagem de ingurgitados superior a 30\% ${ }^{96}$.

Apesar de alguns fragmentos de DNA utilizados para a identificação da fonte de repasto sanguíneo serem pequenos ${ }^{109}$, todos os primers utilizados neste estudo são amplamente utilizados por outros autores e indicados para fins de identificação de fonte de repasto sanguíneo. Entretanto, a análise das sequências precisa sempre ser feita com cautela, uma vez que a identificação da fonte de repasto sanguíneo depende da alimentação dos bancos de dados com informações confiáveis. Caso as sequências de uma determinada espécie estejam ausentes nesses bancos, a análise poderá apresentar um viés e poderá ser prejudicada.

Uma das sequências encontradas apresentou 99\% de identidade com Ardea herodias, uma espécie de ocorrência na América do Norte e Central, e com registros no Brasil duvidosos. Em levantamento de avifauna realizado recentemente no PEFI esta espécie não apareceu, mas foram encontrados indivíduos da espécie $A$. cocoi, uma espécie muito parecida (Daniel Perella, comunicação pessoal). Portanto, a maior similaridade com A. herodias pode ser devido à ausência de sequencias do gene citocromo b de A. cocoi no banco de dados utilizado (GenBank). Há também a possibilidade de que haja algum problema de taxonomia com o grupo de Ciconiiformes, ou mesmo que o relógio molecular que separe as duas espécies ainda não tenha se manifestado em regiões do DNA ainda muito conservadas, como é o caso do gene utilizado para este estudo. Situação semelhante a esta é encontrada para o mosquito que foi positivo para Cathartes melanbrotus (urubu-da-mata), ave de 
ocorrência na região amazônica, não sendo encontrada na cidade de São Paulo ou vivendo cativa no zoológico. A única espécie de urubu de vida livre encontrada no PEFI é a Coragyps atratus (urubu-de-cabeça-preta) (Daniel Perella, comunicação pessoal) e em cativeiro na FPZSP é Sarcoramphus papa.

A distância de voo de mosquitos ingurgitados pode variar consideravelmente. No local de estudo foi encontrado um mosquito contendo DNA de Hippopotamus amphibius localizado a cerca de $800 \mathrm{~m}$ do recinto onde o mosquito foi capturado ${ }^{47}$. Em um zoológico dos Estados Unidos, essa distância média foi de $106,7 \mathrm{~m}^{153}$ e 30,6m para fêmeas ingurgitadas e de 350m para fêmeas grávidas em zoológico do Japão ${ }^{96}$.

Mosquitos que realizaram repasto sanguíneo em Pipile jacutinga e Pavo muticus foram encontrados no Bosque das Aves, o que já era esperado, uma vez que essas espécies de aves são cativas e ficam alocadas em recintos somente no ponto amostrado. Mosquitos positivos para Cygnus atratus foram encontrados no Recinto 69 e na Ponte, pontos que ficam localizados nas margens dos lagos e onde esses cisnes são encontrados em abundância. Por outro lado, foi encontrado no Bosque das Aves um mosquito que realizou repasto sanguíneo em Spizaetus ornatos. Essa espécie é encontrada somente em recintos que ficam no mínimo a 100 m (Extra) e 300 m (Recinto 113) de distância deste local. Situação semelhante a essa é encontrada com um mosquito positivo para Cygnus atratus coletado no Bosque das Aves. O recinto onde esses animais ficam alocados fica em torno de 200 a $1000 \mathrm{~m}$ de distância. Entretanto, o Bosque das Aves fica localizado próximo ao Setor de Aves, local onde são mantidos animais que estão em tratamento veterinário, que necessitem de cuidados especiais ou mesmo de filhotes criados pelos técnicos do zoológico e que, em algum momento, pode ter recebido animais dessas espécies.

A detecção de sangue de Nycticorax nycticorax em fêmeas de Culicidae corrobora com dados encontrados previamente no local de estudo ${ }^{47}$, e aumenta as suspeitas da capacidade mosquitos de transmitir parasitas entre os indivíduos cativos e de vida livre. As linhagens DENVID01 e NYCNYC01, além de P. elongatum foram encontradas em aves de vida livre ${ }^{49}$ e cativas, ressaltando a importância de se manter os animais positivos em locais livres de mosquitos durante o tratamento.

DNA proveniente do sangue não foi detectado em 19,4\% dos mosquitos ingurgitados, impossibilitando a determinação da fonte de repasto sanguíneo. 
Entretanto, vários trabalhos mostram a impossibilidade de identificação da fonte de repasto em todos os mosquitos encontrados ingurgitados mesmo utilizando diferentes técnicas. Taxas como $37,5 \%^{154}, 27 \%^{116}, 39,3 \%^{96}, 44,4 \%^{47}$ e $17,4 \%^{114}$ de falha já foram descritas nos mosquitos ingurgitados. Após a realização do repasto sanguíneo o sangue já começa a ser digerido, e quanto maior o tempo após a realização do repasto e a coleta do indivíduo, menores as chances de se detectar o DNA ${ }^{155}$. Também há a possibilidade da fêmea se alimentar de néctar de flores, seiva e frutas, fontes importantes de carboidrato e obtenção de energia ${ }^{156}$.

A espécie de mosquito com a maior prevalência de exemplares ingurgitados foi Culex declarator. Essa espécie não foi sequer encontrada ingurgitada em estudo realizado em outros sete parques do Estado de São Paulo ${ }^{114}$.

Os Zoológicos ao redor do mundo estão localizados em grandes áreas e a simples troca de recinto do animal pela necessidade de tratamento veterinário, pareamento com outros indivíduos ou manutenção dos recintos, pode ser suficiente para que mosquitos se infectem e transmitam para outros animais. $\mathrm{O}$ conhecimento dos animais positivos e o correto manejo durante o tratamento e até que a infecção se confirme negativa é essencial para diminuir o risco de transmissão dos parasitas. Além disso, há também a necessidade de se realizar o tratamento de infecções crônicas, diminuindo as taxas de transmissão durante o ano.

Quando em cativeiro, a longevidade dos animais aumenta quando comparado com vida livre, e quanto mais tempo o hospedeiro vive, maiores as chances de que ele seja infectado. Assim, torna-se essencial o conhecimento de como as infecções crônicas podem afetar esses indivíduos para, dessa forma, garantir qualidade de vida, mantendo a capacidade reprodutiva e a longevidade desses indivíduos. Com todos os cuidados dispensados aos animais cativos, as infecções crônicas podem ser comuns e podem alterar o fitness reprodutivo dos animais, diminuindo a produção dos ovos e comprometendo a nova geração $^{73,147}$, questões extremamente importantes em programas de conservação. Outro ponto que deve ser considerado é a realização da avaliação de infecções por hemoparasitas com uso de técnicas mais sensíveis, como o PCR, antes da troca de animais entre instituições. Atualmente essa exigência não consta nos protocolos de quarentena e a introdução de parasitas em populações imunologicamente suscetíveis pode ser devastadora, como ocorreu no Havaí ${ }^{69}$. Este 
estudo utilizou técnicas laboratoriais muito utilizadas em centros de pesquisas. Entretanto, a realização de exames laboratoriais periódicos é uma realidade ainda distante na grande maioria dos zoológicos brasileiros, apenas algumas instituições possuem infraestrutura e técnicos especializados para tal tarefa. Essa deficiência pode ser superada através da criação de centros de referência para diagnóstico de determinadas doenças que possam colocar em risco a biodiversidade espécies ameaçadas.

Variações sazonais na prevalência de doenças transmitidas por vetores são bem documentadas. Neste trabalho, apesar de não termos encontrado diferenças significativas, foi verificada uma maior positividade durante os meses de verão em comparação às outras estações, como tem sido encontrado em outros estudos brasileiros $^{44}$. Para verificar se fatores climáticos incomuns poderiam ter influenciado a nossa amostragem, examinamos a média de precipitação e a média mínima de temperatura durante o período do estudo. Esses dados foram obtidos da estação meteorológica do Instituto de Astronomia, Geofísica e Ciências Atmosféricas de São Paulo, da Universidade de São Paulo (http://www.estacao.iag.usp.br/), localizada também no PEFI. Segundo esses registros, durante o período do estudo houve um ano incomum em termos de precipitações, mas esse não alterou significativamente a combinação dos períodos. Por outro lado, a coleta de uma grande quantidade de amostras durante os meses de outono em virtude de atividades de manejo realizadas com animais que vivem nos lagos do zoológico, pode ter influenciado esses resultados.

Condições ambientais exercem uma grande influência na distribuição dos vetores de hemosporídeos. Em geral os parasitas não se desenvolvem abaixo de $15^{\circ} \mathrm{C}$ e é possível confirmar a diminuição do número de casos durante os meses de inverno $^{13}$. Além das baixas temperaturas, essas estações são caracterizadas, nas regiões tropicais, por baixas precipitações, o que influencia as populações de vetores que fazem oviposição em corpos d'água e em locais passíveis de alagação. Neste estudo de mais de quatro anos foi possível detectar certa periodicidade, com o aumento do número de casos logo após o fim o verão, quando os níveis de precipitação diminuem. Apesar disso, seria importante para o controle das infecções, a utilização de estratégias de controle de vetor durante o ano todo e que não tragam 
riscos aos animais cativos e de vida livre. Há alguns relatos de medidas de controle de vetores em outros zoológicos por meio de peixes como o Gambusia sp. e larvicidas como o Bacillus thuringiensis var. israelenses (Bti) ou o Bacillus sphaericus na água dos locais onde os pássaros vivem ${ }^{76,148,149}$. No caso da FPZSP, estuda-se a melhor estratégia para ser utilizada com a finalidade de diminuir a abundância de mosquitos e reduzir a prevalência de hemosporídeos na região. 


\section{CONCLUSÕES}

a) Foi possível identificar morfologicamente Plasmodium nucleophilum, Plasmodium elongatum, Haemoproteus columbae e Haemoproteus ortalidum;

b) Vinte e uma linhagens de Plasmodium e Haemoproteus foram identificadas, das quais 12 são novas descrições. Entretanto, foi possível identificar geneticamente somente as espécies das linhagens DENPET03, GRW06, COLIV03, HAECOL1, COQUI05 e PENOBS01;

c) Este estudo foi capaz de estabelecer o código de barras de DNA para Plasmodium nucleophilum, Haemoproteus columbae e para Haemoproteus ortalidum;

d) PCR mostrou-se mais sensível para detecção de hemosporídeos em aves, enquanto que o esfregaço sanguíneo foi o único método capaz de detectar coinfecções;

e) A diversidade de espécies de Culicidae encontradas foi maior do que as já descritas em outros zoológicos pelo mundo, com 21 espécies e grande participação de espécies do gênero Culex, distribuídas amplamente pelo zoo;

f) Diversas espécies de aves cativas e de vida livre foram encontradas como fonte de repasto sanguíneo e sangue humano foi encontrado em $32,3 \%$ dos mosquitos ingurgitados. 


\section{CONSIDERAÇÕES FINAIS}

Zoológicos possuem um importante papel na conservação das espécies, mas parasitas estão constantemente presentes. Nossos resultados demonstraram que entre os animais cativos, há muitas espécies em risco de adquirir malária aviária. Por isso, é importante o estabelecimento de protocolos de quarentena para os animais que serão transferidos entre instituições, evitando a transmissão e introdução de parasitas em novos locais. Ainda, como é impossível prevenir o contato entre vetores e aves de vida livre e cativas, a elaboração de protocolos preventivos, como periodicidade de exames, isolamento e tratamento dos animais infectados é essencial.

Embora algumas espécies de hemosporídeos tenham sido identificadas, a maioria dos parasitas detectados nesse estudo representam espécies ainda não descritas. Assim, para realizar a identificação morfológica de algumas linhagens, infecções experimentais serão necessárias, pois são consideradas a forma mais eficiente para obtenção de todos os estágios sanguíneos indispensáveis para descrição de novas espécies. Este passo será importante, uma vez que há uma lacuna das espécies de hemosporídeos no Brasil que precisa ser preenchida.

Por outro lado, a complementação deste estudo se dará também com a pesquisa de hemosporídeos nos mosquitos aqui coletados, visando incriminar os potenciais vetores da malária aviária na região e obter as taxas de infectividade dos mesmos. Juntamente com as análises de hábito alimentar e com o uso de tecnologias de georreferenciamento, pretendemos obter um melhor conhecimento do comportamento dos mosquitos do zoo, podendo implementar métodos de controle que visem proteger os animais e a população humana que visita essas atrações. 


\section{REFERÊNCIAS BIBLIOGRÁFICAS}

1. Olney PJ, editor. Building a future for wildlife: the world zoo and aquarium conservation strategy. Bern: WAZA; 2005.

2. Primarck BR, Rodrigues E. Biologia da conservação. Londrina: Planta; 2001.

3. Silva JC, Corrêa SH. Manejo sanitário e biosseguridade. In: Cubas ZS, Silva JCR, Catão-Dias JL. Tratado de animais selvagens: medicina veterinária. São Paulo: Roca; 2006. p.1226-44.

4. Mukhin A, Palinauskas V, Platonova E, Kobylkov D, Vakoliuk I, Valkiūnas G. The strategy to survive primary malaria infection: an experimental study on behavioural changes in parasitized birds. PLoS One. 2016;11(7):e0159216.

5. Smith KF, Acevedo-Whitehouse K, Pederson AB. The role of infectious diseases in biological conservation. Anim Conserv. 2009;12:1-12.

6. Thompson RCA, Lymbery AJ, Smith A. Parasites, emerging disease and wildlife conservation. Int J Parasitol. 2010;40(10):1163-70.

7. Wobeser GA. Parasitism: costs and effects. In: Atkinson CT, Thomas NJ, Hunter DB. Parasitic diseases of wild birds. Ames: Wiley-Blackwell Publishing; 2008.

8. Panayotova-Pencheva MS. Parasites in captive animals: a review of studies in some European zoos. Zool Garten NF. 2013;82:60-71.

9. Marzal A, Ricklefs RE, Valkiūnas G, Albayrak T, Arriero E, Bonneaud C, et al. Diversity, Loss, and Gain of Malaria Parasites in a Globally Invasive Bird. PLoS One. 2011;6(7): e21905.

10. Valkiūnas G. Avian malaria parasites and other haemosporidia. New York: CRC Press; 2005.

11. Braga EM, Fontes CJ. Plasmodium: Malária. In: Neves DP. Parasitologia humana. São Paulo: Atheneu; 2005. p.143-82.

12. Sá MR. Os estudos em malaria aviária e o Brasil no contexto científico internacional (1907-1945). Hist Cienc Saúde Manguinhos. 2011;18(2):499-518. 
13. Santiago-Alarcon D, Palinauskas V, Schaefer HM. Diptera vectors of avian Haemosporidian parasites: untangling parasite life cycles and their taxonomy. Biol Rev Camb Philos Soc. 2012;87(4):928-64.

14. Curotto SM, Silva TG, Basso FZ, Barros Filho IR. Malária em mamíferos silvestres. Arq Ciênc Vet Zool. 2012;15(1):67-77.

15. Pérez-Tris J, Hasselquist D, Hellgren O, Krizanauskiene A, Waldenström J, Bensch S. What are malaria parasites? Trends Parasitol. 2005;21(5):209-11.

16. Krone O, Priemer J, Streich J, Sömmer P, Langgemach $\mathrm{T}$, Lessow $\mathrm{O}$. Haemosporida of birds of prey and owls from Germany. Acta Protozol. 2001;40:281-289.

17. Shurulinkov P, Golemansky V. Haemoproteids (Haemosporida: Haemoproteidae) of wild birds in Bulgaria. Acta Protozol. 2002;41:359-74.

18. Shurulinkov P, Golemansky V. Plasmodium and Leucocytozoon (Sporozoa: Haemosporida) of wild birds in Bulgaria. Acta Protozol. 2003;42:205-14.

19. Valkiūnas G, Bensch S, Iezhova TA, Krizanauskiené A, Hellgren O, Bolshakov $\mathrm{CV}$. Nested cytochrome b polymerase chain reaction diagnostics underestimate mixed infections of avian blood haemosporidian parasites: microscopy is still essential. J Parasitol. 2006;92(2):418-22.

20. Krone O, Waldenström J, Valkiūnas G, Lessow O, Müller K, Iezhova TA, et al. Haemosporidian blood parasites in European birds of prey and owls. J Parasitol. 2008;94(3):709-15.

21. Yohannes E, Križanauskiené A, Valcu M, Bensch S, Kempenaers B. Prevalence of malaria and related haemosporidian parasites in two shorebird species with different winter habitat distributions. J Ornithol. 2009;150:287-91.

22. Zehtindjiev P, Križanauskiené A, Scebba S, Dimitrov D, Valkiūnas G, Hegemann A, et al. Haemosporidian infections in skylarks (Alauda arvensis): a comparative PCR-based and microscopy study on the parasite diversity and prevalence in southern Italy and the Netherlands. Eur J Wildl Res. 2011;58:33544.

23. Piersma T, Velde MV. Dutch house martins Delichon urbicum gain blood parasite infections over their lifetime, but do not seem to suffer. J Ornithol. 2012;153:907-12.

24. Dimitrov D, Zehtindjiev P, Bensch S, Ilieva M, Iezhova T, Valkiūnas G. Two new species of Haemoproteus Kruse, 1890 (Haemosporida, Haemoproteidae) 
from European birds, with emphasis on DNA barcoding for detection of haemosporidians in wildlife. Syst Parasitol. 2014;87(2):135-51.

25. Valkiūnas G, Palinauskas V, Ilgūnas M, Bukauskaitė D, Dimitrov D, Bernotienè $\mathrm{R}$, et al. Molecular characterization of five widespread avian haemosporidian parasites (Haemosporida), with perspectives on the PCR-based detection of haemosporidians in wildlife. Parasitol Res. 2014;113(6):2251-63.

26. Yoshimura A, Koketsu M, Bando H, Saiki E, Suzuki M, Watanabe Y, et al. Phylogenetic comparison of avian haemosporidian parasites from resident and migratory birds in northern Japan. J Wildl Dis. 2014;50(2):235-42.

27. Scaglione FE, Pregel P, Cannizzo FT, Pérez-Rodríguez AD, Ferroglio E, Bollo E. Prevalence of new and known species of haemoparasites in feral pigeons in northwest Italy. Malar J. 2015;14:99.

28. Scaglione FE, Canizoo FT, Chiappino L, Sereno A, Ripepi M, Salamida S, et al. Plasmodium spp. in a captive raptor collectin of a safaripark in northwest Italy. Res Vet Sci. 2016;104:123-5.

29. Durrant KL, Beadell JS, Ishtiaq F, Graves GR, Olson SL, Gering E. Avian hematozoa in South America: a comparison of temperate and tropical zones. Ornithol Monogr. 2006;60:98-111.

30. Londoño A, Pulgarin RP, Blair S. Blood parasites in birds from the lowlands of northern Colombia. Caribb J Sci. 2007;43:87-93.

31. Mantilla JS, González AD, Valkiūnas G, Moncada LI, Matta NE. Description and molecular characterization of Plasmodium (Novyella) unalis sp. nov. from the Great Thrush (Turdus fuscater) in highland of Colombia. Parasitol Res. 2013;112(12):4193-204.

32. Mantilla JS, Matta NE, Pacheco MA, Escalante AA, González AD, Moncada LI. Identification of Plasmodium (Haemamoeba) lutzi (Lucena, 1939) from Turdus fuscater (Great Thrush) in Colombia. J Parasitol. 2013;99(4):662-8.

33. Matta NE, Pacheco MA, Escalante AA, Valkiūnas G, Ayerbe-Quiñones F, Acevedo-Cendales LD. Description and molecular characterization of Haemoproteus macrovacuolatus n. sp. (Haemosporida, Haemoproteidae), a morphologically unique blood parasite of black-bellied whistling duck (Dendrocygna autumnalis) from South America. Parasitol Res. 2014;113(8):2991-3000.

34. Mantilla JS, González AD, Lotta IA, Moens M, Pacheco MA, Escalante AA, et al. Haemoproteus erythrogravidus n. sp. (Haemosporida, Haemoproteidae): 
Description and molecular characterization of a widespread blood parasite of birds in South America. Acta Trop. 2016;159:83-94.

35. Ribeiro SF, Sebaio F, Branquinho FC, Marini MA, Vago AR, Braga EM. Avian malaria in Brazilian passerine birds: parasitism detected by nested PCR using DNA from stained blood smears. Parasitology. 2005;130(Pt 3):261-7.

36. Fecchio A, Marini MA, Braga EM. Baixa prevalência de hemoparasitos em aves silvestres no Cerrado do Brasil Central. Neotrop Biol Conserv. 2007;2:127-35.

37. Belo NO, Pineiro RT, Reis ES, Ricklefs RE, Braga EM. Prevalence and lineage diversity of avian haemosporidians from three distinct cerrado habitats in Brazil. PLoS One. 2011;6(3):e17654.

38. Fecchio A, Lima MR, Silveira P, Braga EM, Marini MA. High prevalence of blood parasites in social birds from neotropical savanna in Brazil. EMU. 2011;111:132-8.

39. Motta RO, Marques MV, Ferreira Junior FC, Andery DA, Horta RS, Peixoto $\mathrm{RB}$, et al. Does haemosporidian infection affect hematological and biochemical profiles of the endangered black-fronted piping-guan (Aburria jacutinga)? PeerJ. 2013;1:e45.

40. Silveira P, Belo NO, Lacorte GA, Kolesnikovas CK, Vanstreels RE, Steindel M, et al. Parasitological and new molecular-phylogenetic characterization of the malaria parasite Plasmodium tejerai in South American penguins. Parasitol Int. 2013;62(2):165-71.

41. Lacorte GA, Felix GM, Pinheiro RR, Chaves AV, Almeida-Neto G, Neves FS, et al. Exploring the diversity and distribution of neotropical avian malaria parasites: a molecular survey from Southeast Brazil. PLoS One. 2013;8(3):e57770.

42. Vanstreels RE, Kolesnikovas CK, Sandri S, Silveira P, Belo NO, Ferreira Junior FC, et al. Outbreak of avian malaria associated to multiple species of plasmodium in magellanic penguins undergoing rehabilitation in Southern Brazil. PLoS One. 2014;9(4):e94994.

43. Tostes R, Vashit U, Scopel KK, Massard CL, Daemon E, D’Agosto M. Plasmodium spp. and Haemoproteus spp. infection in birds of the Brazilian Forest detected by microscopy and polymerase chain reaction. Pesq Vet Bras 2015;35(1):67-74. 
44. Vanstreels RE, da Silva-Filho RP, Kolesnikovas CK, Bhering RC, Ruoppolo V, Epiphanio S, et al. Epidemiology and pathology of avian malaria in penguins undergoing rehabilitation in Brazil. Vet Res. 2015;46:30.

45. Bennett GF, Lopes OS. Blood Parasites of some birds from São Paulo State, Brazil. Mem Inst Oswaldo Cruz. 1980;75:117-34.

46. Woodworth-Lynas CB, Caines JR, Bennett GF. Prevalence of avian haematozoa in São Paulo State, Brazil. Mem Inst Oswaldo Cruz. 1989;84(4):515-26.

47. Bueno MG, Lopez RPG, Menezes RMT, Costa-Nascimento MJ, Lima GFMC, Araújo RAS, et al. Identification of Plasmodium relictum causing mortality in penguins (Spheniscus magellanicus) from São Paulo Zoo, Brazil. Vet Parasitol. 2010;173(1-2):123-7.

48. Chagas CRF, Valkiūnas G, Nery CVC, Henrique PC, Gonzalez IHL, Monteiro $\mathrm{EF}$, et al. Plasmodium (Novyella) nucleophilum from egyptian goose in São Paulo Zoo, Brazil: microscopic confirmation and molecular characterization. Int J Parasitol Parasites Wildl. 2013;2:286-91.

49. Chagas CR, Guimarães LO, Monteiro EF, Valkiūnas G, Katayama MV, Santos SV, et al. Hemosporidian parasites of free-living birds in the São Paulo Zoo, Brazil. Parasitol Res. 2016;115(4):1443-52.

50. Reis J, Nobrega P. Tratado de doenças em aves. $2^{\mathrm{a}}$ ed. São Paulo: Melhoramentos; 1956.

51. Benning TL, LaPointe D, Atkinson CT, Vitousek PM. Interactions of climate change with biological invasions and land use in the Hawaiian Islands: modeling the fate of endemic birds using a geographic information system. Proc Natl Acad Sci USA. 2002;99(22):14246-9.

52. Clark NJ, Clegg SM, Lima MR. A review of global diversity in avian haemosporidians (Plasmodium and Haemoproteus: Haemosporida): new insights from molecular data. Int J Parasitol. 2014;44(5):329-38.

53. Bensch S, Hellgren O, Pérez-Tris J. MalAvi: a public database of malaria parasites and related haemosporidians in avian hosts based on mitochondrial cytochrome b lineages. Mol Ecol Resour. 2009;9(5):1353-8.

54. Glaizot O, Fumagalli L, Iritano K, Lalubin F, Van Rooyen J, Christe P. High prevalence and lineage diversity of avian malaria in wild populations of great tits (Parus major) and mosquitoes (Culex pipiens). PLoS One. 2012;7(4):e34964. 
55. Howe L, Castro IC, Schoener ER, Hunter S, Barraclough RK, Alley MR. Malaria parasites (Plasmodium spp.) infecting introduced, native and endemic New Zealand birds. Parasitol Res. 2012;110(2):913-23.

56. Zamora-Vilchis I, Williams SE, Johnson CN. Environmental temperature affects prevalence of blood parasites of birds on an elevation gradient: implications for disease in a warming climate. PLoS One. 2012;7(6):e39208.

57. van Rooyen J, Lalubin F, Glaizot O, Christe P. Avian haemosporidian persistence and co-infection in great tits at the individual level. Malar $\mathrm{J}$. 2013;12:40.

58. Martinsen ES, Perkins SL. The diversity of Plasmodium and other haemosporidians: the intersection of taxonomy, philogenetics and genomics. In: Carlton JM, Perkins SL, Deitsch KW (editors). Malaria parasites: comparative genomics, evolution and molecular biology. Norfolk: Caister Academic Press; 2013. p. 1-15.

59. Perkins SL. Malaria's many mates: past, present, and future of the systematic of the Order Haemosporida. J Parasitol. 2014;100:11-25.

60. Atkinson CT. Avian Malaria. In: Atkinson CT, Thomas NJ, Hunter DB. Parasitic diseases of wild birds. Ames: Wiley-Blackwell Publishing; 2008. p. 3553.

61. Gager AB, Loaiza JD, Dearborn DC, Bermingham E. Do mosquitoes filter the access of Plasmodium cytochrome $b$ lineages to an avian host? Mol Ecol. 2008;17(10):2552-61.

62. Njabo KY, Cornel AJ, Sehgal RN, Loiseau C, Buermann W, Harrigan RJ, et al. Coquillettidia (Culicidae, Diptera) mosquitoes are natural vectors of avian malaria in Africa. Malar J. 2009;8:193.

63. Carlson JS, Martínez-Gómez JE, Cornel A, Loiseau C, Sehgal RN. Implications of Plasmodium parasite infected mosquitoes on an insular avifauna: the case of Socorro Island, México. J Vector Ecol. 2011;36(1):213-20.

64. Loaiza JR, Miller MJ. Seasonal pattern of avian Plasmodium-infected mosquitoes and implications for parasite transmission in central Panama. Parasitol Res. 2013;112(11):3743-51.

65. Bennett GF, Bishop MA, Peirce MA. Checklist of the avian species of Plasmodium Marchiafava \& Celli, 1885 (Apicomplexa) and their distribution by avian family and Wallacean life zones. Syst Parasitol. 1993;26:171-9. 
66. Braga EM, Silveira P, Belo NO, Valkiūnas G. Recent advances in the study of avian malaria: an overview with an emphasis on the distribution of Plasmodium spp. in Brazil. Mem Inst Oswaldo Cruz. 2011;106 Suppl 1:3-11.

67. Silva-Filho RP, Ruoppolo V. Sphenisciformes. In: Cubas ZS, Silva JC, CatãoDias JL. Tratado de animais selvagens: medicina veterinária. São Paulo: Roca; 2006. p. 309-23.

68. Van Riper III C, Van Riper SG, Goff ML, Laird M. The epizootiology and ecological significance of malaria in Hawaiian land birds. Ecol Monogr. 1986;56(4):327-44.

69. Van Riper III C. The impact of introduced vectors and avian malaria on insular passeriform bird population in Hawaii. Bull. Soc Vector Ecol. 1991;16:59-83.

70. Greiner EL, Ritchie BW. Parasites. In: Ritchie BW, Harrison GJ, Harrison LR. Avian medicine: principles and application. Lake Worth: Wingers Publishing; 1994. p. 1007-29.

71. Vanstreels RE, Parsons NJ. Malária aviária e outras hemosporidioses aviárias. In: Cubas ZS, Silva JCR, Catão-Dias JL. Tratado de animais selvagens: medicina veterinária. $2^{\text {a }}$ ed. São Paulo: Roca; 2014. p. 1427-43.

72. Marzal A, De Lope F, Navarro C, Møller AP. Malarial parasites decrease reproductive success: an experimental study in a passerine bird. Oecologia. 2005;142(4):541-5.

73. Knowles SC, Palinauskas V, Sheldon BC. Chronic malaria infections increase family inequalities and reduce parental fitness: experimental evidence from a wild bird population. J Evol Biol. 2010;23(3):557-69.

74. Murata K, Nii R, Sasaki E, Ishikawa S, Sato Y, Sawabe K, et al. Plasmodium (Bennettinia) juxtanucleare infection in a captive white eared-pheasant (Crossoptilon crossoptilon) at a Japanese zoo. J Vet Med Sci. 2008;70(2):203-5.

75. Belo NO, Passos LF, Júnior LM, Goulart CE, Sherlock TM, Braga EM. Avian malaria in captive psittacine birds: detection by microscopy and 18S rRNA gene amplification. Prev Vet Med. 2009;88(3):220-4.

76. Thurber MI, Gamble KC, Krebs B, Goldberg TL. Molecular detection of Plasmodium in free-ranging birds and captive flamingos (Phoenicopterus chilensis) in Chicago. J Zoo Wildl Med. 2014;45(4):749-54. 
77. Ferrell ST, Snowden K, Marlar AB, Garner M, Lung NP. Fatal hemoprotozoal infections in multiple avian species in a zoological park. J Zoo Wildl Med. 2007;38(2):309-16.

78. Vanstreels RE, Braga EM, Catão-Dias JL. Blood parasites of penguins: a critical review. Parasitol. 2016;143(8):931-56.

79. Olias P, Wegelin M, Zenker W, Freter S, Gruber AD, Klopfleisch R. Avian malaria deaths in parrots, Europe. Emerg Infect Dis. 2011;17(5):950-2.

80. Cannell BL, Krasnec KV, Campbell K, Jones HI, Miller RD, Stephens N. The pathology and pathogenicity of a novel Haemoproteus spp. infection in wild Little Penguins (Eudyptula minor). Vet Parasitol. 2013;197(1-2):74-84. Erratum in: Vet Parasitol. 2014;205(1-2):416.

81. Atkinson CT. Haemoproteus. In: Atkinson CT, Thomas NJ, Hunter DB. Parasitic diseases of wild birds. Ames: Wiley-Blackwell Publishing; 2008. p. 1334.

82. Feldman RA, Freed LA, Cann RL. A PCR test for avian malaria in Hawaiian birds. Mol Ecol. 1995;4(6):663-73.

83. Perkins SL, Schall JJ. A molecular phylogeny of malarial parasites recovered from cytochrome b gene sequences. J Parasitol. 2002;88:972-8.

84. Hellgren O, Waldenström J, Bensch S. A new pcr assay for simultaneous studies of Leucocytozoon, Plasmodium and Haemoproteus from avian blood. J Parasitol. 2004;90(4):797-802.

85. Waldenström J, Bensch S, Hasselquist D, Östman Ö. A new nested polymerase chain reaction method very efficient in detecting Plasmodium and Haemoproteus infections from avian blood. J Parasitol. 2004;90(1):191-4.

86. Bernotienè R, Palinauskas V, Iezhova T, Murauskaitė D, Valkiūnas G. Avian haemosporidian parasites (Haemosporida): A comparative analysis of diferent polymerase chain reaction assays in detection of mixed infections. Exp Parasitol. 2016;163:31-7.

87. Ilgūnas M, Palinauskas V, Iezhova TA, Valkiūnas G. Molecular and morphological characterization of two avian malaria parasites (Haemosporida: Plasmodiidae), with description of Plasmodium homonucleophilum $\mathrm{n}$. $\mathrm{sp}$. Zootaxa. 2013;3666:49-61. 
88. Valkiūnas G, Iezhova TA, Križanauskiené A, Palinauskas V, Sehgal RN, Bensch S. A comparative analysis of microscopy and pcr-based detection methods for blood parasites. J Parasitol. 2008;94(6):1395-401.

89. Zehtindjiev P, Krizanauskiene A, Bensch S, Palinauskas V, Asghar M, Dimitrov $\mathrm{D}$, et al. A new morphologically distinct avian malaria parasite that fails detection by established polymerase chain reaction-based protocols for amplification of the cytochrome b gene. J Parasitol. 2012;98(3):657-65.

90. Valkiūnas G, Atkinson CT, Bensch S, Sehgal RNM, Ricklefs RE. Parasite misidentifications in GenBank: how to minimize their number? Trends Parasitol. 2008;24(6):247-8.

91. MalAvi: a database for avian haemosporidian parasites. Lund: Lund Univerxity; 2016 [citado 2016 Mai 06]. Disponível em: http://mbioserv2.mbioekol.lu.se/Malavi/.

92. Jones JW, Turell MJ, Sardelis MR, Watts DM, Coleman RE, Fernandez R, et al. Seasonal distribution, biology and human attractant patterns of Culicine mosquitoes (Diptera: Culicidae) in a forest near Puerto Almendras, Iquitos, Peru. J Med Entomol. 2004;41:349-360.

93. Franklin DC, Whelan PI. Tropical mosquito assemblages demonstrate 'textbook' annual cycles. PLoS One. 2009;4(12):e8296.

94. Service MW. Mosquito ecology field sampling methods. $2^{\mathrm{a}}$ ed. Essex: Elsevier Science Publishers; 1993.

95. Derraik JG. A survey of the mosquito (Diptera: Culicidae) fauna of the Auckland Zoological Park. N Z Entomol. 2004;27:51-5.

96. Ejiri H, Sato Y, Kim KS, Hara T, Tsuda Y, Imura T, et al. Entomological study on transmission of avian malaria parasites in a zoological garden in Japan: bloodmeal identification and detection of avian malaria parasite DNA from blood-fed mosquitoes. J Med Entomol. 2011;48(3):600-7.

97. Estação Meteorológica do IAG. Instituto de Astronomia, Geofísica e Ciências Atmosféricas. Universidade de São Paulo. [citado 2016 Mai 18]. Disponível em: http://www.estacao.iag.usp.br/seasons/index.php

98. Clark P, Boardman WS, Raidal S. Atlas of clinical avian hematology. Ames: Wiley-Blackwell Publishing; 2009. Collection and handling of blood samples; $p$. $1-32$. 
99. Godfrey RD, Fedynich AM, Pence DB. Quantification of the hematozoa in blood smears. J Wildl Dis. 1987;23(4):558-65.

100. Bensch S, Pérez-Tris J, Waldenström J, Hellgren O. Linkage between nuclear and mitochondrial DNA sequences in avian malaria parasites: multiple cases of cryptic speciation? Evolution. 2004;58:1617-21.

101. Thompson JD, Gibson TJ, Plewniak F, Jeanmougin F, Higgins DG. The Clustal X windows interface: flexible strategies for multiple sequence alignment aided by quality analysis tools. Nucleic Acids Res. 1997;25(24):4876-82.

102. Huelsenbeck JP, Ronquist F. MRBAYES: Bayesian inference of phylogenetic trees. Bioinformatics. 2001;17(8):754-5.

103. Rambaut A. FigTree v.1v4v3v [cited 2016 Ago 10] Disponível em: http://tree.bio.ed.ac.uk/software/figtree/.

104. Bandelt HJ, Forster P, Rohl A. Median-joining networks for inferring intraspecific phylogenies. Mol Biol Evol. 1999;16(1):37-48.

105. Nasci RS. A lightweight batterypowered aspirator for collecting resting mosquitoes in the field. Mosq News. 1981;41:808-11.

106. Sella M. Relazione della campagna anti-anofelica di Flumicino (1919) con speciale riguardo alla biologia degli Anofelied agli Anofeli infetti. Ann Ig 30. 1920.

107. Sudia WD, Chamberlain RW. Battery-operated light trap, an improved model. By W. D. Sudia and R. W. Chamberlain, 1962. J Am Mosq Control Assoc. 1988;4(4):536-8.

108. Forattini, OP. Culicidologia médica: identificação, biologia, epidemiologia. São Paulo: Edusp; 2002.

109. Kocher TD, Thomas WK, Meyer A, Edwards SV, Paabo S, Villablanca FX, et al. Dynamics of mitochondrial DNA evolution in animals: amplification and sequencing with conserved primers. Proc Natl Acad Sci USA. 1989;86(16):6196-200.

110. Bonvicino CR, Lemos B, Seuánez HN. Molecular phylogenetics of howler monkeys (Alouatta, Platyrrhini). A comparison with karyotypic data. Chromosoma. 2001;110(3):241-6.

111. Pereira SL, Baker AJ. Vicariant speciation of curassows (Aves, Cracidae): a hypothesis based on mitochondrial DNA phylogeny. The Auk. 2004;121:682-94. 
112. Molaei G, Andreadis TG, Armstrong PM, Anderson JF, Vossbrinck CR. Host feeding patterns of Culex mosquitoes and West Nile virus transmission, northeastern United States. Emerg Infect Dis. 2006;12(3):468-74.

113. Chang MC, Teng HJ, Chen CF, Chen YC, Jeng CR. The resting sites and blood-meal sources of Anopheles minimus in Taiwan. Malar J. 2008;7:105.

114. de Carvalho GC, Malafronte RS, Izumisawa CM, Teixeira RS, Natal L, Marrelli MT. Blood meal sources of mosquitoes captured in municipal parks in São Paulo, Brazil. J Vector Ecol. 2014;39(1):146-52.

115. Kent RJ. Molecular methods for arthropod bloodmeal identification and applications to ecological and vector-borne disease studies. Mol Ecol Resour. 2009;9(1):4-18.

116. Kirchgatter K, Tubaki RM, Malafronte RS, Alves IC, Lima GF, Guimarães LO, et al. Anopheles (Kerteszia) cruzii (Diptera: Culicidae) in peridomiciliary area during asymptomatic malaria transmission in the Atlantic Forest: molecular identification of blood-meal sources indicates humans as primary intermediate hosts. Rev Inst Med Trop Sao Paulo. 2014;56(5):403-9.

117. Clements JF, Schulenberg TS, Iliff MJ, Roberson D, Fredericks TA, Sullivan BL, et al. The eBird/Clements checklist of birds of the world: v2016 [citado 2016 Out 14]. Disponível em: http://www.birds.cornell.edu/clementschecklist/download/

118. Fundação Parque Zoológico de São Paulo. Relatório Anual 2015: Plantel dos Animais. São Paulo: Fundação Parque Zoológico de São Paulo; 2016 [citado 2016 Jul 19] http://www.zoologico.com.br/wpcontent/uploads/2013/07/plantel_zoologico_2015-1.pdf.

119. International Union for Consrvation of Nature and National Resources. The IUCN red list of threatened species. Version 2016-2. [citado 2016 Out 14].

120. Villar CM, Bryan Junior AL, Lance SL, Braga EM, Congrains C, Del Lama SN. Blood parasites in nestlings of wood stork populations from three regions of the American continent. J Parasitol. 2013;99(3):522-7.

121. Young BB, Garvin MC, Mac Donald DB. Blood parasites in birds from Monteverde, Costa Rica. J Wildl Dis. 1993;29(4):555-60.

122. Calero-Riestra M, García JT. Sex-dependent differences in avian malaria prevalence and consequences of infections on nestling growth and adult condition in the Tawny pipit, Anthus campestris. Malar J. 2016;15:178. 
123. Beadell JS, Covas R, Gebhard C, Ishtiaq F, Melo M, Schmidt BK, et al. Host associations and evolutionary relationships of avian blood parasites from West Africa. Int J Parasitol. 2009;39(2):257-66.

124. Merino S, Hennicke J, Martínez J, Ludynia K, Torres R, Work TM, et al. Infection by Haemoproteus parasites in four species of frigatebirds and the description of a new species of Haemoproteus (Haemosporida: Haemoproteidae). J Parasitol. 2012;98(2):388-97.

125. Fantham HB, Porter A. Plasmodium struthionis, sp. n., from Sudanese ostriches and Sarcocystis salvelini, sp. n., from Canadian speckled trout (Salvelinus fontinalis), together with a record of a Sarcocystis in the eel pout (Zoarces angularis). Proc Zool Soc London. 1943;112 ser B: 25-30.

126. Clayton DH, Al-Tamimi S, Johnson KP. The ecological basis of coevolutionary history. In: Page RDM (editor). Tangled trees: phylogeny, cospeciation, and coevolution. Chicago: University of Chicago Press; 2003. p. 310-41.

127. MacLeod CJ, Paterson AM, Tompkins DM, Duncan RP. Parasites lost - do invaders miss the boat or drown on arrival? Ecol Lett. 2010;13(4):516-27.

128. Keesing F, Holt RD, Ostfeld RS. Effects of species diversity on disease risk. Ecol Lett. 2006;9(4):485-98.

129. Krasnov BR, Poulin R, Shenbrot GI, Mouillot D, Khokhlova IS. Host specificity and geographic range in haematophagous ectoparasites. Oikos. 2005;108:449-56.

130. Pérez-Tris J, Bensch S. Diagnosing genetically diverse avian malarial infections using mixed-sequence analysis and TA-cloning. Parasitology. 2005;131(Pt 1):15-23.

131. Hellgren O, Waldenström J, Peréz-Tris J, Szöll E, Si O, Hasselquist D, et al. Detecting shifts of transmission areas in avian blood parasites: a phylogenetic approach. Mol Ecol. 2007;16(6):1281-90.

132. Ceretti-Junior W, de Oliveira Christe R, Rizzo M, Strobel RC, de Matos Junior MO, de Mello MH, et al. Species composition and ecological aspects of immature mosquitoes (diptera: culicidae) in bromeliads in urban parks in the city of São Paulo, Brazil. J Arthropod Borne Dis. 2015;10(1):102-12.

133. Roos FL, Belo NO, Silveira P, Braga EM. Prevalence and diversity of avian malaria parasites in migratory Black Skimmers (Rynchops niger, Laridae, 
Charadriiformes) from the Brazilian Amazon Basin. Parasitol Res. 2015;114(10):3903-11.

134. Ricklefs RE, Fallon, SM. Diversification and host switching in avian malaria parasites. Proc Biol Sci. 2002;269(1494):885-92.

135. Szymanski MM, Lovette IJ. High lineage diversity and host sharing of malarial parasites in a local avian assemblage. J Parasitol. 2005;91(4):768-74.

136. Pagenknopp KM, Klicka J, Durrant KL, Garvin JC, Fleischer RC. Geographic variation in malaria parasite lineages in the common yellowthroat (Geothlypis trichas). Conserv Genetics. 2008;9:1577-88.

137. Levin II, Zwiers P, Deem SL, Geest EA, Higashiguchi JM, Iezhova TA, et al. Multiple lineages of Avian malaria parasites (Plasmodium) in the Galapagos Islands and evidence for arrival via migratory birds. Conserv Biol. 2013;27(6):1366-77.

138. Oakgrove KS, Harrigan RJ, Louiseau C, Guers S, Seppi B, Sehgal RN. Distribution, diversity and drivers of blood-borne parasite co-infections in Alaskan bird populations. Int J Parasitol. 2014;44(10):717-27

139. Moens MA, Pérez-Tris J. Discovering potential sources of emerging pathogens: South America is a reservoir of generalist avian blood parasites. Int $\mathbf{J}$ Parasitol. 2016;46(1):41-9.

140. Lauron EJ, Loiseau C, Bowie RC, Spicer GS, Smith TB, Melo M, Sehgal RN. Coevolutionary patterns and diversification of avian malaria parasites in African sunbirds (Family Nectariniidae). Parasitology. 2015;142(5):635-47.

141. Loiseau C, Harrigan RJ, Robert A, Bowie RC, Thomassen HA, Smith TB, et al. Host and habitat specialization of avian malaria in Africa. Mol Ecol. 2012;21(2):431-41.

142. Escalante AA, Freeland DE, Collins WE, Lal AA. The evolution of primate malaria parasites based on the gene encoding cytochrome $b$ from the linear mitochondrial genome. Proc Natl Acad Sci USA. 1998;95(14):8124-9.

143. Merino S, Moreno J, Vásquez RA, Martínez J, Sánchez-Monsálvez I, Estades, CF, et al. Haematozoa in forest birds from southern Chile: Latitudinal gradients in prevalence and parasite lineage richness. Austral Ecol. 2008;33:32940. 
144. Dodge M, Guers SL, Sekercioğlu ÇH, Sehgal RN. North American transmission of hemosporidian parasites in the Swainson's thrush (Catharus ustulatus), a migratory songbird. J Parasitol. 2013;99(3):548-53.

145. Martínez-de la Puente J, Muñoz J, Capelli G, Montarsi F, Soriguer R, Arnoldi $\mathrm{D}$, et al. Avian malaria parasites in the last supper: identifying encounters between parasites and the invasive Asian mosquito tiger and native mosquito species in Italy. Malar J. 2015;14:32.

146. González AD, Lotta IA, García LF, Moncada LI, Matta NE. Avian haemosporidians from Neotropical highlands: evidence from morphological and molecular data. Parasitol Int. 2015;64(4):48-59.

147. Asghar M, Hasselquist D, Hansson B, Zehtindjiev P, Westerdahl H, Bensch $S$. Chronic infection. Hidden costs of infection: chronic malaria accelerates telomere degradation and senescence in wild birds. Science. 2015;347(6220):436-8.

148. Derraik JG. Recommendations for mosquito control in zoological parks to reduce disease transmission risk. The Weta. 2005;26:16-20.

149. Tuten HC. Habitat characteristics of larval mosquitoes in zoos of South Carolina, USA. J Am Mosq Control Assoc. 2011 Jun;27(2):111-9.

150. Garamszegi LZ. The sensitivity of microscopy and PCR-based detection methods affecting estimates of prevalence of blood parasites in birds. J Parasitol. 2010;96(6):1197-203.

151. Richard FA, Sehgal RNM, Jones HI, Smith TB. A comparative analysis of PCR-based detection methods for avian malaria. J. Parasitol. 2002;88:819-22.

152. Bukauskaitè D, Bernotienè R, Iezhova TA, Valkiūnas G. Mechanisms of mortality in Culicoides biting midges due to Haemoproteus infection. Parasitology. 2016;143(13):1748-54.

153. Greenber JA, DiMenna MA, Hanelt B, Hofkin BV. Analysis of port-blood meal fligt in mosquitões utilizing zoo animals blood meals. J Vector Ecol. 2012;37(1):83-9.

154. Forattini OP, Gomes AC, Natal D, Kakitani I, Marucci D. Preferências alimentares e domiciliação de mosquito Culicidae no Vale do Ribeira, São Paulo, Brasil, com especial referência a Aedes scapularis e Culex (Melanoconion). Rev Saúde Pública. 1989;23:9-19. 
155. Oshaghi MA, Chavshin AR, Vatandoost H, Yaaghoobi F, Mohtarami F, Noorjah N. Effects of post-ingestion and physical conditions on PCR amplification of host blood meal DNA in mosquitoes. Exp Parasitol. 2006;112(4):232-6.

156. Foster WA. Mosquito sugar feeding and reprouctive energetics. Annu Rev Entomol. 1995;40:443-74. 
APÊNDICE A - Aves amostradas nesse estudo, amostras com resultado positivo por PCR para Plasmodium/Haemoproteus, distribuição geográfica e status de ameaça.

\begin{tabular}{|c|c|c|c|c|c|}
\hline $\begin{array}{l}\text { ORDEM } \\
\text { Família }\end{array}$ & $\begin{array}{l}\text { Espécie } \\
\text { (Nome comum) }\end{array}$ & $\begin{array}{c}\text { AVES } \\
\text { (POSITIVAS) }\end{array}$ & $\begin{array}{l}\text { AMOSTRAS } \\
\text { (POSITIVAS) }\end{array}$ & $\begin{array}{l}\text { DISTRIBUIÇÃO GEOGRÁFICA } \\
\text { (Países nativos) }\end{array}$ & $\begin{array}{c}\text { IUCN } \\
\text { STATUS }\end{array}$ \\
\hline \multicolumn{6}{|c|}{ ACCIPITRIFORMES } \\
\hline \multirow[t]{10}{*}{ Accipitridae } & $\begin{array}{l}\text { Buteogallus coronatus } \\
\text { (águia-cinzenta) }\end{array}$ & 2 & 6 & Brasil, Bolívia, Paraguai e Argentina & EN \\
\hline & $\begin{array}{l}\text { Buteogallus urubitinga } \\
\text { (gavião-preto) }\end{array}$ & $1(1)$ & $6(1)$ & América do Sul e Central & $\mathrm{LC}$ \\
\hline & $\begin{array}{l}\text { Buteogallus lacernulatus } \\
\text { (gavião-pombo-pequeno) }\end{array}$ & 4 & 5 & Brasil & VU \\
\hline & $\begin{array}{l}\text { Buteogallus meridionalis } \\
\text { (gavião-caboclo) }\end{array}$ & 2 & 6 & América do Sul e Central & $\mathrm{LC}$ \\
\hline & $\begin{array}{l}\text { Geranoaetus albicaudatus } \\
\text { (gavião-de-rabo-branco) }\end{array}$ & 2 & 2 & América do Sul e Central & $\mathrm{LC}$ \\
\hline & $\begin{array}{l}\text { Geranoaetus } \\
\text { melanoleucus } \\
\text { (águia-chilena) }\end{array}$ & 2 & 2 & América do Sul & $\mathrm{LC}$ \\
\hline & $\begin{array}{l}\text { Haliaeetus vocifer } \\
\text { (águia-pescadora-africana) }\end{array}$ & 1 & 3 & África & $\mathrm{LC}$ \\
\hline & $\begin{array}{l}\text { Harpia harpyja } \\
\text { (gavião-real) }\end{array}$ & 7 & 13 & América do Sul e Central & NT \\
\hline & $\begin{array}{l}\text { Leptodon cayanensis } \\
\text { (gavião-de-cabeça-cinza) }\end{array}$ & 1 & 1 & América do Sul e Central & $\mathrm{LC}$ \\
\hline & $\begin{array}{l}\text { Pseudastur polionotus } \\
\text { (gavião-pombo-grande) }\end{array}$ & 1 & 1 & Brasil, Uruguai e Paraguai & NT \\
\hline
\end{tabular}




\begin{tabular}{|c|c|c|c|c|c|}
\hline \multicolumn{6}{|l|}{ Continuação } \\
\hline & $\begin{array}{l}\text { Spizaetus ornatus } \\
\text { (gavião-de-penacho) }\end{array}$ & 10 & 15 & América do Sul e Central & NT \\
\hline & $\begin{array}{l}\text { Spizaetus tyrannus } \\
\text { (gavião-pega-macaco) }\end{array}$ & 6 & 10 & América do Sul e Central & $\mathrm{LC}$ \\
\hline & $\begin{array}{l}\text { Trigonoceps occipitalis } \\
\text { (abutre-de-cabeça-branca) }\end{array}$ & 1 & 5 & África & CR \\
\hline \multirow[t]{2}{*}{ Cathartidae } & $\begin{array}{l}\text { Sarcoramphus papa } \\
\text { (urubu-rei) }\end{array}$ & $6(2)$ & $10(3)$ & América do Sul e Central & $\mathrm{LC}$ \\
\hline & $\begin{array}{l}\text { Vultur gryphus } \\
\text { (condor) }\end{array}$ & 1 & 1 & América do Sul & NT \\
\hline \multicolumn{6}{|c|}{ ANSERIFORMES } \\
\hline \multirow[t]{7}{*}{ Anatidae } & $\begin{array}{l}\text { Alopochen aegyptiaca } \\
\text { (ganso-do-Egito) }\end{array}$ & $10(5)$ & $18(7)$ & África & $\mathrm{LC}$ \\
\hline & $\begin{array}{l}\text { Amazonetta brasiliensis } \\
\text { (pé-vermelho) }\end{array}$ & $4(1)$ & $8(1)$ & América do Sul & $\mathrm{LC}$ \\
\hline & $\begin{array}{l}\text { Anser cygnoides } \\
\text { (ganso-da-Sibéria) }\end{array}$ & $1(1)$ & $4(4)$ & Ásia & VU \\
\hline & $\begin{array}{l}\text { Branta canadensis } \\
\text { (ganso-canadense) }\end{array}$ & 1 & 1 & América do Norte & $\mathrm{LC}$ \\
\hline & $\begin{array}{l}\text { Cereopsis } \\
\text { novaehollandiae } \\
\text { (ganso-australiano) }\end{array}$ & $12(1)$ & $19(1)$ & Austrália & $\mathrm{LC}$ \\
\hline & $\begin{array}{l}\text { Chenonetta jubata } \\
\text { (gansinho-australiano) }\end{array}$ & 1 & 7 & Oceania & $\mathrm{LC}$ \\
\hline & $\begin{array}{l}\text { Coscoroba coscoroba } \\
\text { (capororoca) }\end{array}$ & $24(1)$ & $39(1)$ & $\begin{array}{l}\text { Brasil, Argentina, Chile, Paraguai e } \\
\text { Uruguai }\end{array}$ & $\mathrm{LC}$ \\
\hline
\end{tabular}




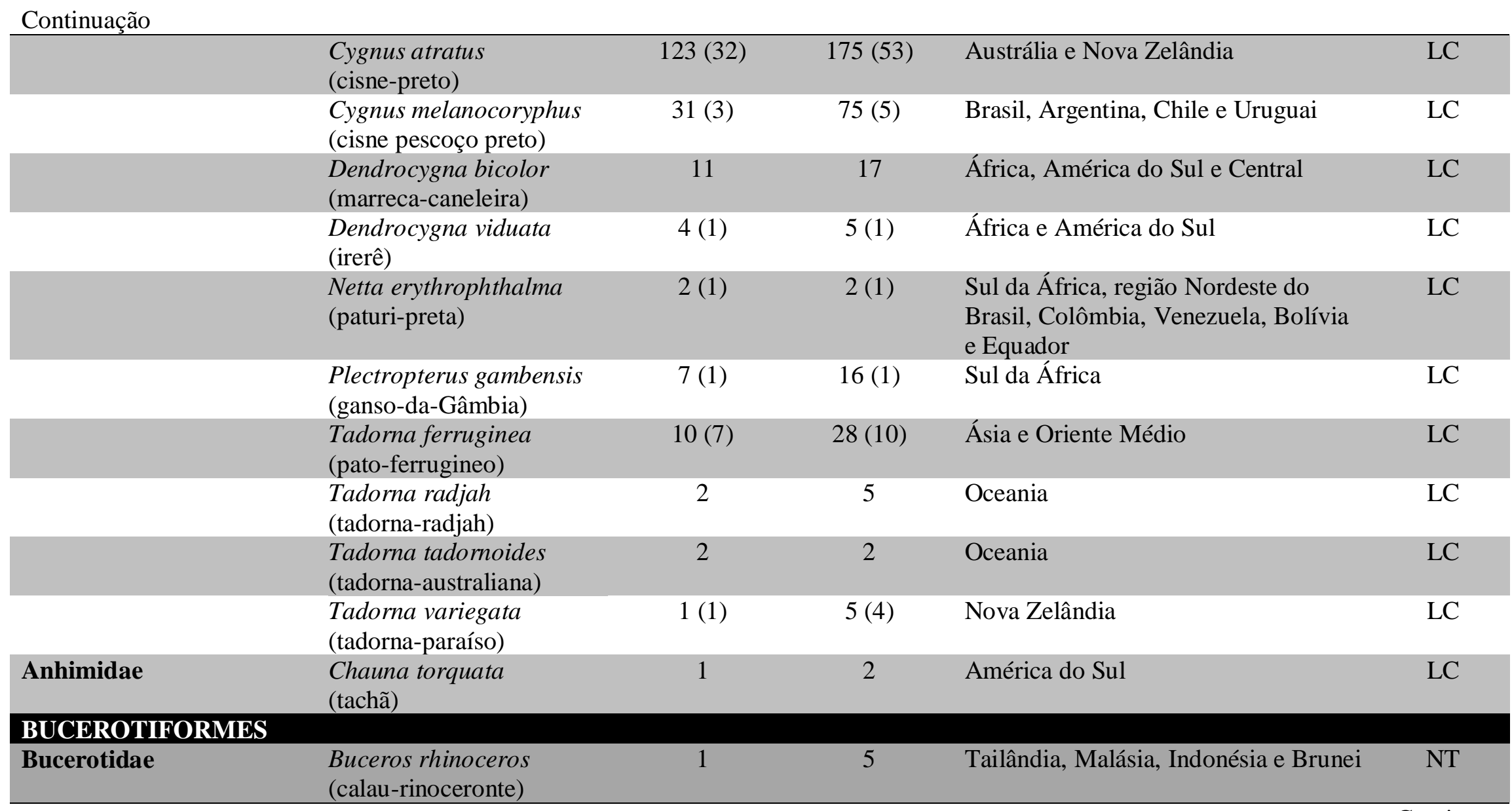




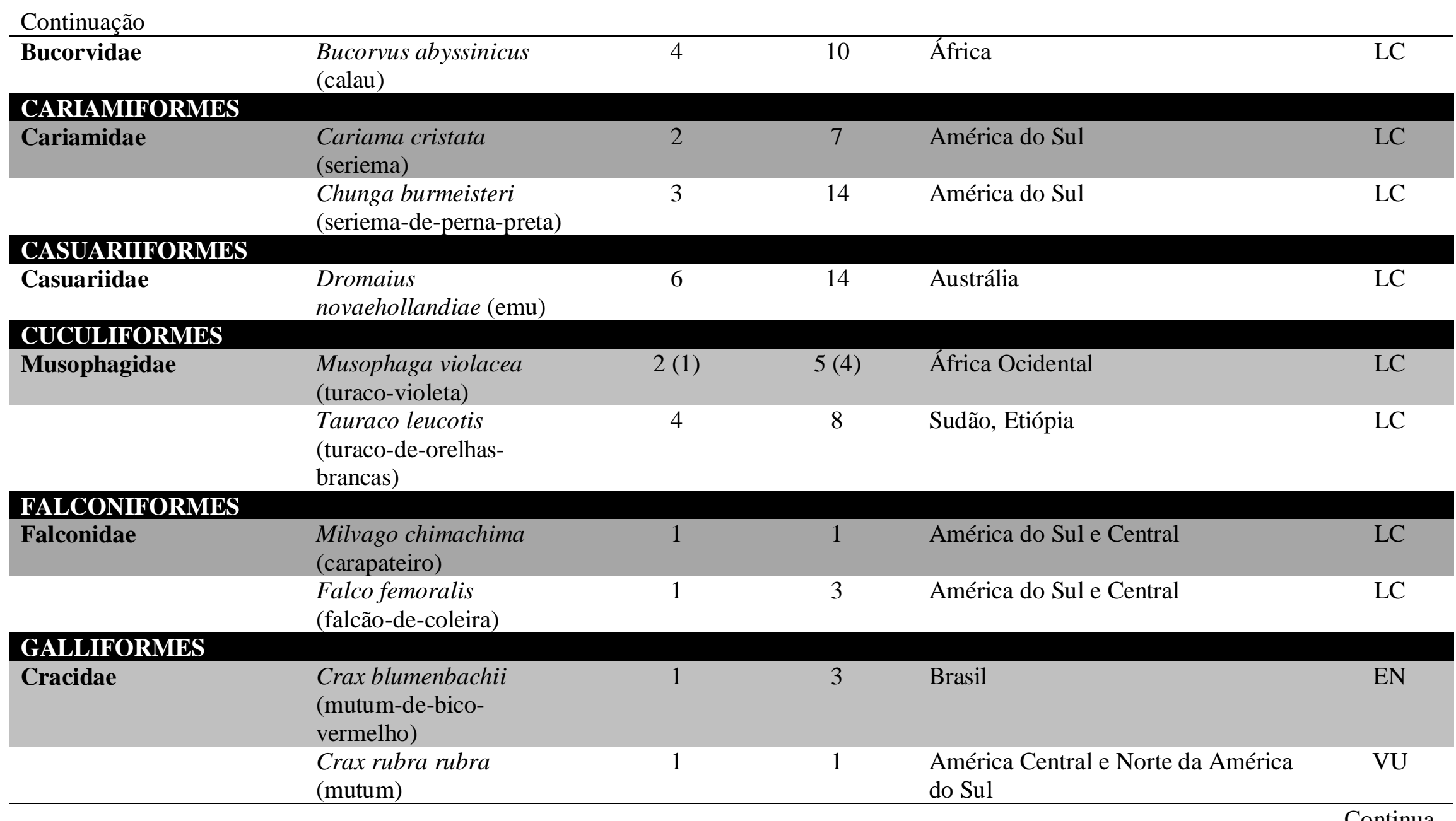




\begin{tabular}{|c|c|c|c|c|c|}
\hline Continuação & $\begin{array}{l}\text { Mitu tomentosum } \\
\text { (mutum-do-nordeste) }\end{array}$ & $5(1)$ & $10(1)$ & $\begin{array}{l}\text { Brasil, Colômbia, Guiana, Venezuela e } \\
\text { Bolívia }\end{array}$ & NT \\
\hline & $\begin{array}{l}\text { Mitu tuberosum } \\
\text { (mutum-cavalo) }\end{array}$ & 1 & 1 & América do Sul & $\mathrm{LC}$ \\
\hline & $\begin{array}{l}\text { Nothocrax urumutum } \\
\text { (urumutum) }\end{array}$ & $5(1)$ & $9(1)$ & $\begin{array}{l}\text { Brasil, Colômbia, Equador, Peru, } \\
\text { Venezuela e Bolívia }\end{array}$ & LC \\
\hline & $\begin{array}{l}\text { Penelope obscura } \\
\text { (jacu-guaçu) }\end{array}$ & $2(1)$ & $2(1)$ & $\begin{array}{l}\text { Argentina, Bolívia, Brasil, Paraguai e } \\
\text { Uruguai }\end{array}$ & $\mathrm{LC}$ \\
\hline & $\begin{array}{l}\text { Pipile jacutinga } \\
\text { (jacutinga) }\end{array}$ & $3(2)$ & $9(3)$ & Argentina, Brasil e Paraguai & $\mathrm{EN}$ \\
\hline \multirow[t]{2}{*}{ Phasianidae } & $\begin{array}{l}\text { Pavo cristatus } \\
\text { (pavão-azul) }\end{array}$ & $31(4)$ & $53(5)$ & $\begin{array}{l}\text { Bangladesh, Butão, Índia, Nepal, } \\
\text { Paquistão e Siri Lanka }\end{array}$ & $\mathrm{LC}$ \\
\hline & $\begin{array}{l}\text { Pavo muticus } \\
\text { (pavão-verde) }\end{array}$ & $4(1)$ & $7(3)$ & $\begin{array}{l}\text { Camboja, China, Indonésia, Mianmar, } \\
\text { Tailândia e Vietnã }\end{array}$ & $\mathrm{EN}$ \\
\hline Odonthophoridae & $\begin{array}{l}\text { Odontophorus capueira } \\
\text { (uru) }\end{array}$ & 3 & 3 & Argentina, Brasil e Paraguai & LC \\
\hline \multicolumn{6}{|l|}{ GRUIFORMES } \\
\hline Rallidae & $\begin{array}{l}\text { Aramides cajaneus } \\
\text { (saracura-três-potes) }\end{array}$ & $1(1)$ & $2(1)$ & América do Sul e Central & LC \\
\hline Gruidae & $\begin{array}{l}\text { Balearica regulorum } \\
\text { (grou-coroado-oriental) }\end{array}$ & 6 & 15 & África & EN \\
\hline \multicolumn{6}{|l|}{ PASSERIFORMES } \\
\hline \multirow[t]{2}{*}{ Cotingidae } & $\begin{array}{l}\text { Pyroderus scutatus } \\
\text { (pavó) }\end{array}$ & 1 & 1 & América do Sul & LC \\
\hline & $\begin{array}{l}\text { Rupicola rupicola } \\
\text { (galo-da-serra-do-pará) }\end{array}$ & 1 & 6 & Norte da América do Sul & $\mathrm{LC}$ \\
\hline
\end{tabular}




\begin{tabular}{|c|c|c|c|c|c|}
\hline Icteridae & $\begin{array}{l}\text { Psarocolius decumanus } \\
\text { (japu) }\end{array}$ & $1(1)$ & $1(1)$ & América do Sul & $\mathrm{LC}$ \\
\hline Sturnidae & $\begin{array}{l}\text { Acridotheres cristatellus } \\
\text { (mainá-de-crista) }\end{array}$ & 2 & 2 & Ásia & $\mathrm{LC}$ \\
\hline Thraupidae & $\begin{array}{l}\text { Saltator atricollis } \\
\text { (bico-de-pimenta) }\end{array}$ & $1(1)$ & $1(1)$ & Bolívia, Brasil, Paraguai & $\mathrm{LC}$ \\
\hline \multicolumn{6}{|c|}{ PELECANIFORMES } \\
\hline Pelecanidae & $\begin{array}{l}\text { Pelecanus onocrotalus } \\
\text { (pelecano-rosa) }\end{array}$ & 3 & 4 & África e Oriente Médio & $\mathrm{LC}$ \\
\hline \multirow[t]{3}{*}{ Threskionithidae } & $\begin{array}{l}\text { Eudocimus ruber } \\
\text { (guará) }\end{array}$ & $6(1)$ & $7(1)$ & $\begin{array}{l}\text { Costa do Sudeste e do Norte do Brasil, } \\
\text { Colômbia e Guianas }\end{array}$ & $\mathrm{LC}$ \\
\hline & $\begin{array}{l}\text { Platalea ajaja } \\
\text { (colhereiro) }\end{array}$ & 2 & 3 & América do Sul e Central & $\mathrm{LC}$ \\
\hline & $\begin{array}{l}\text { Theristicus caudatus } \\
\text { (curicaca) }\end{array}$ & 1 & 1 & América do Sul e Central & $\mathrm{LC}$ \\
\hline \multicolumn{6}{|c|}{$\begin{array}{l}\text { PHOENICOPTERIFOR } \\
\text { MES }\end{array}$} \\
\hline \multirow[t]{3}{*}{ Phoenicopteridae } & $\begin{array}{l}\text { Phoeniconaias minor } \\
\text { (flamingo-pequeno) }\end{array}$ & 9 & 12 & $\begin{array}{l}\text { Quênia, Tanzânia, Etiópia, Índia e } \\
\text { Paquistão }\end{array}$ & NT \\
\hline & $\begin{array}{l}\text { Phoenicopterus chilensis } \\
\text { (flamingo-chileno) }\end{array}$ & $34(3)$ & $39(4)$ & Sul da América do Sul & NT \\
\hline & $\begin{array}{l}\text { Phoenicopterus ruber } \\
\text { (flamingo-vermelho) }\end{array}$ & 6 & 6 & América do Norte, Sul e Central & LC \\
\hline \multicolumn{6}{|l|}{ PICIFORMES } \\
\hline Ramphastidae & $\begin{array}{l}\text { Pteroglossus aracari } \\
\text { (araçari-de-bico-branco) }\end{array}$ & 4 & 11 & Norte da América do Sul & $\mathrm{LC}$ \\
\hline
\end{tabular}




\begin{tabular}{|c|c|c|c|c|c|}
\hline Continuação & $\begin{array}{l}\text { Pteroglossus bailloni } \\
\text { (araçari-banana) }\end{array}$ & 3 & 7 & Argentina, Brasil e Paraguai & NT \\
\hline & $\begin{array}{l}\text { Pteroglossus castanotis } \\
\text { (araçari-castanho) }\end{array}$ & 2 & 7 & América do Sul & $\mathrm{LC}$ \\
\hline & $\begin{array}{l}\text { Ramphastos dicolorus } \\
\text { (tucano-de-bico-verde) }\end{array}$ & 4 & 14 & Argentina, Brasil e Paraguai & $\mathrm{LC}$ \\
\hline & $\begin{array}{l}\text { Ramphastos toco } \\
\text { (tucano-toco) }\end{array}$ & $4(2)$ & $12(3)$ & América do Sul & $\mathrm{LC}$ \\
\hline & $\begin{array}{l}\text { Ramphastos tucanus } \\
\text { (tucano-de-peito-branco) }\end{array}$ & 4 & 10 & América do Sul & VU \\
\hline & $\begin{array}{l}\text { Ramphastos vitellinus } \\
\text { (tucano-de-bico-preto) }\end{array}$ & $2(1)$ & $7(2)$ & Norte da América do Sul & VU \\
\hline & $\begin{array}{l}\text { Selenidera maculirostris } \\
\text { (araçari-poca) }\end{array}$ & 5 & 17 & Argentina, Brasil, Paraguai e Bolívia & $\mathrm{LC}$ \\
\hline \multicolumn{6}{|c|}{ PSITTACIFORMES } \\
\hline \multirow[t]{2}{*}{ Cacatuidae } & $\begin{array}{l}\text { Cacatua moluccensis } \\
\text { (cacatua-das-molucas) }\end{array}$ & 1 & 15 & Indonésia & $\mathrm{VU}$ \\
\hline & $\begin{array}{l}\text { Nymphicys hollandicus } \\
\text { (calopsita) }\end{array}$ & 1 & 1 & Austrália & $\mathrm{LC}$ \\
\hline \multirow[t]{4}{*}{ Psittacidae } & $\begin{array}{l}\text { Amazona aestiva } \\
\text { (papagaio-verdadeiro) }\end{array}$ & $12(1)$ & $35(1)$ & Argentina, Bolívia e Paraguai & $\mathrm{LC}$ \\
\hline & $\begin{array}{l}\text { Amazona amazonica } \\
\text { (papagaio-do-mangue) }\end{array}$ & 2 & 2 & América do Sul & $\mathrm{LC}$ \\
\hline & $\begin{array}{l}\text { Amazona brasiliensis } \\
\text { (papagaio-de-cara-roxa) }\end{array}$ & 9 & 9 & Brasil & VU \\
\hline & $\begin{array}{l}\text { Amazona farinosa } \\
\text { (papagaio-moleiro) }\end{array}$ & 2 & 5 & América do Sul & NT \\
\hline
\end{tabular}




\begin{tabular}{|c|c|c|c|c|c|}
\hline & $\begin{array}{l}\text { Amazona festiva } \\
\text { (papagaio-da-varzea) }\end{array}$ & 6 & 6 & Brasil, Colômbia, Equador e Peru & NT \\
\hline & $\begin{array}{l}\text { Amazona ochrocephala } \\
\text { (papagaio-campeiro) }\end{array}$ & 4 & 7 & América do Sul & LC \\
\hline & $\begin{array}{l}\text { Amazona rhodocorytha } \\
\text { (chauá) }\end{array}$ & 3 & 3 & Brasil & EN \\
\hline & $\begin{array}{l}\text { Amazona sp. } \\
\text { (papagaio) }\end{array}$ & 2 & 2 & $=0$ & - \\
\hline & $\begin{array}{l}\text { Amazona vinacea } \\
\text { (papagaio-de-peito-roxo) }\end{array}$ & 3 & 6 & Argentina, Brasil e Paraguai & EN \\
\hline & $\begin{array}{l}\text { Anodorhynchus } \\
\text { hyacinthinus } \\
\text { (arara-azul-grande) }\end{array}$ & $22(2)$ & $46(2)$ & Bolívia, Brasil e Paraguai & $\mathrm{VU}$ \\
\hline & $\begin{array}{l}\text { Anodorhynchus leari } \\
\text { (arara-azul-de-lear) }\end{array}$ & 15 & 44 & Brasil & EN \\
\hline & $\begin{array}{l}\text { Ara ararauna } \\
\text { (arara-canindé) }\end{array}$ & 3 & 3 & América do Sul & $\mathrm{LC}$ \\
\hline & $\begin{array}{l}\text { Ara chloropterus } \\
\text { (arara-vermelha-grande) }\end{array}$ & 3 & 10 & América do Sul & $\mathrm{LC}$ \\
\hline & $\begin{array}{l}\text { Ara macao } \\
\text { (araracanga) }\end{array}$ & 3 & 12 & América do Sul e Central & $\mathrm{LC}$ \\
\hline & $\begin{array}{l}\text { Ara rubrogenys } \\
\text { (ararinha-de-testa- } \\
\text { vermelha) }\end{array}$ & 5 & 8 & Bolívia & EN \\
\hline & $\begin{array}{l}\text { Ara severus } \\
\text { (maracaná-guaçu) }\end{array}$ & 2 & 2 & América do Sul & $\mathrm{LC}$ \\
\hline
\end{tabular}




\begin{tabular}{|c|c|c|c|c|c|}
\hline & $\begin{array}{l}\text { Aratinga auricapillus } \\
\text { (jandaia-de-testa- } \\
\text { vermelha) }\end{array}$ & 1 & 1 & Brasil & NT \\
\hline & $\begin{array}{l}\text { Aratinga jandaya } \\
\text { (jandaia-verdadeira) }\end{array}$ & 2 & 3 & Brasil & $\mathrm{LC}$ \\
\hline & $\begin{array}{l}\text { Aratinga nenday } \\
\text { (periquito-de-cabeça- } \\
\text { preta) }\end{array}$ & 9 & 17 & Argentina, Bolívia, Brasil e Paraguai & $\mathrm{LC}$ \\
\hline & $\begin{array}{l}\text { Aratinga solstitialis } \\
\text { (jandaia-amarela) }\end{array}$ & 2 & 2 & Brasil, Guianas & EN \\
\hline & $\begin{array}{l}\text { Cyanopsitta spixii } \\
\text { (ararinha-azul) }\end{array}$ & $4(1)$ & $8(1)$ & Brasil & $\mathrm{CR}$ \\
\hline & $\begin{array}{l}\text { Deroptyus accipitrinus } \\
\text { (anacã) }\end{array}$ & 3 & 9 & América do Sul & $\mathrm{LC}$ \\
\hline & $\begin{array}{l}\text { Eos bornea } \\
\text { (papagaio-escarlate) }\end{array}$ & 2 & 5 & Indonésia & LC \\
\hline & $\begin{array}{l}\text { Eupsittula aurea } \\
\text { (periquito-rei) }\end{array}$ & 15 & 16 & $\begin{array}{l}\text { Argentina, Bolívia, Brasil, Paraguai, } \\
\text { Peru, Suriname }\end{array}$ & LC \\
\hline & $\begin{array}{l}\text { Guarouba guarouba } \\
\text { (ararajuba) }\end{array}$ & $7(1)$ & $12(1)$ & Brasil & VU \\
\hline & $\begin{array}{l}\text { Graydidascalus } \\
\text { brachyurus } \\
\text { (curica-verde) }\end{array}$ & 1 & 2 & $\begin{array}{l}\text { Brasil, Colômbia, Equador, Guiana } \\
\text { Francesa e Peru }\end{array}$ & $\mathrm{LC}$ \\
\hline & $\begin{array}{l}\text { Pionites leucogaster } \\
\text { (marianinha-de-cabeça- } \\
\text { amarela) }\end{array}$ & 6 & 6 & Brasil & EN \\
\hline
\end{tabular}




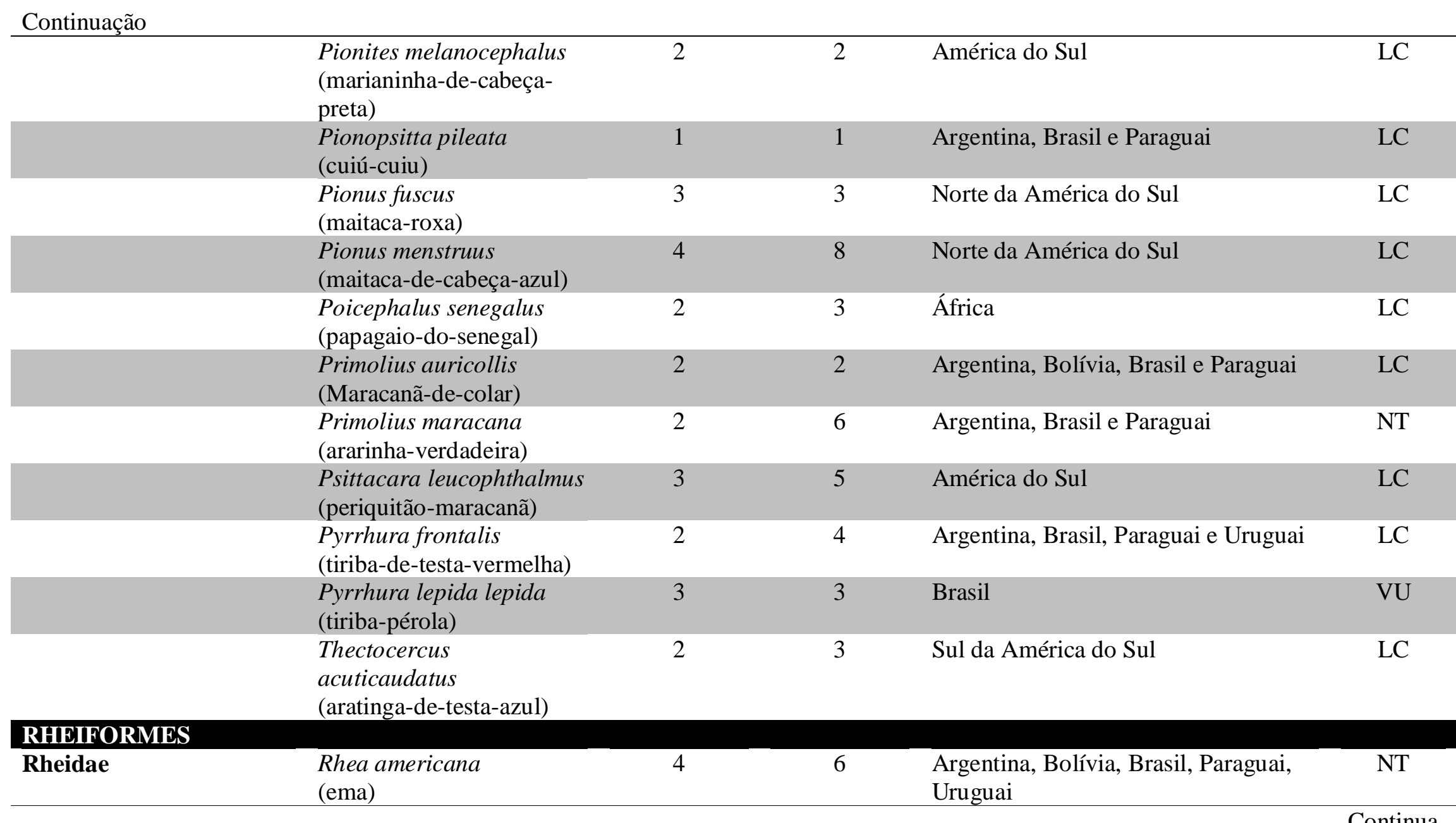


Continuação

\begin{tabular}{|c|c|c|c|c|c|}
\hline STRIGIFORM & & & & & \\
\hline Strigidae & $\begin{array}{l}\text { Asio stygius } \\
\text { (mocho-diabo) }\end{array}$ & 3 & 5 & América do Sul & $\mathrm{LC}$ \\
\hline & $\begin{array}{l}\text { Bubo virginianus } \\
\text { (jacurutu) }\end{array}$ & 1 & 2 & América do Sul e Central & LC \\
\hline & $\begin{array}{l}\text { Megascops choliba } \\
\text { (corujinha-do-mato) }\end{array}$ & 2 & 2 & América do Sul & $\mathrm{LC}$ \\
\hline & $\begin{array}{l}\text { Pseudoscops clamator } \\
\text { (coruja-orelhuda) }\end{array}$ & 2 & 18 & América do Sul e Central & $\mathrm{LC}$ \\
\hline & $\begin{array}{l}\text { Pulsatrix perspicillata } \\
\text { (murucututu) }\end{array}$ & 2 & 6 & América do Sul e Central & LC \\
\hline Tytonidae & $\begin{array}{l}\text { Tyto alba } \\
\text { (suindara) }\end{array}$ & 3 & 5 & $\begin{array}{l}\text { América do Sul e Central, Estados } \\
\text { Unidos, África, Europa, Oceania, Sul } \\
\text { da Ásia }\end{array}$ & LC \\
\hline STRUTHIONI & & & & & \\
\hline Struthionidae & $\begin{array}{l}\text { Struthio camelus } \\
\text { (avestruz) }\end{array}$ & $8(1)$ & $12(1)$ & África & $\mathrm{LC}$ \\
\hline
\end{tabular}

Status de Ameaça de acordo com a IUCN: menor preocupação (LC), quase ameaçado (NT), vulnerável (VU), ameaçado (EN), criticamente ameaçado (CR). 
APÊNDICE B- Artigo publicado no Int J Parasitol Parasites Wildl. "Plasmodium (Novyella) nucleophilum from an Egyptian Goose in São Paulo Zoo, Brazil: microscopic confirmation and molecular characterization”. Chagas et al., 2013. 
Brief Report

\title{
Plasmodium (Novyella) nucleophilum from an Egyptian Goose in São Paulo Zoo, Brazil: microscopic confirmation and molecular characterization is
}

\author{
Carolina Romeiro Fernandes Chagas ${ }^{a}$, Gediminas Valkiūnas ${ }^{b}$, Carolina Vaz Cabral Nery ${ }^{a}$, \\ Paloma Canedo Henrique a , Irys Hany Lima Gonzalez ${ }^{a}$, Eliana Ferreira Monteiro ${ }^{\text {, }}$ \\ Lilian de Oliveira Guimarães ${ }^{\mathrm{c}}$, Camila Malta Romano ${ }^{\mathrm{d}}$, Karin Kirchgatter ${ }^{\mathrm{c}, *}$ \\ a Zoological Park Foundation, São Paulo, Brazil \\ ${ }^{\mathrm{b}}$ Institute of Ecology, Nature Research Centre, Lithuania \\ ${ }^{\mathrm{c}}$ Malaria Research Center, Superintendence for Endemic Disease Control, São Paulo Institute of Tropical Medicine, University of São Paulo, Brazil \\ ${ }^{\mathrm{d}}$ Laboratory of Virology, São Paulo Institute of Tropical Medicine, University of São Paulo, Brazil
}

\section{A R T I C L E I N F O}

\section{Article history:}

Received 17 June 2013

Revised 10 September 2013

Accepted 19 September 2013

\section{Keywords:}

Alopochen aegyptiacus

Plasmodium nucleophilum

Brazil

Goose

Avian malaria diagnosis

P. (Haemamoeba) sp.

\begin{abstract}
A B S T R A C T
Plasmodium (Novyella) nucleophilum was identified using microscopy and PCR, in an Egyptian Goose (Alopochen aegyptiacus) that died in São Paulo Zoo, Brazil. This parasite is characterized by elongated gametocytes, small meronts with scant cytoplasm, less than eight merozoites and mainly for having all the stages appressed to the nuclei of infected erythrocytes. Additionally, Plasmodium (Haemamoeba) sp. was identified by microscopy in the same blood sample. The latter parasite lacks nucleophilic blood stages and is characterized by large roundish trophozoites, each with a large prominent centrally collated vacuole. This co-infection was not confirmed by PCR amplification of the mitochondrial cytochrome $b$ (cytb) gene and sequencing; only one Plasmodium sp. cytb sequence was detected in the blood sample. Since parasitemia of $P$. nucleophilum (2.4\%) was much higher than that of $P$. (Haemamoeba) sp. (0.2\%), PCR may have favored the amplification of the cytb sequence of the former. Phylogenetic analysis is in agreement with this conclusion because the reported cytb sequence was positioned in the same branch of sequences of several Novyella species. This is the first assignment of the mitochondrial cytb gene sequence to $P$. nucleophilum. The $P$. (Haemamoeba) parasite is particularly similar to Plasmodium (Haemamoeba) tejerai, because its advanced trophozoites and young erythrocytic meronts possess a large vacuole with prominent pigment granules arranged around it, the characteristic features of development in this species. For definitive identification of $P$. (Haemamoeba) species, mature meronts and gametocytes are required; however, these were absent from the thin blood smear. Representative images of the blood stages of $P$. nucleophilum and $P$. (Haemamoeba) sp. are provided. Together with microscopy data, the $P$. nucleophilum cytb sequence will assist in molecular identification (barcoding) of this Plasmodium species in other birds.
\end{abstract}

(c) 2013 The Authors. Published by Elsevier Ltd. All rights reserved.

\section{Introduction}

Haemosporidian parasites (Sporozoa: Haemosporida) are cosmopolitan protists that parasitize birds and other animals and use blood-sucking dipteran insects as vectors. More than 200 species of avian haemosporidians from hundreds of bird species have been described including over 50 morphologically distinct species of the genus Plasmodium belonging to five subgenera (Valkiūnas, 2005; Zehtindjiev et al., 2012). Brazil has one of the richest bird

\footnotetext{
This is an open-access article distributed under the terms of the Creative Commons Attribution-NonCommercial-No Derivative Works License, which permits non-commercial use, distribution, and reproduction in any medium, provided the original author and source are credited.

* Corresponding author. Tel./fax: +55 1130818039.

E-mail address: karink@usp.br (K. Kirchgatter).
}

faunas on the planet and some species of captive and wild birds have been shown to be infected with blood protists, including parasites belonging to all subgenera of Plasmodium, but only a few studies have been conducted on biology of these parasites (rev. in Braga et al., 2011).

In zoological parks, the animals live in a high density, close to animals from different zoogeographical regions, which can favor parasite infections (Primarck and Rodrigues, 2001; Silva and Corrêa, 2006). Many zoos have rich vegetation and are located in bush lands, which are visited by migrant birds every year. Infected migrant birds are potential donors of parasitic infections, which can be transmitted to zoo birds, particularly Plasmodium infections, since the relationship between the parasite and host is of low specificity (Bensch et al., 2000). Thus, studies involving parasites of migrating birds and the zoo animals that are in proximity to them are important for wildlife conservation. 
The Atlantic forest is considered as one of world's biodiversity hot spots and some of the best and most extensive examples of this biome are in São Paulo (Ribeiro et al., 2009). São Paulo Zoo, established in 1958, is located in one of the last forest remnants within the City of São Paulo, the largest city in Brazil, with a high density and diversity of mosquitoes transmitting avian malaria (Guimarães et al., 2000; Bueno et al., 2010; Ribeiro et al., 2012). The zoo is located in an area of $824,529 \mathrm{~m}^{2}$ of original Atlantic Forest with the headwaters of the historical Ipiranga stream, whose waters form a lake that receives several wild species of birds including migratory species. Around the lake, the forest shelters wild native animals, forming diverse wildlife parallel to the zoo animal collection. More than 3000 animals are on display, representing species of mammals, birds, reptiles, amphibians and invertebrates. During migration and the wintering of birds from various American countries, as well as from other Brazilian regions, the space destined for zoo animals is shared by migratory species, including opportunistic species. The latter are behaviorally flexible birds living in variable environmental conditions that are sustained by different food sources. Thus, living freely in the area of the zoo, such birds can rapidly take advantage of favorable conditions when they arise. Because blood-sucking mosquitoes that can transmit avian malaria are widespread in the zoo (Bueno et al., 2010) and favorable abiotic conditions for malaria transmission also exist, we initiated an investigation in São Paulo Zoo in order to estimate the prevalence of Plasmodium spp. in birds using both PCR-based and microscopy methods. In this paper, we report a malaria infection in an Egyptian Goose (Alopochen aegyptiacus) that was born in São Paulo Zoo and lived in one of the lakes where migratory birds are present during their migration and wintering. Two Plasmodium species were identified and a mitochondrial cytochrome $\mathrm{b}(c y t b)$ gene sequence was determined, enabling the molecular characterization of one these parasites. Illustrations of blood stages of both parasites are provided, and phylogenetic analysis identified DNA lineages closely related to them.

\section{Material and methods}

\subsection{Case history}

A 10-year-old adult male goose, born at the São Paulo Zoo, was referred to the Veterinary Division with clinical signs of incoordination, in October 2011. During clinical examination, it was apathetic, skinny, dehydrated and presented pale mucosa. The goose had a small injury in the cloacal region, wet feathers and a lot of dipteran larvae all over its body. It was physically restrained for blood sample collection, venous access to administration of fluid with glucose and antibiotics (enrofloxacin), larvae removal and cleaning and drying of the feathers. During the procedure, the goose had a cardiorespiratory arrest, reanimation was unsuccessful and it died. The blood examination indicated that it was anemic with hematocrit levels of $31 \%$ (reference values are $41-54 \%$ ). It presented severe leukocytosis, $88 \times 10^{3} \mu \mathrm{L}\left(6.39-21.73 \times 10^{3} \mu \mathrm{L}\right)$, and heterophilia, $81.84 \times 10^{3} \mu \mathrm{L}\left(2.62-13.41 \times 10^{3} \mu \mathrm{L}\right)$, indicating the presence of an infectious agent. Blood biochemistry results were abnormal: uric acid and aspartate aminotransferase (AST) were very high, $28.5 \mathrm{mg} / \mathrm{dL}(3.0-8.6 \mathrm{mg} / \mathrm{dL})$ and $385 \mathrm{UI} / \mathrm{L}(9-75 \mathrm{UI} / \mathrm{L})$, respectively. The reference values (in parenthesis) were obtained from ISIS 2002 (http://www.isis.org). During necropsy, thoracic air sac presented with a yellowish color and fungal colonies, suggesting Aspergillus sp. infection, which was confirmed by histopathology. Plasmodium sp. parasitemia, splenomegaly, a severe pulmonary edema and the presence of signs of multifocal necrosis on the liver were also observed. However, the hepatitis may have been caused by the fungal toxin released by Aspergillus sp. and could have contributed to the goose's death (Quist et al., 2007). The causa mortis was likely respiratory insufficiency.

\subsection{Collection of blood samples and representative material}

Venous blood was collected from median metatarsal vein of the goose during clinical examination for haemogram and biochemistry investigation. A thin blood smear was prepared without anticoagulant and the remaining blood was placed in a lithium heparin tube and frozen for DNA extraction. The thin blood smear was fixed by methanol, stained by Giemsa and 100 microscopic fields were examined under light microscopy $(1000 \times)$ (Valkiūnas, 2005). The intensity of parasitemia was determined, as recommended by Godfrey et al. (1987). The voucher thin blood smears from the infected goose were deposited in the Clinical Laboratory of the Zoological Park Foundation, São Paulo, Brazil (accession numbers 26679A and 26679B); digital images of the parasites are also available in the Clinical Laboratory and in the Institute of Ecology, Nature Research Centre, Vilnius, Lithuania. The sample of gDNA from the Egyptian Goose (original field number is 7885) is deposited in the Clinical Laboratory of the Zoological Park Foundation, São Paulo, Brazil.

Morphology of Plasmodium nucleophilum from the Egyptian Goose was compared with the neohapantotype preparations of the same parasite from experimentally infected domestic canary Serinus canaria domestica (R. D. Manwell's original strain, accession nos. 640, 641) in the Garnham Collection at the Natural History Museum, London.

\subsection{Goose genomic DNA ( $g D N A$ ) extraction, PCR amplification of Plasmodium sp. cytb fragments, sequencing and sequence data analysis}

After thawing, the blood sample was centrifuged and 100$150 \mu \mathrm{l}$ of red blood pellets were used for the DNA extraction. First, an initial lyse was performed with $1 \%$ saponin. Next, the pellet was washed twice in ultrapure water and submitted to the extraction protocol with the $\mathrm{GFX}^{\mathrm{TM}}$ Genomic Blood DNA Purification Kit (Amersham Biosciences, GE Healthcare), following the manufacturer's instructions. The gDNA was eluted in $100 \mu$ l of ultrapure water and stored at $-20^{\circ} \mathrm{C}$. A fragment of $1.1 \mathrm{~kb}$ (approximately $92 \%$ of the gene) from the mitochondrial cytochrome b gene (cytb) was amplified using a nested PCR, taking standard precautions to prevent cross-contamination of samples. The PCR reactions were conducted as previously described (Perkins and Schall, 2002) using primers DW2 and DW4 and $5 \mu$ of gDNA in the first reaction and $1 \mu \mathrm{l}$ aliquot of this product was used as a template for a nested reaction with primers DW1 and DW6. All these primers are specific to malarial parasites and do not amplify host DNA or that of other apicomplexan species.

The PCR product of $1 \mathrm{~kb}$ was sequenced by Big Dye Terminator v3.0 Cycle Sequencing Kit in ABI Genetic Analyzer (ABI, USA), using PCR oligonucleotides (DW1 and DW6) and internal primers DW3 and DW8 (Perkins and Schall, 2002). The sequence obtained was aligned using BLASTN (Basic Local Alignment Search Tool) with sequences from the GenBank available at http://www.ncbi.nlm.nih.gov/blast/Blast.cgi (Altschul et al., 1997) and MalAvi available at http://mbio-serv2.mbioekol.lu.se/Malavi/ blast.html (Zhang et al., 2000). The P. nucleophilum sequence was deposited in the GenBank database with accession number JX467689.

\subsection{Phylogenetic analysis}

The phylogenetic relationship of the $P$. nucleophilum lineage from the Egyptian Goose and other Plasmodium species described 
in birds was inferred using cytb gene sequences. The sequences were selected from the MalAvi database, a public database of malaria parasites and related haemosporidians in avian hosts (Bensch et al., 2009). The phylogenetic tree was constructed using the Bayesian inference method implemented in MrBayes v3.2.0 (Huelsenbeck and Ronquist, 2001). Bayesian inference was performed with two Markov Chain Monte Carlo searches of 3 million generations each with sampling of 1 in 300 trees. After a burn-in of $25 \%$, the remaining 15,002 trees were used to calculate the $50 \%$ majority-rule consensus tree.

\section{Results and discussion}

Co-infection of P. (Novyella) nucleophilum Manwell, 1935 (Fig. 1a-f) and Plasmodium (Haemamoeba) sp. (Fig. 1g-i) was detected by microscopy. The intensity of parasitemia of these parasites was $2.4 \%$ and $0.2 \%$, respectively. These two species can be readily distinguished from each other due to the presence or absence of nucleophilic parasites and of large roundish trophozoites. $P$. nucleophilum is characterized by (i) small (less than erythrocyte nuclei) meronts with scanty cytoplasm; (ii) $\leqslant 8$ merozoites in meronts; (iii) small (length $<10 \mu \mathrm{m}$ on average) elongated gametocytes possessing $<10$ pigment granules; (iv) the presence of vacuoles and refractive globules in some trophozoites and meronts; (v) trophozoites, meronts and gametocytes appressed to erythrocyte nuclei (nucleophilic feature) (Fig. 1a-f). The parasites observed in the Egyptian Goose were similar to the blood stages present in the type material of $P$. nucleophilum. However, (i) small vacuoles were frequently observed in trophozoites and meronts in the blood of the goose, and (ii) refractive globules were observed in many erythrocytic meronts. These feature are also visible in the type material of $P$. nucleophilum, but were observed less frequently; this could be a peculiarity of the parasite development in the goose. In contrast, the second species identified, $P$. (Haemamoeba) sp., lacks nucleophilic blood stages and is characterized by large roundish trophozoites, each with a prominent centrally collated vacuole (Fig. 1g-i). Because large trophozoites (size close to erythrocyte nuclei), which displace the erythrocyte nuclei were present, this parasite belongs to the subgenus Haemamoeba (Fig. 1g). For definitive identification of $P$. (Haemamoeba) species, mature meronts and gametocytes are required; however, these blood stages were absent from the thin blood film.

$P$. (Novyella) nucleophilum has been recorded in all zoogeographical regions, except the Australian and Antarctic, but is particularly frequently reported in the Americas. This parasite is particularly common in birds belonging to the Passeriformes, but has also been identified in species of Anseriformes, Columbiformes and Piciformes. Originally, P. nucleophilum was discovered in North America and has subsequently been reported in many bird species in South America (Manwell, 1935; Garnham, 1966). A sub-species, $P$. nucleophilum toucani, has been reported in Brazil in the Chestnut-mandibled Toucan (Piciformes), but its distribution has been insufficiently investigated (Manwell and Sessler, 1971). It is worth mentioning that Lucena (1939) identified P. nucleophilum in house sparrows (Passer domesticus) examined in Sao Paulo. It is probable that this bird serves as a natural reservoir host of $P$. nucleophilummalaria infection, a fact that warrants further investigation. Blood stages of the reported parasite are morphologically similar to previous descriptions (Manwell, 1935; Valkiūnas, 2005), so their detailed morphological description was not provided. Virulence of $P$. nucleophilum varies markedly. Certain subspecies are relatively benign in experimentally infected canaries, but can be highly virulent in experimentally infected ducklings, and are fatal in many cases (Valkiūnas, 2005).

The Haemamoeba subgenus contains 11 malaria parasite species, and $P$. relictum, the type species, has been reported from São
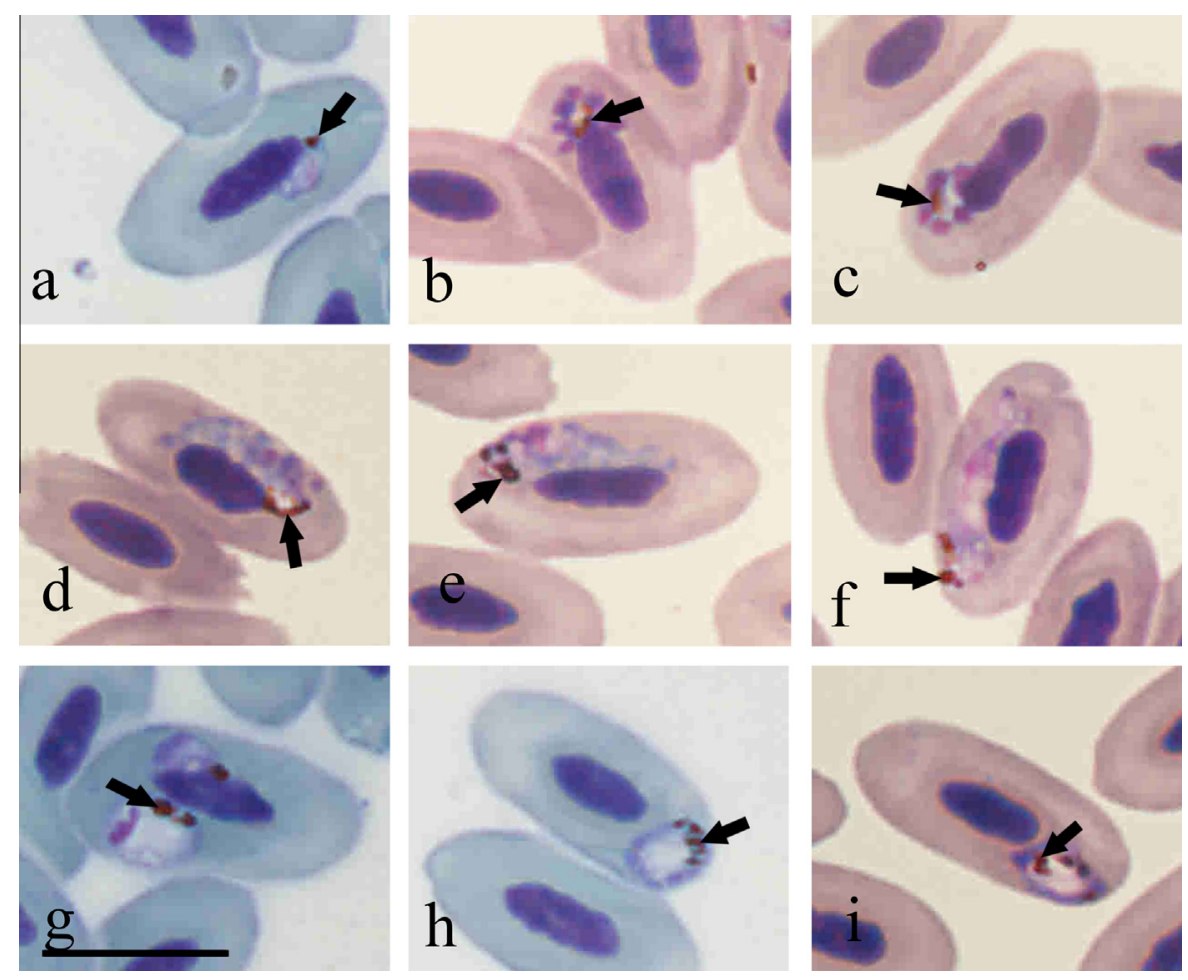

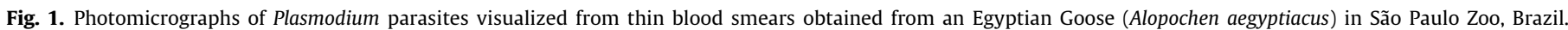

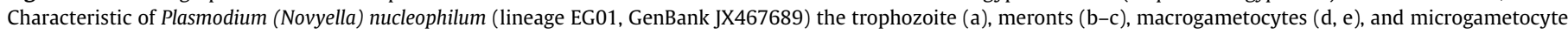

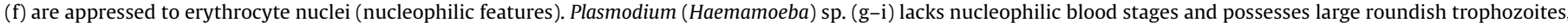

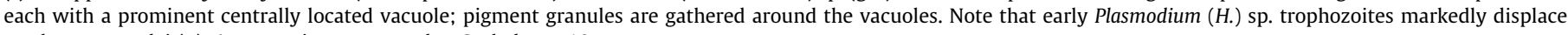
erythrocyte nuclei (g). Arrows, pigment granules. Scale bar $=10 \mu \mathrm{m}$. 
Table 1

Avian hosts and countries where the DENPET03 lineage of Plasmodium nucleophilum has been reported.

\begin{tabular}{|c|c|c|c|c|}
\hline Order & Family & Species & Reference & Country \\
\hline \multirow{12}{*}{ Passeriformes } & & Basileuterus culicivorus & Durrant et al. (2006) & Uruguay \\
\hline & & Basileuterus leucoblepharus & Durrant et al. (2006) & Uruguay \\
\hline & & Cacicus cela & Durrant et al. (2006) & Guyana \\
\hline & & Cacicus haemorrhous & Durrant et al. (2006) & Guyana \\
\hline & & Cranioleuca pyrrhophia & Durrant et al. (2006) & Uruguay \\
\hline & Fringillidae & Geothlypis trichas & Pagenkopp et al. (2008) & USA \\
\hline & & Gnorimopsar chopi & Durrant et al. (2006) & Uruguay \\
\hline & & Setophaga petechia & Szymanski and Lovette (2005) & USA \\
\hline & & Volatinia jacarina & Durrant et al. (2006) & Guyana \\
\hline & & Zonotrichia capensis & Durrant et al. (2006) & Uruguay \\
\hline & Passeridae & Passer domesticus & Marzal et al. (2011) & Brazil $^{\mathrm{a}}$ \\
\hline & Vireonidae & Vireo griseus & Ricklefs and Fallon (2002) & USA \\
\hline Psittaciformes & Psittacidae & Diopsittaca nobilis & Durrant et al. (2006) & Guyana \\
\hline
\end{tabular}

a Midwest and North.

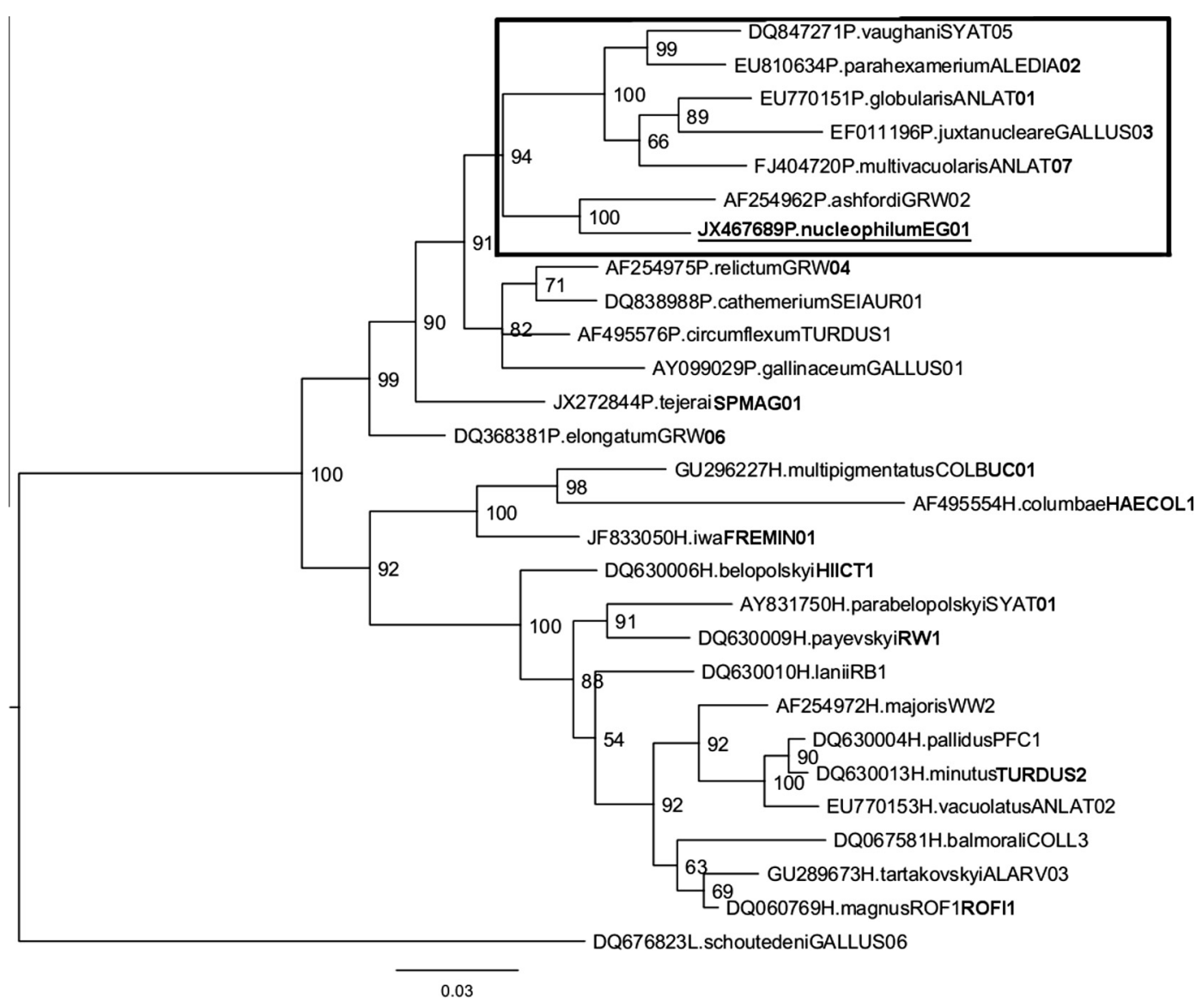

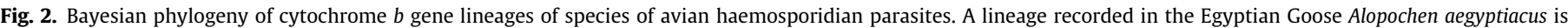

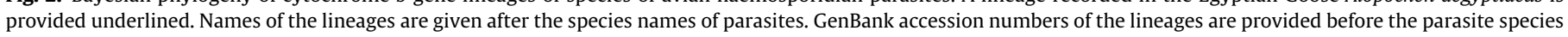
names. Nodal support values (in percentage) indicate posterior clade probabilities. Plasmodium species from Novyella subgenus are boxed.

Paulo Zoo (Bueno et al., 2010). However, the P. (Haemamoeba) parasite recorded in this study is more similar to Plasmodium (Haemamoeba) tejerai because each of its advanced trophozoites and young erythrocytic meronts possessed a large vacuole with pigment granules arranged around it, the characteristic features of this species. Other described P. (Haemamoeba) parasites do not possess these characters (Valkiūnas, 2005). Plasmodium tejerai was first recorded in domestic turkey, Meleagris gallopavo, in Venezuela and some experimentally infected birds, including several Anatidae species (Gabaldon and Ulloa, 1977). Recently, it was identified in penguins from a rehabilitation centre in South Brazil
(Silveira et al., 2013). It is the only Plasmodium parasite with large vacuoles and pigment granules arranged around the vacuoles in trophozoites (Fig. 1g-i) found in South America (Gabaldon and Ulloa, 1977). Because mature meronts and gametocytes of $P$. (Haemamoeba) sp. were absent from our blood sample and we were unable to detect sequence data, the definitive identification of the parasite is currently impossible.

The PCR protocol did not confirm co-infection and amplify only one cytb sequence, since no "double bases" were present in electropherograms. Previous studies have demonstrated that mixed infections are not efficiently detected using general primers (Valkiūnas 
et al., 2006; Martínez et al., 2009). Moreover, Plasmodium spp. detection depends on the parasite lineage composition during coinfections and the intensity of the infections. For haemosporidians, the PCR assays currently used can underestimate the occurrence of co-infections in the majority of natural infections (Valkiūnas et al, 2008a). In a recent study that used a PCR methodology to detect haemosporidians in 214 Brazilian birds, $14 \%$ of Plasmodium spp. infections were verified, but no co-infections were observed (Marzal et al., 2011). Failure to amplify the cytb gene of Plasmodium polymorphum in a mixed infection with $P$. relictum, even with a significantly greater parasitemia in the former, has also been demonstrated (Zehtindjiev et al., 2012). Thus, the combination of microscopy and PCR-based tools is essential for correct identification of Plasmodium spp. and investigation of the biodiversity of haemosporidian parasites in wildlife.

The sequence obtained (GenBank \#JX467689, 1122 bp) was compared by BLASTN with GenBank and MalAvi sequences. In the GenBank database, the most similar Plasmodium sequences were GQ395660 and GQ141580 (both from Plasmodium sp.) with $97 \%$ identity (1006 of $1036 \mathrm{bp}$ ). The most similar sequence with species identification was a sequence from $P$. ashfordi (\#AF254962) belonging to the subgenus Novyella, with $94 \%$ identity ( 451 of $478 \mathrm{bp}$ ). This sequence was formerly incorrectly attributed to $P$. nucleophilum (see review in Valkiūnas et al., 2007). In the GenBank, the presence of this and other misidentified sequences of avian haemosporidians has been proven (Valkiūnas et al., 2008b). The great majority of blood stages of $P$. ashfordi are non-nucleophilic, thus it can be readily distinguished from $P$. nucleophilum (Fig. 1).

In the MalAvi database, which comprises 1323 sequences and 590,601 total base pairs, we identified a sequence (AY640137), DENPET03 lineage of $P$. nucleophilum, with $100 \%$ identity in 479 bp (nucleotides 235-713 from our sequence). This sequence has been reported in 13 avian hosts belonging to 11 genera, 5 families and 2 orders (including passerines) in North and South America (Table 1). This is in agreement with previous microscopic studies (Garnham, 1966; Valkiūnas, 2005) and demonstrates that $P$. nucleophilum is likely a host generalist, as has been demonstrated for many other avian Plasmodium species (Szymanski and Lovette, 2005; Palinauskas et al., 2007). However, in the MalAvi database, there is no record of occurrence of any haemosporidian parasites in the Egyptian goose (http://mbio-serv2.mbioekol.lu.se/Malavi/index.html).

The phylogenetic analysis is in agreement with our morphological identification since the reported cytb sequence clustered with sequences of several Novyella species, forming a well-supported clade with high posterior probability (Fig. 2). This record was included in the MalAvi database as EG01 (acronym of Egyptian goose lineage 1).

Although in most organisms the gene of choice for barcoding is cytochrome oxidase subunit I (COI), a $479 \mathrm{bp}$ fragment of the $c y t b$ gene has been successfully used as a barcode of avian haemosporidian species (Bensch et al., 2009). This study provides the first assignment of a mitochondrial cytb gene sequence to $P$. nucleophilum deposited in the GenBank and can be used for molecular identification (barcoding) of this infection in other birds. The same sequence has been reported in numerous bird species in the Americas (Table 1). The identification of barcodes to recognize avian haemosporidians species is an important step, since morphological identification of these parasites requires extensive taxonomic experience and is not always possible due to predominance of light parasitemias in wildlife (Hajibabaei et al., 2007). Currently, there are few experts with such knowledge and few people in the next generation of scientists are learning these taxonomic skills (Valkiūnas et al., 2008b); thus, the development of barcodes to identify avian malaria and related parasites is an urgent task.

\section{Acknowledgments}

The authors are grateful to the staff of the São Paulo Zoological Park Foundation (Fundação Parque Zoológico de São Paulo) for their support during this study. The authors would also like to thank Dr. A. Warren of the Natural History Museum, London, UK, for providing the neotype material of $P$. nucleophilum. This research was funded by FAPESP (2012/51427-1) to KK. All procedures were approved by the Ethical Principles in Animal Research, of the Ethics Committee of Institute of Tropical Medicine, University of São Paulo (CPE-IMT/193), and were in full compliance with federal permits issued by the Brazilian Ministry of the Environment (SISBIO \# 34605-2).

\section{References}

Altschul, S.F., Madden, T.L., Schaffer, A.A., Zhang, J., Zhang, Z., Miller, W., Lipman, D.J., 1997. Gapped BLAST and PSIBLAST: a new generation of protein database search programs. Nucleic Acids Res. 25, 3389-3402.

Bensch, S., Stjernman, M., Hasselquist, D., Östman, Ö., Hansson, B., Westerdahl, H., Pinheiro, R.T., 2000. Host specificity in avian blood parasites: a study of Plasmodium and Haemoproteus mitochondrial DNA amplified from birds. Proc. Biol. Sci. 267, 1583-1589.

Bensch, S., Hellgren, O., Pérez-Tris, J., 2009. MalAvi: a public database of malaria parasites and related haemosporidians in avian hosts based on mitochondrial cytochrome b lineages. Mol. Ecol. Resour. 9, 1353-1358.

Braga, E.M., Silveira, P., Belo, N.O., Valkiūnas, G., 2011. Recent advances in the study of avian malaria: an overview with an emphasis on the distribution of Plasmodium spp. in Brazil. Mem. Inst. Oswaldo Cruz. 106 (Suppl. I), 3-11.

Bueno, M.G., Lopez, R.P.G., Menezes, R.M.T., Costa-Nascimento, M.J., Lima, G.F.M.C., Araújo, R.A.S., Guida, F.J.V., Kirchgatter, K., 2010. Identification of Plasmodium relictum causing mortality in penguins (Spheniscus magellanicus) from Sao Paulo Zoo. Brazil. Vet. Parasitol. 173, 123-127.

Durrant, K.L., Beadell, J.S., Ishtiaq, F., Graves, G.R., Olson, S.L., Gering, E., Peirce, M.A. Milensky, C.M., Schmidt, B.K., Gebhard, C., Fleischer, R.C., 2006. Avian haematozoa in South America: a comparison of temperate and tropical zones. Ornithol. Monogr. 60, 98-111.

Gabaldon, A., Ulloa, G., 1977. Plasmodium (Haemamoeba) tejerai sp. n. en pavo domestico (Melleagris gallopavo) del Venezuela. Bol. Dir. Malariol. Saneam. Ambient. 17, 255-273.

Garnham, P.C.C., 1966. Malaria Parasites and Other Haemosporidia. Blackwell Scientific Publications, Oxford, p. 1114.

Godfrey, R.D., Fedynich, A.M., Pence, D.B., 1987. Quantification of hematozoa in blood smears. J. Wildl. Dis. 23, 558-565.

Guimarães, A.E., Mello, R.P., Lopes, C.M., Gentile, C., 2000. Ecology of mosquitoes (Diptera: culicidae) in areas of Serra do Mar State Park, State of São Paulo, Brazil. I - monthly frequency and climatic factors. Mem. Inst. Oswaldo Cruz 95, 1-16.

Hajibabaei, M., Singer, G.A., Hebert, P.D., Hickey, D.A., 2007. DNA barcoding: how it complements taxonomy, molecular phylogenetics and population genetics. Trends Genet. 23, 167-172.

Huelsenbeck, J.P., Ronquist, F., 2001. MRBAYES: Bayesian inference of phylogeny Bioinformatics 17, 754-755.

Lucena, D.T., 1939. Malaria aviaria: subsidios para sua sistematica e transmissão. Officinas graphicos do Jornal do Commercio, Recife, p. 126.

Manwell, R.D., 1935. How many species of avian malaria parasites are there? Am. J. Trop. Med. 15, 265-283.

Manwell, R.D., Sessler, G.J., 1971. Malaria parasites of toucans. J. Protozool. 18, 570574.

Martínez, J., Martínez-De La Puente, J., Herrero, J., Del Cerro, S., Lobato, E., Rivero-De Aguilar, J., Vásquez, R.A., Merino, S., 2009. A restriction site to differentiate Plasmodium and Haemoproteus infections in birds: on the inefficiency of general primers for detection of mixed infections. Parasitology 136, 713-722.

Marzal, A., Ricklefs, R.E., Valkiūnas, G., Albayrak, T., Arriero, E., Bonneaud, C., Czirják, G.A., Ewen, J., Hellgren, O., Hořáková, D., Iezhova, T.A., Jensen, H. Križanauskienè, A., Lima, M.R., de Lope, F., Magnussen, E., Martin, L.B., Møller, A.P., Palinauskas, V., Pap, P.L., Pérez-Tris, J., Sehgal, R.N., Soler, M., Szöllosi, E., Westerdahl, H., Zetindjiev, P., Bensch, S., 2011. Diversity, loss, and gain of malaria parasites in a globally invasive bird. PLoS One 6, e21905.

Pagenkopp, K., Klicka, J., Durrant, K., Garvin, J., Fleischer, R., 2008. Geographic variation in malarial parasite lineages in the common yellow throat (Geothlypis trichas). Conserv. Genet. 9, 1577-1588.

Palinauskas, V., Kosarev, V., Shapoval, A., Bensch, S., Valkiūnas, G., 2007. Comparison of mitochondrial cytochrome b lineages and morphospecies of two avian malaria parasites of the subgenera Haemamoeba and Giovannolaid (Haemosporida: Plasmodiidae). Zootaxa 1626, 39-50.

Perkins, S.L., Schall, J.J., 2002. A molecular phylogeny of malarial parasites recovered from cytochrome b gene sequences. J. Parasitol. 88, 972-978.

Primarck, B.R., Rodrigues, E., 2001. Biologia da Conservação. Planta, Londrina, p. 328.

Quist, C.F., Cornish, T., Wyatt, R.D., 2007. Mycotoxicosis. In: Thomas, N.J., Hunter, D.B., Atkinson, C.T. (Eds.), Infectious Diseases of Wild Birds, Blackwell Publishing, Oxford, pp. 417-430. 
Ribeiro, M.C., Metzger, J.P., Martensen, A.C., Ponzoni, F.J., Hirota, M.M., 2009. The Brazilian Atlantic Forest: How much is left, and how is the remaining forest distributed? Implications for conservation. Biol. Conserv. 142, 1141-1153.

Ribeiro, A.F., Urbinatti, P.R., de Castro Duarte, A.M., de Paula, M.B., Pereira, D.M., Mucci, L.F. Fernandes, A., de Mello, M.H. de Matos Júnior, M.O., de Oliveira, R.C. Natal, D., dos Santos Malafronte, R., 2012. Mosquitoes in degraded and preserved areas of the Atlantic Forest and potential for vector-borne disease risk in the municipality of São Paulo. Brazil. J. Vector Ecol. 37, 316-324.

Ricklefs, R.E., Fallon, S.M., 2002. Diversification and host switching in avian malaria parasites. Proc. Biol. Sci. 269, 885-892.

Silva, J.C.R., Corrêa, S.H.R., 2006. Manejo Sanitário e Biosseguridade. In: Cubas, Z.S., Silva, J.C.R., Catão-Dias, J.L. (Eds.), Tratado de Animais Selvagens - Medicina Veterinária, Roca, São Paulo, pp. 1226-1244.

Silveira, P., Belo, N.O., Lacorte, G.A., Kolesnikovas, C.K., Vanstreels, R.E., Steindel, M. Catão-Dias, J.L., Valkiūnas, G., Braga, E.M., 2013. Parasitological and new molecular-phylogenetic characterization of the malaria parasite Plasmodium tejerai in South American penguins. Parasitol. Int. 62, 165-171.

Szymanski, M.M., Lovette, I.J., 2005. High lineage diversity and host sharing of malarial parasites in a local avian assemblage. J. Parasitol. 91, 768-774.

Valkiūnas, G., 2005. Avian Malaria Parasites and Other Haemosporidia. CRC Press, New York, p. 935.
Valkiūnas, G., Bensch, S., Iezhova, T.A., Krizanauskiene, A., Hellgren, O., Bolshakov, C., 2006. Nested cytochrome $b$ polymerase chain reaction diagnostics underestimate mixed infections of avian blood haemosporidian parasites: microscopy is still essential. J. Parasitol. 92, 418-422.

Valkiūnas, G., Zehtindjiev, P., Hellgren, O., Ilieva, M., Iezhova, T.A., Bensch, S., 2007. Linkage between mitochondrial cytochrome $b$ lineages and morphospecies of two avian malaria parasites, with a description of Plasmodium (Novyella) ashfordi sp. nov. Parasitol. Res. 100, 1311-1322.

Valkiūnas, G., Iezhova, T.A., Krizanauskiene, A., Palinauskas, V., Sehgal, R.N.M., Bensch, S., 2008a. A comparative analysis of microscopy and PCR-based detection methods for blood parasites. J. Parasitol. 94, 1395-1401.

Valkiūnas, G. Atkinson, C.T., Bensch, S., Sehgal, R.N., Ricklefs, R.E., 2008b. Parasite misidentifications in genbank: how to minimize their number? Trends Parasitol. 24, 247-248.

Zehtindjiev, P., Krizanauskiene, A., Bensch, S., Palinauskas, V., Asghar, M., Dimitrov, D., Scebba, S., Valkiūnas, G., 2012. A new morphologically distinct avian malaria parasite that fails detection by established polymerase chain reaction-based protocols for amplification of the cytochrome b gene. J. Parasitol. 98, 657-665.

Zhang, Z, Schwartz, S., Wagner, L., Miller, W., 2000. A greedy algorithm for aligning DNA sequences. J. Comput. Biol. 7, 203-214. 
APÊNDICE C - Artigo publicado no Parasitol Res. "Hemosporidian parasites of free-living birds in the São Paulo Zoo, Brazil". Chagas et al., 2016. 


\title{
Hemosporidian parasites of free-living birds in the São Paulo Zoo, Brazil
}

\author{
Carolina Romeiro Fernandes Chagas ${ }^{1}$ - Lilian de Oliveira Guimarães ${ }^{2}$. \\ Eliana Ferreira Monteiro ${ }^{2}$ • Gediminas Valkiūnas ${ }^{3}$ - Michele Viana Katayama ${ }^{4}$. \\ Stéfanie Vanessa Santos ${ }^{5}$ - Fernanda Junqueira Vaz Guida ${ }^{1} \cdot$ Roseli França Simões $^{2}$. \\ Karin Kirchgatter ${ }^{2}$
}

Received: 2 December 2015 / Accepted: 7 December 2015 /Published online: 17 December 2015

(C) Springer-Verlag Berlin Heidelberg 2015

\begin{abstract}
Numerous studies addressed the diversity of bird Plasmodium and Haemoproteus parasites. However, a few have been carried out in continental avian hotspot regions such as Brazil, a country with markedly different biomes, including Amazon, Brazilian Savanna, Atlantic Forest, Caatinga, Pantanal, and Pampas. We present the first study on hemosporidian (Haemosporida) parasites in free-living birds from an Atlantic Forest fragment where more than 80 avian species have been reported. Within this area, the São Paulo Zoo locates, and it is the fourth largest zoo in the world and the largest in Latin America. A total of 133 free-living bird samples representing 12 species were collected in the zoo, with the overall hemosporidian prevalence of $18 \%$ by PCRbased diagnostics. Twenty-four positive PCR signals were reported from four different bird species, including migratory ones. Columba livia, an urban species, considered nowadays a pest in big cities, showed $100 \%$ prevalence of Haemoproteus spp., mainly Haemoproteus columbae. We discuss the
\end{abstract}

Karin Kirchgatter

karink@usp.br

1 São Paulo Zoological Park Foundation, Av. Miguel Estéfano 4241, São Paulo, SP 04301-905, Brazil

2 Malaria Research Center, Superintendence for Endemic Disease Control, São Paulo Institute of Tropical Medicine, University of São Paulo, Av. Dr. Enéas de Carvalho Aguiar 470, São Paulo, SP 05403-000, Brazil

3 Nature Research Centre, Akademijos 2, Vilnius 08412, Lithuania

4 Post-Graduate Program of Ecology and Natural Resources, Department of Ecology and Evolutionary Biology, Federal University of São Carlos, Rodovia Washington Luis km 235, São Carlos, SP 13565-905, Brazil

5 Post-Graduate Program of Infectology, Federal University of São Paulo, Rua Sena Madureira 1500, São Paulo, SP 04021-001, Brazil epidemiological importance of new parasites introduced by migratory birds in the São Paulo Zoo area and the risk it poses to the captive species, which are natives or exotics. We also warn about the influence these parasites can have on the biodiversity and the structure of host populations by altering the competitive interaction between the free-living and the captive birds.

Keywords Plasmodium - Haemoproteus · Free-living birds · Atlantic Forest · São Paulo Zoo

\section{Introduction}

Avian hemosporidians (Sporozoa, Haemosporida) are protozoan parasites with over 250 species of the genera Plasmodium, Haemoproteus, Leucocytozoon, and Fallisia, which are described in birds. They are transmitted exclusively by dipteran blood-sucking insects (Garnham 1966; Atkinson et al. 2008; Valkiūnas 2005). Although these parasites are cosmopolitan in distribution, a review of global diversity of Plasmodium and Haemoproteus genetic lineages has shown a substantial geographical bias in studies on continental avian non-hotspot regions in Europe and North America whose focus has been mainly on the Passeriformes species (Clark et al. 2014).

Brazil hosts one of the greatest diversities of fauna and flora in the world, consisting of markedly different biomes (Amazon, Cerrado, Atlantic Forest, Caatinga, Pantanal, and Pampas) and is also considered a hotspot for avian richness (Orme et al. 2005). However, more specifically for the Atlantic Forest, a few studies on the prevalence of blood parasites in birds have been conducted (Ribeiro et al. 2005; Belo et al. 2009; Sebaio et al. 2012; Lacorte et al. 2013; Motta et al. 2013). São Paulo 
is the second Brazilian state to hold large remaining areas of Atlantic forest (http://mapas.sosma.org.br/dados/) that is one of world's biodiversity hotspots (Ribeiro et al. 2009). In the county of São Paulo, the state's capital, there is an area of $26,664 \mathrm{~km}^{2}$ of forest that includes a state park named "Fontes do Ipiranga" (Parque Estadual das Fontes do Ipiranga-PEFI), where over 80 avian species have been reported. Within the PEFI, the São Paulo Zoo locates. This is the fourth largest zoo in the world and the largest in Latin America. This area has a high density and diversity of mosquitoes that can transmit avian malaria (Bueno et al. 2010), and Plasmodium (Novyella) nucleophilum has been identified and characterized molecularly from a captive goose born at the Zoo (Chagas et al. 2013). Biting midges (Ceratopogonidae) and hippoboscid flies (Hippoboscidae), which are vectors of avian Haemoproteus species, have also been reported in the São Paulo State (Felippe-Bauer and Oliveira 2001; Arzua and Valim 2010). In this paper, we present results of the first study on hemosporidian parasites in free-living birds from this area. We also discuss the effects of new parasites introduced by migratory birds to the São Paulo Zoo area and the possible risk of such introduction to the exotic captive bird species.

\section{Materials and methods}

\section{Study area}

Established in 1958, the São Paulo Zoo is located in an area of $824,529 \mathrm{~m}^{2}$ within one of the last Atlantic Forest remnants within the City of São Paulo, the largest city in Brazil (Fig. 1a). The waters of the Ipiranga stream form a lake that receives several wild species of birds including migratory species (Fig. 1b). Around the lake, the forest shelters wild native animals, forming a diverse wildlife along with the zoo animal collection where more than 3000 animals are on display, representing species of mammals, birds, reptiles, amphibians, and invertebrates. During migration and the wintering of birds from various American countries, as well as from other Brazilian regions, the space destined for zoo animals is shared by migratory species, native and opportunistic species. The latter are behaviorally flexible birds living in variable environmental conditions and sustaining from different food sources.

\section{Collection of blood samples}

Samples of different bird species were collected between September 2012 and June 2015. Healthy individual samples were collected primarily for other projects: blood from Dendrocygna viduata was collected for a research project

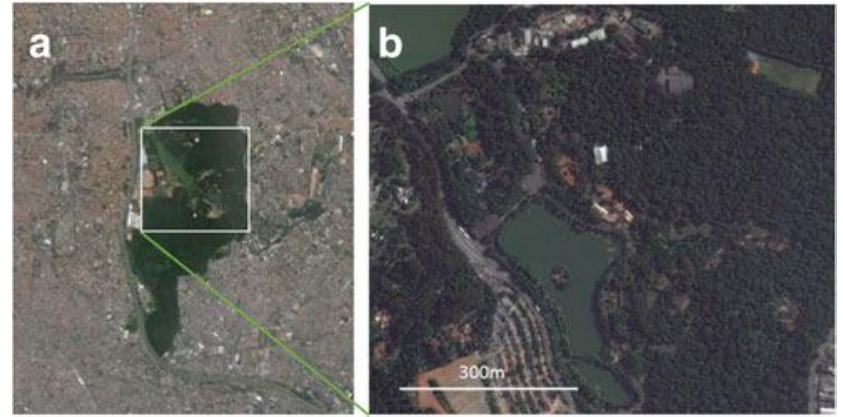

Fig. 1 Satellite images of the Atlantic forest fragment within the city of São Paulo (a) and the São Paulo Zoo within this fragment (b). Google Earth

aiming isolation of microorganisms and bacterial and fungal resistance genes in migrating birds (SISBIO 35166-2); blood from Penelope superciliaris was collected for the study of the biology of Penelope sp. (Galliformes: Cracidae) and its ecological importance in the PEFI (SISBIO 41010-1). All other samples were collected for routine activities of the veterinary staff in the park since the birds presented clinical signs of diseases (SISBIO 34605-2).

For capturing Penelope sp., a trap of wooden structure measuring $80.0 \times 80.0 \times 6.0 \mathrm{~cm}$ as a base and covered with mesh braided line fishing net of $1.0 \times 1.0 \mathrm{~cm}$ was installed on the ground in the most suitable locations in order to minimize stress and injuries to the birds. To attract birds to the trap, cracked corn was used as bait. For capturing the Anatidae species, three traps of $3.0 \times 2.4 \times 0.3 \mathrm{~m}$ were placed on the lake border. These traps were built of wood and fence with doors in the upper side to facilitate the birds' removal. To attract the birds, we use the same methodology as for catching Penelope sp., but rice and Anatidae species food were added to bait, as established by CEMAVE/IBAMA (1994). The sampled birds were ringed after identification and blood sampling; CEMAVE's model rings were used.

\section{Blood sampling and microscopic examination}

After being caught, the birds were physically restrained and the venous blood was collected. A thin blood smear was prepared without anticoagulant and the remaining blood was placed in a lithium heparin tube and frozen for DNA extraction. The thin blood smear was fixed by $100 \%$ methanol, stained by Giemsa in a work solution prepared with buffered water ( $10 \%$ stain stock solution was used), and then examined microscopically for 20-25 min: 100 fields were examined at low magnification $(\times 400)$ and 100 fields were viewed at high magnification $(\times 1000)$ (Valkiūnas 2005) using an Olympus BX41 light microscope. The intensity of parasitemia was determined by actual counting of the number of parasites per 1000 erythrocytes, as recommended by Godfrey et al. (1987). 


\section{Genomic DNA (gDNA) extraction, PCR amplification of Haemoproteus sp. and Plasmodium sp. cytb fragments, sequencing, and the sequence data analysis}

DNA from blood samples was extracted with the Wizard ${ }^{\circledR} \mathrm{SV}$ 96 Genomic DNA Purification System (Promega) with the following modifications. First, $10 \mu \mathrm{l}$ of red blood cell pellets was completed to $200 \mu \mathrm{l}$ with ultrapure water and an initial lysis was performed with Proteinase K $(0.8 \mathrm{mg} / 200 \mu \mathrm{l} \mathrm{sam}-$ ple) for $1 \mathrm{~h}$ at $37^{\circ} \mathrm{C}$. Next, $400 \mu \mathrm{l}$ of Whole Blood Lysis Buffer (Wizard ${ }^{\circledR}$ SV Lysis Buffer with $10 \%$ Triton X-100) was added and incubated overnight at room temperature. The lysates were transferred into the columns and washed according the manufacturer's instructions. The gDNA was eluted in $100 \mu \mathrm{l}$ of Nuclease-Free Water and stored at $-20^{\circ} \mathrm{C}$. The PCR reactions were conducted using a nested polymerase chain reaction targeting the mitochondrial cytochrome $b(c y t b)$ gene of Haemoproteus and Plasmodium (Hellgren et al. 2004). Primers HaemNFI and HaemNR3 and 50 ng gDNA were used in the first reaction and $1-\mu l$ aliquot of this product was used as a template for a nested reaction with primers HaemF and HaemR2. Two blood samples with different parasitemias $(<0.01$ and $6.49 \%)$ of Plasmodium sp. were used as positive control, and ultrapure water was used as a negative control. The PCR product was sequenced by Big Dye Terminator v3.0 Cycle Sequencing Kit in ABI Genetic Analyzer (ABI, USA), using PCR oligonucleotides (HaemF and HaemR2). The sequences of $\sim 480 \mathrm{bp}$ were obtained and used in this study. Sequences possessing at least one different nucleotide were considered unique lineages. In order to determine already available lineage names, the obtained sequences were aligned with sequences deposited in MalAvi database (available at http://mbio-serv2.mbioekol.lu.se/Malavi/blast.html, see Bensch et al. 2009) using BLASTN (Basic Local Alignment Search Tool, see Altschul et al. 1997). Those absent from the MalAvi database were considered as new and were named according to the MalAvi nomenclature (Bensch et al. 2009) and deposited in GenBank.

\section{Phylogenetic analysis}

The phylogenetic relationship among reported parasites was inferred using cytb gene sequences. The phylogenetic reconstruction was performed separately for Haemoproteus and Plasmodium lineages, with 24 sequences used in each analysis. The phylogenetic tree was constructed using the Bayesian inference method implemented in MrBayes v3.2.0 (Huelsenbeck and Ronquist 2001). Bayesian inference was performed with two Markov Chain Monte Carlo searches of 3 million generations, each with sampling of 1 in 300 trees. After a burn-in of $25 \%$, the remaining 15,002 trees were used to calculate the $50 \%$ majority-rule consensus tree. The phylogeny was visualized using FigTree version 1.4.0 available at http://tree.bio.ed.ac.uk/software/figtree/ (Rambaut 2006).

\section{Results}

In total, 133 samples belonging to 124 birds from 12 species were collected and screened for Plasmodium or Haemoproteus infections (Table 1). We detected an overall prevalence of $18 \%$ (24 positive samples) by PCR-based diagnostics. These positive results were found in four different bird species (Table 1), but the prevalence varied significantly among these hosts. Columba livia had highest prevalence (100\%), while other eight sampled bird species were not infected. Of these PCR positive samples, 21 samples were also positive by microscopic examination: one was positive for Plasmodium sp., with a light parasitemia, and 20 samples positive for Haemoproteus, with parasitemias ranging between 0.3 and $15.5 \%$. No co-infection with hemosporidians belonging to the same or different genera was detected by microscopy. Haemoproteus (Haemoproteus) columbae (Fig. 2) was the only species of hemosporidian parasites morphologically identified. For the first time, we provided morphological support for molecular characterization of several lineages of this parasite (Figs. 2 and 3). Although Plasmodium sp. was seen, the parasites were not identified to species level because of light parasitemia.

The $c y t b$ sequences recovered from the PCR-positive samples showed four birds positive for Plasmodium spp. (3\%) and 20 positive for Haemoproteus spp. (15\%), with seven different cytb lineages (three of Plasmodium and four of Haemoproteus lineages), of which five were obtained from resident birds and two from migratory birds (Table 1). We detected four new lineages: (1) C. livia (sample identification number, ID 481) presented a sequence with $98 \%$ of identity with the lineage AFR119 (Haemoproteus sp.); (2) D. viduata (ID 263) presented a sequence with $98 \%$ of identity with STUSUP02 and VIOLI07 (Plasmodium sp.); (3) D. viduata (ID 249) presented a sequence with $99 \%$ of identity with GRW06 (Plasmodium elongatum); and (4) P. superciliaris (ID 885) and $N$. nycticorax (ID 854) presented a sequence with $99 \%$ of identity with PESA01 (Plasmodium sp.). Three Haemoproteus lineages had been already deposited in MalAvi: HAECOL1, COQUI05, and COLIV03. However, only the first one has been attributed to certain morphospecies (H. columbae).

The phylogenetic reconstruction of Haemoproteus spp. lineages showed two well-supported clusters (posterior probability is of $100 \%$ ), corresponding to each subgenus of this genus (Fig. 3, clades a and b). One included species of the subgenus Haemoproteus (Haemoproteus), with H. columbae lineage HAECOL1, Haemoproteus multipigmentatus and 


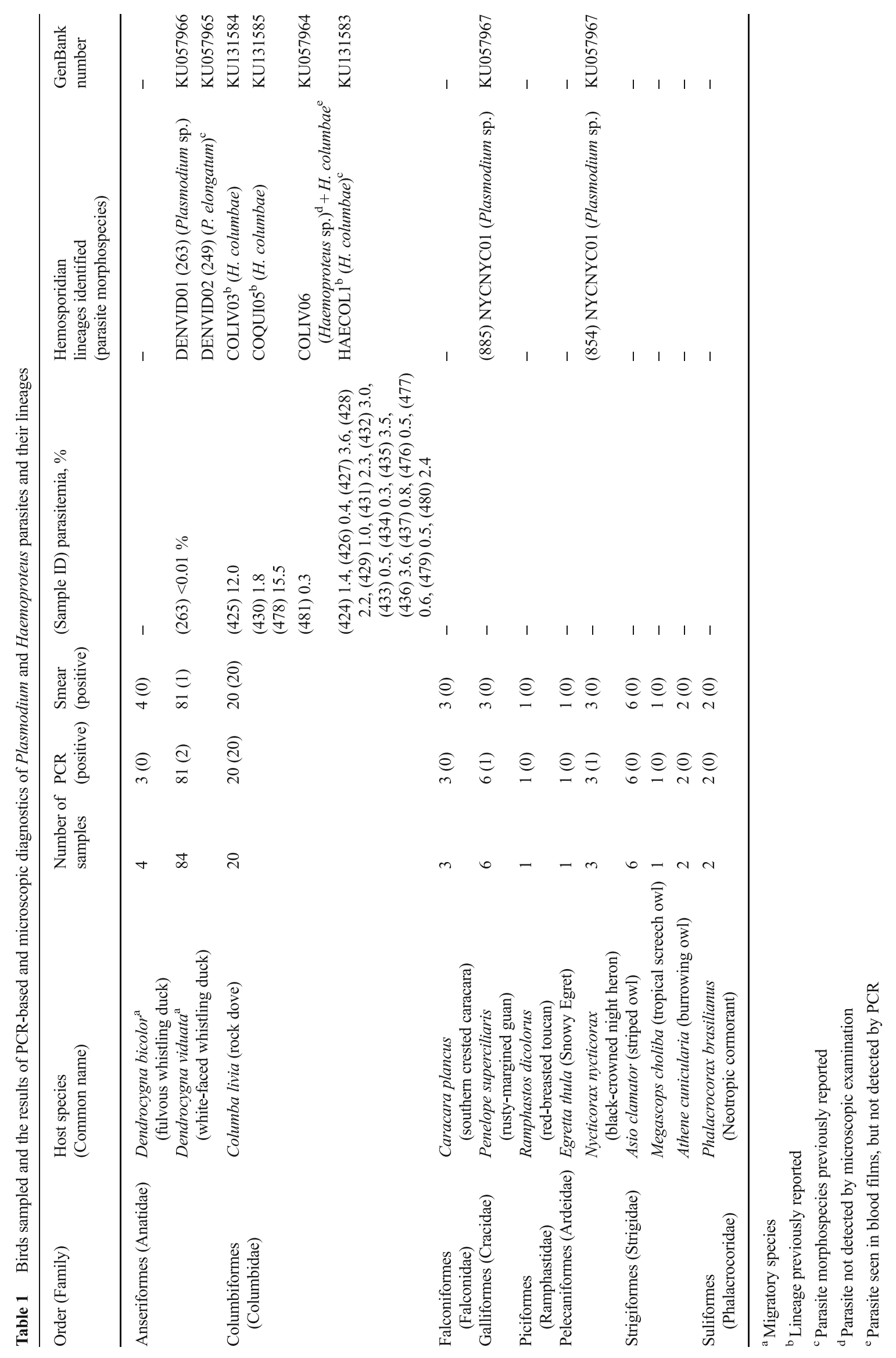


Fig. 2 Haemoproteus

(Haemoproteus) columbae gametocytes from the blood of Columba livia (rock pigeon) in São Paulo Zoo. Bird ID 425 (lineage COLIV03): macrogametocytes, $\mathbf{a}-\mathbf{b}$ and microgametocytes, $\mathbf{c}-\mathbf{d}$; Bird ID 430 (lineage COQUI05): macrogametocytes, $\mathbf{e}-\mathbf{f}$ and microgametocytes, $\mathbf{g}-\mathbf{h}$; Bird ID 478 (lineage COQUI05): macrogametocytes, $\mathbf{i}-\mathbf{j}$ and microgametocytes, $\mathbf{k}-\mathbf{l}$; Bird ID 481 (this parasite was readily seen in blood films, but was not detected by PCR):

macrogametocytes, $\mathbf{m}-\mathbf{n}$ and microgametocytes, o-p. Note large aggregations of volutin and pigment granules readily visible in microgametocytes of all lineages of this parasite. Giemsastained thin blood films. Bar $=10 \mu \mathrm{m}$
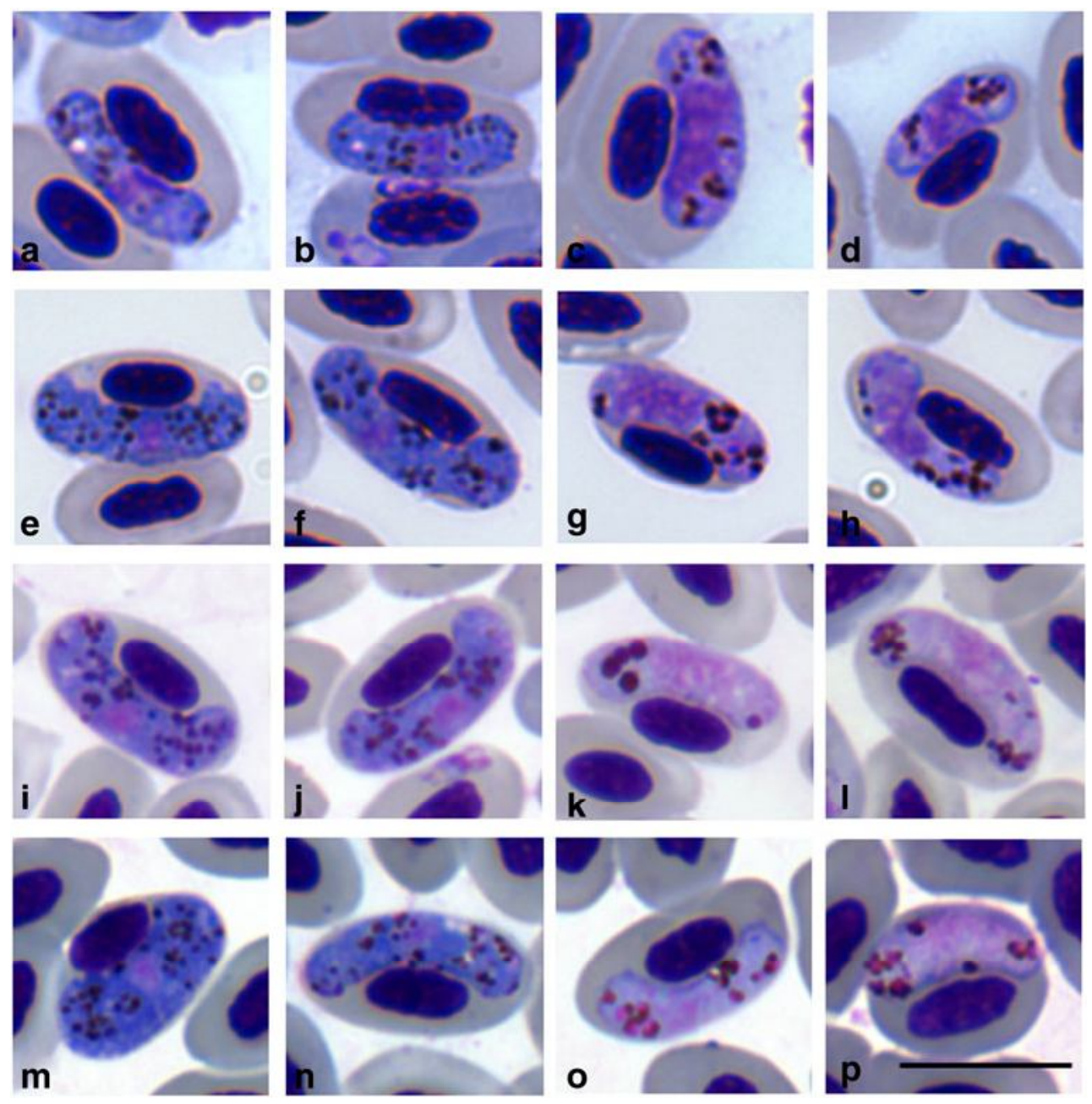

Haemoproteus iwa. The other included species belonging to the subgenus Haemoproteus (Parahaemoproteus). All Haemoproteus sequences obtained from doves in this study clustered with subgenus Haemoproteus (Haemoproteus). The majority of them appeared closely related with $H$. columbae lineage HAECOL1, while the sequence obtained in C. livia (ID 481) clustered with $H$. multipigmentatus and $H$. iwa. No Parahaemoproteus parasite lineages were reported in this study.

The phylogenetic tree of Plasmodium spp. (Fig. 4) showed low phylogenetic resolution, and morphospecies belonging to different subgenera (Haemamoeba, Giovannolaia, Novyella, Bennettinia, and Huffia) were included in more than one clade. However, the sequences recovered from $P$. superciliares (ID 885) and N. nycticorax (ID 854) grouped with a wellsupported cluster with the majority of $P$. (Haemamoeba) sequences ( $94 \%$ of posterior probability); the sequence recovered from D. viduata (ID 263) (DENVID01) grouped with a well-supported cluster containing exclusively $P$. (Novyella) sequences (96\% of posterior probability); and the sequence recovered from $D$. viduata (ID 249)
(DENVID02) grouped with the only $P$. (Huffia) sp. sequence available in the tree, with a high posterior probability $(100 \%)$.

\section{Discussion}

This study adds to the better understanding of the occurrence and genetic diversity of Plasmodium and Haemoproteus parasites in different groups of birds living freely in the São Paulo Zoo. The majority of examined birds belonged to the Anatidae species, among which two migrant species were investigated and one was found positive. This was Dendrocygna viduata (white-faced whistling duck), a species found in Africa, including Madagascar and Comores Islands, Central America Islands, and South America, including Brazil. Dendrocygna javanica, D. viduata, and D. autunnalis had been previously observed infected with Plasmodium sp. (Beadell et al. 2004; Valkiunas 2005). In this study, we found two white-faced whistling ducks positive for Plasmodium lineages, with two different new lineages 


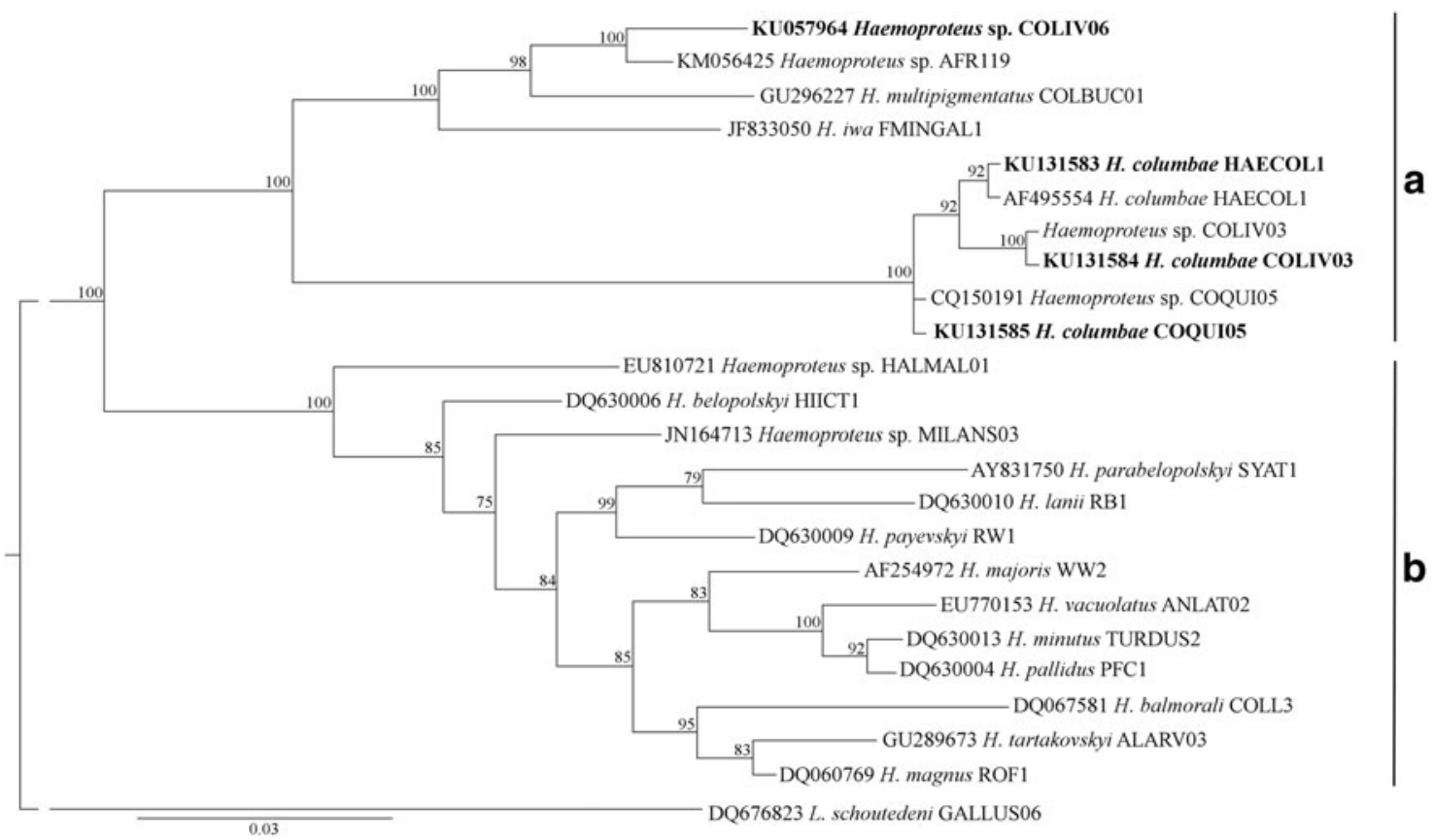

Fig. 3 Bayesian phylogeny of cytochrome $b$ gene lineages of Haemoproteus species of avian hemosporidian parasites. Lineages recorded in this work are given bolded. Names of the lineages are given after the species names of parasites. GenBank accession numbers of the

(DENVID01 and DENVID02). The lineage DENVID01 is similar ( $98 \%$ of identity) to two different lineages (STUSUP02 and VIOLI07), which, in turn, have $97 \%$ of identity with each other. The lineage DENVID02 shows high identity ( $99 \%$ of similarity due to a C-T nucleotide substitution at position 186) to a sequence that has already been characterized as P. elongatum (GRW06), the cosmopolitan and lineages are provided before the parasite species names. Nodal support values (in percentage) indicate posterior clade probabilities. a Species of the subgenus Haemoproteus (Haemoproteus). b Species belonging to the subgenus Haemoproteus (Parahaemoproteus)

virulent parasite in many bird species (Garnham 1966; Valkiūnas et al. 2008). The lineage DENVID01 has been reported before in other birds (mainly belonging to the Anatidae) in the São Paulo Zoo (K. Kirchgatter, unpublished observation). Inversely, the lineage DENVID02 has not been found in other infected bird species in the Zoo (K. Kirchgatter, unpublished observations). This lineage was confirmed in
Fig. 4 Bayesian phylogeny of cytochrome $b$ gene lineages of Plasmodium species of avian hemosporidian parasites. Lineages recorded in this work are given bolded. Names of the lineages are given after the species names of parasites. GenBank accession numbers of the lineages are provided before the parasite species names. Nodal support values (in percentage) indicate posterior clade probabilities

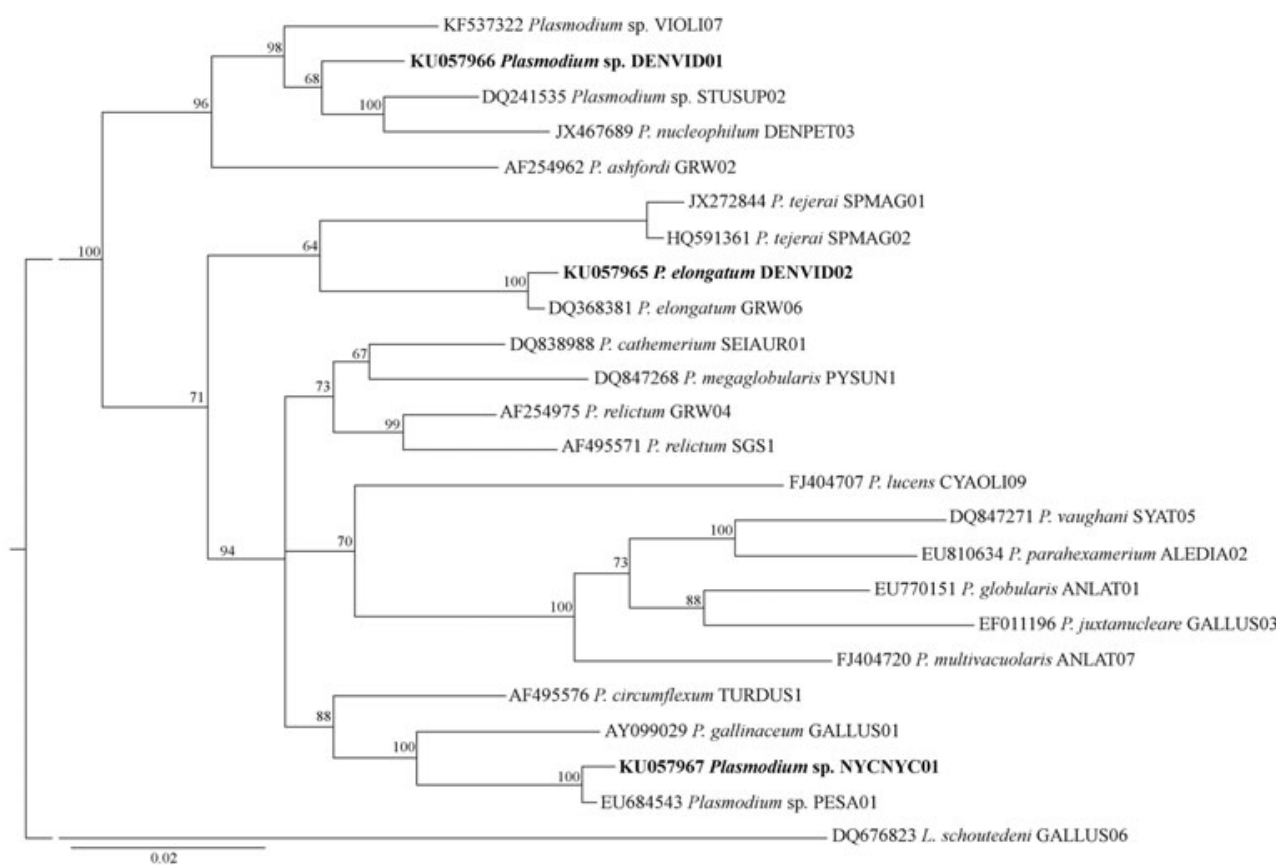


different assays of PCR and sequencing, indicating a possibility that this bird came to the Zoo being already infected. In response to seasonal fluctuations in food and water availability, the white-faced whistling duck may undertake short migrations (usually less than $500 \mathrm{~km}$ ) in search of favorable foraging grounds (Madge and Burn 1988; del Hoyo et al. 1992). Their migration is conditioned to the availability of water bodies (Carboneras and Kirwan 2014) and they may use even the polluted ones (Sick 1997). Considering the wide extension of Brazil, the migratory distance of $500 \mathrm{~km}$ by D. viduata populations allows us to determine the origin of São Paulo State's populations only to this country, and probably ranging from South to Southeast, as these birds usually look for sites with warm temperatures. Plasmodium elongatum (here the lineage DENVID02) has a wide range of distribution, and it is of broad specificity having been reported in birds belonging to ten different orders (see MalAvi and Garnham 1966; Valkiūnas 2005), including magellanic penguins from southern Brazil (Vanstreels et al. 2014a).

Birds of the Columbidae family were the second most largely sampled group in this study, with 20 individual rock doves (Columba livia) tested. This bird was introduced to Brazil in XVI century from Europe, and it became well adapted to the urban environment due to its ecological plasticity in the ability to inhabit different environments (Sigrist 2014), particularly those located close to human settlements (Sick 1997; Develey and Endrigo 2011). Despite some studies showing its ability to migrate over hundreds of kilometers, the native populations have been considered sedentary (Baptista et al. 1997). In São Paulo Zoo, the birds usually find food and shelter easily, and that contributes to the spread of the populations. Four different lineages of hemosporidians were found in C. livia from São Paulo Zoo: (1) the lineage HAECOL1 has been formerly found in $C$. livia in several countries: Botswana, Nigeria, Colombia, and Italy (Waldenstrom et al. 2002; Karamba et al. 2012; Gonzalez et al. 2015; Scaglione et al. 2015); (2) COQUI05 has been found in Coquillettidia (Culicidae, Diptera) mosquitoes from Cameroon (Njabo et al. 2009); (3) COLIV03 has already been found in C. livia from Nigeria (Karamba et al. 2012); (4) COLIV06 is a new sequence, and possibly it belongs to a Haemoproteus species since it showed $10 \%$ of genetic distance with other sequences from HAECOL1 group. However, the bird with COLIV06 was probably co-infected whereas parasites that could present this sequence were not visible during microscopic examination of blood films. Absence of gametocytes in birds PCR positive for hemosporidian parasites has been described and can be explained by light gametocyte parasitemia, amplification of DNA of circulating sporozoites (Valkiūnas et al. 2009), or even the presence of remnants of parasites, which abort development during tissue stage of development (Ferrell et al. 2007; Donovan et al. 2008; Olias et al. 2011; Chagas et al. 2013). COQUI05 and COLIV03 sequences showed 1-
$2 \%$ of genetic distances with HAECOL1 group sequences and were confirmed by microscopy in this study as H. columbae (Fig. 2), a parasite widespread in at least 14 species of the Columbiformes (Valkiūnas 2005).

Haemoproteus spp. is the most common blood parasite in birds, followed by Leucocytozoon spp. and Plasmodium spp. (Garnham 1966; Valkiūnas 2005). However, in South America, Haemoproteus lineage diversity does not follow the high diversity found among avian and mosquito species (Clark et al. 2014). It is possible that a bias to preferential amplification of Plasmodium cytb sequences exists (Valkiūnas et al. 2006). During this study, we found 83 and $17 \%$ of the positive free-living birds infected with Haemoproteus spp. and Plasmodium spp., respectively, while Leucocytozoon spp. has not been observed in the lowlands of Brazil (Valkiūnas 2005). The high prevalence of Haemoproteus spp. reported in this study is somewhat striking since only $2 \%$ of the positive captive birds of the same region have been found infected with this parasite (K. Kirchgatter, unpublished observation). However, this difference can be attributed to a bias due to high rate of infection found in rock doves. High prevalence $(100 \%)$ of Haemoproteus infection is consistent with that found in a study, which examined rock doves in the State of São Paulo (Adriano and Cordeiro 2001).

Columba livia, in its natural habitat, plays an important ecological role, controlling the population of insects and spreading some seeds. As invasive species in the study area and big cities such São Paulo, it is known as a sinantropic animal, competing with local species. However, the parasites that rock doves harbor can be transmitted to other columbiform birds, compromising their fitness. C. livia has a status of least concern (IUCN RED LIST 2015), but in São Paulo county, where PEFI locates, not only rock doves are present but also other species of Columbiformes, such as Columbina talpacoti, Patagioenas picazuro, Patagioenas cayennensis, Patagioenas plumbea, Patagioenas speciose, Zenaida auriculata, Geotrygon montana, Geotrygon violacea, Leptotila verreauxi, and L. rufaxilla (http://www. prefeitura.sp.gov.br/cidade/secretarias/upload/meio ambiente/arquivos/TRE_EIA.pdf). Although Haemoproteus sp. usually does not cause clinical disease in adapted avian hosts (Valkiūnas 2005), infections with this parasite causing sudden death in non-adapted passerine birds have been reported in San Diego Zoo, USA (Donovan et al. 2008). Haemoproteus (Parahaemoproteus) parasites cause severe disease in some bird species in Europe and Australia (Olias et al. 2011; Cannell et al. 2013) and can be lethal for bloodsucking insects (Valkiūnas et al. 2014). Because rock doves have expanded their range into environmental conservation areas, there is a greater risk of spreading its infections to the native fauna; therefore, population control activities with these birds can be required. 
We also found infected Penelope superciliaris and Nycticorax nycticorax. The former bird is the most wellknown species of the Cracidae family, which includes 50 species and 20 of them are present in Brazil (Del Hoyo and Kirwan 1994; CBRO 2014). Penelope superciliaris is found from north to south of Brazil, Paraguay, and north of Argentina (Guix 1997). This species eats basically insects, flowers, and fallen fruits, which makes it an important seed disperser in the forest ecosystems (Del Hoyo and Kirwan 1994; Mikich 2002; Sick 1997). Nycticorax nycticorax (Ardeidae) has nightly and twilight habits (CBRO 2014) and can be found living close to water from Canada to south Argentina, including Old World where it has migration habits (Martinez-Vilalta et al. 2014). Its diet consists of fish, crustaceans, amphibians, mollusks, crabs, aquatic insects, polychaetes, small lizards, snakes, rodents, bats, eggs and chicks, and occasionally carcass (Sick 1997). In São Paulo Zoo, it is an opportunistic bird that does not belong to the park, but lives in the neighborhood and feeds using remnants of food of captive animals. Thus, living freely in the area of the zoo, such birds can rapidly take advantage of favorable conditions when they arise. In a report of Plasmodium sp. causing mortality in penguins from São Paulo Zoo, we detected a mosquito engorged with $N$. nycticorax blood (Bueno et al. 2010). As these birds were frequently found inside the penguin enclosures feeding on the leftover of fish, they might be a source of Plasmodium infections for other bird species in São Paulo Zoo. According to MalAvi database, the lineage found in $N$. nycticorax (PESA01) has been found in three different hosts of three different orders: Phaeomyias murina, a passeriform species from Brazil (Lacorte et al. 2013); Calidris melanotos, a migratory wader from Alaska (Yohannes et al. 2009); and Leptotila verreauxi, a Columbidae species from Uruguay (Durrant et al. 2006), showing a generalist parasite that may infect a broad range of avian hosts. However, it is impossible to proceed species identification using only the sequence information since a small genetic difference ( $96 \%$ or less of identity) was reported in readily distinguishable hemosporidian morphospecies, all of Haemamoeba subgenus. Additional morphologic studies are needed to determine Plasmodium species identity of the PESA01 lineage.

We also tested owls that live freely in the Zoo. Although none was found infected in our study, hemosporidian parasites, mainly Haemoproteus parasites, are widespread in owls worldwide and have been found in the USA (Tavernier et al. 2005; Ishak et al. 2008), Europe (Krone et al. 2008; Bukauskaite et al. 2015), Africa (Ishak et al. 2008), Asia (McClure et al. 1978), and South America (White et al. 1978). The prevalence of infections exceeds $50 \%$ in many owl populations worldwide (Valkiūnas 2005). Owl haemoproteids belong to the subgenus Parahaemoproteus and are transmitted by biting midges of the genus Culicoides
(Bukauskaite et al. 2015). In São Paulo State, one individual of Megascops choliba sampled in 2009 at Carapicuíba was found positive for Haemoproteus syrnii (Vanstreels et al. 2014b). The absence of positives among the owl samples in our study could reflect the low number of birds tested here (nine samples of three birds). However, all the 35 samples tested from captive birds of Strigiformes order from the same area were negative by PCR (K. Kirchgatter, unpublished observation). This result might indicate weak transmission of Parahaemoproteus parasites due to the absence of susceptible species of biting midges at our study site warranting further investigation.

The cost of the infections to the birds depends on many factors, including the age, host immunity, breeding season, migration, and food availability (Sorci and Cornet 2010). In captivity, the animals do not usually need to compete for food, territory, or females, decreasing these stress levels that would affect animals under natural conditions. Wild animals sampled in this study have access to food from the captive animals. Since parasites can influence the biodiversity and the structure of host populations by altering the competitive interaction between the free-living and the captive birds, biodiversity preservation studies should be considered in areas with these two animal communities.

Acknowledgments We thank Prof. Dr. Claudio Marinho for kindly providing the use of Zeiss Axio Imager M2 light microscope equipped with a Zeiss Axio Cam HRc in which the photographs of this paper were produced. We thank the São Paulo Zoological Park Foundation (Fundação Parque Zoológico de São Paulo) for the support provided to this research. This research was funded by Fundação de Amparo a Pesquisa do Estado de São Paulo (FAPESP 2012/51427-1). All procedures were approved by the Ethical Principles in Animal Research, of the Ethics Committee of Institute of Tropical Medicine, University of São Paulo (CPE-IMT/193), and were in full compliance with federal permits issued by the Brazilian Ministry of the Environment (SISBIO 35166-2, 41010-1, and 34605-2).

\section{References}

Adriano EA, Cordeiro NS (2001) Prevalence and intensity of Haemoproteus columbae in three species of wild doves from Brazil. Mem Inst Oswaldo Cruz 96:175-178

Altschul SF, Madden TL, Schäffer AA, Zhang J, Zhang Z, Miller W, Lipman DJ (1997) Gapped BLAST and PSI-BLAST: a new generation of protein database search programs. Nucleic Acids Res 25: 3389-3402

Arzua M, Valim MP (2010) Bases para o estudo qualitativo e quantitativo em aves. In: Matter SV, Strauber FC, Accordi I, Piacentini V, Cândido JF Jr (eds) Ornitologia e Conservação: Ciência Aplicada, Técnicas de Pesquisa e Levantamento. Technical Books, Rio de Janeiro, pp 347-366

Atkinson CT, Thomas NJ, Hunter BC (2008) Parasitic diseases of wild birds. Wiley-Blackwell, Ames

Baptista LF, Trail PW, Horblit HM (1997) Rock dove (Columba livia). In: del Hoyo J, Elliott A, Sargatal J, Christie DA, de Juana E (eds) (2014). Handbook of the birds of the world alive. Lynx Edicions, 
Barcelona, Acesso: http://www.hbw.com/node/54097 em 26 de julho de 2015

Beadell JS, Gering E, Austin J, Dumbacher JP, Peirce MA, Pratt TK, Atkinson CT, Fleischer RC (2004) Prevalence and differential host-specificity of two avian blood parasite genera in the AustraloPapuan region. Mol Ecol 13:3829-3844

Belo NO, Passos LF, Júnior LM, Goulart CE, Sherlock TM, Braga EM (2009) Avian malaria in captive psittacine birds: detection by microscopy and 18S rRNA gene amplification. Prev Vet Med 88:220 224

Bensch S, Hellgren O, Pérez-Tris J (2009) MalAvi: a public database of malaria parasites and related haemosporidians in avian hosts based on mitochondrial cytochrome b lineages. Mol Ecol Resour 9:13531358

Bueno MG, Lopez RPG, Menezes RMT, Costa-Nascimento MJ, Lima GFMC, Araújo RAS, Guida FJV, Kirchgatter K (2010) Identification of Plasmodium relictum causing mortality in penguins (Spheniscus magellanicus) from São Paulo Zoo, Brazil. Vet Parasitol 173:123-127

Bukauskaite D, Žiegytė R, Palinauskas V, Iezhova TA, Dimitrov D, Ilgūnas M, Bernotienė R, Markovets MY, Valkiūnas G (2015) Biting midges (Culicoides, Diptera) transmit Haemoproteus parasites of owls: evidence from sporogony and molecular phylogeny. Parasit Vectors 8:303

Cannell BL, Krasnec KV, Campbell K, Jones HI, Miller RD, Stephens N (2013) The pathology and pathogenicity of a novel Haemoproteus spp. infection in wild Little Penguins (Eudyptula minor). Vet Parasitol 197:74-84

Carboneras C, Kirwan GM (2014) White-faced whistling-duck (Dendrocygna viduata). In: del Hoyo J, Elliott A, Sargatal J, Christie DA, de Juana E (eds) 2014. Handbook of the birds of the world alive. Lynx Edicions, Barcelona, Acesso: http://www.hbw. com/node/52799 em 26 de julho de 2015

CBRO (2014) Comitê brasileiro de registros ornitológicos. Listas das aves do Brasil 11ª Edição. http://www.cbro.org.br. Accessed: January 01,2014

CEMAVE/IBAMA (1994) Manual de anilhamento de aves silvestres, 2nd edn. IBAMA, Brasília, p 146

Chagas CRF, Valkiūnas G, Nery CVC, Henrique PC, Gonzalez IHL, Monteiro EF, Guimarães L, Kirchgatter K (2013) Plasmodium (Novyella) nucleophilum from Egyptian Goose in São Paulo Zoo, Brazil: microscopic confirmation and molecular characterization. Int J Parasitol Parasites Wildl 2:286-291

Clark NJ, Clegg SM, Lima MR (2014) A review of global diversity in avian haemosporidians (Plasmodium and Haemoproteus: Haemosporida): new insights from molecular data. Int J Parasitol 44:329-338

Del Hoyo J, Kirwan GM (1994) Rusty-margined Guan (Penelope superciliaris). In: del Hoyo J, Elliott A, Sargatal J, Christie DA, de Juana E (eds) Handbook of the birds of the world, vol 2, New World vultures to guineafowl. Lynx Edicions, Barcelona, pp 348-350

del Hoyo J, Elliott A, Sargatal J (1992) Handbook of the birds of the world. Volume 1: ostrich to ducks. Lynx Edicions, Barcelona

Develey PF, Endrigo E (2011) Guia de campo: Aves da Grande São Paulo. Aves e Fotos Editora, São Paulo

Donovan TA, Schrenzel M, Tucker TA, Pessier AP, Stalis IH (2008) Hepatic hemorrhage, hemocoelom, and sudden death due to Haemoproteus infection in passerine birds: eleven cases. J Vet Diagn Invest 20:304-313

Durrant KL, Beadell JS, Ishtiaq F, Graves GR, Olson SL, Gering E, Peirce MA, Milensky CM, Schmidt BK, Gebhard C, Fleischer RC (2006) Avian hematozoa in South America: a comparison of temperate and tropical zones. Ornit Monographs 60:98-111

Felippe-Bauer ML, Oliveira SJ (2001) Lista dos exemplares tipos de Ceratopogonidae (Diptera: Nematocera) depositados na Coleção
Entomológica do Instituto Oswaldo Cruz, Rio de Janeiro, Brasil. Mem Inst Oswaldo Cruz 96:1109-1119

Ferrell ST, Snowden K, Marlar AB, Garner M, Lung NP (2007) Fatal hemoprotozoal infections in multiple avian species in a zoological park. J Zoo Wildl Med 38:309-316

Garnham PCC (1966) Malaria parasites and other haemosporidia. Blackwell Scientific, Oxford

Godfrey RD, Fedynich AM, Pence DB (1987) Quantification of the hematozoa in blood smears. J Wildl Dis 23:558-565

González AD, Lotta IA, García LF, Moncada LI, Matta NE (2015) Avian haemosporidians from Neotropical highlands: evidence from morphological and molecular data. Parasitol Int 64:48-59

Guix JC (1997) Exclusão geográfica e ecológica de Penelope obscura, Penelope superciliaris e Pipile jacutinga (Galliformes, Cracidae) no estado de São Paulo. Ararajuba 5:195-202

Hellgren O, Waldenström J, Bensch S (2004) A new PCR assay for simultaneous studies of Leucocytozoon, Plasmodium and Haemoproteus from avian blood. J Parasitol 90:797-802

Huelsenbeck JP, Ronquist F (2001) MRBAYES: Bayesian inference of phylogenetic trees. Bioinformatics 17:754-755

IUCN Red List (2015) [http://www.iucnredlist.org/]

Ishak HD, Dumbacher JP, Anderson NL, Keane JJ, Valkiūnas G, Haig SM, Tell LA, Sehgal RN (2008) Blood parasites in owls with conservation implications for the Spotted Owl (Strix occidentalis). PLoS One 3:e2304

Karamba KI, Kawo AH, Dabo NT, Mukhtar MD (2012) A survey of avian malaria parasite in Kano State, Northern Nigeria. Int $\mathrm{J}$ Biotechnol Mol Biol Res 3:8-14

Krone O, Waldenström J, Valkiūnas G, Lessow O, Müller K, Iezhova TA, Fickel J, Bensch S (2008) Haemosporidian blood parasites in European birds of prey and owls. J Parasitol 94:709-715

Lacorte GA, Félix GM, Pinheiro RR, Chaves AV, Almeida-Neto G, Neves FS, Leite LO, Santos FR, Braga EM (2013) Exploring the diversity and distribution of neotropical avian malaria parasites - a molecular survey from Southeast Brazil. PLoS One 8:e57770

Madge S, Burn H (1988) Wildfowl. Christopher Helm, London

Martínez-Vilalta A, Motis A, Kirwan GM (2014) Black-crowned Nightheron (Nycticorax nycticorax). In: del Hoyo J, Elliott A, Sargatal J, Christie DA, de Juana E (eds) Handbook of the birds of the world alive. Barcelona, Lynx Edicions, Acesso: http://www.hbw.com/ node/52707 em 30 de julho

McClure HE, Poonswad P, Greiner EC, Laird M (1978) Haematozoa in the birds of Eastern and Southern Asia. St. John's: Memorial University of Newfoundland.

Mikich AB (2002) A dieta frugívora de Penelope superciliaris (Cracidae) em remanescentes de florestas estacional semidecidual no centrooeste do Paraná, Brasil e sua relação com Euterpe edulis (Arecaceae). Ararajuba 10:207-217

Motta ROC, Marques MVR, Ferreira JRFC, Andery DA, Horta RS, Peixoto RB, Lacorte GA, Moreira PA, Leme FOP, Melo MM, Martins NRS, Braga EM (2013) Does haemosporidian infection affect hematological and biochemical profiles of the endangered Black-fronted piping-guan (Aburria jacutinga)? PeerJ 1:e45

Njabo KY, Cornel AJ, Sehgal RN, Loiseau C, Buermann W, Harrigan RJ, Pollinger J, Valkiūnas G, Smith TB (2009) Coquillettidia (Culicidae, Diptera) mosquitoes are natural vectors of avian malaria in Africa. Malar J 8:193

Olias P, Wegelin M, Zenker W, Freter S, Gruber AD, Klopfleisch R (2011) Avian malaria deaths in parrots, Europe. Emerg Infect Dis 17:950-952

Orme CD, Davies RG, Burgess M, Eigenbrod F, Pickup N, Olson VA, Webster AJ, Ding TS, Rasmussen PC, Ridgely RS, Stattersfield AJ, Bennett PM, Blackburn TM, Gaston KJ, Owens IP (2005) Global hotspots of species richness are not congruent with endemism or threat. Nature 436:1016-1019 
Rambaut A (2006) FigTree tree figure drawing toll version 1.4.0. Institute of Evolutionary Biology, University of Edinburgh [http://tree.bio.ed. ac.uk/software/figtree/).

Ribeiro SF, Sebaio F, Branquinho FC, Marini MA, Vago AR, Braga EM (2005) Avian malaria in Brazilian passerine birds: parasitism detected by nested PCR using DNA from stained blood smears. Parasitology 130:261-267

Ribeiro MC, Metzger JP, Martensen AC, Ponzoni FJ, Hirota MM (2009) The Brazilian Atlantic Forest: how much is left, and how is the remaining forest distributed? Implications for conservation. Biol Conserv 142:1141-1153

Scaglione FE, Pregel P, Cannizzo FT, Pérez-Rodríguez AD, Ferroglio E, Bollo E (2015) Prevalence of new and known species of haemoparasites in feral pigeons in northwest Italy. Malar J 14:99

Sebaio F, Braga EM, Branquinho F, Fecchio A, Marini MÂ (2012) Blood parasites in passerine birds from the Brazilian Atlantic Forest. Rev Bras Parasitol Vet 21:7-15

Sick H (1997) Ornitologia Brasileira, uma introdução. Nova Fronteira, Rio de Janeiro

Sigrist T (2014) Guia de campo Avis Brasilis-Avifauna Brasileira. Avis Brasilis, São Paulo, p 608

Sorci G, Cornet S (2010) Immunity and virulence in bird-parasite interactions. Open Ornithol J 3:33-40

Tavernier P, Saggese M, Van Wettere A, Redig P (2005) Malaria in an eastern screech owl (Otus asio). Avian Dis 49:433-435

Valkiūnas G (2005) Avian malaria parasites and other haemosporidia. CRC Press, New York, p 935

Valkiūnas G, Bensch S, Iezhova TA, Krizanauskiené A, Hellgren O, Bolshakov CV (2006) Nested cytochrome b polymerase chain reaction diagnostics underestimate mixed infections of avian blood haemosporidian parasites: microscopy is still essential. J Parasitol 92: $418-422$
Valkiūnas G, Zehtindjiev P, Dimitrov D, Krizanauskiene A, Iezhova TA, Bensch S (2008) Polymerase chain reaction-based identification of Plasmodium (Huffia) elongatum, with remarks on species identity of haemosporidian lineages deposited in GenBank. Parasitol Res 102: $1185-1193$

Valkiūnas G, Iezhova T, Loiseau C, Thomas S, Sehgal RNM (2009) Nested cytochrome B polymerase chain reaction diagnostics detect sporozoites of hemosporidian parasites in peripheral blood of naturally infected birds. J Parasitol 95:1512-1525

Valkiūnas G, Kazlauskienė R, Bernotienė R, Bukauskaitė D, Palinauskas V, Iezhova TA (2014) Haemoproteus infections (Haemosporida, Haemoproteidae) kill bird-biting mosquitoes. Parasitol Res 113: 1011-1018

Vanstreels RET, Kolesnikovas CKM, Sandri S, Silveira P, Belo NO, Ferreira Junior FC, Epiphanio S, Steindel M, Braga EM, CatãoDias JL (2014a) Outbreak of avian malaria associated to multiple species of Plasmodium in magellanic penguins undergoing rehabilitation in southern Brazil. PLoS One 9:e94994

Vanstreels RET, Kolesnikovas CKM, Sandri S, Silveira P, Belo NO, Ferreira Junior FC, Epiphanio S, Steindel M, Braga EM, CatãoDias JL (2014b) Correction: Outbreak of avian malaria associated to multiple species of Plasmodium in magellanic penguins undergoing rehabilitation in southern Brazil. PLoS One 9:e116554

Waldenström J, Bensch S, Kiboi S, Hasselquist D, Ottosson U (2002) Cross-species infection of blood parasites between resident and migratory songbirds in Africa. Mol Ecol 11:1545-1554

White EM, Greiner EC, Bennett GF, Herman CM (1978) Distribution of the hematozoa of Neotropical birds. Rev Biol Trop 26:43-102

Yohannes E, Križanauskiene A, Valcu M, Bensch S, Kempenaers B (2009) Prevalence of malaria and related haemosporidian parasites in two shorebird species with different winter habitat distribution. $\mathbf{J}$ Ornithol 150:287-291 
APÊNDICE D - Artigo em preparação para submissão ao Malar J. "DIVERSITY AND DISTRIBUTION OF AVIAN MALARIA AND RELATED

HAEMOSPORIDIAN PARASITES IN CAPTIVE BIRDS FROM A BRAZILIAN MEGALOPOLIS". 


\section{DIVERSITY AND DISTRIBUTION OF AVIAN MALARIA AND RELATED}

\section{HAEMOSPORIDIAN PARASITES IN CAPTIVE BIRDS FROM A}

\section{BRAZILIAN MEGALOPOLIS}

6 Carolina Romeiro Fernandes Chagas ${ }^{1 *}$, Gediminas Valkiūnas ${ }^{2}$, Lilian de Oliveira

7 Guimarães ${ }^{3}$, Eliana Ferreira Monteiro ${ }^{3}$, Fernanda Junqueira Vaz Guida ${ }^{1}$, Roseli França

8 Simões $^{3}$, Priscila Thihara Rodrigues ${ }^{4}$, Expedito José de Albuquerque Luna ${ }^{5}$, Karin

$9 \quad$ Kirchgatter $^{3}$

10

$11{ }^{1}$ São Paulo Zoo Foundation, Av. Miguel Estéfano 4241, São Paulo, SP 04301-905, 12 Brazil

$14{ }^{2}$ Nature Research Centre, Akademijos 2, Vilnius LT-08412, Lithuania

$16{ }^{3}$ Malaria Research Center, Superintendence for Endemic Disease Control, São Paulo

17 Institute of Tropical Medicine, University of São Paulo, Av. Dr. Enéas de Carvalho

18 Aguiar 470, São Paulo, SP 05403-000, Brazil

${ }^{4}$ Department of Parasitology, Institute of Biomedical Sciences, University of São

21 Paulo, Av. Prof. Lineu Prestes 1374, São Paulo, SP 05508-900, Brazil

$23{ }^{5}$ Virology Laboratory, Institute of Tropical Medicine, University of São Paulo, Av. Dr.

24 Enéas de Carvalho Aguiar 470, São Paulo, SP 05403-000, Brazil 


\section{$1 \quad$ Abstract (350 words)}

2 Background: The role of zoos in conservation programs has increased significantly in

3 last decades, and the health of captive animals is essential to guarantee success of such

4 programs. However, zoo birds suffer from parasitic infections, which often are caused

5 by malaria parasites and related haemosporidians. Studies determining the occurrence

6 and diversity of these parasites, aiming better understanding infection influence on

7 fitness of captive birds, are limited.

8 Methods: In 2011-2015, the prevalence and diversity of Plasmodium spp. and

9 Haemoproteus spp. was examined in blood samples of 677 captive birds from the São

10 Paulo Zoo, the largest zoo in Latin America. Molecular and microscopic diagnostic

11 methods were used in parallel to detect and identify these infections.

12 Results: The overall prevalence of haemosporidians was $12.6 \%$. Parasites were mostly

13 detected by the molecular diagnosis, indicating that many birds harbour subclinical or

14 abortive infections. We tested birds of 17 orders (almost half of all the orders currently

15 accepted in taxonomy of birds), 29 families, and 122 species, detecting positive

16 individuals in $27 \%$ of bird species. Birds from the Anatidae were the most prevalently

17 infected (64.7\% of all infected animals). In all, infections with parasites of the genus

18 Plasmodium (overall prevalence 97.6\%) predominated when compared to those of the

19 genus Haemoproteus (2.4\%). In total, 14 cytochrome b (cytb) lineages of Plasmodium

20 spp. and 2 cytb lineages of Haemoproteus spp. were recorded. Eight lineages were new.

21 One of the reported lineages was broad generalist while others were reported in single

22 or a few species of birds. Molecular characterization of Haemoproteus ortalidum was

23 developed.

24 Conclusion: This study shows that many species of birds are at risk in captivity. It is

25 difficult to stop haemosporidian parasite transmission in zoos, but is possible to reduce 
1 the infection rate by treating the infected animals or/and while keeping them in facilities

2 free from mosquitoes. Protocols of quarantine should be implemented whenever an

3 animal is transferred between bird maintaining institutions. This is the first survey of

4 haemosporidians in captive birds from different orders maintained in zoos. We

5 emphasize the necessity of applying practices to control these parasites in management

6 and husbandry of animals in captivity.

7

8 Keywords: avian malaria, Plasmodium, Haemoproteus, captive birds, zoo,

9 conservation.

\section{Background}

12 Wild animals have been maintained in captivity since ancient Egypt, and this

13 represented the status and power. Around $18^{\text {th }}$ century, these animals started broadly

14 kept in private collections, closed to general public, mostly for entertainment [1].

15 Through the years, these collections were gradually transformed into zoos, which since

161960 s, their main concern has turned to species conservation by providing them with a

17 healthy environment. The role of zoos in wild life conservation has markedly increased

18 along the last decades. Nowadays, they act in environmental education, research,

19 management, concerning animal welfare, and financing in situ conservation programs

$20[1,2]$.

21 Captive environment can offer to the animals some special conditions not found in the

22 wild, such as enough food, shelter, and protection against predators, besides veterinary

23 care that helps them to survive various diseases [3]. However, parasitic diseases could

24 be common and pose a greater risk in captivity as they can spread easily, leading even to

25 death in some species $[4,5]$. High density of birds is common in captivity; therefore, 
ANEXO A - Autorização para atividades com finalidade científica. SISBIO 34605-6 


\section{Autorização para atividades com finalidade científica}

\section{Número: 34605-7 \\ Data da Emissão: 27/10/2016 20:54 \\ Data para Revalidação*: 26/11/2017}

* De acordo com o art. 28 da IN 03/2014, esta autorização tem prazo de validade equivalente ao previsto no cronograma de atividades do projeto, mas deverá ser revalidada anualmente mediante a apresentação do relatório de atividades a ser enviado por meio do Sisbio no prazo de até 30 dias a contar da data do aniversário de sua emissão.

Dados do titular

Nome: Karin Kirchgatter

CPF: $127.822 .158-17$

Título do Projeto: Plasmodium spp. em aves silvestres da Fundação Parque Zoológico de São Paulo: identificação de espécie por microscopia e código de barras de DNA

Nome da Instituição : Superintendência de Controle de Endemias

CNPJ: 43.142.397/0001-69

Cronograma de atividades

\begin{tabular}{|l|l|l|l|}
\hline$\#$ & \multicolumn{1}{|c|}{ Descrição da atividade } & Início (mês/ano) & Fim (mês/ano) \\
\hline 1 & Coleta de sangue/realização dos esfregaços sanguíneos & $08 / 2012$ \\
\hline 2 & Exame dos esfregaços & $07 / 2015$ \\
\hline 3 & Extração de DNA & $07 / 2016$ \\
\hline 4 & Amplificação de cytb e SSU por PCR & $08 / 2012$ \\
\hline 5 & Sequenciamento dos fragmentos em ABI3100 & $06 / 2013$ \\
\hline 6 & Análise dos dados & $09 / 2016$ & $07 / 2013$ \\
\hline 7 & Relatório & $09 / 2016$ & $07 / 2013$ \\
\hline 8 & Redação do artigo científico & $07 / 2013$ \\
\hline 9 & Coleta de Culicidae & $11 / 2016$ & $12 / 2014$ \\
\hline
\end{tabular}

\section{Observações e ressalvas}

As atividades de campo exercidas por pessoa natural ou jurídica estrangeira, em todo o território nacional, que impliquem o deslocamento de recursos humanos e

1 materiais, tendo por objeto coletar dados, materiais, espécimes biológicos e minerais, peças integrantes da cultura nativa e cultura popular, presente e passada,

obtidos por meio de recursos e técnicas que se destinem ao estudo, à difusão ou à pesquisa, estão sujeitas a autorização do Ministério de Ciência e Tecnologia.

Esta autorização NAO exime o pesquisador titular e os membros de sua equipe da necessidade de obter as anuências previstas em outros instrumentos legais, bem

2 como do consentimento do responsável pela área, pública ou privada, onde será realizada a atividade, inclusive do órgão gestor de terra indígena (FUNAI), da

2 unidade de conservação estadual, distrital ou municipal, ou do proprietário, arrendatário, posseiro ou morador de área dentro dos limites de unidade de conservação

federal cujo processo de regularização fundiária encontra-se em curso.

Este documento somente poderá ser utilizado para os fins previstos na Instrução Normativa ICMBio ${ }^{\circ} 03 / 2014$ ou na Instrução Normativa ICMBio $n^{\circ} 10 / 2010$, no que

3 especifica esta Autorização, não podendo ser utilizado para fins comerciais, industriais ou esportivos. O material biológico coletado deverá ser utilizado para atividades

científicas ou didáticas no âmbito do ensino superior.

4 A autorização para envio ao exterior de material biológico não consignado deverá ser requerida por meio do endereço eletrônico www.ibama.gov.br (Serviços on-line -

4 Licença para importação ou exportação de flora e fauna - CITES e não CITES).

O titular de licença ou autorização e os membros da sua equipe deverão optar por métodos de coleta e instrumentos de captura direcionados, sempre que possível,

5 ao grupo taxonômico de interesse, evitando a morte ou dano significativo a outros grupos; e empregar esforço de coleta ou captura que não comprometa a viabilidade

de populações do grupo taxonômico de interesse em condição in situ.

O titular de autorização ou de licença permanente, assim como os membros de sua equipe, quando da violação da legislação vigente, ou quando da inadequação,

6 omissão ou falsa descrição de informações relevantes que subsidiaram a expedição do ato, poderá, mediante decisão motivada, ter a autorização ou licença

suspensa ou revogada pelo ICMBio, nos termos da legislação brasileira em vigor.

Este documento não dispensa o cumprimento da legislação que dispõe sobre acesso a componente do patrimônio genético existente no território nacional, na

7 plataforma continental e na zona econômica exclusiva, ou ao conhecimento tradicional associado ao patrimônio genético, para fins de pesquisa científica,

bioprospecção e desenvolvimento tecnológico. Veja maiores informações em www.mma.gov.br/cgen.

8 Em caso de pesquisa em UNIDADE DE CONSERVAÇÃO, o pesquisador titular desta autorização deverá contactar a administração da unidade a fim de CONFIRMAR

8 AS DATAS das expedições, as condições para realização das coletas e de uso da infra-estrutura da unidade.

Outras ressalvas

1 O sangue coletado não deve ultrapassar o equivalente a 1\% da massa corporal da ave. Em coletas consecutivas, não deve ultrapassar $2 \%$ a

1 cada 14 dias. Não deve ser utilizada punção cardíaca e não é recomendado corte de unha (exceto para Trochilidae).

Equipe

\begin{tabular}{|l|l|l|l|l|}
\hline$\#$ & Nome & \multicolumn{1}{|c|}{ Função } & CPF & Doc. Identidade \\
\hline 1 & Fernanda Junqueira Vaz Guida & coleta de amostras & $278.404 .658-38$ & $24.106 .226-3 \mathrm{ssp}-S P$ \\
\hline
\end{tabular}

Este documento (Autorização para atividades com finalidade científica) foi expedido com base na Instrução Normativa nº 03/2014. Através do código de autenticação abaixo, qualquer cidadão poderá verificar a autenticidade ou regularidade deste documento, por meio da página do Sisbio/ICMBio na Internet (www.icmbio.gov.br/sisbio). 


\section{Autorização para atividades com finalidade científica}

\section{Número: 34605-7 \\ Data da Emissão: 27/10/2016 20:54 \\ Data para Revalidação*: 26/11/2017}

* De acordo com o art. 28 da IN 03/2014, esta autorização tem prazo de validade equivalente ao previsto no cronograma de atividades do projeto, mas deverá ser revalidada anualmente mediante a apresentação do relatório de atividades a ser enviado por meio do Sisbio no prazo de até 30 dias a contar da data do aniversário de sua emissão.

Dados do titular

Nome: Karin Kirchgatter

CPF: 127.822.158-17

Título do Projeto: Plasmodium spp. em aves silvestres da Fundação Parque Zoológico de São Paulo: identificação de espécie por microscopia e código de barras de DNA

Nome da Instituição : Superintendência de Controle de Endemias

CNPJ: 43.142.397/0001-69

\begin{tabular}{|l|l|l|l|l|l|}
\hline 2 & Carolina Romeiro Fernandes Chagas & $\begin{array}{l}\text { exames microscópios e } \\
\text { moleculares }\end{array}$ & $324.700 .598-60$ & 330812191 SSP-SP & Brasileira \\
\hline 3 & Regiane Maria Tironi de Menezes & coleta de culicídeos & $065.443 .298-86$ & 122958068 SSP-SP \\
\hline
\end{tabular}

Locais onde as atividades de campo serão executadas

\begin{tabular}{|c|c|l|l|l|}
\hline$\#$ & Município & UF & Descrição do local & Tipo \\
\hline 1 & & SP & Fundação Parque Zoológico de São Paulo \\
\hline
\end{tabular}

Atividades $X$ Táxons

\begin{tabular}{|l|l|l|}
\hline$\#$ & \multicolumn{1}{|c|}{ Atividade } & \\
\hline 1 & Coleta/transporte de amostras biológicas ex situ & Aves \\
\hline 2 & Coleta/transporte de amostras biológicas in situ & Aves \\
\hline 3 & Coleta/transporte de espécimes da fauna silvestre in situ & Culicidae $\left({ }^{\star}\right.$ Qtde: 1000$)$ \\
\hline
\end{tabular}

* Quantidade de indivíduos por espécie, por localidade ou unidade de conservação, a serem coletados durante um ano.

Material e métodos

1 Amostras biológicas (Aves)

\begin{tabular}{l|l} 
Método de captura/coleta (Aves) \\
\hline 2
\end{tabular}

\begin{tabular}{lll}
\hline 3 & Método de captura/coleta (Invertebrados Terrestres)
\end{tabular}

Sangue

Outros métodos de captura/coleta(pelos tA@cnico da FPZSP, seguindo protocolo da instituiA§A£o)

Armadilha luminosa, Outros métodos de captura/coleta(aspirador de Nasci, armadilha de Shannon e

armadilha luminosa CDC mini UV)

Destino do material biológico coletado

\begin{tabular}{|c|c|c|}
\hline$\#$ & Nome local destino & Tipo Destino \\
\hline 1 & FUNDAÇÁO PARQUE ZOOLOGICO DE SÃO PAULO & \\
\hline
\end{tabular}

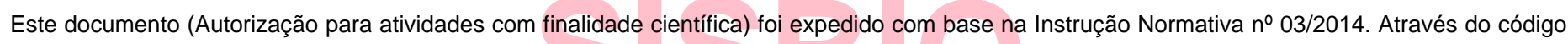
de autenticação abaixo, qualquer cidadão poderá verificar a autenticidade ou regularidade deste documento, por meio da página do Sisbio/ICMBio na Internet (www.icmbio.gov.br/sisbio). 


\section{Autorização para atividades com finalidade científica}

\section{Número: 34605-7 \\ Data da Emissão: 27/10/2016 20:54 \\ Data para Revalidação*: 26/11/2017}

* De acordo com o art. 28 da IN 03/2014, esta autorização tem prazo de validade equivalente ao previsto no cronograma de atividades do projeto, mas deverá ser revalidada anualmente mediante a apresentação do relatório de atividades a ser enviado por meio do Sisbio no prazo de até 30 dias a contar da data do aniversário de sua emissão.

Dados do titular

Nome: Karin Kirchgatter

CPF: $127.822 .158-17$

Título do Projeto: Plasmodium spp. em aves silvestres da Fundação Parque Zoológico de São Paulo: identificação de espécie por microscopia e código de barras de DNA

Nome da Instituição : Superintendência de Controle de Endemias

CNPJ: 43.142.397/0001-69

\section{Registro de coleta imprevista de material biológico}

De acordo com a Instrução Normativa no 03/2014, a coleta imprevista de material biológico ou de substrato não contemplado na autorização ou na licença permanente deverá ser anotada na mesma, em campo específico, por ocasião da coleta, devendo esta coleta imprevista ser comunicada por meio do relatório de atividades. O transporte do material biológico ou do substrato deverá ser acompanhado da autorização ou da licença permanente com a devida anotação. O material biológico coletado de forma imprevista, deverá ser destinado à instituição científica e, depositado, preferencialmente, em coleção biológica científica registrada no Cadastro Nacional de Coleções Biológicas (CCBIO).

\begin{tabular}{|l|l|l|l|l|l|}
\hline Táxon $^{*}$ & Qtde. & Tipo de amostra & Qtde. & Data \\
\hline & & & & \\
\hline & & & & & \\
\hline & & & & & \\
\hline & & & & & \\
\hline & & & & & \\
\hline & & & & & \\
\hline & & & & & \\
\hline & & & & & \\
\hline
\end{tabular}

Este documento (Autorização para atividades com finalidade científica) foi expedido com base na Instrução Normativa nº 03/2014. Através do código de autenticação abaixo, qualquer cidadão poderá verificar a autenticidade ou regularidade deste documento, por meio da página do Sisbio/ICMBio na Internet (www.icmbio.gov.br/sisbio). 


\section{Autorização para atividades com finalidade científica}

Número: 34605-7

Data da Emissão: 27/10/2016 20:54

Data para Revalidação*: 26/11/2017

* De acordo com o art. 28 da IN 03/2014, esta autorização tem prazo de validade equivalente ao previsto no cronograma de atividades do projeto, mas deverá ser revalidada anualmente mediante a apresentação do relatório de atividades a ser enviado por meio do Sisbio no prazo de até 30 dias a contar da data do aniversário de sua emissão.

Dados do titular

Nome: Karin Kirchgatter

CPF: 127.822.158-17

Título do Projeto: Plasmodium spp. em aves silvestres da Fundação Parque Zoológico de São Paulo: identificação de espécie por microscopia e código de barras de DNA

Nome da Instituição : Superintendência de Controle de Endemias CNPJ: $43.142 .397 / 0001-69$

* Identificar o espécime no nível taxonômico possível.

Este documento (Autorização para atividades com finalidade científica) foi expedido com base na Instrução Normativa № 03/2014. Através do código de autenticação abaixo, qualquer cidadão poderá verificar a autenticidade ou regularidade deste documento, por meio da página do Sisbio/ICMBio na Internet (www.icmbio.gov.br/sisbio). 
ANEXO B - Parecer Comitê de Pesquisa do Instituto de Medicina Tropical (CEP/193). 


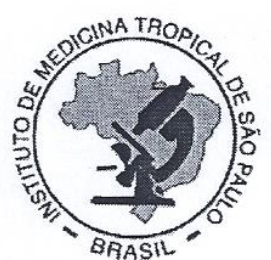

UNIVERSIDADE DE SÃO PAULO

INSTITUTO DE MEDICINA TROPICAL DE SÃO PAULO

COMISSÃO DE PESQUISA E ÉTICA

COMISSÃO DE ÉTICA NO USO DE ANIMAIS EM PESQUISA

Av. Dr. Enéas de Carvalho Aguiar, 470

CEP 05403-000 - São Paulo - Brasil

Telefone:(55-11)3061-8650/7193 e 3064-5132 FAX: (55-11) 3064-5132 e

3062-2174

e-mail:cpq-imt@usp.br

São Paulo, 01 de agosto de 2013.

IImo. (a)

Dra. Karin Kirchgatter

(aos cuidados de Carolina Romeiro Fernandes Chagas)

Em reunião na presente data, a Comissão de Pesquisa e Ética e Comissão de Ética no Uso de Animais em Pesquisa, do Instituto de Medicina Tropical da Universidade de São Paulo, analisou e aprovou, no que diz respeito aos aspectos de natureza da ética em experimentação animal, o projeto de pesquisa classificado sob número CPE-IMT/193 "Plasmodium spp. em aves silvestres da Fundação Parque Zoológico de São Paulo: identificação de espécie por microscopia e código de barras de DNA", sob a sua responsabilidade.

Cabe ao pesquisador elaborar e apresentar à CEUA-IMT, o relatório final sobre a pesquisa, (Lei Procedimentos para o Uso Científico de Animais - Lei n 11.794, 8 de outubro de 2008).

Atenciosamente,

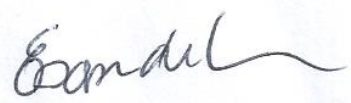

Dr. Expedito José de Albuquerque Luna

Presidente

Comissão de Pesquisa e Ética do IMT-USP<smiles>C=C</smiles>

Dra. Luciana Regina Meireles Jaguaribe Ekman

Coordenadora da Comissão de Ética no Uso de Animais em Pesquisa do IMT-USP 
ANEXO C - Parecer Comitê de Pesquisa do Instituto de Medicina Tropical (CEP/294). 


\section{UNIVERSIDADE DE SÃO PAULO \\ INSTITUTO DE MEDICINA TROPICAL DE SÃO PAULO \\ Av. Dr. Enéas de Carvalho Aguiar, 470 \\ CEP 05403-000 - São Paulo - Brasil - e-mail: cpq-imt@usp.br \\ Telefones: (55) 11-3061-8650, FAX (55) 11-3064-5132}

IImo(a)

Dr(a). Karin Kirchgatter

(aos cuidados de Carolina Romeiro Fernandes Chagas)

Em reunião na presente data, a Comissão de Pesquisa e Ética e Comissão de Ética no Uso de Animais em Pesquisa, do Instituto de Medicina Tropical da Universidade de São Paulo, analisou e APROVOU, no que diz respeito aos aspectos de natureza da ética em experimentação animal, o projeto de pesquisa classificado sob número CPE-IMT/000294A 'Plasmodium spp. em aves silvestres da Fundação Parque Zoológico de São Paulo: identificação de espécie por microscopia e código de barras de DNA', sob a sua responsabilidade.

Cabe ao pesquisador elaborar e apresentar à CEUA-IMT, o relatório final sobre a pesquisa, (Lei Procedimentos para o Uso Científico de Animais - Lei n 11.794, 8 de outubro de 2008).

As seguintes espécies serão utilizadas no projeto:

Ave (0 animais).

Atenciosamente,

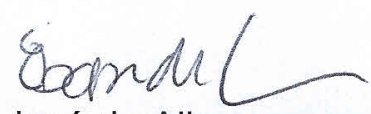

Dr. Expedito José de Albuquerque Luna

Presidente da Comissão de Pesquisa e Ética do IMT-USP

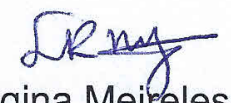

Dra. Luciana Regina Meifeles Jaguaribe Ekman

Coordenadora da Comissão de Ética no Uso de Animais em Pesquisa do IMT-USP 